Florida International University

FIU Digital Commons

FIU Electronic Theses and Dissertations

University Graduate School

$10-17-2018$

\title{
Mapping of the Chromium and Iron Pyrazolate Landscape
}

Jessica Maria Lopez

Florida International University, jlope503@fiu.edu

Follow this and additional works at: https://digitalcommons.fiu.edu/etd

Part of the Inorganic Chemistry Commons

\section{Recommended Citation}

Lopez, Jessica Maria, "Mapping of the Chromium and Iron Pyrazolate Landscape" (2018). FIU Electronic Theses and Dissertations. 3916.

https://digitalcommons.fiu.edu/etd/3916

This work is brought to you for free and open access by the University Graduate School at FIU Digital Commons. It has been accepted for inclusion in FIU Electronic Theses and Dissertations by an authorized administrator of FIU Digital Commons. For more information, please contact dcc@fiu.edu. 


\title{
FLORIDA INTERNATIONAL UNIVERSITY
}

\author{
Miami, Florida
}

MAPPING OF THE CHROMIUM AND IRON PYRAZOLATE LANDSCAPE

A dissertation submitted in partial fulfillment of the

requirements for the degree of

DOCTOR IN PHILOSOPHY

\author{
in \\ CHEMISTRY \\ by \\ Jessica María López Plá
}


To: Dean Michael R. Heithaus

College of Arts, Sciences and Education

This dissertation, written by Jessica María López Plá, and entitled Mapping of the Chromium and Iron Pyrazolate Landscape, having been approved in respect to style and intellectual content, is referred to you for judgment.

We have read this dissertation and recommend that it be approved.

Konstantinos Kavallieratos

$\begin{array}{r}\hline \text { Yuan Liu } \\ \hline \text { Xuewen Wang } \\ \hline \text { Stanislaw Wnuk } \\ \hline \text { Raphael G. Raptis, Major Professor }\end{array}$

Date of Defense: October 17, 2018

The dissertation of Jessica María López Plá is approved.

Dean Michael R. Heithaus

College of Arts, Sciences and Education

Andrés G. Gil

Vice President of Research and Economic Development and Dean of the University Graduate School

Florida International University, 2018 
C Copyright 2018 by Jessica María López Plá

All rights reserved. 


\section{DEDICATION}

I dedicate this dissertation to my family. Without their perseverance, understanding, unconditional support, and most of all love, the completion of this work would not have been possible. 


\section{ACKNOWLEDGMENTS}

First, I would like to thank my advisor Professor Raphael G. Raptis. This work would have not been possible without his expertise and vast knowledge. Even with many tall walls on the path, he never gave up on my ability to complete this task. His patience and motivation helped me persevere and strive for the best. I am honored to have such a prominent and professional advisor.

Also, I wish to thank the members of my committee: Prof. Konstantinos Kavallieratos, Prof. Yuan Liu, Prof. Xuewen Wang and Prof. Stanislaw Wnuk, for their advice, support and patience. Their advice and guidance has been most appreciated. I would also like to thank them for investing their time and providing valuable feedback when I needed it the most.

I would like to thank our collaborators and group members that one way or another impacted this work: Prof. Christopher Dares (Florida International University, Miami, FL; Spectroelectrochemistry experiment), Prof. Joshua Telser (Roosevelt University, Chicago, IL; X-band EPR) and Dr. Athanasios K. Boudalis (Univ. Strasbourg, France; Q-band EPR), Dr. Yiannis Sanakis (National Center for Scientific Research Demokritos, Greece; Mössbauer measurements).

I would like to thank Raphael G. Raptis' research group, their advice and constant support was precious. These amazing people have become my family away from home: Dr. Logesh Mathivathanan, Dr. Indranil Chakraborty, Dr. Evgen Govor, Dr. Alan Rodriguez, Dr. Kaige Shi, Shambhu Kandel, David Kreiger and Konstantinos Lazarou. Thank you for sharing your experiences and expertise. 
Last, but not least, I would like to thank my parents and sister for their unconditional love and support. Since the beginning of this journey, you were always cheering for me and giving me strength. I feel so blessed to have such a wonderful family. Even if we are far, our hearts will always be together. 
ABSTRACT OF DISSERTATION

MAPPING OF THE CHROMIUM AND IRON PYRAZOLATE LANDSCAPE

by

Jessica María López Plá

Florida International University, 2018

Miami, Florida

Professor Raphael G. Raptis, Major Professor

The main objective of this project is to synthesize the first family of polynuclear chromium pyrazolate complexes. Complexity in analysis of the experimental magnetic data of multinuclear complexes arises from their $(2 \mathrm{~S}+1)^{\mathrm{N}}$ microstates, where $\mathrm{S}$ is the spin of each metal center and $\mathrm{N}$ is the number of metal centers. For example, high-spin (HS)$\mathrm{Fe}_{3}^{\mathrm{III}}{ }_{3}$ has 216 microstates and $\mathrm{HS}-\mathrm{Fe}^{\mathrm{III}}{ }_{8} \approx 1.7 \times 10^{6}$ microstates $(\mathrm{S}=5 / 2)$. However, complexes with chromium(III) $\mathrm{S}=3 / 2$ will have a noticeable reduction of microstates. Mononuclear complexes with formula $\left[m e r-\mathrm{CrCl}_{3}\left(\mathrm{pzH}^{*}\right)_{3}\right](\mathrm{pz} * \mathrm{H}=$ pyrazole, 3-Me-pzH, 4-Me-pzH, 4-Cl-pzH, 4-I-pzH, 4-Br-pzH) and $\left[\right.$ trans- $\left.\mathrm{CrCl}_{2}\left(\mathrm{pzH}^{*}\right)_{4}\right] \mathrm{Cl}\left(\mathrm{pzH}^{*}=\right.$ pyrazole and 3-Me-pzH) were synthesized and thoroughly characterized. Polynuclear iron pyrazolate complexes are prepared by the addition of base to $\left[m e r-\mathrm{FeCl}_{3}\left(\mathrm{pzH}^{*}\right)_{3}\right]$ and $\left[\right.$ trans $\left.-\mathrm{FeCl}_{2}\left(\mathrm{pzH}^{*}\right)_{4}\right] \mathrm{Cl}$ complexes; the path is not paralleled by mononuclear chromium(III) pyrazole complexes. There is a challenging situation with these reactions, caused by the attainment of equilibrium, where the stable mononuclear complexes and traces of dinuclear species coexist in solution. Microwave assisted reaction of $\mathrm{Cr}\left(\mathrm{NO}_{3}\right)_{3} \cdot 9 \mathrm{H}_{2} \mathrm{O}$ and pyrazole ligand in dimethylformamide (DMF) solution afforded redox inactive trinuclear formate-pyrazolate mixed-ligand complexes with formula 
$\left[\mathrm{Cr}_{3}\left(\mu_{3}-\mathrm{O}\right)\left(\mu-\mathrm{O}_{2} \mathrm{CH}\right)_{3}(\mu-4-\mathrm{R}-\mathrm{pz})_{3}(\mathrm{DMF})_{3}\right]^{+}(\mathrm{pz}=$ pyrazolate anion; $\mathrm{R}=\mathrm{H}, \mathrm{Me}, \mathrm{Cl})$. Thermally assisted synthesis with non-hydrolysable solvent yielded an electrochemically active all-pyrazolate complex. Complex with formula $\left(\mathrm{Ph}_{4} \mathrm{P}\right)_{2}\left[\mathrm{Cr}_{3}\left(\mu_{3}-\mathrm{O}\right)(\mu-4-\mathrm{Cl}-\mathrm{pz})_{6} \mathrm{Cl}_{3}\right]$ and $\left(\mathrm{Ph}_{4} \mathrm{P}\right)_{2}\left[\mathrm{Cr}_{3}\left(\mu_{3}-\mathrm{O}\right)(\mu-4-\mathrm{Cl}-\mathrm{pz})_{6} \mathrm{Br}_{3}\right]$ have an oxidation process at $0.502 \mathrm{~V}$ at $0.332 \mathrm{~V}$, respectively. The latter has a second accessed oxidation process at $0.584 \mathrm{~V}$. These systems are the first example of electrochemically amendable trinuclear pyrazolate complex with $\left\{\mathrm{Cr}_{3} \mathrm{O}\right\}$ core.

The all-ferric complexes $\left[\mathrm{Fe}_{3}\left(\mu_{3}-\mathrm{O}\right)\left(\mu-4-\mathrm{NO}_{2}-\mathrm{pz}\right)_{6}(\mathrm{~L})_{3}\right]^{2-}\left(\mathrm{L}=\mathrm{NCO}^{-}, \mathrm{N}_{3}\right)$ were synthesized from reaction of $\left[\mathrm{Fe}_{3}\left(\mu_{3}-\mathrm{O}\right)\left(\mu-4-\mathrm{NO}_{2}-\mathrm{pz}\right)_{6} \mathrm{Cl}_{3}\right]^{2-}$ with $\mathrm{NaNCO}$ and $\mathrm{NaN}_{3}$. Expected reversible reduction processes were observed for both complexes at more negative potential, $-0.70 \mathrm{~V}$, compared to the thiocyanate complex $(-0.36 \mathrm{~V})$. The ${ }^{57} \mathrm{Fe}$ Mössbauer of the reduced $\left[\mathrm{Fe}_{3}\left(\mu_{3}-\mathrm{O}\right)\left(\mu-4-\mathrm{NO}_{2}-\mathrm{pz}\right)_{6}\left(\mathrm{~N}_{3}\right)_{3}\right]^{3-}$ is suggestive of a HS-to-LS electronic reorganization, as seen for the $\left[\mathrm{Fe}_{3}\left(\mu_{3}-\mathrm{O}\right)\left(\mu-4-\mathrm{NO}_{2}-\mathrm{pz}\right)_{6}(\mathrm{SCN})_{3}\right]^{3-}$ complex. Furthermore, compound $\left[\mathrm{Fe}_{3}\left(\mu_{3}-\mathrm{O}\right)\left(\mu-4-\mathrm{NO}_{2}-\mathrm{pz}\right)_{6}\left(\mathrm{~N}_{3}\right)_{3}\right]^{2-}$, shows a unique reversible oxidation process at $0.82 \mathrm{~V}\left(v s . \mathrm{Fc}^{+} / \mathrm{Fc}\right)$ to a mixed-valent, formally $\mathrm{Fe}^{3+}{ }_{2} / \mathrm{Fe}^{4+}$ species. 


\section{TABLE OF CONTENTS}

CHAPTER

PAGE

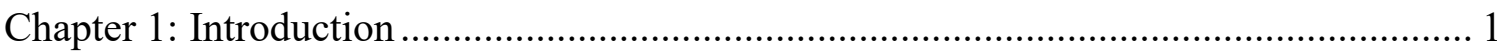

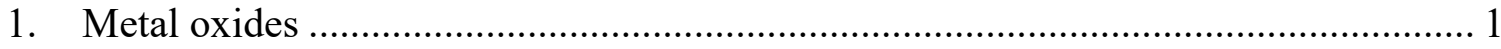

1.1. Metal oxides in biological systems …………………............................... 1

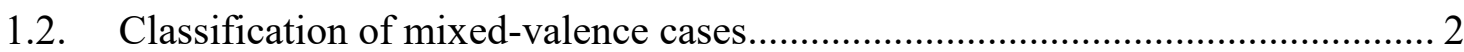

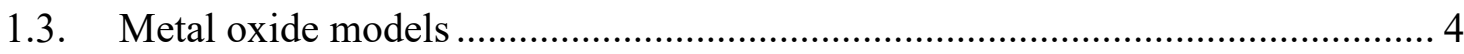

1.4. Iron complexes as active site models ............................................................. 4

1.5. Polynuclear complexes of interest.............................................................. 5

1.5.1. Trinuclear carboxylate and pyrazolate complexes........................................ 7

1.5.2. Octanuclear carboxylate and pyrazolate complexes ..................................... 10

1.5.3. Dinuclear carboxylate and pyrazolate complexes....................................... 14

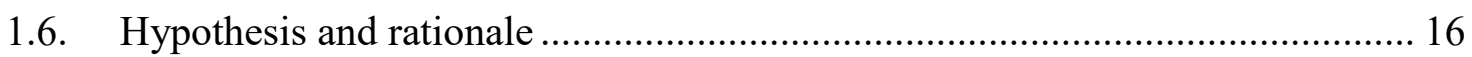

Chapter 2: Chromium pyrazole/pyrazolate complexes................................................ 20

2. Synthesis of mononuclear chromium pyrazole complexes ........................................ 20

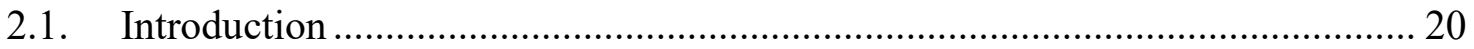

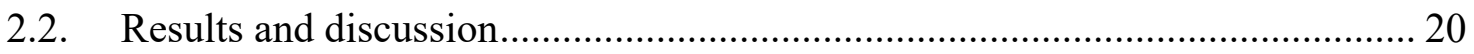

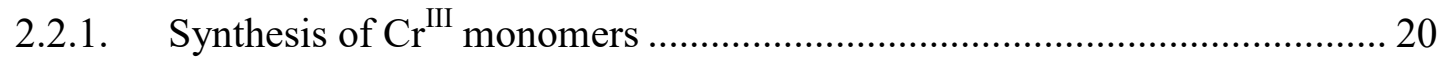

2.2.2. Crystallographic description of $\mathrm{Cr}^{\mathrm{III}}$ monomers ........................................ 21

2.2.3. Electrochemistry and electronic absorption spectra of $\mathrm{Cr}^{\mathrm{III}}$ monomers...... 31

2.2.4. Nuclear magnetic resonance and electron paramagnetic resonance ........... 34

2.2.4.1. Nuclear magnetic resonance of $\mathrm{Cr}^{\mathrm{III}}$ monomers .................................. 35

2.2.4.2. Electronic paramagnetic resonance of $\mathrm{Cr}^{\mathrm{III}}$ monomers ....................... 42

2.2.5. Base addition to mononuclear $\mathrm{Cr}^{\mathrm{III}}$ pyrazole complexes ............................. 46

2.2.6. Other products from mononuclear $\mathrm{Cr}^{\mathrm{III}}$ pyrazole syntheses ....................... 47

2.2.6.1. Crystallographic description of trinuclear and dinuclear complexes .. 51

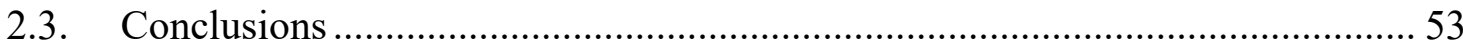

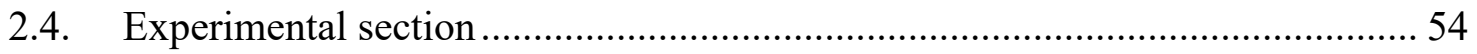

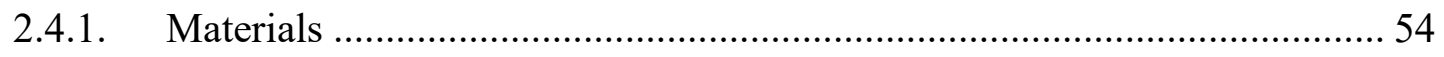




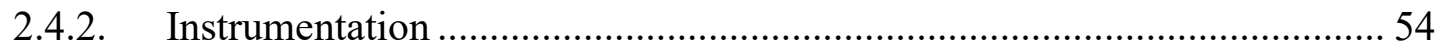

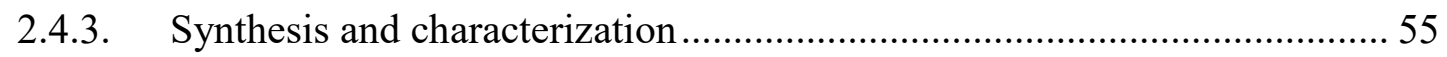

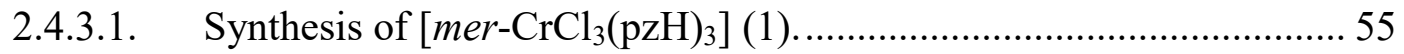

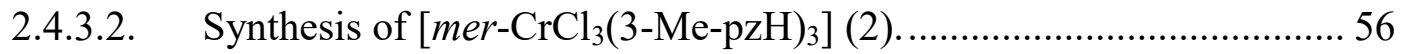

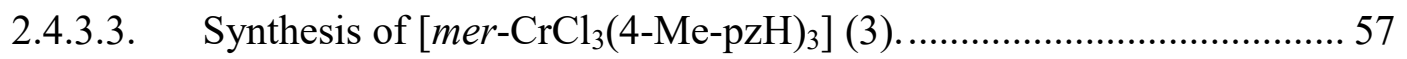

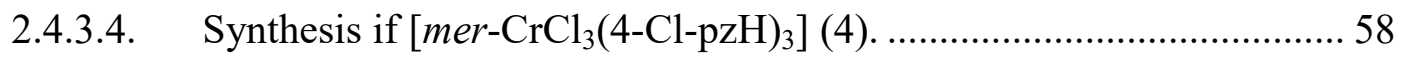

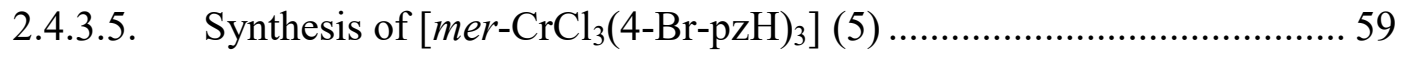

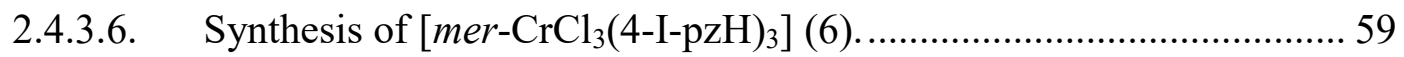

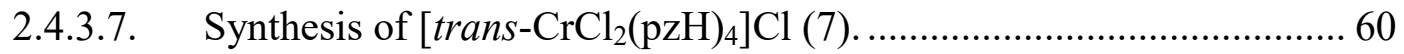

2.4.4. Crystal structure and structure refinement data ........................................... 60

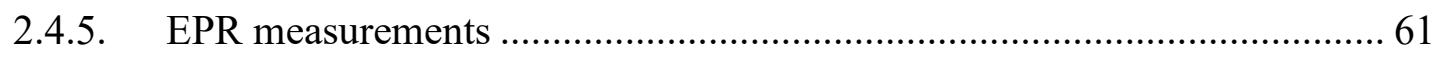

Chapter 3: Chromium mixed-ligand complexes with $\mathrm{Cr}_{3}\left(\mu_{3}-\mathrm{O}\right)$ cores .............................. 65

3. Synthesis of trinuclear chromium mixed-ligand formate-pyrazolate complexes...... 65

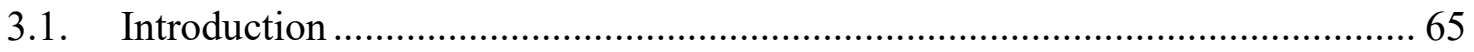

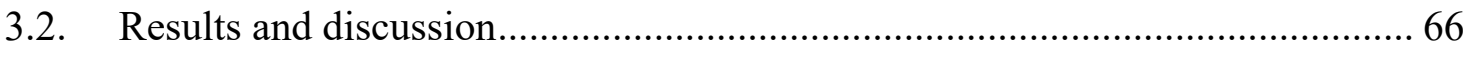

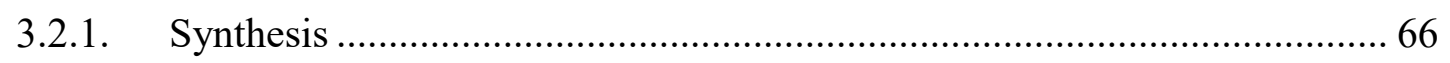

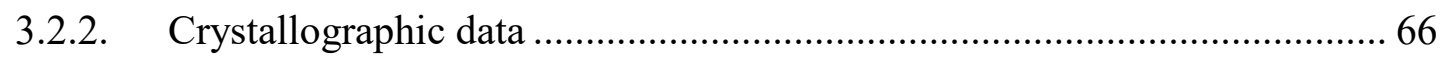

3.2.3. Electrochemistry and absorption spectra ………..................................... 71

3.2.4. Nuclear magnetic resonance ................................................................. 72

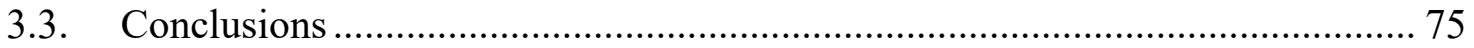

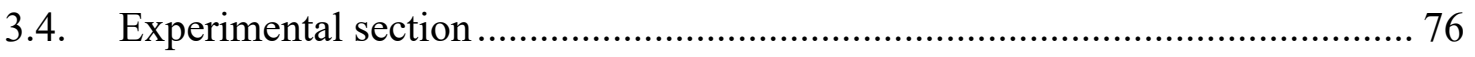

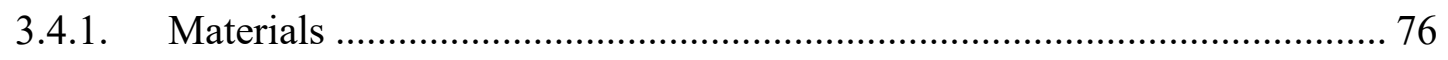

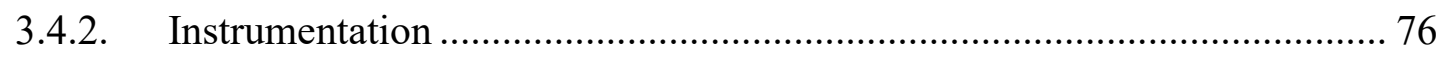

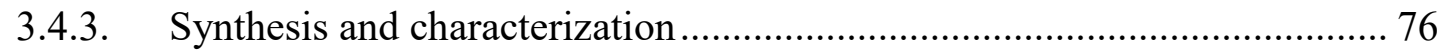

3.4.3.1. Synthesis of $\left[\mathrm{Cr}_{3}\left(\mu_{3}-\mathrm{O}\right)\left(\mu-\mathrm{O}_{2} \mathrm{CH}\right)_{3}(\mu-4-\mathrm{Me}-\mathrm{pz})_{3}(\mathrm{DMF})_{3}\right] \mathrm{PF}_{6}(14) \ldots . . .76$

3.4.3.2. Synthesis of $\left[\mathrm{Cr}_{3}\left(\mu_{3}-\mathrm{O}\right)\left(\mu-\mathrm{O}_{2} \mathrm{CH}\right)_{3}(\mu-\mathrm{pz})_{3}(\mathrm{DMF})_{3}\right] \mathrm{PF}_{6}(15) \ldots \ldots \ldots \ldots \ldots . . . . .77$

3.4.3.3. Synthesis of $\left[\mathrm{Cr}_{3}\left(\mu_{3}-\mathrm{O}\right)\left(\mu-\mathrm{O}_{2} \mathrm{CH}\right)_{3}(\mu-4-\mathrm{Cl}-\mathrm{pz})_{3}(\mathrm{DMF})_{3}\right] \mathrm{PF}_{6}(16) \ldots \ldots . .77$

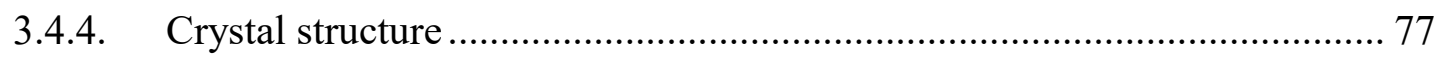


Chapter 4: Chromium pyrazolate complexes with $\mathrm{Cr}_{3}\left(\mu_{3}-\mathrm{O}\right)$ cores .............................. 79

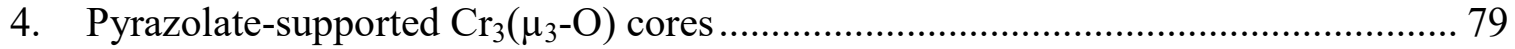

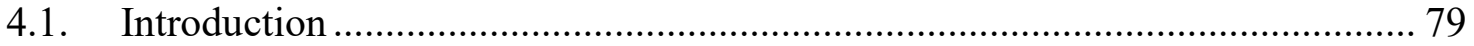

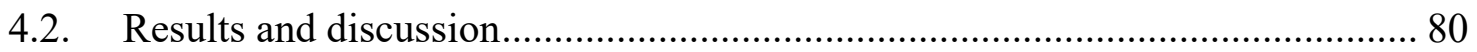

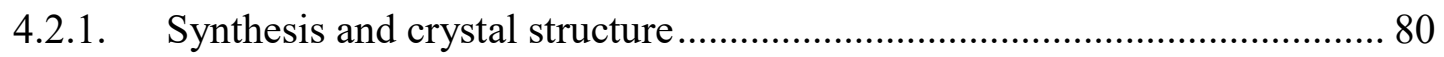

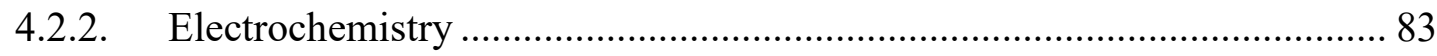

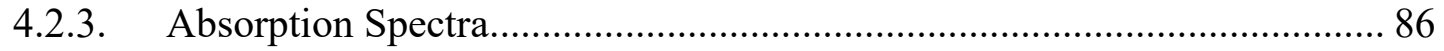

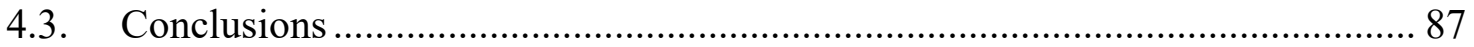

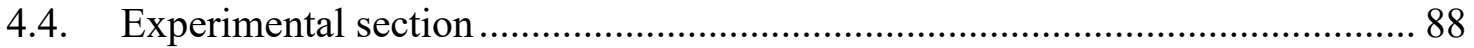

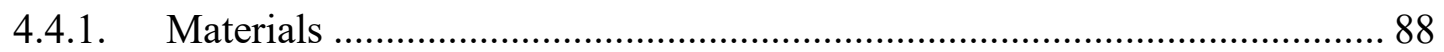

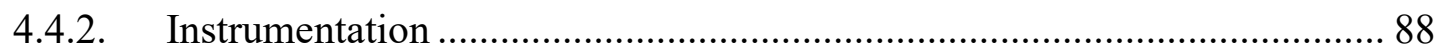

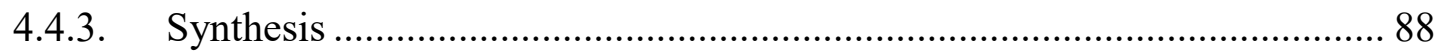

4.4.3.1. Synthesis of $\left(\mathrm{Ph}_{4} \mathrm{P}\right)_{2}\left[\mathrm{Cr}_{3}\left(\mu_{3}-\mathrm{O}\right)(\mu-4-\mathrm{Cl}-\mathrm{pz})_{6} \mathrm{Cl}_{3}\right](17) \ldots \ldots \ldots \ldots \ldots \ldots \ldots \ldots . . . . . . . . . . . .68$

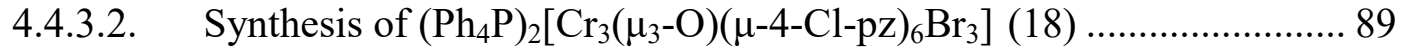

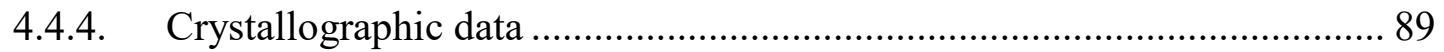

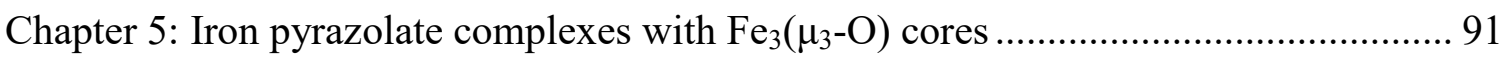

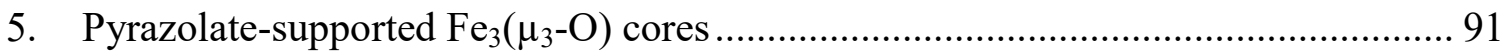

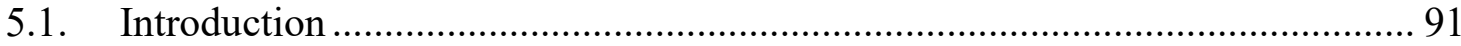

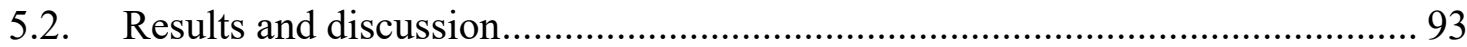

5.2.1. Synthesis and crystal structure description ......................................... 93

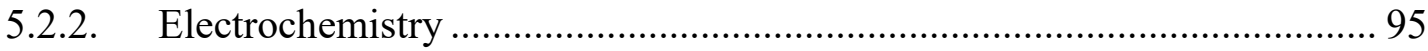

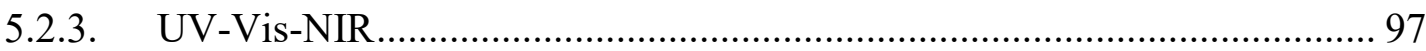

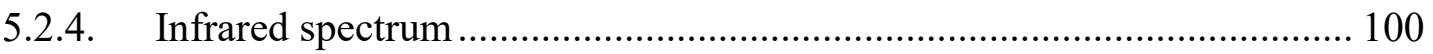

5.2.5. Nuclear magnetic resonance .............................................................. 101

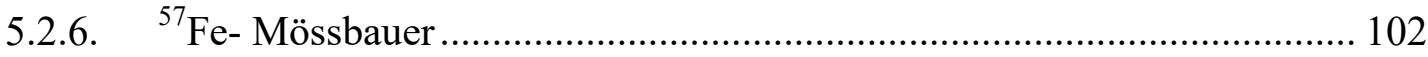

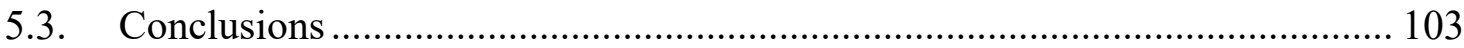

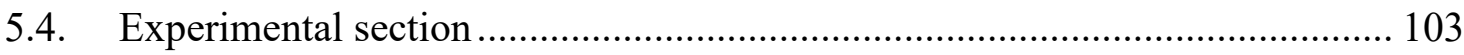

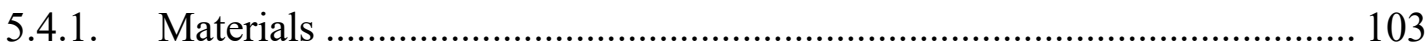

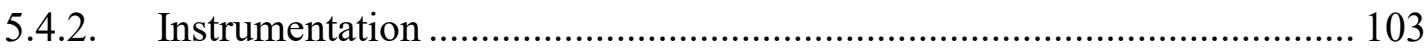

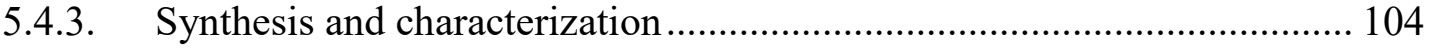

5.4.3.1. Synthesis of $(\mathrm{TBA})_{2}\left[\mathrm{Fe}_{3}\left(\mu_{3}-\mathrm{O}\right)\left(4-\mathrm{NO}_{2}-\mathrm{pz}\right)_{6}(\mathrm{NCO})_{3}\right](19) \ldots \ldots \ldots \ldots \ldots . . . . .104$ 
5.4.3.2. Synthesis of $(\mathrm{TBA})_{2}\left[\mathrm{Fe}_{3}\left(\mu_{3}-\mathrm{O}\right)\left(4-\mathrm{NO}_{2}-\mathrm{pz}\right)_{6}\left(\mathrm{~N}_{3}\right)_{3}\right](20) \ldots \ldots \ldots \ldots \ldots \ldots . . . . . . . . .104$

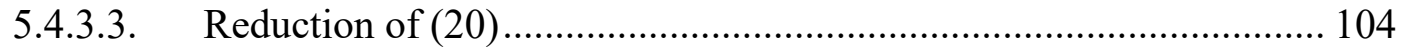

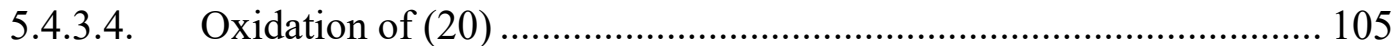

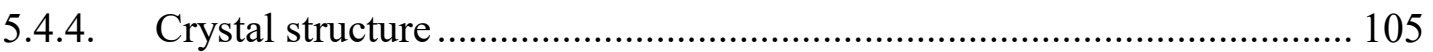

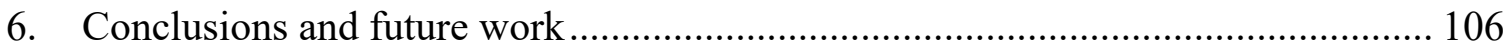

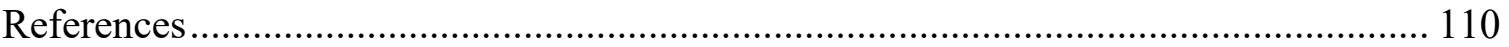

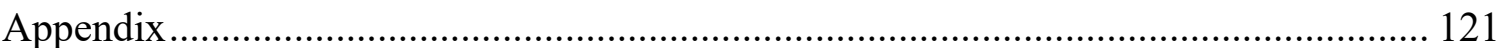

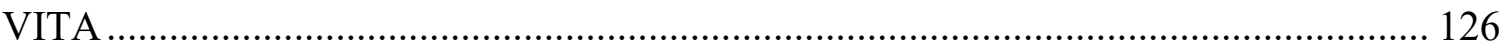




\section{LIST OF TABLES}

TABLE

PAGE

Table 1. Identified and characterized diiron metalloproteins. Modified from Tshuva et $a l{ }^{17}$ 5

Table 2. M $\cdots M$ distances $(\AA)$ for pyrazolate and the analogous carboxylate complexes. . 8

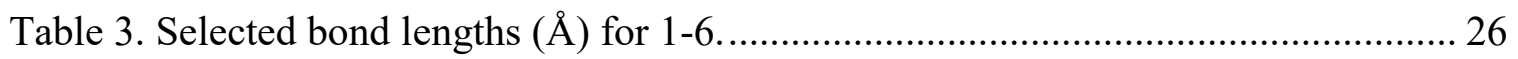

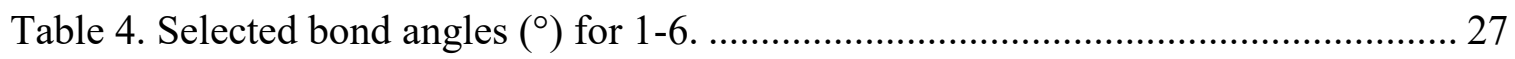

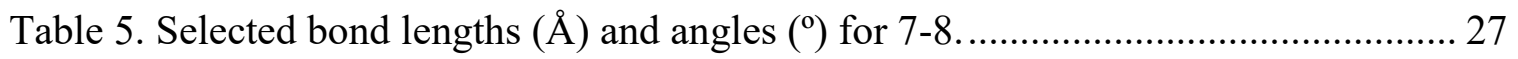

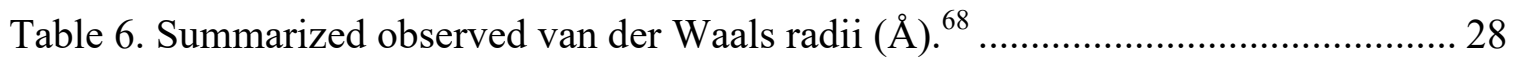

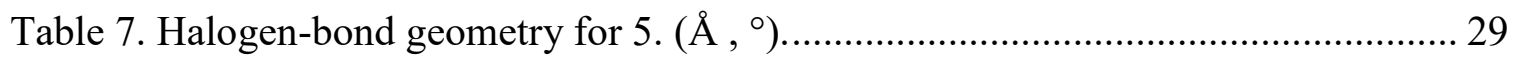

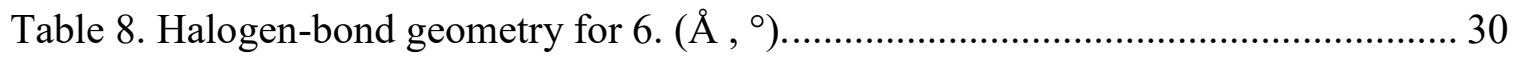

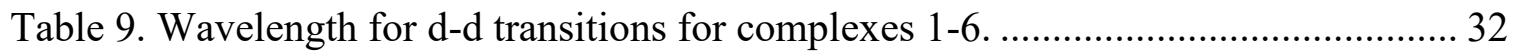

Table 10. Best-fit parameters for the Q-band EPR spectra of complexes. ...................... 44

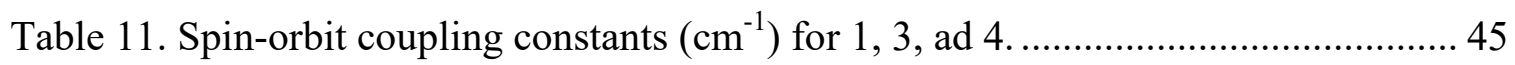

Table 12. Selected bond lengths $(\AA)$ and angles $\left(^{\circ}\right)$ for dinuclear chromium pyrazolate

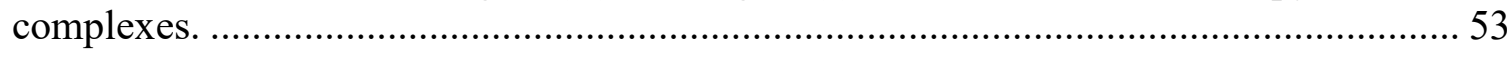

Table 13. Bond lengths $(\AA)$ and angles $\left(^{\circ}\right)$ for selected $\mathrm{Cr}^{\mathrm{III}}$ carboxylate complexes ...... 53

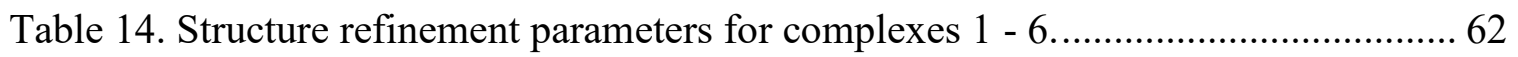

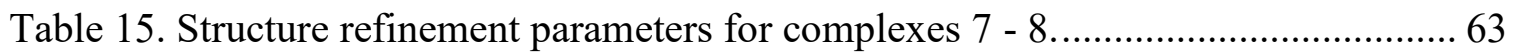

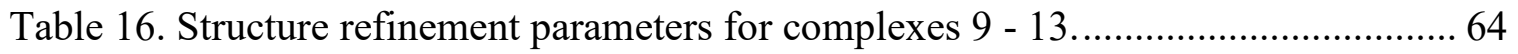


Table 17. Selected interatomic distances $(\AA)$ for complexes 14 - 16.

Table 18. $\mathrm{Cr} \cdots \mathrm{Cr}$ distances $(\AA)$ and angles $\left(^{\circ}\right)$ for selected trinuclear chromium carboxylate complexes.

Table 19. Electronic absorption spectral $\left(\mathrm{cm}^{-1}\right)$ data for trinuclear mixed-ligand acetate

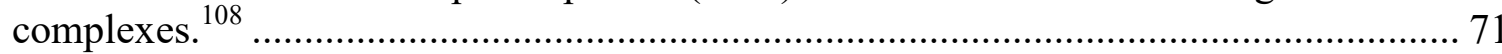

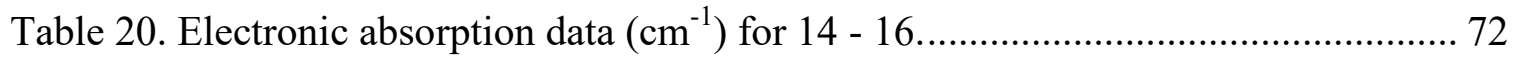

Table 21. ${ }^{1} \mathrm{H}$ NMR chemical shifts for complexes 14,15 , and 16 in ppm. .................... 73

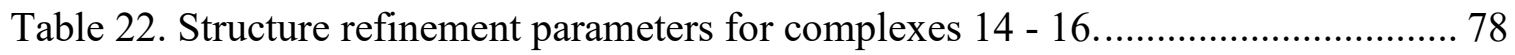

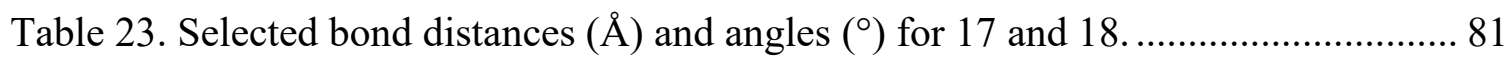

Table 24. $\mathrm{Cr} \cdots \mathrm{Cr}(\AA)$ distance for selected all-carboxylate chromium complexes......... 82

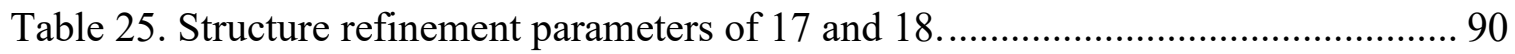

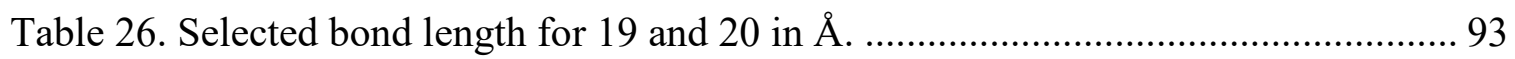

Table 27. IR stretch frequency $\left(\mathrm{cm}^{-1}\right)$ of coordinated azide ligands.......................... 100

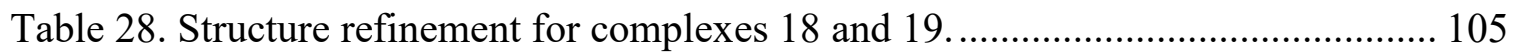




\section{LIST OF FIGURES}

FIGURE

PAGE

Figure 1. Reduction and oxidation mechanism in the $\mathrm{Fe}_{4} \mathrm{~S}_{4}$-unit of ferredoxins. ${ }^{8}$ 2

Figure 2. Potential energy diagram for Class I, Class II and Class III species according to the Robin-Day Scheme. Modified from reference ${ }^{11}$ 3

Figure 3. Active site of hemerythrin (left) and its synthetic model (right). ${ }^{17}$ 4

Figure 4. Trinuclear $\mathrm{Pd}^{\mathrm{II}}$ complexes with $\mu-\mathrm{pz}$ (left) and $\mu-\mathrm{O}_{2} \mathrm{CR}$ (right) ligands. ${ }^{29,36} \ldots \ldots .8$

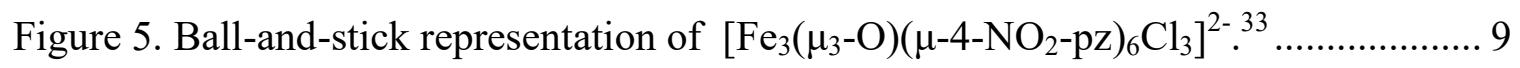

Figure 6. Cyclic voltammogram of $(\mathrm{TBA})_{2}\left[\mathrm{Fe}_{3}\left(\mu_{3}-\mathrm{O}\right)\left(\mu-4-\mathrm{NO}_{2}-\mathrm{pz}\right)_{6} \mathrm{Cl}_{3}\right] v s . \mathrm{Fc}^{+} / \mathrm{Fc}^{33} \ldots .9$

Figure 7. Structure of $\left[\mathrm{Cr}_{8}\left(\mu_{4}-\mathrm{O}\right)_{4}\left(\mu-\mathrm{O}_{2} \mathrm{CPh}\right)_{12}\left(\mathrm{O}_{2} \mathrm{CPh}\right)_{4}\right]$. H-atoms are omitted for clarity. $\left(\mathrm{Cr}\right.$, pink; $\mathrm{O}$, red; $\mathrm{C}$, black) ${ }^{39}$ 10

Figure 8. Ball-and-stick representation of $\left[\mathrm{Fe}^{\mathrm{III}}{ }_{8}\left(\mu_{4}-\mathrm{O}\right)_{4}(\mu-\mathrm{pz})_{12} \mathrm{Cl}_{4}\right](\mathrm{Fe}$, brown; $\mathrm{Cl}$, green; O, red; N, blue; C, black). ${ }^{40}$

Figure 9. Structure of $\mathrm{Fe}_{8} \mathrm{O}_{4}$ core of the $\left[\mathrm{Fe}^{\mathrm{III}}{ }_{8}\left(\mu_{4}-\mathrm{O}\right)_{4}\left(\mu-\mathrm{pz}^{*}\right)_{12} \mathrm{X}_{4}\right]$

Figure 10. Cyclic voltamogram of $\left[\mathrm{Fe}^{\mathrm{III}}{ }_{8}\left(\mu_{4}-\mathrm{O}\right)_{4}(\mu-\mathrm{pz})_{12} \mathrm{Br}_{4}\right]$ in $0.5 \mathrm{M} \mathrm{TBAPF}_{6} / \mathrm{DCM}$,

Pt-disk working electrode, $v s . \mathrm{Fc}^{+} / \mathrm{Fc}$. Reproduced from Baran et al. ${ }^{40}$ 13

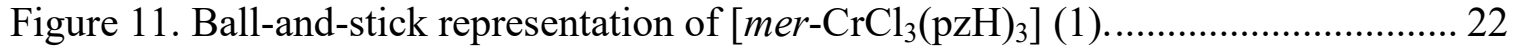

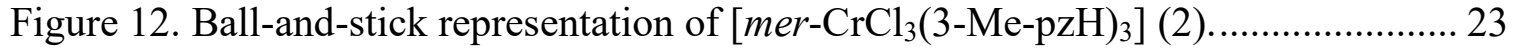

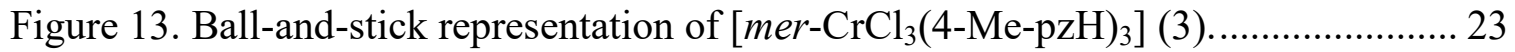

Figure 14. Ball-and-stick representation of $\left[\right.$ mer- $\left.\mathrm{CrCl}_{3}(4-\mathrm{Cl}-\mathrm{pzH})_{3}\right](4), \ldots \ldots \ldots \ldots \ldots \ldots \ldots . . . . . . . . . .24$

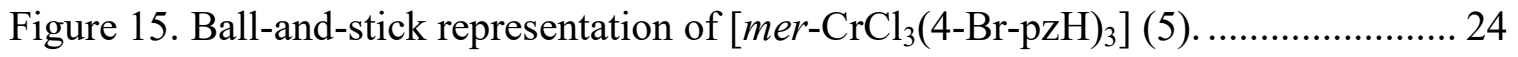

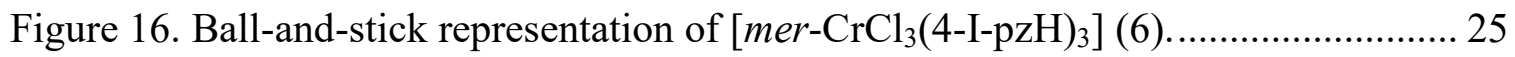


Figure 17. Ball-and-stick representation of $\left[\text { trans }-\mathrm{CrCl}_{2}(\mathrm{pzH})_{4}\right]^{+}(7)$ cation. Chloride counter ion is omitted...

Figure 18. Ball-and-stick representation of $\left[\text { trans- } \mathrm{CrCl}_{2}(3-\mathrm{Me}-\mathrm{pzH})_{4}\right]^{+}(8)$ cation.

Chloride counter ion is omitted. 26

Figure 19. Illustration of halogen bonding between $\mathrm{Cl}$ atoms on complex 4 ................. 28

Figure 20. Illustration of crystal packing of 5, showing 1D chains linked by halogen bonding.

Figure 21. Illustration of crystal packing of 5, showing two 1D chains linked by halogen bonding. 30

Figure 22. Illustration of crystal packing of 6 , showing halogen bonding. THF solvent molecule and hydrogen atoms were omitted for clarity. 31

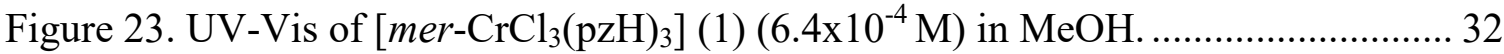

Figure 24. Dielectric constant $\left(\mathrm{Fm}^{-1}\right)$ of solvent as a function of charge transfer (CT) band energy $\left(\mathrm{cm}^{-1}\right)$ for complex 1 34

Figure 25. ${ }^{1} \mathrm{H}$ NMR of complex 1 (red) and 3 (green) in Acetonitrile- $\mathrm{d}_{3}$ at $400 \mathrm{MHz}$. Spectra was referenced to the residual solvent proton resonance.................................. 36

Figure 26. ${ }^{1} \mathrm{H}$ NMR of complex 1 (purple), 3 (blue), 4 (green), 5 (orange) and 6 (red) in Acetonitrile- $\mathrm{d}_{3}(\mathrm{red})$ at $400 \mathrm{MHz}$. 37

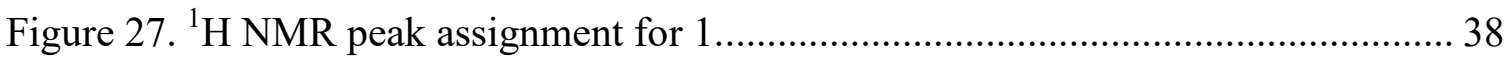

Figure 28. Variable temperature $400 \mathrm{MHz}{ }^{1} \mathrm{H}$ NMR of complex 1 in acetone- $\mathrm{d}_{6} \ldots \ldots \ldots . . . . .39$

Figure 29. Temperature dependence of $\mathrm{H}$ chemical shifts of complex 1..................... 39

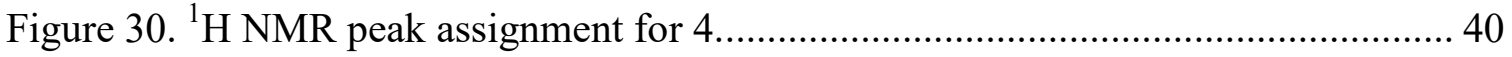

Figure 31. Variable temperature $\left(-50\right.$ to $\left.+23{ }^{\circ} \mathrm{C}\right) 400 \mathrm{MHz}{ }^{1} \mathrm{H}$ NMR of complex 4 in

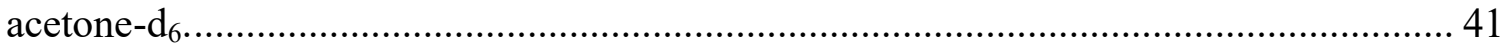

Figure 32. Temperature dependence of $\mathrm{H}$ chemical shifts of complex 4 . ...................... 41 
Figure 33. X-Band EPR of 1 (red) and 4 (green) $(9.376 \mathrm{GHz}), 10 \mathrm{~K}$

Figure 34. Q-band EPR experimental (black lines) and calculated (red lines) spectra of frozen MeCN solutions. The insets show the distribution of the $D$ parameter. 44

Figure 35. Time-dependant UV-Vis spectra for the reaction of $\left[\right.$ mer- $\left.\mathrm{CrCl}_{3}(\mathrm{pzH})_{3}\right](1)$ with triethylamine in acetonitrile. 46

Figure 36. Ball and stick representation of $\left[\mathrm{Cr}_{3}^{\mathrm{III}}\left(\mu_{3}-\mathrm{O}\right)(\mu-\mathrm{OH})_{3}(3-\mathrm{Me}-\mathrm{pzH})_{9}\right] \mathrm{Cl}_{4}(9)$.

Some hydrogen atoms are omitted for clarity.

Figure 37. Ball and stick representation of $\left[\mathrm{Cr}^{\mathrm{III}}{ }_{2}(\mu-\mathrm{OH})(\mu-4-\mathrm{Me}-\mathrm{pz})(4-\mathrm{Me}-\mathrm{pzH})_{4} \mathrm{Cl}_{4}\right]$

(10) Dashed red lines represent H-bonds. 48

Figure 38. Ball and stick representation of $\left[\mathrm{Cr}^{\mathrm{III}}{ }_{2}(\mu-\mathrm{OH})(\mu-4-\mathrm{Me}-\mathrm{pz})_{2}(4-\mathrm{Me}-\right.$ $\left.\mathrm{pzH})_{4} \mathrm{Cl}_{2}\right] \mathrm{Cl}$ (11). Dashed red lines represent H-bonds.

Figure 39. Ball and stick representation of $\left[\mathrm{Cr}_{2}^{\mathrm{III}}{ }_{2}(\mu-\mathrm{OH})(\mu-\mathrm{pz})_{2}(\mathrm{pzH})_{4} \mathrm{Cl}_{2}\right] \mathrm{Cl}(12)$.

Dashed red lines represent H-bonds. 50

Figure 40. Ball and stick representation of $\left[\mathrm{Cr}^{\mathrm{III}}{ }_{2}(\mu-\mathrm{OH})(\mu-4-\mathrm{Cl}-\mathrm{pz})_{2}(4-\mathrm{Cl}-\mathrm{pzH})_{4} \mathrm{Cl}_{2}\right] \mathrm{Cl}$ (13). Dashed red lines represent H-bonds. 50

Figure 41. Ball and stick representation structure of $\left[\mathrm{Cr}_{3}^{\mathrm{III}}{ }_{3}\left(\mu_{3}-\mathrm{O}\right)(\mu-4-\mathrm{Me}-\mathrm{pz})_{3}(\mu-\right.$ $\left.\left.\mathrm{O}_{2} \mathrm{CH}\right)_{3}(\mathrm{DMF})_{3}\right]^{+}(14)$.

Figure 42. Ball and stick representation structure of $\left[\mathrm{Cr}_{3}^{\mathrm{III}}\left(\mu_{3}-\mathrm{O}\right)(\mu-\mathrm{pz})_{3}(\mu-\right.$ $\left.\left.\mathrm{O}_{2} \mathrm{CH}\right)_{3}(\mathrm{DMF})_{3}\right]^{+}(15)$.

Figure 43. Ball and stick representation structure of $\left[\mathrm{Cr}_{3}^{\mathrm{III}}\left(\mu_{3}-\mathrm{O}\right)(\mu-4-\mathrm{Cl}-\mathrm{pz})_{3}(\mu-\right.$ $\left.\left.\mathrm{O}_{2} \mathrm{CH}\right)_{3}(\mathrm{DMF})_{3}\right]^{+}(16)$ 70

Figure 44. ${ }^{1} \mathrm{H}$ NMR of complex 16 in $\mathrm{CDCl}_{3}$ at $400 \mathrm{MHz}$. Spectrum referenced to the residual solvent proton resonance.

Figure 45. ${ }^{1} \mathrm{H}$ NMR of complex 14 (top) and 15 (bottom) in $\mathrm{CDCl}_{3}$ at $400 \mathrm{MHz}$. Spectra referenced to the residual solvent proton resonance.

Figure 46. Ball-and-stick representation $\left[\mathrm{Cr}_{3}\left(\mu_{3}-\mathrm{O}\right)(\mu-4-\mathrm{Cl}-\mathrm{pz})_{6} \mathrm{Cl}_{3}\right]^{-2}(17)$. Counter ions are omitted for clarity. 
Figure 47. Ball-and-stick representation $\left[\mathrm{Cr}_{3}\left(\mu_{3}-\mathrm{O}\right)(\mu-4-\mathrm{Cl}-\mathrm{pz})_{6} \mathrm{Br}_{3}\right]^{-2}(18)$. Counter ions are omitted for clarity.

Figure 48. Differential Pulse Voltammogram (DPV) (blue) and Cyclic Voltammogram (CV) (green) of $17 v s . \mathrm{Fc}^{+} / \mathrm{Fc}$. $\left[\mathrm{Cr}_{3}\right]^{1-2-}\left(\mathrm{E}_{1 / 2}=0.502 \mathrm{~V}\right) .150 \mathrm{mV} / \mathrm{s}$ sweep. 84

Figure 49. Differential Pulse Voltammogram (DPV) (blue) and Cyclic Voltammogram (CV) (red) of $18 v s . \mathrm{Fc}^{+} / \mathrm{Fc}$. $\left[\mathrm{Cr}_{3}\right]^{1-/ 2-}\left(\mathrm{E}_{1 / 2}=0.332 \mathrm{~V}\right),\left[\mathrm{Cr}_{3}\right]^{1 / / 0}\left(\mathrm{E}_{1 / 2}=0.584 \mathrm{~V}\right) \ldots \ldots \ldots \ldots \ldots . .85$

Figure 50. CV (red) and DPV (forward, blue; reverse, green) of 18 ............................. 86

Figure 51. UV-VIS spectra for 17 and 18 in DCM....................................................... 87

Figure 52. Ball-and-stick representation of $\left[\mathrm{Fe}_{3}\left(\mu_{3}-\mathrm{O}\right)\left(4-\mathrm{NO}_{2}-\mathrm{pz}\right)_{6}(\mathrm{SCN})_{3}\right]^{2-} \ldots \ldots \ldots \ldots \ldots . . . . . . . .92$

Figure 53. ${ }^{57} \mathrm{Fe}-$ Mössbauer spectra of the all ferric of $\left[\mathrm{Fe}_{3}\left(\mu_{3}-\mathrm{O}\right)\left(4-\mathrm{NO}_{2}-\mathrm{pz}\right)_{6}(\mathrm{SCN})_{3}\right]^{2-}$ (top) and the one electron reduced of $\left[\mathrm{Fe}_{3}\left(\mu_{3}-\mathrm{O}\right)\left(4-\mathrm{NO}_{2}-\mathrm{pz}\right)_{6}(\mathrm{SCN})_{3}\right]^{3-} \ldots \ldots \ldots \ldots \ldots \ldots \ldots \ldots \ldots . . . . . . . . . . . . .92$

Figure 54. Ball and stick representation of $\left[\mathrm{Fe}_{3}\left(\mu_{3}-\mathrm{O}\right)\left(4-\mathrm{NO}_{2}-\mathrm{pz}\right)_{6}(\mathrm{NCO})_{3}\right]^{2-}(19)$. $\mathrm{TBA}^{+}$ counter ion and hydrogen atoms are omitted for clarity

Figure 55. Ball and stick representation of $\left[\mathrm{Fe}_{3}\left(\mu_{3}-\mathrm{O}\right)\left(4-\mathrm{NO}_{2}-\mathrm{pz}\right)_{6}\left(\mathrm{~N}_{3}\right)_{3}\right]^{2-}(20) \cdot \mathrm{Ph}_{4} \mathrm{P}^{+}$ counter ions and hydrogen atoms are omitted for clarity.

Figure 56. CV of 19 vs. $\mathrm{Fc}^{+} / \mathrm{Fc}$. of $\left[\mathrm{Fe}_{3}\left(\mu_{3}-\mathrm{O}\right)\left(4-\mathrm{NO}_{2}-\mathrm{pz}\right)_{6}(\mathrm{NCO})_{3}\right]^{2-1 / 3-}\left(\mathrm{E}_{1 / 2}=-0.70 \mathrm{~V}\right) .95$

Figure 57. DPV (red) and CV (green) of $20 v s . \mathrm{Fc}^{+} / \mathrm{Fc}$. of $\left[\mathrm{Fe}_{3}\left(\mu_{3}-\mathrm{O}\right)\left(4-\mathrm{NO}_{2^{-}}\right.\right.$ $\left.\mathrm{pz})_{6}\left(\mathrm{~N}_{3}\right)_{3}\right]^{1-2-}\left(\mathrm{E}_{1 / 2}=0.87 \mathrm{~V}\right)$ and of $\left[\mathrm{Fe}_{3}\left(\mu_{3}-\mathrm{O}\right)\left(4-\mathrm{NO}_{2}-\mathrm{pz}\right)_{6}\left(\mathrm{~N}_{3}\right)_{3}\right]^{2^{-1 / 3}-}\left(\mathrm{E}_{1 / 2}=-0.70 \mathrm{~V}\right) \ldots . .96$

Figure 58. UV-Vis- NIR of $\left[\mathrm{Fe}_{3}\left(\mu_{3}-\mathrm{O}\right)\left(4-\mathrm{NO}_{2}-\mathrm{pz}\right)_{6}\left(\mathrm{~N}_{3}\right)_{3}\right]^{-2}$ (red) and product of reduction with $\mathrm{TBABH}_{4}$ (blue) 98

Figure 59. UV-Vis- NIR of (TBA $)_{2}\left[\mathrm{Fe}_{3}\left(\mu_{3}-\mathrm{O}\right)\left(4-\mathrm{NO}_{2}-\mathrm{pz}\right)_{6}\left(\mathrm{~N}_{3}\right)_{3}\right]$ (blue), product from oxidation with ammonium cerium(V) nitrate (green) and bulk electrolysis (orange)..... 99

Figure 60. IR spectra of 20 (blue) and chemical oxidation of 20 (green) ....................... 100

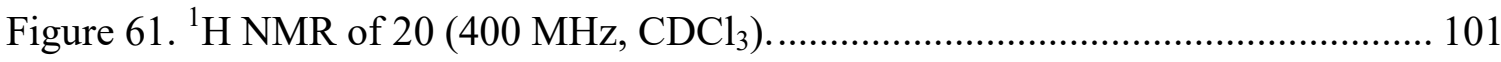

Figure $62 .{ }^{57} \mathrm{Fe}$ Mössbauer spectra of a powdered sample of 20 (A) and reduced product (B) at $80 \mathrm{~K}$. 102 


\section{LIST OF SCHEMES}

SCHEME

PAGE

Scheme 1. Small polaron in iron oxide showing the local structural distortion created by

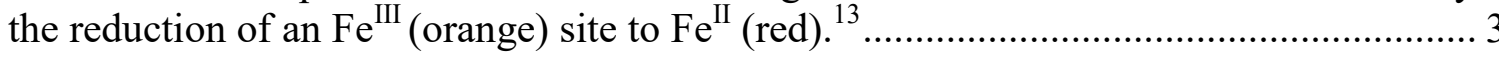

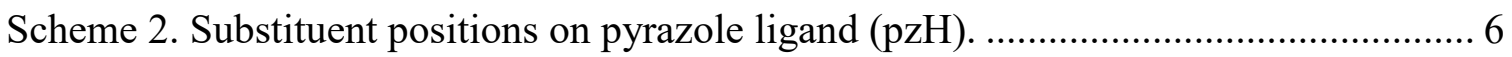

Scheme 3. Coordination modes of pyrazoles $(\mathrm{pzH})$ and pyrazolates $(\mathrm{pz}){ }^{28} \ldots \ldots \ldots \ldots \ldots \ldots \ldots . . . .6$

Scheme 4. Structural comparison between pyrazolate and carboxylate bridging modes. .. 7

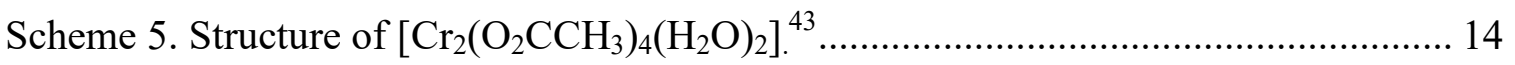

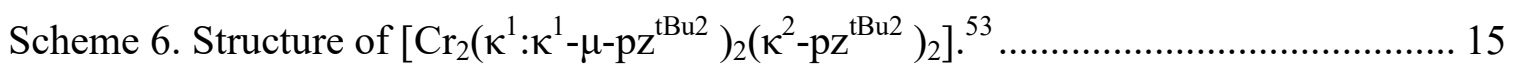

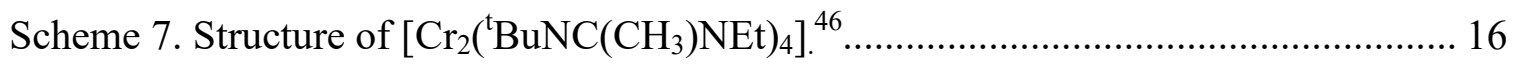

Scheme 8. Mononuclear ferrous and ferric pyrazole adducts as intermediate in the

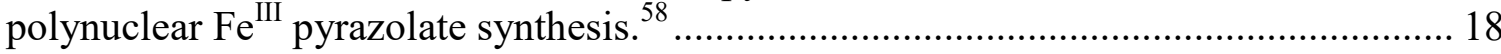

Scheme 9. Splitting of the ground state term ${ }^{5} \mathrm{~F}$ ( $\mathrm{d}^{3}$ free ion) (arrows show spin allowed transitions in an octahedral $\left(\mathrm{O}_{\mathrm{h}}\right)$ environment).

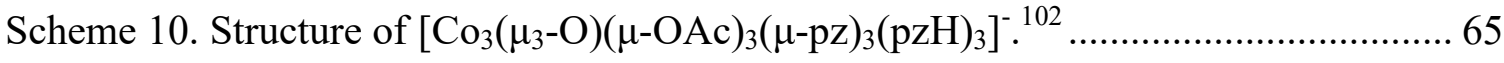

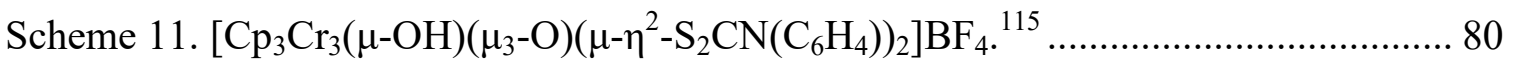

Scheme 12. Summary of chromium(III) pyrazole/pyrazolate chemistry...................... 109 


\section{ABBREVIATIONS AND ACRONYMS}

\begin{tabular}{|c|c|}
\hline $\mathrm{CT}$ & Charge transfer \\
\hline $\mathrm{CV}$ & Cyclic voltammogram \\
\hline DCM & Dichloromethane \\
\hline DMF & Dimethylformamide \\
\hline DPV & Differential pulse voltammogram \\
\hline $\mathrm{Et}_{2} \mathrm{O}$ & Diethyl ether \\
\hline EPR & Electron paramagnetic resonance \\
\hline FT-IR & Fourier transform - infrared \\
\hline HS & high-spin \\
\hline LS & Low-spin \\
\hline ISET & Inner sphere electron transfer \\
\hline IVCT & Intervalance charge transfer \\
\hline $\mathrm{MeCN}$ & Acetonitrile \\
\hline $\mathrm{MeOH}$ & Methanol \\
\hline NMR & Nuclear magnetic resonance \\
\hline OSET & Outer sphere electron transfer \\
\hline py & Pyridine \\
\hline $\mathrm{pz}$ & Pyrazolate \\
\hline pzH & Pyrazole \\
\hline TBA & Tetrabutylammonium \\
\hline $\mathrm{TBABH}_{4}$ & Tetrabutylammonium borohydride \\
\hline THF & Tetrahydrofuran \\
\hline UV-Vis-NIR & Ultraviolet - visible - near infrared \\
\hline XRD & $\mathrm{X}$-ray diffraction \\
\hline ZFS & Zero field splitting \\
\hline
\end{tabular}




\section{LIST OF COMPOUNDS}

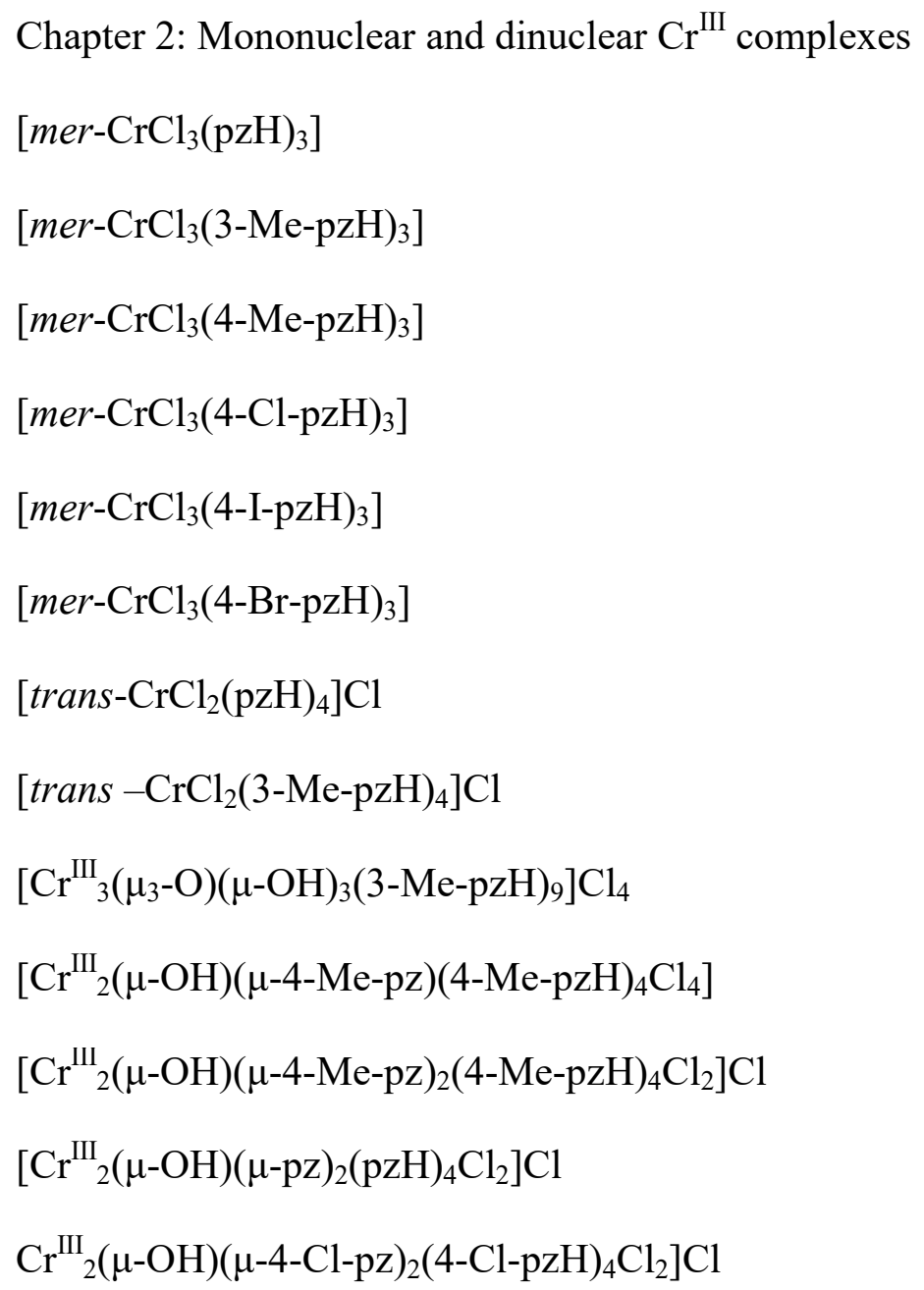

Chapter 3: Trinuclear $\mathrm{Cr}^{\mathrm{III}}$ formate-pyrazolate mixed-ligand complexes

$$
\begin{aligned}
& {\left[\mathrm{Cr}_{3}{ }_{3}{ }_{3}\left(\mu_{3}-\mathrm{O}\right)(\mu-4-\mathrm{Me}-\mathrm{pz})_{3}\left(\mu-\mathrm{O}_{2} \mathrm{CH}\right)_{3}(\mathrm{DMF})_{3}\right]\left(\mathrm{PF}_{6}\right)} \\
& {\left[\mathrm{Cr}_{3}^{\mathrm{III}}{ }_{3}\left(\mu_{3}-\mathrm{O}\right)(\mu-\mathrm{pz})_{3}\left(\mu-\mathrm{O}_{2} \mathrm{CH}\right)_{3}(\mathrm{DMF})_{3}\right]\left(\mathrm{PF}_{6}\right)} \\
& {\left[\mathrm{Cr}_{3}{ }_{3}\left(\mu_{3}-\mathrm{O}\right)(\mu-4-\mathrm{Cl}-\mathrm{pz})_{3}\left(\mu-\mathrm{O}_{2} \mathrm{CH}\right)_{3}(\mathrm{DMF})_{3}\right]\left(\mathrm{NO}_{3}\right)}
\end{aligned}
$$


Chapter 4: Trinuclear $\mathrm{Cr}^{\mathrm{III}}$ pyrazolate complexes

$\left(\mathrm{Ph}_{4} \mathrm{P}\right)_{2}\left[\mathrm{Cr}_{3}\left(\mu_{3}-\mathrm{O}\right)(\mu-4-\mathrm{Cl}-\mathrm{pz})_{6} \mathrm{Cl}_{3}\right]$

$\left(\mathrm{Ph}_{4} \mathrm{P}\right)_{2}\left[\mathrm{Cr}_{3}\left(\mu_{3}-\mathrm{O}\right)(\mu-4-\mathrm{Cl}-\mathrm{pz})_{6} \mathrm{Br}_{3}\right]$

Chapter 5: Trinuclear Fe ${ }^{\text {III }}$ pyrazolate complexes

$(\mathrm{TBA})_{2}\left[\mathrm{Fe}_{3}\left(\mu_{3}-\mathrm{O}\right)\left(4-\mathrm{NO}_{2}-\mathrm{pz}\right)_{6}(\mathrm{NCO})_{3}\right]$

$(\mathrm{TBA})_{2}\left[\mathrm{Fe}_{3}\left(\mu_{3}-\mathrm{O}\right)\left(4-\mathrm{NO}_{2}-\mathrm{pz}\right)_{6}\left(\mathrm{~N}_{3}\right)_{3}\right]$ 


\section{Chapter 1: Introduction}

\section{Metal oxides}

The study of complex mechanisms pertinent to metal oxide structures, have become a wide and interesting subject, because of their diverse applications. Metal oxides have become commercially important because their applications range from their use in surgical implants in a medicinal context (e.g., tungsten and zinc oxides), ${ }^{1}$ antimicrobial agents in an ecological context (e.g., iron and titanium oxides), ${ }^{2,3}$ information storage in electromagnetic devices (e.g., ferromagnetic iron oxides), ${ }^{4}$ and catalysis. ${ }^{5}$

\subsection{Metal oxides in biological systems}

Metal oxides participate in biochemical reactions as electron transfer agents. For example, anaerobic bacteria, such as G. sulfurreducens, use $\mathrm{Fe}^{\mathrm{III}}$ oxides as electron acceptors in their metabolism. ${ }^{6}$ The mechanism of electron transfer (ET) classifies these processes into two categories: inner sphere (IS) and outer sphere (OS) transfer. In the ISET there is a covalent linkage between the reductant and oxidant. Therefore, ISET is rarely observed in biological systems, where the long-range ET between redox active sites is often shielded by bulky proteins. ${ }^{7}$ The OSET occurs between species that remain spatially separated before, during and after the electron transfer. The OSET is at the basis of biological function of iron-sulfur proteins, such as ferrodoxins. ${ }^{8}$ 


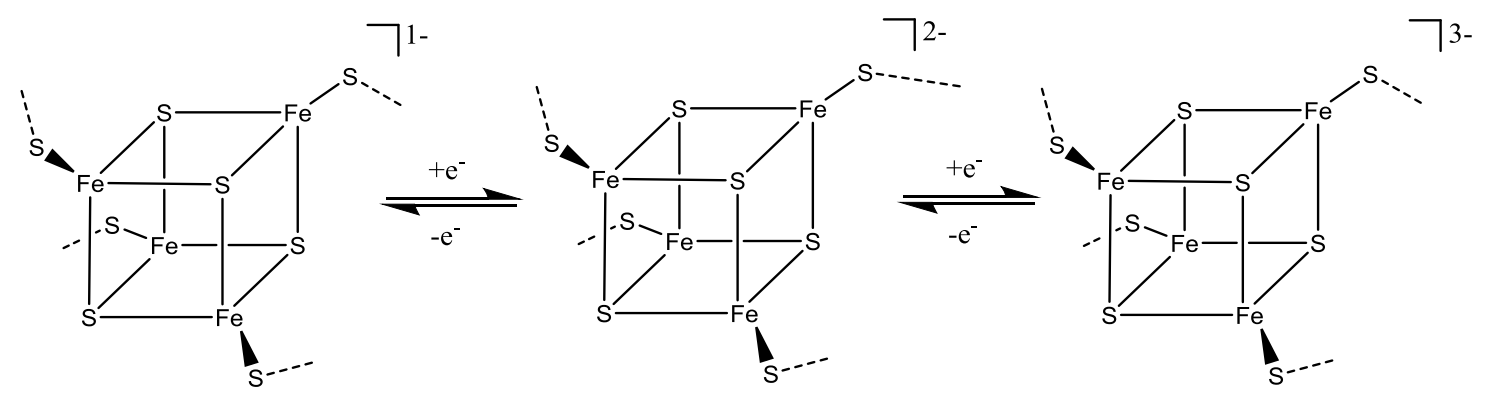

Figure 1. Reduction and oxidation mechanism in the $\mathrm{Fe}_{4} \mathrm{~S}_{4}$-unit of ferredoxins. ${ }^{8}$

\subsection{Classification of mixed-valence cases}

The events of electron donation or acceptance often lead to mixed-valence compounds, in which the oxidation state varies among the metal atoms. The classification of mixed-valent compounds is time-dependent -it depends on how the electron-transfer rate compares to the corresponding timescale of the spectroscopic technique used to monitor the process- in the case of the Robin-Day classification, UV-VIS-NIR spectroscopy. ${ }^{9,10}$ For example, a system that appears to be delocalized by a slow technique may appear as localized by a faster one. Mixed-valent compounds are subdivided into three groups, according to the Robin-Day scheme, as Class I, Class II and Class III, in which the valences are localized, partially delocalized or completely delocalized, respectively (Figure 2). ${ }^{11}$ In Class II and Class III compounds, different magnetic properties are observed, depending on the extent of charge delocalization. The factors that determine whether a mixed-valence complex will belong to Class I, II, or III are not well understood in polynuclear complexes. The charge introduced in an metal oxide lattice (such as an iron oxide lattice) polarizes neighbor atoms and causes 
distortions in the local structure. ${ }^{12}$ The charge and its accompanying distortion are called a polaron (Scheme 1). A polaron can be localized or delocalized over several metal centers, stationary or mobile, the latter being the case of electrically conducting oxides. ${ }^{13}$

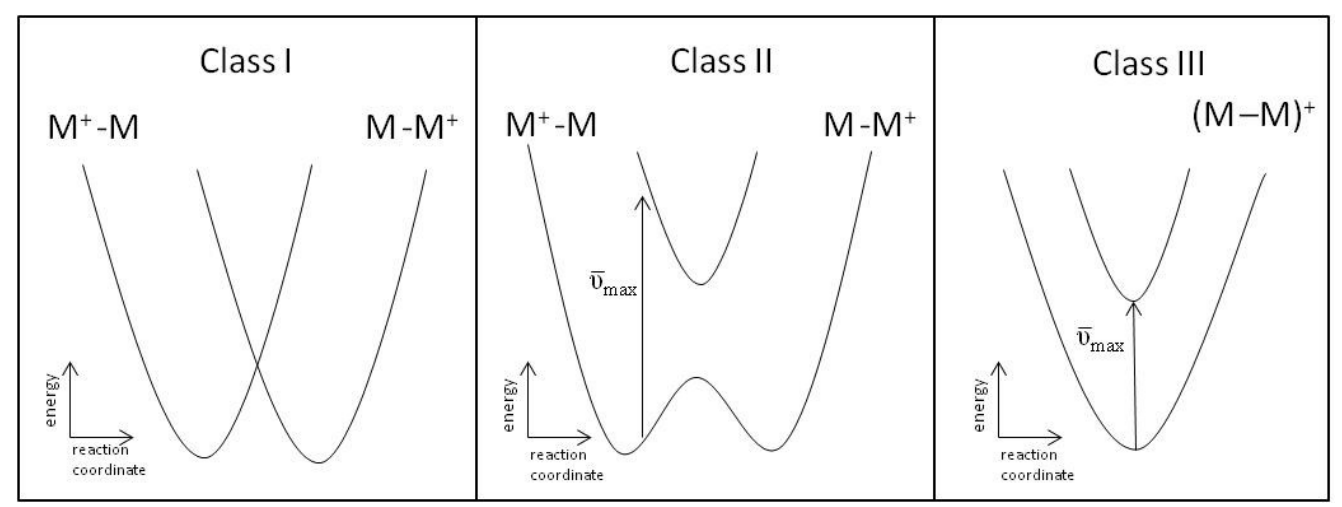

Figure 2. Potential energy diagram for Class I, Class II and Class III species according to the Robin-Day Scheme. Modified from reference ${ }^{11}$.

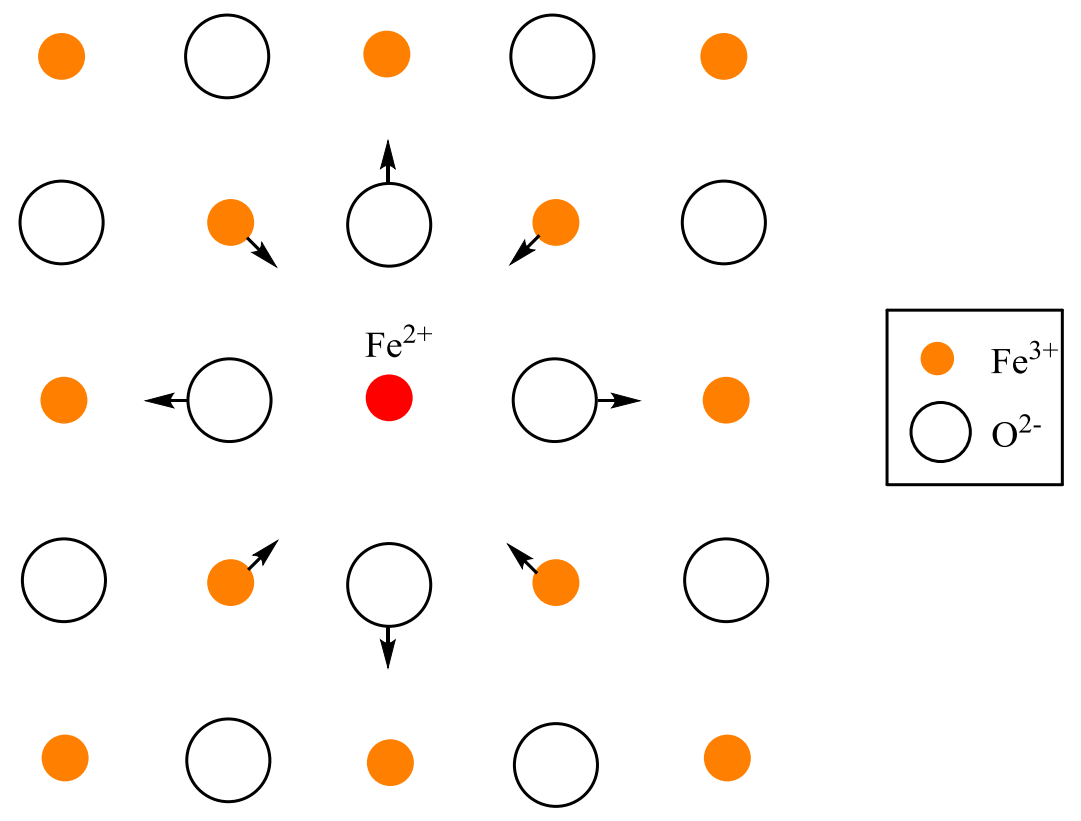

Scheme 1. Small polaron in iron oxide showing the local structural distortion created by the reduction of an $\mathrm{Fe}^{\mathrm{III}}$ (orange) site to $\mathrm{Fe}^{\mathrm{II}}$ (red). ${ }^{13}$ 


\subsection{Metal oxide models}

The understanding of metal oxide properties in nature has been possible from modeling such systems by polynuclear clusters. Synthetic metal clusters have been reliable models for metalloenzyme active sites. ${ }^{14,15}$ Metal cluster model studies provide fundamental insight to the enzyme active site geometries, electronic structures and reaction mechanisms. ${ }^{16,17}$ Synthesis of polynuclear clusters that mimic metalloenzyme active site structures have been reported with multiple bridging ligands, such as Schiff base, oximes, imidazole, carboxylate and pyrazolates. ${ }^{18-21}$

\subsection{Iron complexes as active site models}

Carboxylate-bridged diiron active sites are found in many metalloproteins listed in Table 1. ${ }^{17,22}$ Numerous studies have utilized basic carboxylate, formate and acetate ligands to mimic the amino acid side chains found at the metalloprotein active sites. The first synthetic model of the reduced state of hemerythrin is $\left[\mathrm{Fe}_{2}(\mu-\mathrm{OH})(\mu-\mathrm{OAc})_{2}\left(\mathrm{Me}_{3}-\right.\right.$ TACN $\left.)_{2}\right]^{+}$, depicted in Figure $3 .^{23}$
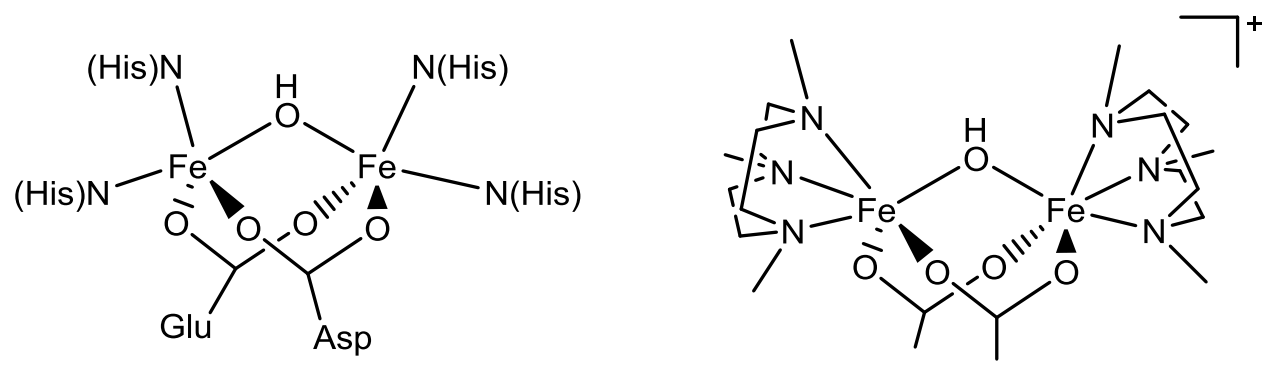

Figure 3. Active site of hemerythrin (left) and its synthetic model (right). ${ }^{17}$ 
Table 1. Identified and characterized diiron metalloproteins. Modified from Tshuva et $a l .^{17}$

\section{Enzyme}

\begin{tabular}{ll}
\hline alkene monooxygenase & alkene epoxidation \\
butane monooxygenase & butane oxidation to alcohol \\
DMQ monooxygenase & quinone generation \\
ferritins & iron storage \\
hemerythrin & dioxygen carrier \\
methane monooxygenase & methane to methanol oxidation \\
phenol hydroxylase & phenol to catechol oxidation \\
purple acid phosphotase & phosphate ester hydrolysis \\
ribonucleotide reductase & tyrosyl radical generator \\
rubrerythrin & putative peroxidase \\
toluene nonooxygenases & toluene to cresol oxidation \\
$\Delta^{9}$ desaturases & alkane conversion to alkene \\
$\omega$-alkane hydroxylase & alkane oxidation to alcohol \\
\hline
\end{tabular}

\subsection{Polynuclear complexes of interest}

Remarkable studies on pyrazole coordination chemistry have been developed since the late 1970 's, ${ }^{18,21,24}$ and pyrazolate complexes have been proven to be good models of metalloprotein active sites. $^{25}$ Furthermore, biological activity and therapeutic properties have been reported for pyrazole containing compounds. ${ }^{26,27}$

Pyrazoles are heterocyclic aromatic rings consisting of three carbon atoms and two vicinal nitrogen atoms (in positions 1 and 2, Scheme 2). After deprotonation of N1, pyrazoles act as monodentate or bidentate ligands. The electronic properties of the pyrazole are mainly influenced by the substituent at the 3-, 4-, and 5-position, whereas, steric properties are influenced only by the 3- and 5-position substituents. The coordination versatility of pyrazoles is depicted in Scheme 3. The coordination ability of the pyrazole ligand depends on the nature of the metal and of the substituents of the carbon atoms on the aromatic ring. ${ }^{28}$ 


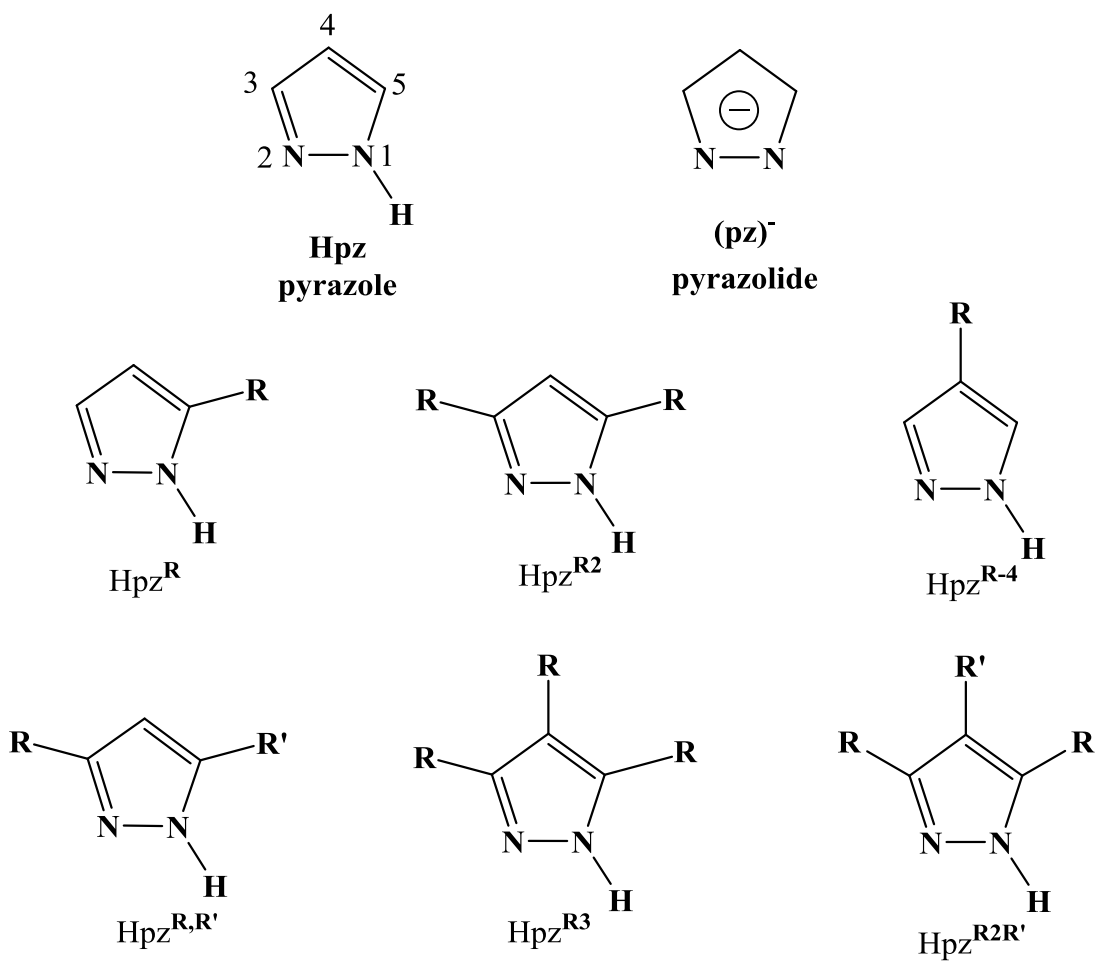

Scheme 2. Substituent positions on pyrazole ligand (pzH).
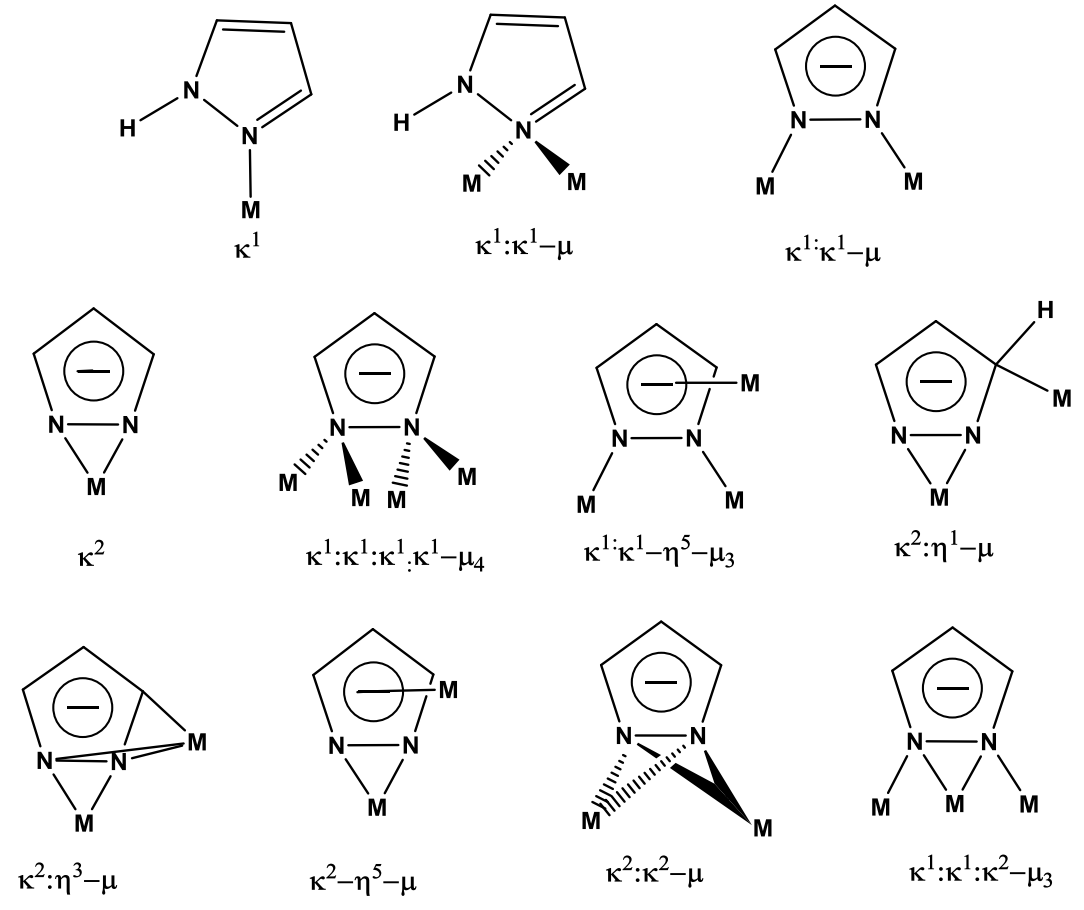

$$
\kappa^{1}: \kappa^{1}: \kappa^{1}: \kappa^{1}-\mu_{4}
$$$$
\kappa^{1:} \kappa^{1}-\eta^{5}-\mu_{3}
$$$$
\kappa^{2}: \eta^{1}-\mu
$$
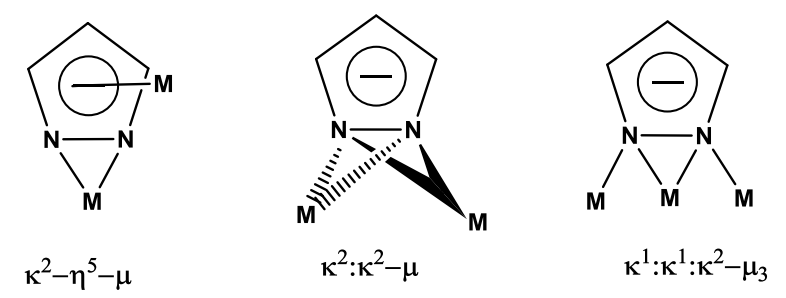

Scheme 3. Coordination modes of pyrazoles (pzH) and pyrazolates (pz). ${ }^{28}$ 


\subsubsection{Trinuclear carboxylate and pyrazolate complexes}

Carboxylate ligands have been broadly compared with the pyrazolate ligands, as there are some structural analogies between complexes of these ligands, even though they differ in their rigidity (Scheme 4) and reactivity. ${ }^{29}$ Different nuclearity pyrazolate and carboxylate complexes have similar $\mathrm{M} \cdots \mathrm{M}$ distances, summarized in Table 2.
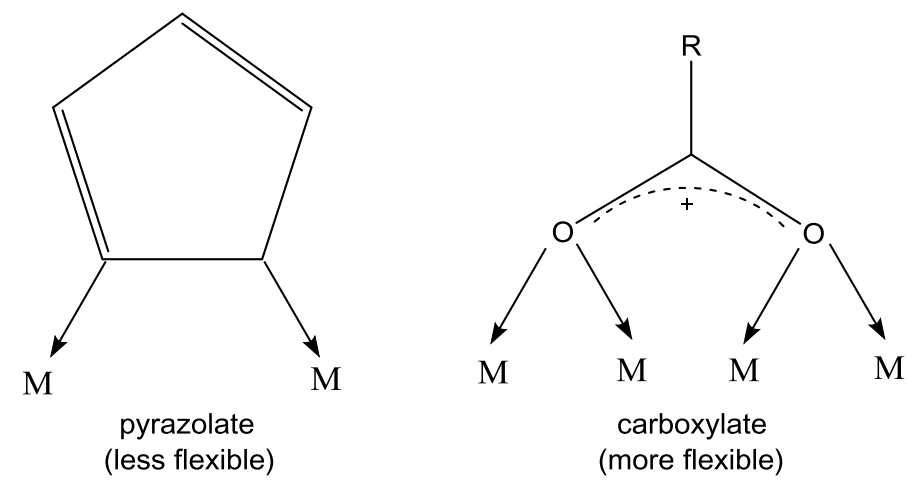

Scheme 4. Structural comparison between pyrazolate and carboxylate bridging modes.

Palladium trimers, with formula $\left[\mathrm{Pd}^{\mathrm{II}}(\mu-\mathrm{OCOR})_{2}\right]_{3}$ and $\left[\mathrm{Pd}^{\mathrm{II}}(\mu-\mathrm{pz})_{2}\right]_{3}(\mathrm{pz} *=\mathrm{pz}$ and 3-Ph-pz) and square planar metal centers, share similar metal-metal distances and luminescent properties. ${ }^{29,30}$ In trinuclear complexes, octahedral metal centers are bridged by an axial $\mu_{3-} \mathrm{O}$ atom, six bidentate ligands occupying the equatorial sites of the metals, the three terminal ligands. Within the isolateral triangle of the $\left[\mathrm{Co}_{3}^{\mathrm{III}}{ }_{3}\left(\mu_{3}-\mathrm{O}\right)\left(\mu-4-\mathrm{NO}_{2}-\right.\right.$ pz) $\left.{ }_{6}\left(\mathrm{NO}_{2}\right)_{3}\right]^{2-}$ complex, the Co $\cdots$ Co distances (Table 2) are significantly shorter than those of the analogous carboxylate $\left[\mathrm{Co}^{\mathrm{III}}{ }_{3}\left(\mu_{3}-\mathrm{O}\right)(\mu-\mathrm{RCOO})_{6} \mathrm{~L}_{3}\right]^{+1},(\mathrm{~L}=$ neutral ligand like $\mathrm{H}_{2} \mathrm{O}, \mathrm{MeOH}$ or py). ${ }^{31}$ In complexes containing iron, the $\left[\mathrm{Fe}^{\mathrm{III}}{ }_{3}\left(\mu_{3}-\mathrm{O}\right)\left(\mu-4-\mathrm{NO}_{2}-\mathrm{pz}\right)_{6} \mathrm{X}_{3}\right]^{2-}$ $(\mathrm{X}=\mathrm{Cl}, \mathrm{Br}$ and $\mathrm{NCS})$ the $\mathrm{Fe}^{\mathrm{III}}{ }_{3}\left(\mu_{3}-\mathrm{O}\right)$-core is structurally indistinguishable from the 
analogous carboxylate $\left[\mathrm{Fe}_{3}^{\mathrm{III}}{ }_{3}\left(\mu_{3}-\mathrm{O}\right)\left(\mu-\mathrm{O}_{2} \mathrm{CR}\right)_{6} \mathrm{~L}_{3}\right]^{+}\left(\mathrm{L}=\right.$ neutral ligand, such as $\mathrm{H}_{2} \mathrm{O}$, $\mathrm{MeOH}$ and py) $)^{32}$; they only differ in their magnetic properties, as a result of structural differences from the bridging ligands. ${ }^{32-35}$
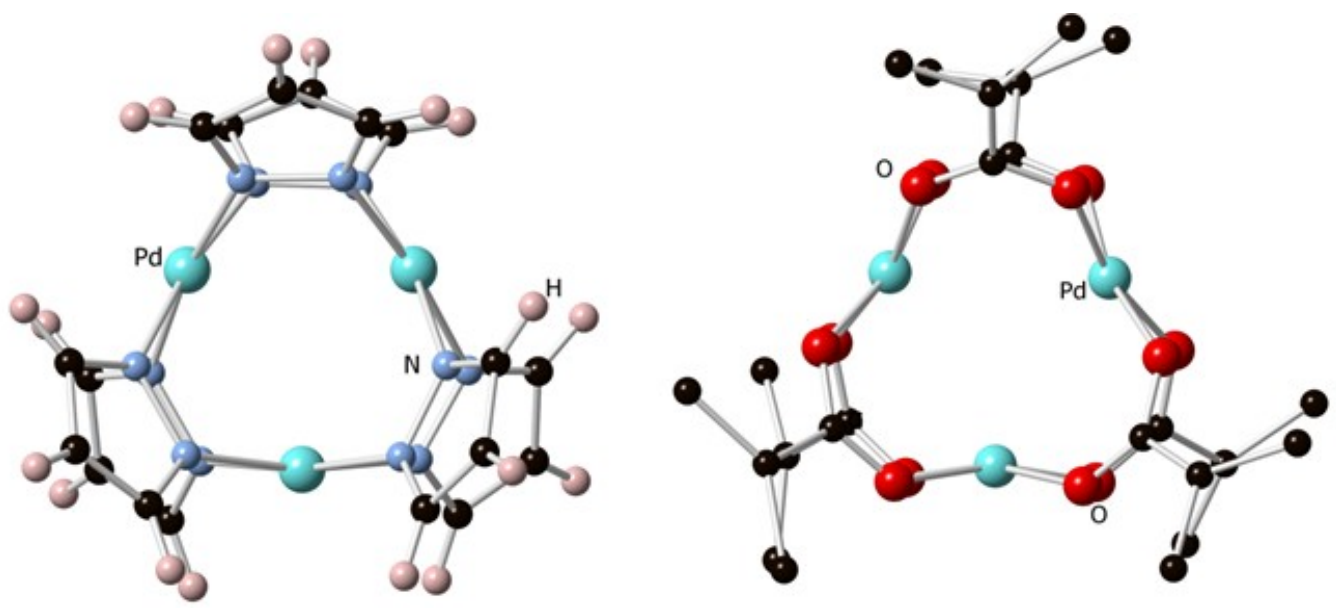

Figure 4. Trinuclear $\mathrm{Pd}^{\mathrm{II}}$ complexes with $\mu-p z$ (left) and $\mu-\mathrm{O}_{2} \mathrm{CR}$ (right) ligands. ${ }^{29,36}$

Table 2. M $\cdots M$ distances $(\AA)$ for pyrazolate and the analogous carboxylate complexes.

\begin{tabular}{lcll}
\multicolumn{1}{c}{ Compound } & \multicolumn{1}{c}{ Distance } & \multicolumn{1}{c}{ Compound } & Distance \\
\hline$\left[\mathrm{Fe}_{3}\left(\mu_{3}-\mathrm{O}\right)\left(\mu-4-\mathrm{NO}_{2}-\mathrm{pz}\right)_{6} \mathrm{Cl}_{3}\right]^{2-}$ & $3.267(1), 3.280(1)^{33}$ & {$\left[\mathrm{Fe}_{3}\left(\mu_{3}-\mathrm{O}\right)\left(\mu-\mathrm{O}_{2} \mathrm{CPh}\right)_{6}(\mathrm{py})_{3}\right]^{+}$} & $3.306(1)^{32}$ \\
{$\left[\mathrm{Pd}_{3}(\mu-\mathrm{pz})_{6}\right]$} & $3.0471(126)^{29}$ & {$\left[\mathrm{Pd}_{3}\left(\mu-\mathrm{O}_{2} \mathrm{R}\right)_{6}\right]$} & $3.131(1)-3.191(1)^{36}$ \\
{$\left[\mathrm{Co}_{3}\left(\mu_{3}-\mathrm{O}\right)\left(\mu-4-\mathrm{NO}_{2}-\mathrm{pz}\right)_{6}\left(\mathrm{NO}_{2}\right)_{3}\right]^{2+}$} & $\begin{array}{c}3.0878(9), 3.0985(9), \\
3.1073(9)^{31}\end{array}$ & {$\left[\mathrm{Co}_{3}\left(\mu_{3}-\mathrm{O}\right)\left(\mu-\mathrm{O}_{2} \mathrm{Ac}\right)_{6} \mathrm{py}_{3}\right]$} & $3.194(1)^{37}$ \\
\hline
\end{tabular}

With regard to their substitution kinetics, carboxylate complexes of platinum, rhodium and ruthenium, range from moderately to highly labile, showing potential as homogeneous catalysts. ${ }^{38}$ On the other hand, the lability of carboxylate complexes is a problem for the study of their redox activity, as they readily decompose. The relative inertness of the pyrazolates gives these complexes a significant advantage for electrochemical studies. 
Redox properties of trinuclear complexes with formula $\left[\mathrm{Fe}_{3}\left(\mu_{3}-\mathrm{O}\right)\left(\mu-4-\mathrm{NO}_{2-}\right.\right.$ $\left.\mathrm{pz}_{6} \mathrm{X}_{3}\right]^{2-}(\mathrm{X}=\mathrm{Cl}, \mathrm{Br}, \mathrm{NCS})$ show one electron reversible reduction and a second irreversible reduction, where the potential is strongly dependent on the electron donating and/or withdrawing properties of the terminal ligand. ${ }^{33-35}$

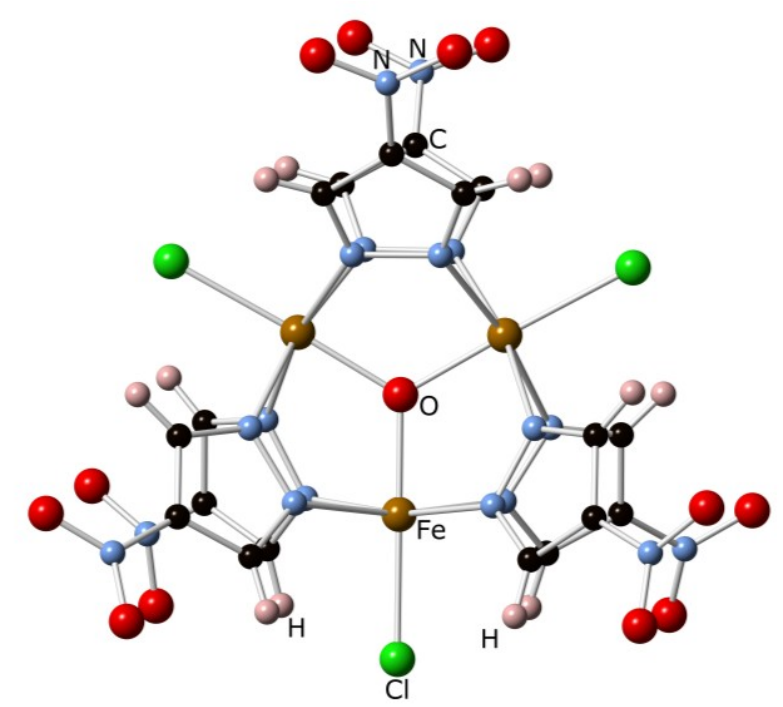

Figure 5. Ball-and-stick representation of $\left[\mathrm{Fe}_{3}\left(\mu_{3}-\mathrm{O}\right)\left(\mu-4-\mathrm{NO}_{2}-\mathrm{pz}_{6} \mathrm{Cl}_{3}\right]^{2-33}\right.$

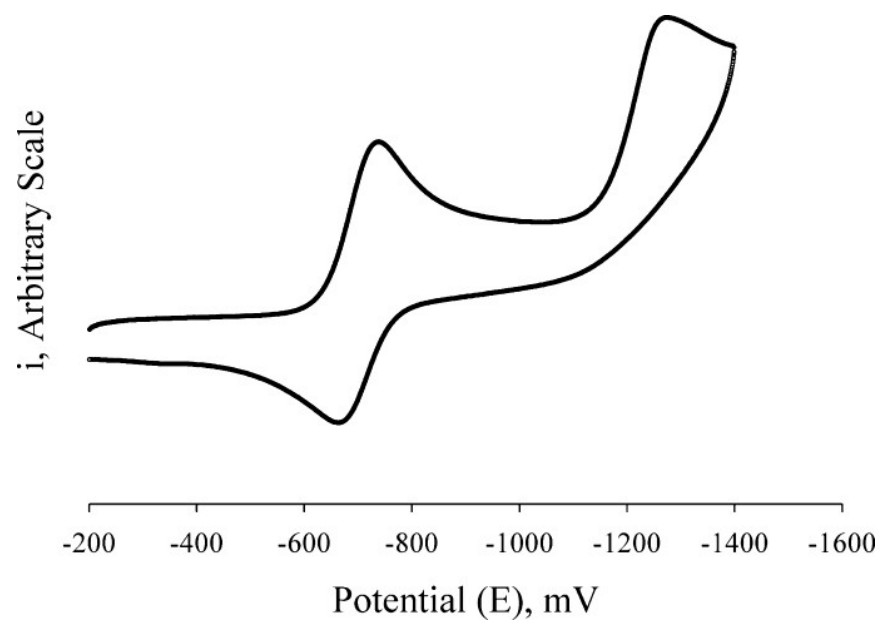

Figure 6. Cyclic voltammogram of $(\mathrm{TBA})_{2}\left[\mathrm{Fe}_{3}\left(\mu_{3}-\mathrm{O}\right)\left(\mu-4-\mathrm{NO}_{2}-\mathrm{pz}\right)_{6} \mathrm{Cl}_{3}\right] v s . \mathrm{Fc}^{+} / \mathrm{Fc}^{33}$ 


\subsubsection{Octanuclear carboxylate and pyrazolate complexes}

The synthesis of an octanuclear chromium(III) carboxylate complex with formula $\left[\mathrm{Cr}_{8}\left(\mu_{4}-\mathrm{O}\right)_{4}\left(\mu-\mathrm{O}_{2} \mathrm{CPh}\right)_{12}\left(\mathrm{O}_{2} \mathrm{CPh}\right)_{4}\right]$ has been achieved via a thermal treatment route. All $\mathrm{Cr}$ centers are in an octahedral environment. ${ }^{39}$ A magnetic susceptibility study concluded that an antiferromagnetic exchange operates among the $\mathrm{Cr}$ centers, with exchange parameters $\mathrm{J}_{1}=-2.1 .0 \mathrm{~cm}^{-1}$ and $\mathrm{J}_{2}=-3.4 \mathrm{~cm}^{-1}$ representing the exchange between the $\mathrm{Cr}$ atoms within the central heterocubane and the exchange between central and outer $\mathrm{Cr}$ centers, respectively. ${ }^{39}$ However, redox modification of this $\mathrm{Cr}_{8}$ complex to achieve mixed-valence $\mathrm{Cr}^{\mathrm{III} / \mathrm{IV}}$ or $\mathrm{Cr}^{\mathrm{II} / \mathrm{III}}$ species has not been reported to date, possibly because of the well-known lability of carboxylate complexes, which may only cause irreversible redox processes.

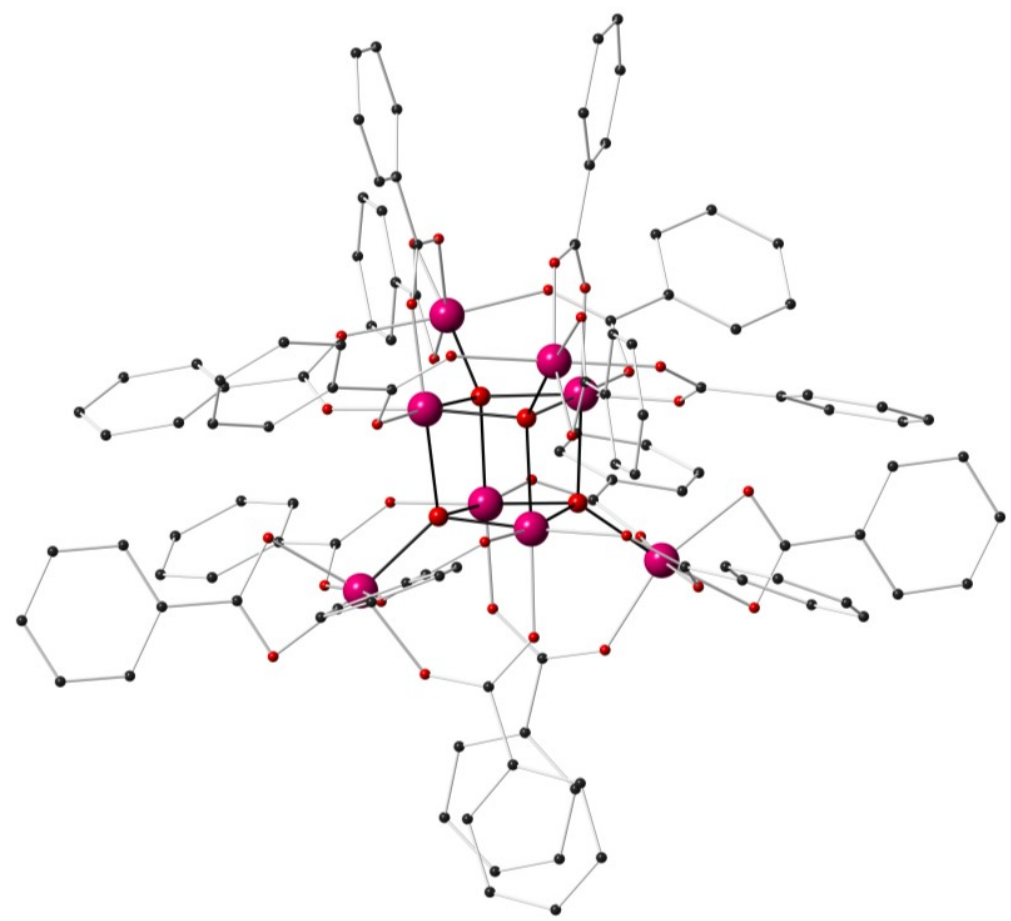

Figure 7. Structure of $\left[\mathrm{Cr}_{8}\left(\mu_{4}-\mathrm{O}\right)_{4}\left(\mu-\mathrm{O}_{2} \mathrm{CPh}\right)_{12}\left(\mathrm{O}_{2} \mathrm{CPh}\right)_{4}\right]$. H-atoms are omitted for clarity. $(\mathrm{Cr} \text {, pink; O, red; } \mathrm{C} \text {, black })^{39}$ 
An analogous structure to the $\mathrm{Cr}_{8}$ carboxylate complex has been synthesized, with the general formula $\left[\mathrm{Fe}_{8}\left(\mu_{4}-\mathrm{O}\right)_{4}(4-\mathrm{R}-\mathrm{pz})_{12} \mathrm{X}_{4}\right]\left(\mathrm{pz}=\right.$ pyrazolate anion, $\left.\mathrm{C}_{3} \mathrm{H}_{3} \mathrm{~N}_{2}\right) .{ }^{40}$ These complexes have an $\mathrm{Fe}_{8} \mathrm{O}_{4}$ motif in the core surrounded by twelve bridging pyrazolate and four terminal ligands. They are structurally analogous to the $\mathrm{Fe}_{8} \mathrm{O}_{4}$ motif that constitutes minerals, such as magnetite $\left(\mathrm{Fe}_{3} \mathrm{O}_{4}\right)$, maghemite $\left(\mathrm{\gamma}-\mathrm{Fe}_{2} \mathrm{O}_{3}\right)$, and ferrihydrite, when repeated in three dimensions. The magnetic and electrical properties of these minerals have led to several applications. ${ }^{41}$ The variation of the 4-position substituent $(\mathrm{R})$ in the pyrazole with $\mathrm{R}=\mathrm{Me}$, Et, $\mathrm{Ph}, \mathrm{CH}_{2} \mathrm{CH}_{2} \mathrm{Cl}, \mathrm{CH}_{2} \mathrm{CH}_{2} \mathrm{OH}, \mathrm{Cl}, \mathrm{Br}$ and $\mathrm{I}$, and the terminal ligand $\mathrm{X}=\mathrm{NCS}, \mathrm{OAr}, \mathrm{N}_{3}, \mathrm{NCO}, \mathrm{Cl}$, and $\mathrm{Br}$, give rise to similar behavior with regard to their redox and magnetic properties.

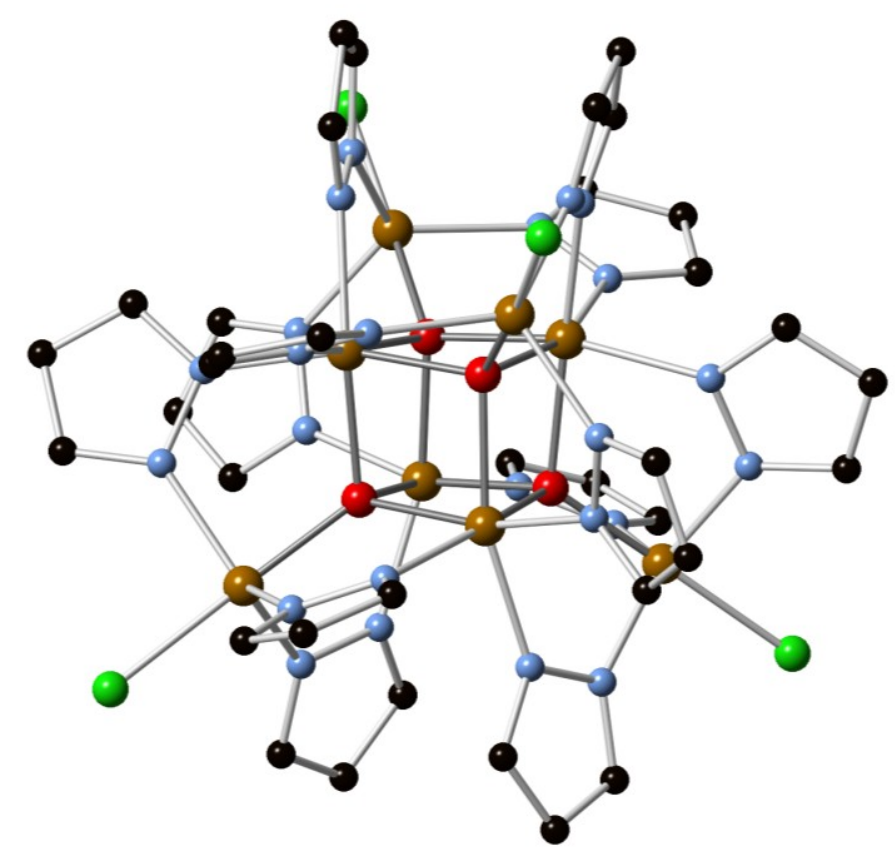

Figure 8. Ball-and-stick representation of $\left[\mathrm{Fe}^{\mathrm{IIII}}{ }_{8}\left(\mu_{4}-\mathrm{O}\right)_{4}(\mu-\mathrm{pz})_{12} \mathrm{Cl}_{4}\right](\mathrm{Fe}$, brown; $\mathrm{Cl}$, green; $\mathrm{O}$, red; $\mathrm{N}$, blue; $\mathrm{C}$, black). ${ }^{40}$ 


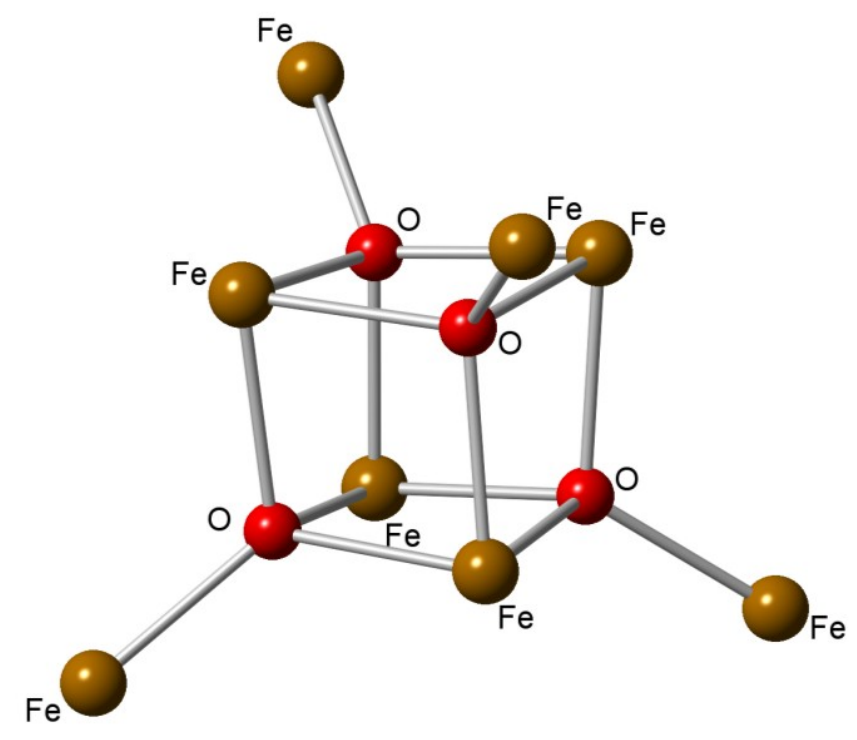

Figure 9. Structure of $\mathrm{Fe}_{8} \mathrm{O}_{4}$ core of the $\left[\mathrm{Fe}^{\mathrm{III}}{ }_{8}\left(\mu_{4}-\mathrm{O}\right)_{4}\left(\mu-\mathrm{pz}^{*}\right)_{12} \mathrm{X}_{4}\right]$.

The electrochemical study of $\left[\mathrm{Fe}_{8}\left(\mu_{4}-\mathrm{O}\right)_{4}(\mu-\mathrm{pz})_{12} \mathrm{Cl}_{4}\right]$ showed four reversible reduction processes at $-0.43 \mathrm{~V},-0.78 \mathrm{~V},-1.07 \mathrm{~V}$ and $-1.38 \mathrm{~V}\left(\mathrm{vs} . \mathrm{Fc}^{+} / \mathrm{Fc}\right)$. These redox potentials change with the variation of the terminal ligands and the substitution of the pyrazolate ligands. The narrower potential window of the above processes compared to the corresponding analogous sulfur structures, for example, $\mathrm{Fe}_{4} \mathrm{~S}_{4}$ cubanes found in ferrodoxins, suggests that these oxo-centered iron cores are more efficient electron transfer agents. The superior electron transfer properties of the $\mathrm{Fe}_{4} \mathrm{O}_{4}$ core provides evidence of the existence of four reduced states beyond the neutral all-ferric complex and also suggests the possible existence of these cores in nature. ${ }^{40}$ 


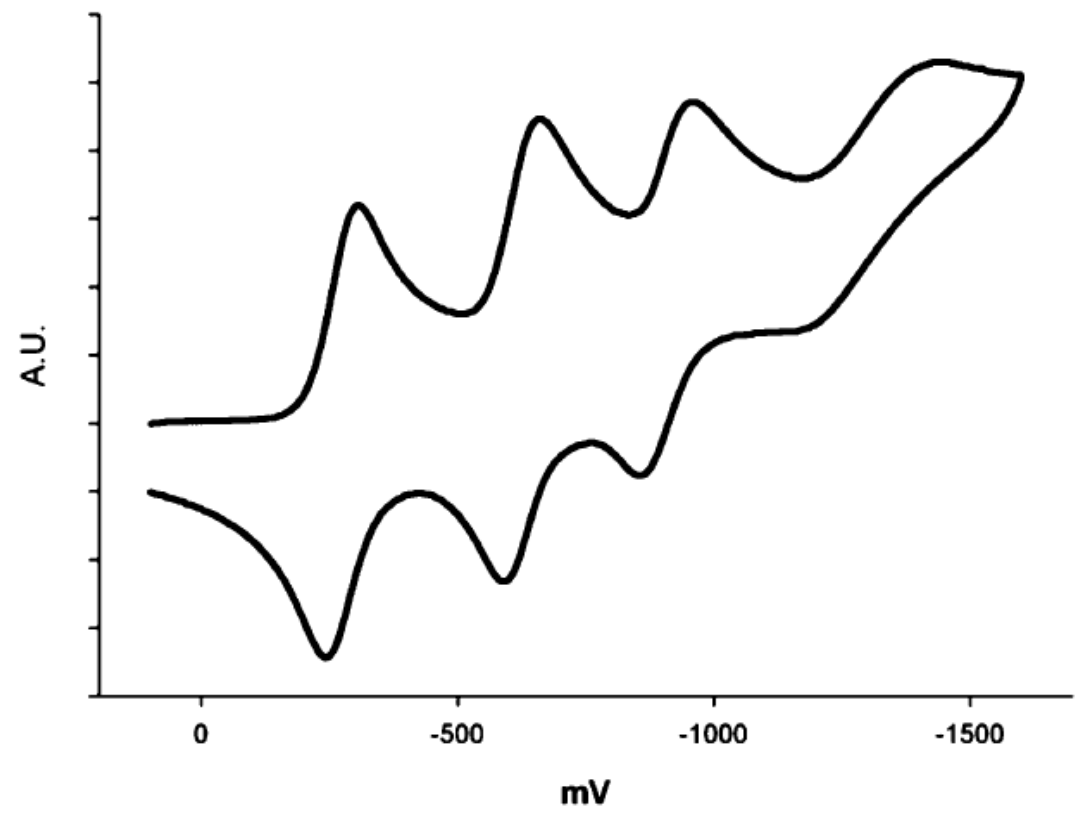

Figure 10. Cyclic voltamogram of $\left[\mathrm{Fe}^{\mathrm{III}}{ }_{8}\left(\mu_{4}-\mathrm{O}\right)_{4}(\mu-\mathrm{pz})_{12} \mathrm{Br}_{4}\right]$ in $0.5 \mathrm{M}$ TBAPF ${ }_{6} / \mathrm{DCM}$, Ptdisk working electrode, $v s . \mathrm{Fc}^{+} / \mathrm{Fc}$. Reproduced from Baran et al. ${ }^{40}$

Also, previous computational analysis of the magnetic susceptibility of these $\mathrm{Fe}_{4} \mathrm{O}_{4}$-core complexes has revealed antiferromagnetic coupling between the iron centers within the cubane core, which are mediated by the oxo-bridges, and a stronger coupling between the inner (octahedral) and outer iron (trigonal bipyramidal) centers, with coupling parameters $\mathrm{J}_{1} / \mathrm{hc}=-2.1 \mathrm{~cm}^{-1}$ and $\mathrm{J}_{2} / \mathrm{hc}=-50.6 \mathrm{~cm}^{-1}$, respectively, similar to the proposed scheme for $\left[\mathrm{Cr}_{8}\right]$. $^{40}$ 


\subsubsection{Dinuclear carboxylate and pyrazolate complexes}

Dinuclear chromium carboxylates were first introduced as " $\mathrm{CrC}_{4} \mathrm{H}_{4} \mathrm{O}_{5}$ " by Peligot more than a century ago. ${ }^{42}$ The complex is identified now as $\left[\mathrm{Cr}_{2}\left(\mathrm{O}_{2} \mathrm{CCH}_{3}\right)_{4}\left(\mathrm{H}_{2} \mathrm{O}\right)_{2}\right]$ with 2.362(1) $\AA \mathrm{Cr} \cdots \mathrm{Cr}$ distance, indicative of a metal-metal interaction. ${ }^{43}$ Chromium complexes with metal-metal bonds are subject of experimental and theoretical investigation, because their multiple bonds can give insight in the metal-metal bonding theory. ${ }^{44}$ Reported $\mathrm{Cr} \cdots \mathrm{Cr}$ distances range from 1.74 to $2.69 \AA$, for quintaply to singly bonded species, respectively. ${ }^{45-48}$

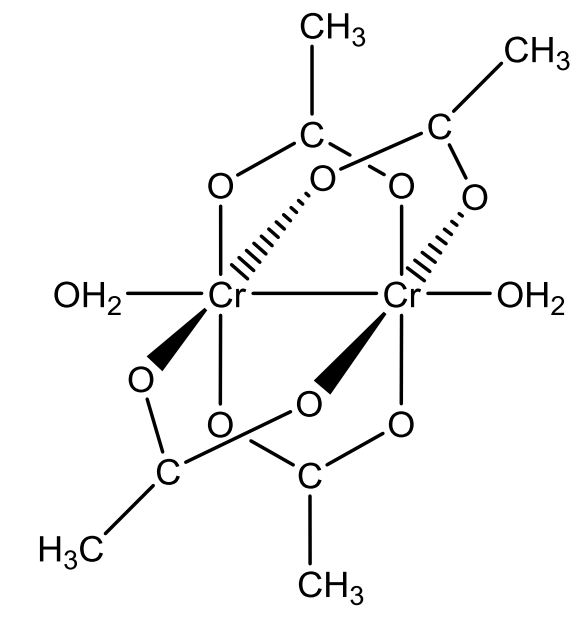

Scheme 5. Structure of $\left[\mathrm{Cr}_{2}\left(\mathrm{O}_{2} \mathrm{CCH}_{3}\right)_{4}\left(\mathrm{H}_{2} \mathrm{O}\right)_{2}\right]^{43}$

Over the years many carboxylate complexes have been reported with metal-tometal distances ranging from $\sim 2.3$ to $\sim 2.6 \AA .^{44}$ Theoretical studies have determined that both the bridging and axial ligands affect the $\mathrm{Cr}-\mathrm{Cr}$ bond length. ${ }^{49}$ The effects of axial and bridging ligands have been experimentally explored. Elongation of the $\mathrm{Cr}-\mathrm{Cr}$ distance of $\left[\mathrm{Cr}_{2}\left(\mathrm{O}_{2} \mathrm{CR}\right)_{4} \mathrm{~L}_{2}\right]$ complexes can be achieved substituting with donor ligands (L) in the axial coordination sites. ${ }^{44,50,51}$ Changing the bridging ligand in dinuclear 
complexes with no axial ligands demonstrated that the change of $\mathrm{N}, \mathrm{N}$ and $\mathrm{N}, \mathrm{O}$ type ligands with carboxylates have little effect on the $\mathrm{Cr}$-Cr bond length, contrary to theoretical expectations. ${ }^{52}$

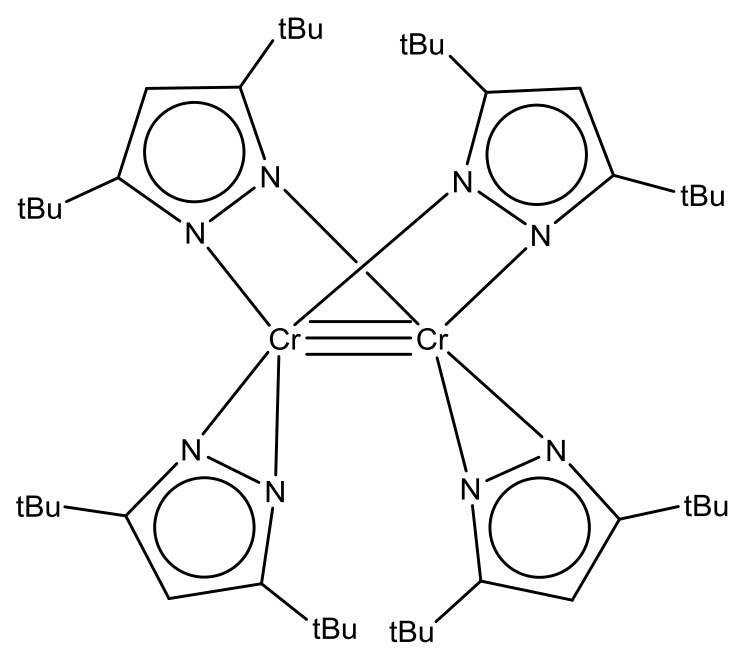

Scheme 6. Structure of $\left[\mathrm{Cr}_{2}\left(\kappa^{1}: \kappa^{1}-\mu-\mathrm{pz}^{\mathrm{tBu} 2}\right)_{2}\left(\kappa^{2}-\mathrm{pz}^{\mathrm{tBu} 2}\right)_{2}\right]^{53}$

More recently, structural analysis of a dinuclear complex of formula $\left[\mathrm{Cr}_{2}^{\mathrm{II}}{ }_{2}\left(\kappa^{1}: \kappa^{1}-\right.\right.$ $\left.\left.\mu-\mathrm{pz}^{\mathrm{tBu} 2}\right)_{2}\left(\kappa^{2}-\mathrm{pz}^{\mathrm{tBu} 2}\right)_{2}\right]$ (Scheme 6), with $\mathrm{Cr} \cdots \mathrm{Cr}$ distance $2.7156(7) \AA$, has given insight of metal-to-metal bonding at the high limit of the known $\mathrm{Cr} \cdots \mathrm{Cr}$ distance range and is recognized as a weak $\mathrm{Cr}-\mathrm{Cr}$ bond. ${ }^{53}$ Dimeric pyrazolate complex does not adopt a paddlewheel structure commonly observed for $\mathrm{Cr}_{4} \mathrm{~L}_{4}$ acetate complexes. A similar reported structure $\left.\left[\mathrm{Cr}_{2}{ }_{2}{ }^{\mathrm{t}} \mathrm{BuNC}\left(\mathrm{CH}_{3}\right) \mathrm{NEt}\right)_{4}\right]$ (Scheme 7) shows a significantly shorter $\mathrm{Cr}$ Cr bond of 1.960(1) $\AA$ compared to the dimeric pyrazolate complex. Here the limiting factor is the strain imposed on the $\mathrm{Cr}-\mathrm{N}-\mathrm{N}$ angles by the short $\mathrm{Cr}-\mathrm{Cr}$ bonds in the pyrazolate complex. While the amidinate bridges allow the Cr- atoms to approach its other, the $\mathrm{sp}^{2}$ donor orbital of the pyrazole ligands, favoring a Cr-N-N angle of $\sim 120^{\circ}$, are 
distorted by short $\mathrm{Cr}-\mathrm{Cr}$ bonds. ${ }^{46}$ Inconsistent $\mathrm{Cr} \cdots \mathrm{Cr}$ distances between dinuclear carboxylate, amidinate and pyrazolate complexes contradicts the structural analogy, between carboxylates and pyrazolates, that had been determined previously. ${ }^{30,31,33}$

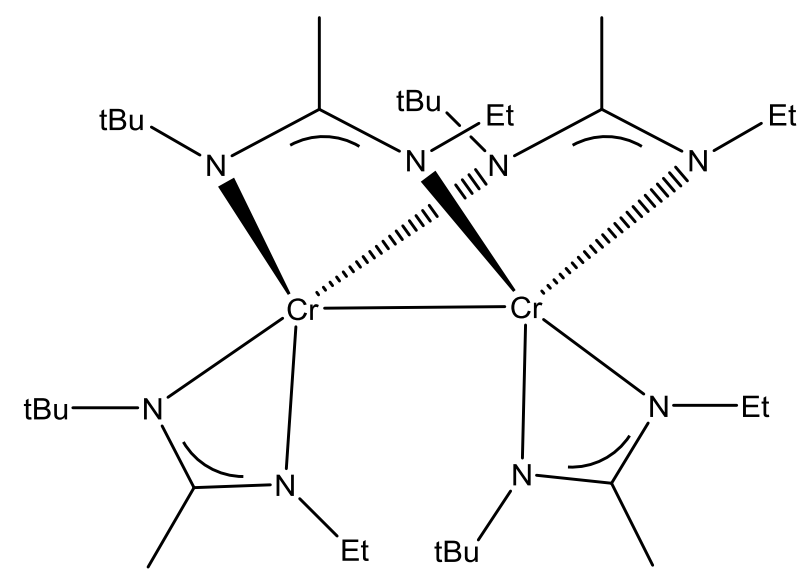

Scheme 7. Structure of $\left[\mathrm{Cr}_{2}\left({ }^{\mathrm{t}} \mathrm{BuNC}\left(\mathrm{CH}_{3}\right) \mathrm{NEt}\right)_{4}\right]{ }^{46}$

\subsection{Hypothesis and rationale}

There are clear structural analogies between carboxylate and pyrazolate complexes of iron, palladium, platinum, copper, and cobalt. In the case of chromium, such structural parallel has not been observed between analogous dinuclear carboxylate and pyrazolate complexes. However, it holds true for higher nuclearity complexes with more than two metal centers. The existence of analogous dimeric structures of chromium carboxylate and pyrazolate, compel the current research to synthesize polynuclear chromium(III) pyrazolate complexes, which will make their redox modification accessible because of the inertness of pyrazolate ligands compared to carboxylates.

The complexity of magnetism and spectroscopy of trinuclear and octanuclear iron pyrazolate complexes, observed in experimental magnetic susceptibility data, EPR, and 
NMR spectra, arises from their $(2 \mathrm{~S}+1)^{\mathrm{N}}$ microstates, where $\mathrm{S}$ is the spin of each metal center and $\mathrm{N}$ is the number of metal centers. High-spin $\mathrm{Fe}^{\mathrm{III}}{ }_{3}$ complexes $(\mathrm{S}=5 / 2)$ have $6^{3}$ $=216$ microstates and high-spin $\mathrm{Fe}^{\mathrm{IIII}}{ }_{8}, 6^{8} \approx 1.7 \times 10^{6}$ microstates. Complexes containing chromium(III) $(\mathrm{S}=3 / 2)$ of these structural types $\left(\mathrm{M}_{3}\right.$ and $\left.\mathrm{M}_{8}\right)$ would simplify the problem of magnetic exchange in these motifs, yielding species with $4^{3}=64$ and $4^{8}=$ 65,536 microstates, respectively.

Upon chemical reduction of trinuclear and octanuclear pyrazolate complexes, mixed-valent species are accessed. Mixed-valent complexes are characterized as localized or delocalized systems. ${ }^{54}$ When electron delocalization among the heterovalent metal centers is permitted, the magnetic exchange becomes further complicated by the double exchange phenomenon. ${ }^{55-57}$ Similar questions arise for other $\mathrm{M}_{3}$ or $\mathrm{M}_{8}$ complexes with the same structural motif.

The current research focuses on the synthesis of polynuclear electrochemically active chromium pyrazolate complexes. The study of chromium pyrazole/pyrazolate chemistry has not been developed, elsewhere. The following strategies have been applied towards that overall goal:

1) Synthesis, characterization, and study of mononuclear chromium pyrazole adducts to be further used as starting materials for the preparation of polynuclear species.

Pyrazole, as a versatile ligand, can be deprotonated to form bridging bidentate anions. Synthetic strategies starting from mononuclear pyrazole adducts are a viable approach in the preparation of polynuclear homo- and hetero-metallic complexes. Mononuclear iron(III) pyrazole complexes have been isolated and characterized as 
intermediate species in the one-pot synthesis of tri- and octa-nuclear iron pyrazolate complexes (Scheme 8$){ }^{58}$ The synthesis of mononuclear chromium(III) complexes is a practical approach for the main goal of obtaining polynuclear $\mathrm{Cr}^{\mathrm{III}}$ pyrazolate complexes.

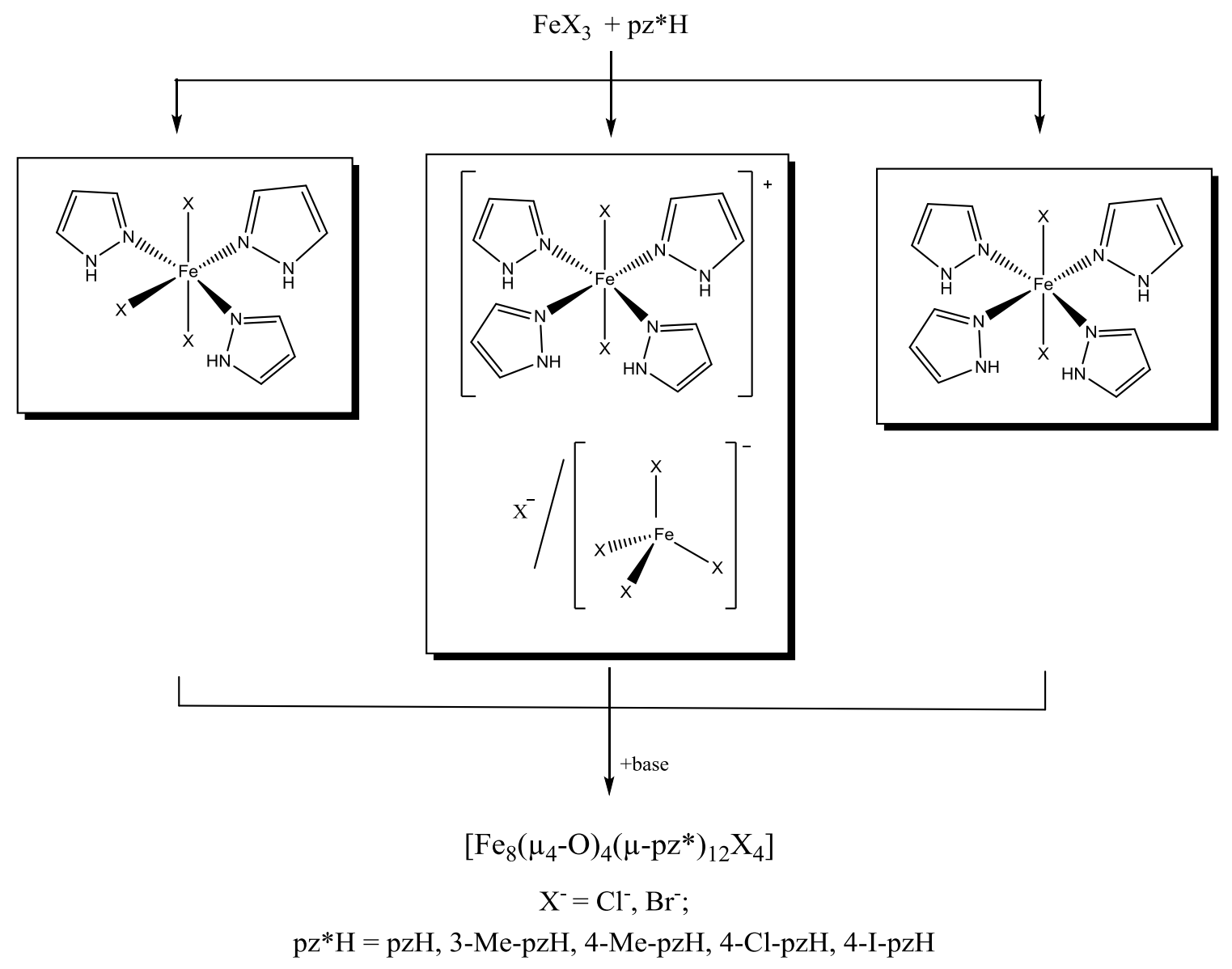

Scheme 8. Mononuclear ferrous and ferric pyrazole adducts as intermediate in the polynuclear $\mathrm{Fe}^{\mathrm{III}}$ pyrazolate synthesis. ${ }^{58}$ 
2) Synthesis of chromium pyrazolate complexes using thermally assisted methods, analogous to the experimental method used to synthesize chromium carboxylate complexes.

Most transition metal coordination reactions, to afford large polymetalic clusters of transition metals, are performed at standard conditions (temperature and pressure). When using inert ions, such as $\mathrm{Cr}^{3+}$, alternative methods have been pursued. ${ }^{59}$ Solvothermal syntheses have become widely used for metal complexes of $\mathrm{Cr}, \mathrm{Fe}, \mathrm{Mn}$ and Ni. ${ }^{60-63}$ Temperature, pressure, and more recently microwave heating are experimental synthesis conditions explored by many inorganic chemists. Microwave assisted synthesis has improved the reaction time and yield of many synthetic procedures. Additionally, it has lead to novel product formation from the alternative kinetic pathways accessed by the addition of microwave energy. The use of thermally and microwave assisted syntheses will be explored in this research. 


\section{Chapter 2: Chromium pyrazole/pyrazolate complexes}

\section{Synthesis of mononuclear chromium pyrazole complexes}

\subsection{Introduction}

There is vast literature on synthetic approaches to obtain polynuclear complexes, one of which is the oligomerization of simple mononuclear starting materials. Several transition metals have been reported to form polynuclear pyrazolate complexes; however, the chromium members of the group have not been fully explored. ${ }^{21}$

The use of mononuclear chromium(III) complexes with pyrazole can serve as an efficient strategy to obtain higher nuclearity complexes upon deprotonation by a base, as has been demonstrated with mononuclear iron pyrazole complexes. ${ }^{58}$ Despite considerable study on mononuclear imidazole and pyrazole chromium(II) complexes, chromium(III) ion has been overlooked. ${ }^{64}$ Currently, few chromium (III) complexes with imidazole derivatives have been reported and characterized by infrared, Raman, and EPR

spectroscopy. ${ }^{65}$ Here we present the first series of chromium(III) pyrazole complexes and additional products from their synthesis.

\subsection{Results and discussion}

\subsubsection{Synthesis of $\mathrm{Cr}^{\mathrm{III}}$ monomers}

The complex $\left[\right.$ mer- $\left.\mathrm{Cr}^{\mathrm{III}} \mathrm{Cl}_{3}(\mathrm{pzH})_{3}\right]$ (1) was obtained by reacting $\mathrm{CrCl}_{3} \cdot 6 \mathrm{H}_{2} \mathrm{O}$ and pzH in THF, while $\left[\right.$ trans- $\left.-\mathrm{Cr}^{\mathrm{III}} \mathrm{Cl}_{2}(\mathrm{pzH})_{4}\right] \mathrm{Cl}$ (7) was obtained from the reaction of anhydrous $\mathrm{CrCl}_{2}$ with pzH in methanol. Scapacci has reported the analogous $\mathrm{Cr}^{\mathrm{II}}$ complex as $\left[\right.$ trans $\left.-\mathrm{Cr}^{\mathrm{II}}(\mathrm{pzH})_{4} \mathrm{X}_{2}\right](\mathrm{X}=\mathrm{Cl}, \mathrm{Br}$ and $\mathrm{I}) .{ }^{64}$ 
The reaction of $\mathrm{CrCl}_{2}$ and 3-Me-pzH in methanol results in mononuclear complexes of two structural types: $\left[\right.$ mer- $\left.\mathrm{Cr}^{\mathrm{III}} \mathrm{Cl}_{3}(3-\mathrm{Me}-\mathrm{pzH})_{3}\right]$ (2) and $\left[\right.$ trans $-\mathrm{Cr}^{\mathrm{III}} \mathrm{Cl}_{2}(3-$ $\left.\mathrm{Me}-\mathrm{pzH})_{4}\right] \mathrm{Cl}(\mathbf{8})$.

Using similar conditions as for $\mathrm{pzH}$, complex $\left[\mathrm{mer}-\mathrm{Cr}^{\mathrm{III}} \mathrm{Cl}_{3}(4-\mathrm{Me}-\mathrm{pzH})_{3}\right]$ (4) was obtained from the reaction of $\mathrm{CrCl}_{3} \cdot 6 \mathrm{H}_{2} \mathrm{O}$ and 4-Me-pzH in THF, while the complex trans- $\left[\mathrm{Cr}^{\mathrm{III}} \mathrm{Cl}_{2}(4-\mathrm{Me}-\mathrm{pzH})_{4}\right] \mathrm{Cl}$ was not isolated. A purple/pink solution, characteristic of the trans-complex, was obtained from the reaction workup, which will be discussed further in section 2.2.6. This same observation was obtained for synthesis of mer- $\mathrm{Cr}^{\mathrm{III}}$ complexes with 4-Cl-pzH, 4-Br-pzH and 4-I-pzH.

\subsubsection{Crystallographic description of $\mathrm{Cr}^{\mathrm{III}}$ monomers}

Crystallographic data collection and refinement parameters for 1-6 and 7-8 are summarized in Table 14 and Table 15, respectively. Complexes $\mathbf{1}$ and $\mathbf{8}$ crystallized in monoclinic $C 2 / c$ space group with half molecule per asymmetric unit. Complex $\mathbf{1}$ crystallized with the $\mathrm{Cl}-\mathrm{Cr}-\mathrm{N}(\mathrm{pzH})$ atoms on a 2-fold rotation axis. Complexes $\mathbf{2}$ and $\mathbf{3}$ crystallized in orthorhombic space group, $P n a 2_{1}$ and $P 2_{1} 2_{1} 2_{1}$, respectively. Both, complexes 4 and $\mathbf{6}$ crystallized in triclinic $P-1$ space group. Complexes $\mathbf{5}$ and $\mathbf{8}$ crystallized in monoclinic $C 2 / c$ and $P 2_{l} / c$ space group respectively. Lastly, complex 7 crystallized in triclinic $P-l$ space group with two half-molecules related by an inversion center on the metal atom. 
All complexes contain a 6-coordinate pseudooctahedral $\mathrm{Cr}^{\mathrm{III}}$ center with [mer$\left.\mathrm{CrCl}_{3}\left(\mathrm{pz}^{*} \mathrm{H}\right)_{3}\right]$ or $\left[\right.$ trans $\left.-\mathrm{CrCl}_{2}(\mathrm{pz} * \mathrm{H})_{4}\right] \mathrm{Cl}$ coordination sphere. The oxidation state of the metal center was determined from charge balancing the chemical composition from the crystal structure and using data from elemental analysis. Complexes $\mathbf{7}$ and $\mathbf{8}$ have the pyrazoles trans to each other in an anti configuration.

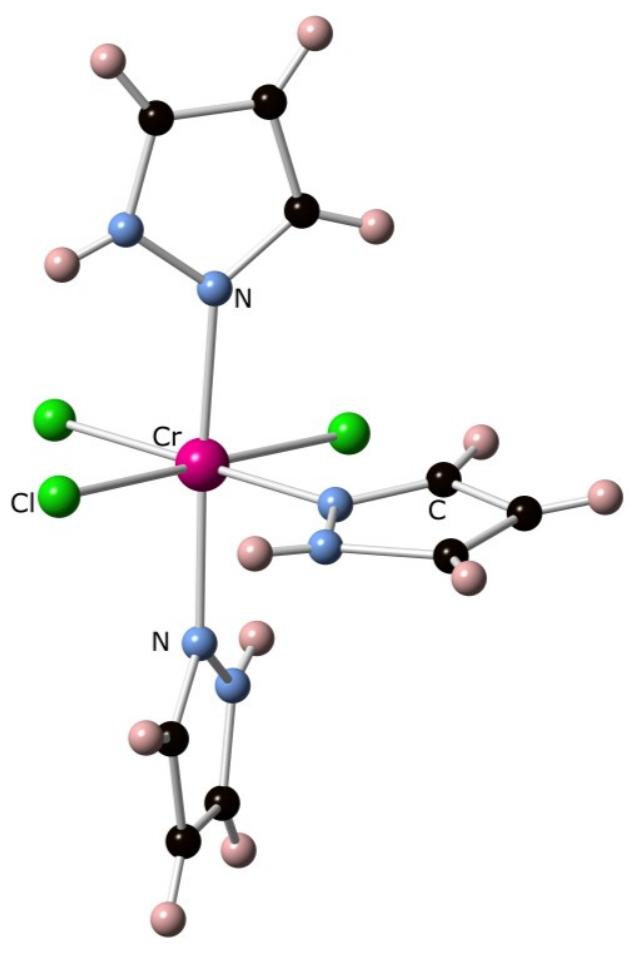

Figure 11. Ball-and-stick representation of $\left[m e r-\mathrm{CrCl}_{3}(\mathrm{pzH})_{3}\right](\mathbf{1})$. 


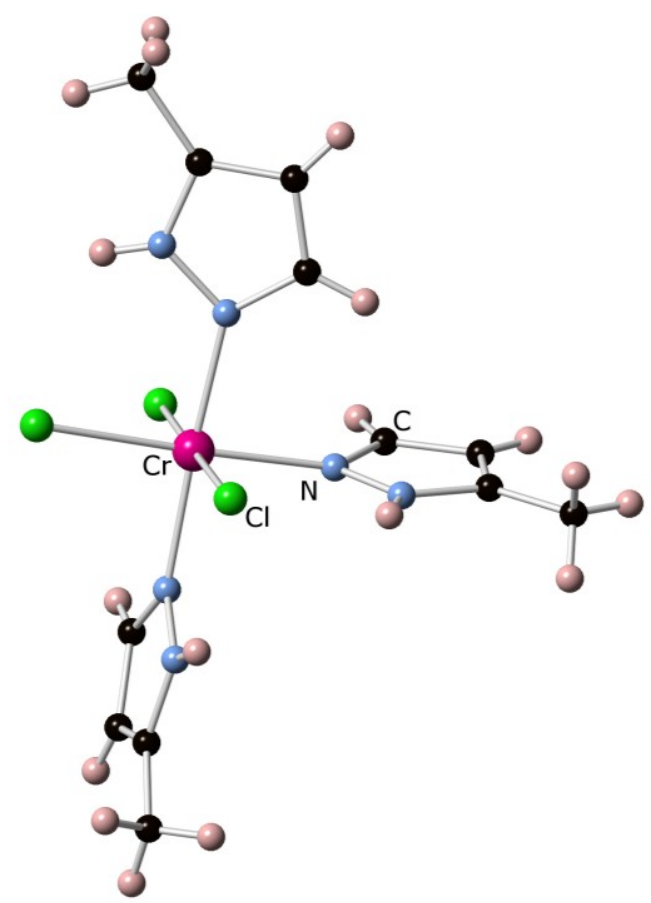

Figure 12. Ball-and-stick representation of $\left[\mathrm{mer}-\mathrm{CrCl}_{3}(3-\mathrm{Me}-\mathrm{pzH})_{3}\right](\mathbf{2})$.

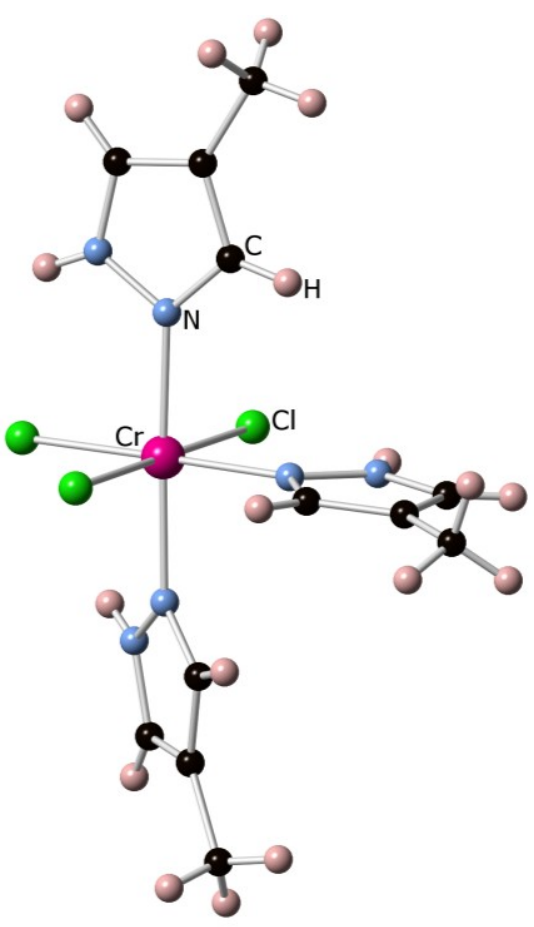

Figure 13. Ball-and-stick representation of $\left[m e r-\mathrm{CrCl}_{3}(4-\mathrm{Me}-\mathrm{pzH})_{3}\right]$ (3). 


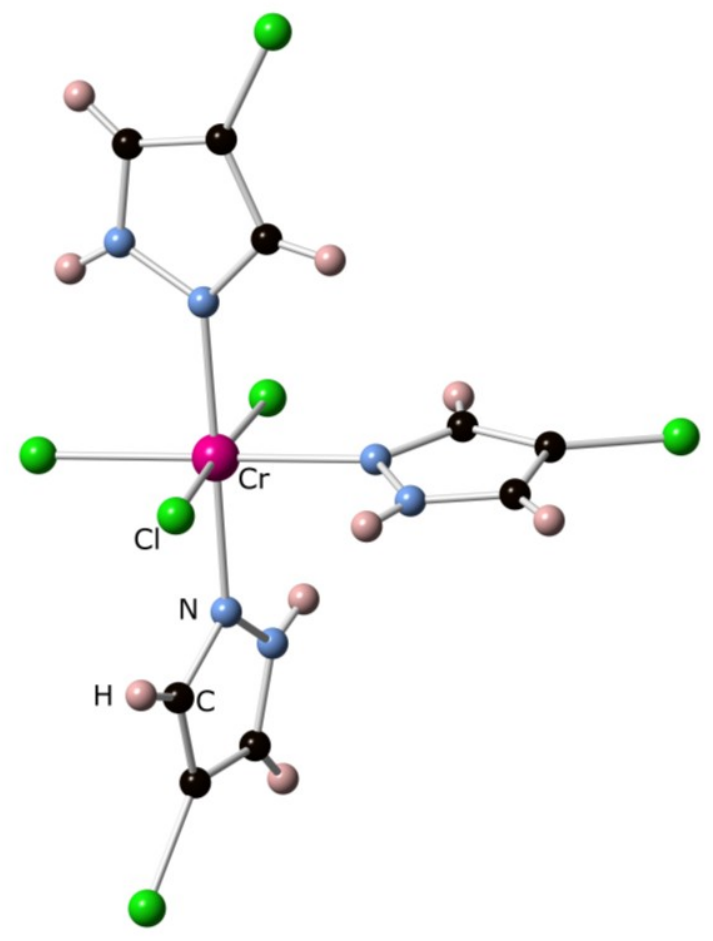

Figure 14. Ball-and-stick representation of $\left[\right.$ mer $\left.-\mathrm{CrCl}_{3}(4-\mathrm{Cl}-\mathrm{pzH})_{3}\right](4)$.

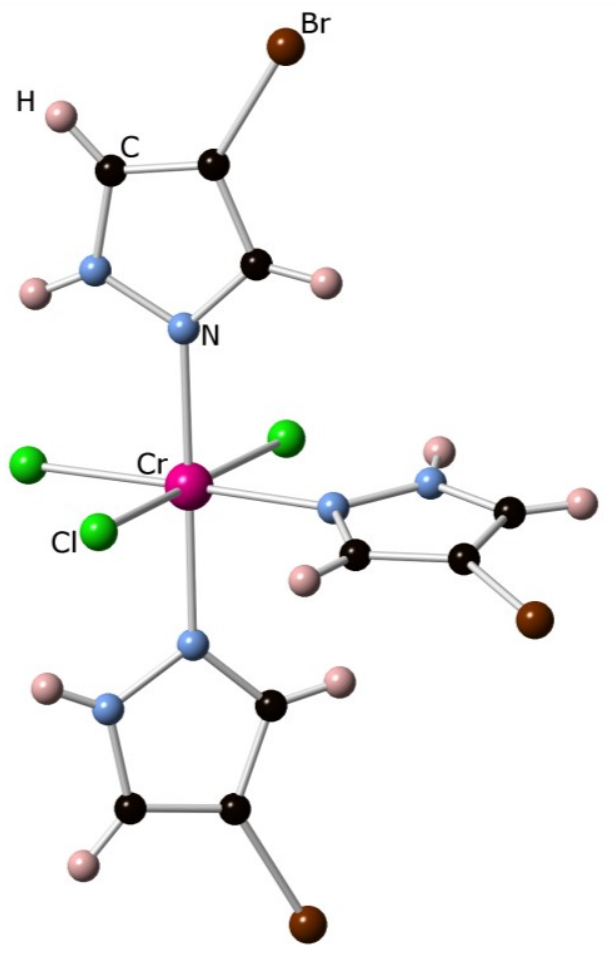

Figure 15. Ball-and-stick representation of $\left[\right.$ mer $\left.-\mathrm{CrCl}_{3}(4-\mathrm{Br}-\mathrm{pzH})_{3}\right](\mathbf{5})$. 


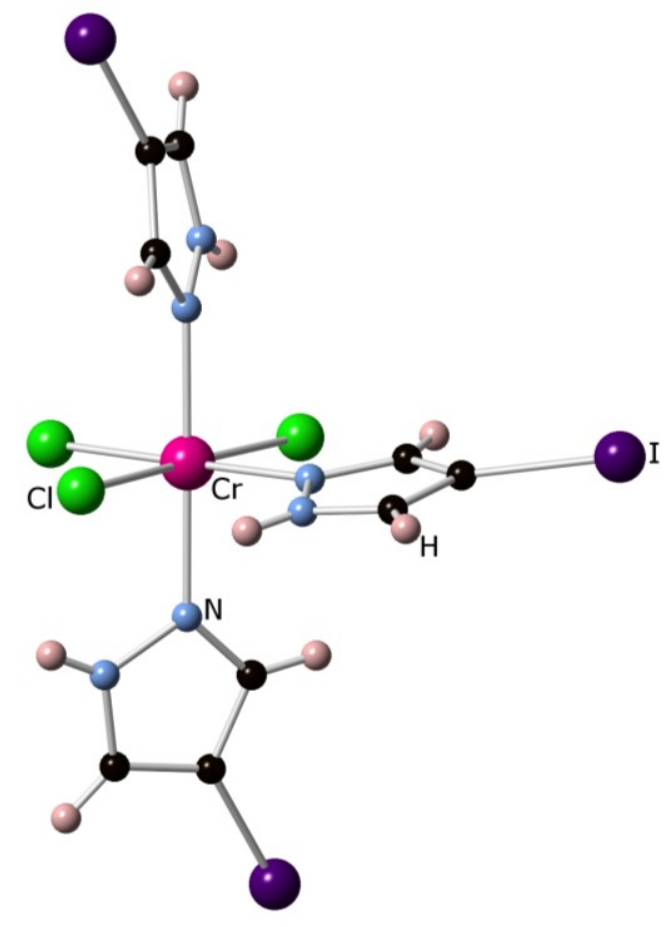

Figure 16. Ball-and-stick representation of $\left[\right.$ mer- $\left.\mathrm{CrCl}_{3}(4-\mathrm{I}-\mathrm{pzH})_{3}\right](\mathbf{6})$.

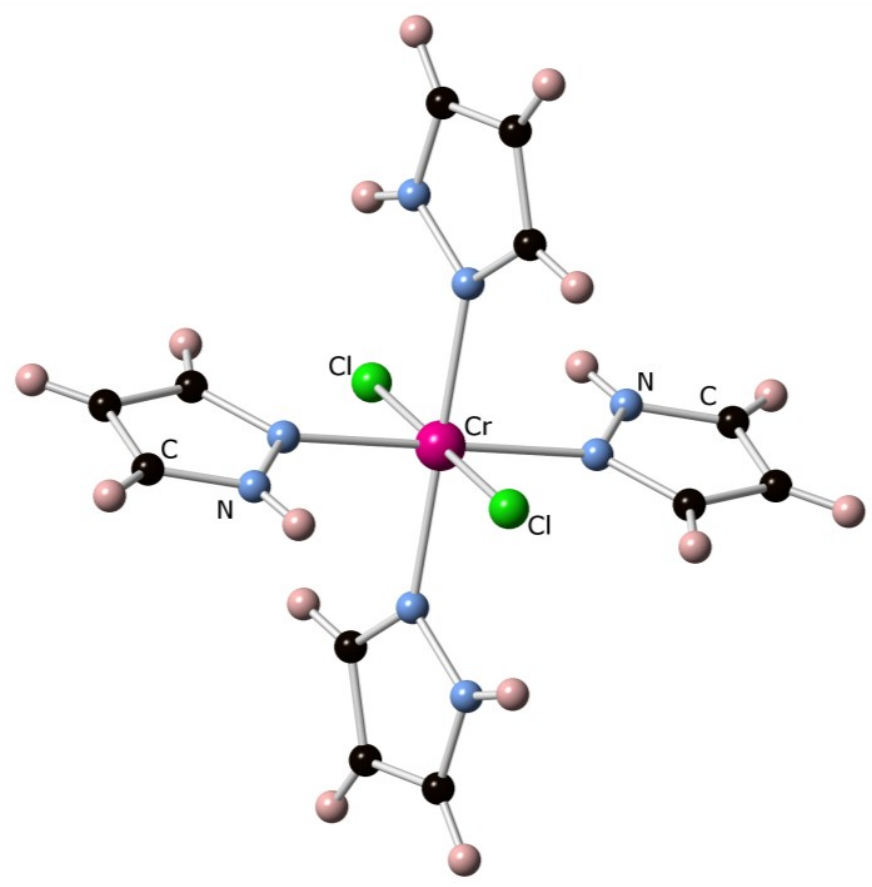

Figure 17. Ball-and-stick representation of $\left[\text { trans }-\mathrm{CrCl}_{2}(\mathrm{pzH})_{4}\right]^{+}$(7) cation. Chloride counter ion is omitted. 


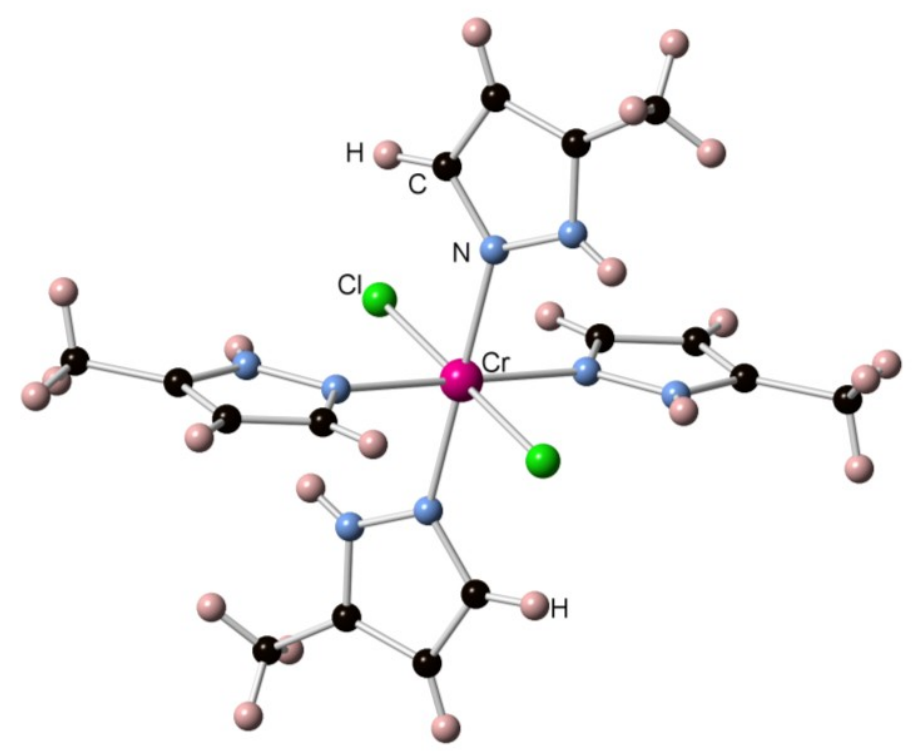

Figure 18. Ball-and-stick representation of $\left[\text { trans }-\mathrm{CrCl}_{2}(3-\mathrm{Me}-\mathrm{pzH})_{4}\right]^{+}(\mathbf{8})$ cation. Chloride counter ion is omitted.

Bond lengths and angles are within the expected range for $\mathrm{Cr}^{\mathrm{III}}$ complexes (Table 3, Table 4, Table 5). ${ }^{66,67}$ For all the $m e r-\mathrm{Cr}^{\mathrm{III}}$ complexes, the $\mathrm{Cr}-\mathrm{N}$ bonds trans to a halogen atom are longer than those trans to a pyrazole, similar to the analogous mer$\left[\mathrm{FeCl}_{3}(\mathrm{pz} * \mathrm{H})_{3}\right] .{ }^{58} \mathrm{~A}$ short $\mathrm{H}-$ bond distance is observed between $\mathrm{N}-\mathrm{H} \cdots \mathrm{O}$ in complex 4 with a THF interstitial solvent molecule in the crystal lattice.

Table 3. Selected bond lengths ( $\AA$ ) for 1-6.

\begin{tabular}{ccccccc} 
& \multicolumn{6}{c}{ Compound } \\
\cline { 2 - 7 } Bond & $\mathbf{1}$ & $\mathbf{2}$ & $\mathbf{3}$ & $\mathbf{4}$ & $\mathbf{5}$ & $\mathbf{6}$ \\
\hline $\mathrm{Cr}-\mathrm{Cl}$ & $2.3231(4)^{\mathrm{a}}$ & $2.371(2)^{\mathrm{a}}$ & $2.325(2)^{\mathrm{a}}$ & $2.3472(9)^{\mathrm{a}}$ & $2.310(2)^{\mathrm{a}}$ & $2.310(1)^{\mathrm{a}}$ \\
& $2.3242(7)^{\mathrm{b}}$ & $2.312(2)^{\mathrm{a}}$ & $2.321(2)^{\mathrm{a}}$ & $2.3051(9)^{\mathrm{a}}$ & $2.319(2)^{\mathrm{a}}$ & $2.314(1)^{\mathrm{a}}$ \\
& & $2.329(2)^{\mathrm{b}}$ & $2.327(2)^{\mathrm{b}}$ & $2.3228(9)^{\mathrm{b}}$ & $2.330(2)^{\mathrm{b}}$ & $2.307(1)^{\mathrm{b}}$ \\
$\mathrm{Cr}-\mathrm{N}$ & $2.072(2)^{\mathrm{a}}$ & $2.076(3)^{\mathrm{a}}$ & $2.064(4)^{\mathrm{a}}$ & $2.078(2)^{\mathrm{a}}$ & $2.069(3)^{\mathrm{a}}$ & $2.061(4)^{\mathrm{a}}$ \\
& $2.092(2)^{\mathrm{b}}$ & $2.078(3)^{\mathrm{a}}$ & $2.053(4)^{\mathrm{a}}$ & $2.077(2)^{\mathrm{a}}$ & $2.062(3)^{\mathrm{a}}$ & $2.063(4)^{\mathrm{a}}$ \\
& & $2.092(3)^{\mathrm{b}}$ & $2.070(4)^{\mathrm{b}}$ & $2.108(2)^{\mathrm{b}}$ & $2.091(3)^{\mathrm{b}}$ & $2.091(4)^{\mathrm{b}}$ \\
\hline
\end{tabular}

${ }^{\mathrm{a}}$ trans- $\mathrm{Cl}-\mathrm{Cr}-\mathrm{Cl}$, or trans- $\mathrm{N}-\mathrm{Cr}-\mathrm{N}$ bonds

${ }^{b}$ trans-N-Cr-Cl bonds 
Table 4. Selected bond angles $\left(^{\circ}\right)$ for 1-6.

Compound

\begin{tabular}{lcccccc} 
Bond & $\mathbf{1}$ & $\mathbf{2}$ & $\mathbf{3}$ & $\mathbf{4}$ & $\mathbf{5}$ & $\mathbf{6}$ \\
\cline { 2 - 7 } Angle & & & & & & \\
\hline N-Cr-N & $87.93(4)$ & $87.3-90.5$ & $88.2-89.4$ & $90.1-90.9$ & $88.9-90.1$ & $89.9-91.5$ \\
& $175.85(8)$ & $176.8(1)$ & $177.5(2)$ & $178.48(7)$ & $178.6(1)$ & $178.2(2)$ \\
Cl-Cr-N & $89.40(4)$ & $88.4-91.7$ & $89.4-91.7$ & $87.7-91.1$ & $87.9-91.4$ & $87.9-91.5$ \\
& 180.0 & $177.8(1)$ & $178.5(1)$ & $178.57(5)$ & $179.1(1)$ & $179.0(1)$ \\
Cl-Cr-Cl & $90.65(1)$ & $89.9-91.4$ & $89.1-91.8$ & $91.0-93.2$ & $90.5-92.1$ & $91.3-91.4$ \\
& $178.69(3)$ & $178.66(4)$ & $179.13(6)$ & $175.71(2)$ & $177.24(5)$ & $177.30(5)$
\end{tabular}

Table 5. Selected bond lengths $(\AA)$ and angles $\left({ }^{\circ}\right)$ for 7-8.

\begin{tabular}{lcc} 
& \multicolumn{2}{c}{ Compound } \\
\cline { 2 - 3 } Bond Lengths & $\mathbf{7}$ & $\mathbf{8}$ \\
\hline Cr-Cl & $2.3102(7)$ & $2.2939(6)$ \\
& $2.3013(7)$ & \\
Cr-N & $2.066(2)$ & $2.066(2)$ \\
& $2.065(2)$ & $2.079(2)$ \\
& $2.068(2)$ & \\
& $2.072(2)$ & \\
\hline Bond Angle & \multicolumn{3}{|}{} \\
\hline N-Cr-N & 180.0 & 180.0 \\
& $88.2-91.8$ & $89.9-90.1$ \\
Cl-Cr-N & $89.2-90.9$ & $89.2-90.7$ \\
Cl-Cr-Cl & 180.0 & 180.0
\end{tabular}

Intermolecular distance less than the sum of the van der Waals radii for adjacent atoms are defined as bonding interactions. The sum of average van der Waals radii for selected atoms is listed in Table 6. Intermolecular hydrogen bonding interactions are observed for 1-6 that play major role on the crystal packing of the complexes. 
Table 6. Summarized observed van der Waals radii $(\AA) .{ }^{68}$

\begin{tabular}{cc} 
Bond & Sum of van der Waals Radii $(\AA)$ \\
\hline $\mathrm{H}-\mathrm{N}$ & 2.52 \\
$\mathrm{H}-\mathrm{Cl}$ & 2.81 \\
$\mathrm{H}-\mathrm{Br}$ & 2.92 \\
$\mathrm{H}-\mathrm{I}$ & 3.10 \\
$\mathrm{Cl}-\mathrm{Cl}$ & 3.50 \\
$\mathrm{Cl}-\mathrm{Br}$ & 3.62 \\
$\mathrm{Br}-\mathrm{Br}$ & 3.74 \\
$\mathrm{I}-\mathrm{Cl}$ & 3.79 \\
$\mathrm{I}-\mathrm{I}$ & 4.08
\end{tabular}

Halogen-halogen interactions give rise to close packing in complexes 4-6, exhibiting a bent, type $\mathrm{II}^{\dagger}, \mathrm{R}-\mathrm{X}_{\mathrm{a}} \cdots \mathrm{X}_{\mathrm{b}}$-R contact interaction $\left(\mathrm{X}=\right.$ halogen atom) ${ }^{69}$ The intermolecular distance between the halogen substituent of the pyrazole and a coordinated chlorine from an adjacent complex are less than the sum of their van der Waals radii, $\mathrm{Cl} 5 \cdots \mathrm{Cl} 6$ distance and $\mathrm{C} 5-\mathrm{Cl} 5 \cdots \mathrm{Cl}$ angle in 4 are 3.299(1) $\AA$ and $173.8(2)^{\circ}$, respectively.

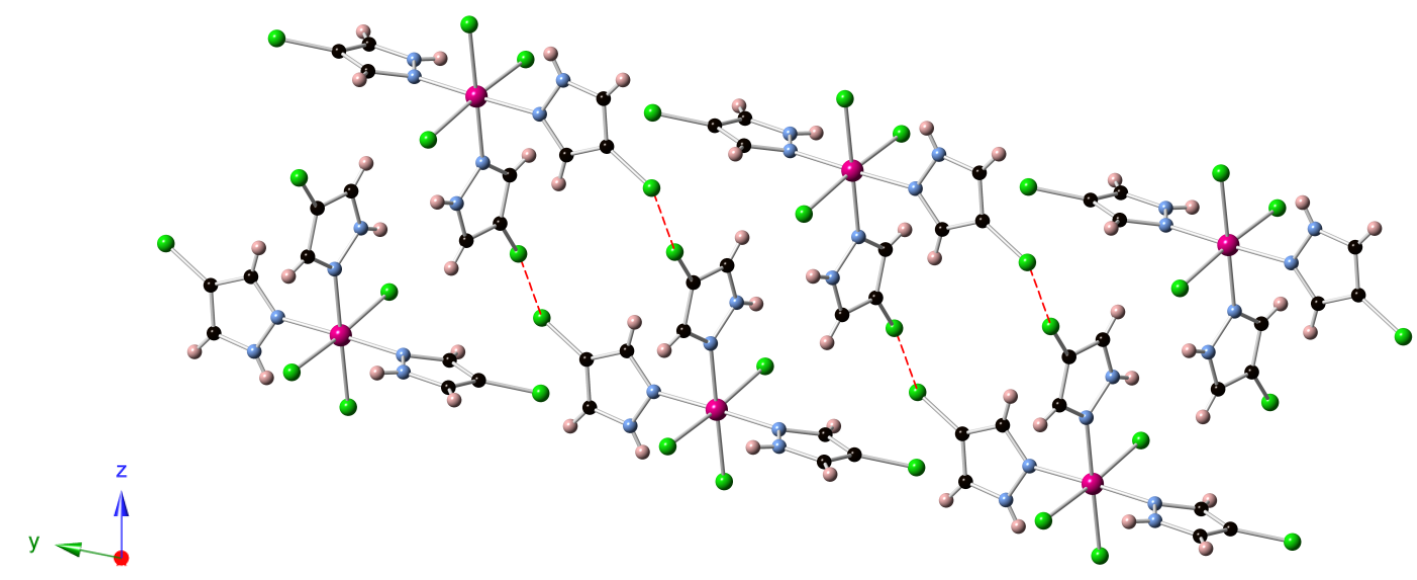

Figure 19. Illustration of halogen bonding between $\mathrm{Cl}$ atoms on complex 4 .

${ }^{\dagger}$ Contact interactions are classified as: type I $\left(\theta_{1}=\theta_{2}\right)$ and type II $\theta_{1} \approx 180^{\circ}$ and $\theta_{2} \approx 90^{\circ}$. $\left[\theta_{1}\left(\mathrm{R}-\mathrm{X}_{\mathrm{a}} \cdots \mathrm{X}_{\mathrm{b}}\right)\right.$; $\left.\theta_{2}\left(\mathrm{X}_{\mathrm{a}} \cdots \mathrm{X}_{\mathrm{b}}-\mathrm{R}\right)\right]$ 
Halogen bonging in $\mathbf{5}$ links two adjacent monomers, resulting in the 3D network manifested in the crystal packing diagram. Halogen bonding distances and angles are listed in Table 7. Halogen bonding between $\mathrm{Cl} \cdots \mathrm{Br}$ results in a $1 \mathrm{D}$ chain formation depicted in Figure 20. The $\mathrm{Br} \cdots \mathrm{Br}$ halogen bonding links two of the $1 \mathrm{D}$ chains resulting in a 3D network (Figure 21).

Table 7. Halogen-bond geometry for $\mathbf{5} .\left(\AA,{ }^{\circ}\right)$.

\begin{tabular}{lll}
$\mathrm{D}-\mathrm{X} \cdots \mathrm{Y}$ & $\mathrm{d}(\mathrm{X}-\mathrm{Y}) / \AA$ & $\mathrm{D}-\mathrm{X}-\mathrm{Y} /{ }^{\circ}$ \\
\hline $\mathrm{C} 2-\mathrm{Br} 1 \cdots \mathrm{Cl} 2^{\mathrm{a}}$ & $3.492(3)$ & $140.7(1)$ \\
$\mathrm{C} 5-\mathrm{Br} 2 \cdots \mathrm{Br} 2^{\mathrm{b}}$ & $3.658(3)$ & $138.0(1)$ \\
\hline Symmetry codes: (a) $\mathrm{x}, 1+\mathrm{y}, \mathrm{z} ;$ (b) $-\mathrm{x}, 2-\mathrm{y}, 1-\mathrm{z}$
\end{tabular}

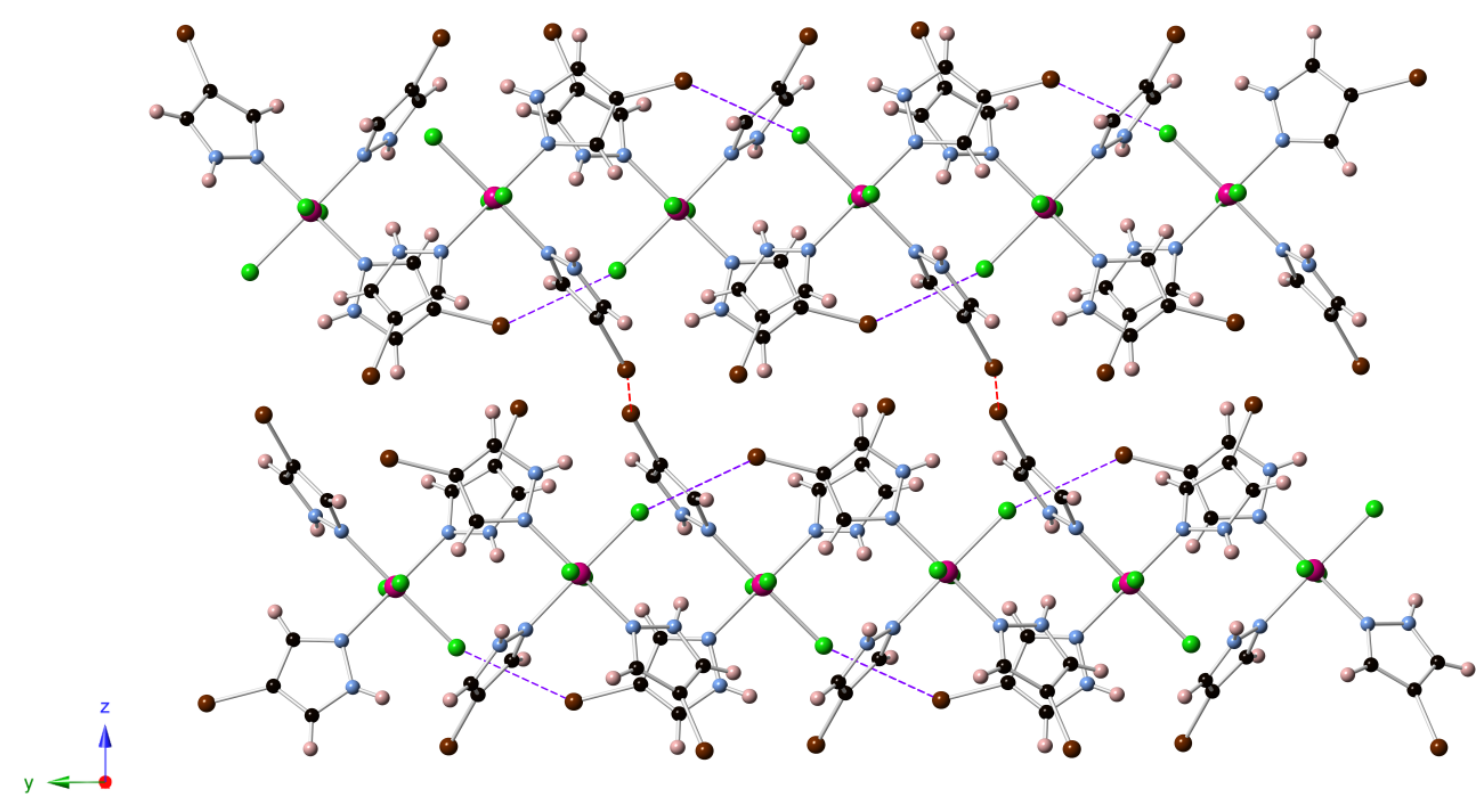

Figure 20. Illustration of crystal packing of 5, showing 1D chains linked by halogen bonding. 


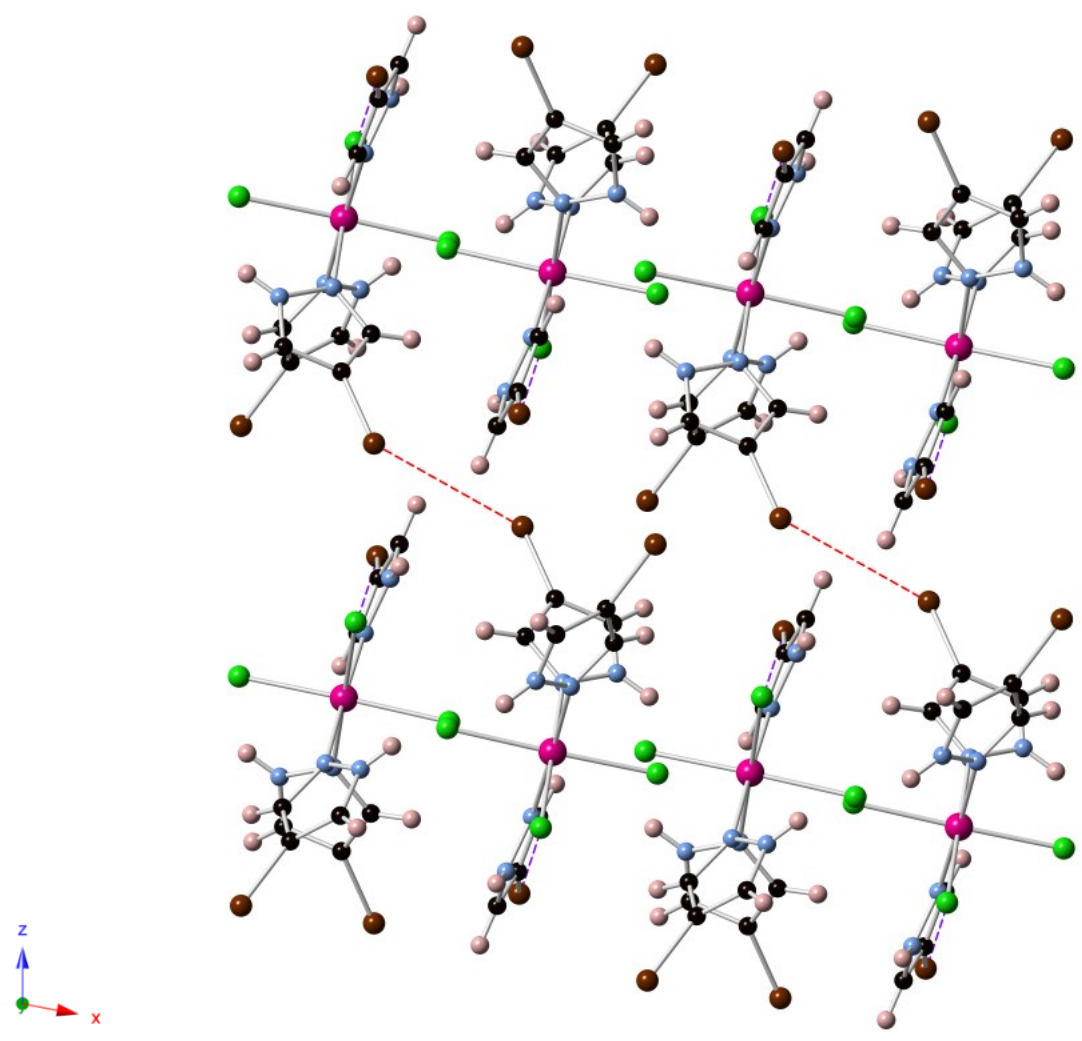

Figure 21. Illustration of crystal packing of 5, showing two 1D chains linked by halogen bonding.

Distances and angles for halogen bonding in $\mathbf{6}$ are shown in Table 8. Bifurcated halogen bonds are noted between $\mathrm{Cl1}$ and I1/I3. Halogen bonding provides a linkage between adjacent monomer molecules generating a 2D network.

Table 8. Halogen-bond geometry for $\mathbf{6} .\left(\AA,{ }^{\circ}\right)$.

\begin{tabular}{lll}
$\mathrm{D}-\mathrm{X} \cdots \mathrm{Y}$ & $\mathrm{d}(\mathrm{X}-\mathrm{Y}) / \AA$ & $\mathrm{D}-\mathrm{X}-\mathrm{Y} /{ }^{\circ}$ \\
\hline $\mathrm{C} 2-\mathrm{I} 1 \cdots \mathrm{Cl1} 1^{\mathrm{a}, \mathrm{b}}$ & 3.523 & $145.9(2)$ \\
$\mathrm{C} 5-\mathrm{I} 2 \cdots \mathrm{Cl} 3^{\mathrm{b}, \mathrm{c}}$ & 3.487 & $168.5(1)$ \\
$\mathrm{C} 8-\mathrm{I} 3 \cdots \mathrm{Cl1} 1^{\mathrm{b}, \mathrm{c}}$ & 3.526 & $167.9(2)$ \\
\hline Symmetry codes: (a) $2-\mathrm{x}, 1-\mathrm{y}, 1-\mathrm{z}$ & $;$ (b) $\mathrm{x}, \mathrm{y}, \mathrm{x} ;$ (c) $\mathrm{x},-1+\mathrm{y}, \mathrm{z}$
\end{tabular}




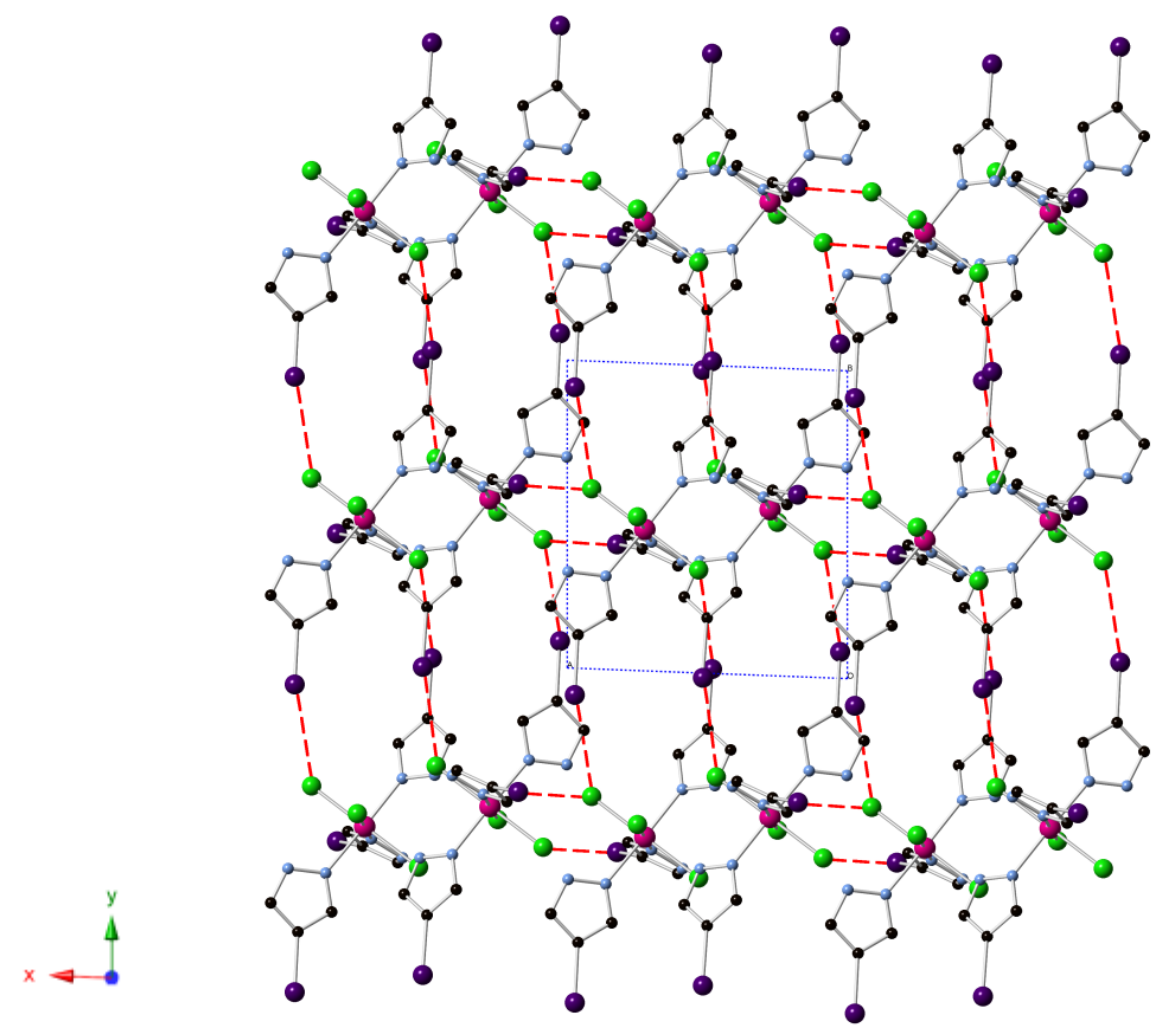

Figure 22. Illustration of crystal packing of 6 , showing halogen bonding. THF solvent molecule and hydrogen atoms were omitted for clarity.

\subsubsection{Electrochemistry and electronic absorption spectra of $\mathrm{Cr}^{\mathrm{III}}$ monomers}

Chromium monomers with formula $\left[\right.$ mer- $\left.\mathrm{CrCl}_{3} \mathrm{~L}_{3}\right](\mathrm{L}=\mathrm{pzH}, 4-\mathrm{Me}-\mathrm{pzH}, 3-\mathrm{Me}-$ pzH, 4-Cl-pzH, 4-I-pzH and, 4-Br-pzH) were studied electrochemically, showing no reversible redox processes within the $-500 \mathrm{mV}$ to $1500 \mathrm{mV}$ redox potential window. The UV-Vis spectra of the complexes show no significant differences in the absorption peaks with variation of the pyrazole substituent. For all compounds, a broad charge transfer band is observed between 200 - $280 \mathrm{~nm}$. Charge transfer bands are spin-allowed and Laporte-allowed, in contrast to the Laporte-forbidden d-d transitions bands, which causes marked intensity differences between them. Two d-d transition bands were observed from $380-800 \mathrm{~nm}$, listed in Table 9. 


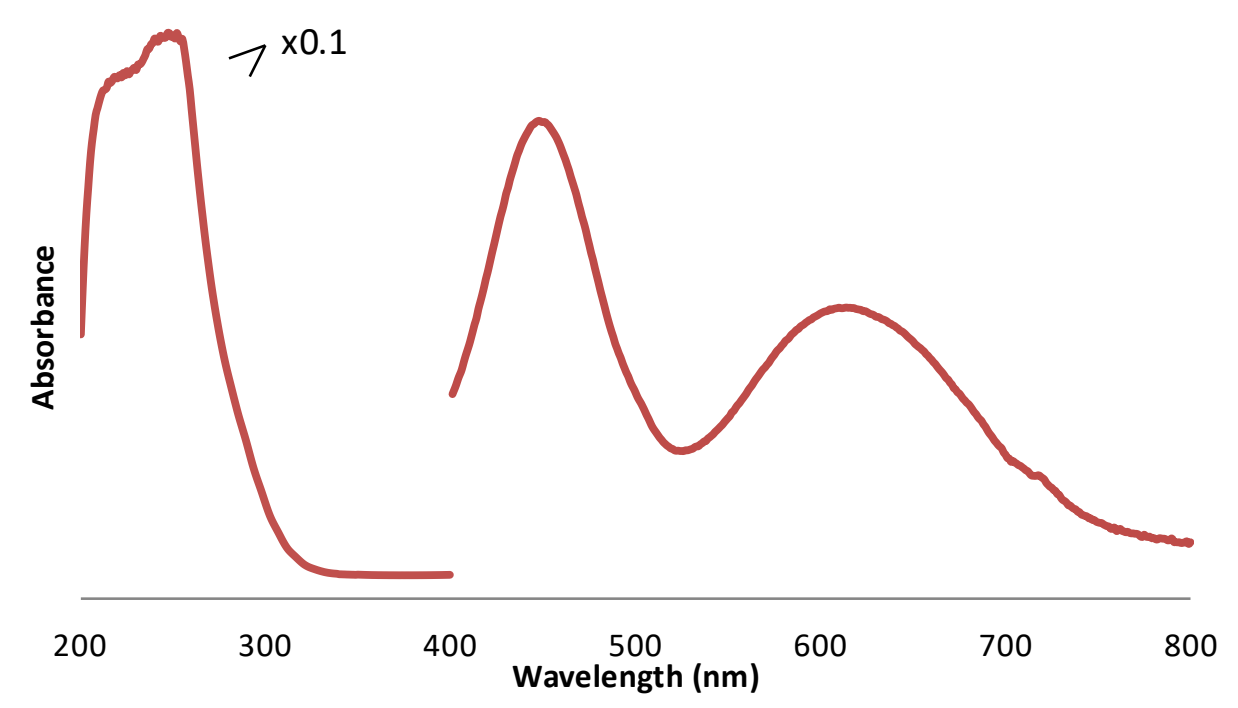

Figure 23. UV-Vis of $\left[\right.$ mer- $\left.\mathrm{CrCl}_{3}(\mathrm{pzH})_{3}\right](\mathbf{1})\left(6.4 \times 10^{-4} \mathrm{M}\right)$ in $\mathrm{MeOH}$.

Table 9. Wavelength for d-d transitions for complexes 1-6.

\begin{tabular}{crc} 
Complex & $\lambda_{\max 1}(\mathrm{~nm}) / \mathrm{v}_{2}\left(\mathrm{~cm}^{-1}\right)$ & $\lambda_{\max 2}(\mathrm{~nm}) / \mathrm{v}_{1}, 10 D q\left(\mathrm{~cm}^{-1}\right)$ \\
\hline $\mathbf{1}$ & $448 / 22321$ & $614 / 16287$ \\
$\mathbf{2}$ & $446 / 22421$ & $608 / 16447$ \\
$\mathbf{3}$ & $439 / 22779$ & $599 / 16695$ \\
$\mathbf{4}$ & $464 / 21552$ & $638 / 15674$ \\
$\mathbf{5}$ & $451 / 22173$ & $626 / 15974$ \\
$\mathbf{6}$ & $452 / 22173$ & $618 / 16181$ \\
$\mathbf{7}$ & $410 / 24390$ & $546 / 18315$ \\
$\mathbf{8}$ & $409 / 24450$ & $555 / 18018$
\end{tabular}

Crystal field theory predicts that the Russell-Saunders ground state for free ion $\mathrm{Cr}^{\mathrm{III}}$, ${ }^{4} \mathrm{~F}$, splits into: ${ }^{4} \mathrm{~T}_{1 \mathrm{~g}},{ }^{4} \mathrm{~T}_{2 \mathrm{~g}}$, and ${ }^{4} \mathrm{~A}_{2 \mathrm{~g}}$ substates for octahedral environment. ${ }^{70}$ Ligand coordination lowers the symmetry of the metal center, causing loss of degeneracy as depicted in Scheme 9. Two spin-allowed bands corresponding to ${ }^{4} \mathrm{~A}_{2 \mathrm{~g}}-{ }^{4} \mathrm{~T}_{2 \mathrm{~g}}(\mathrm{~F})\left(\mathrm{v}_{1}\right)$ and ${ }^{4} \mathrm{~A}_{2 \mathrm{~g}}-{ }^{4} \mathrm{~T}_{1 \mathrm{~g}}(\mathrm{~F})\left(\mathrm{v}_{2}\right)$ transitions are observed. The lowest energy transition $\left(v_{1}\right)$ corresponds to $10 \mathrm{Dq}$, the ligand field splitting energy. ${ }^{71}$ 


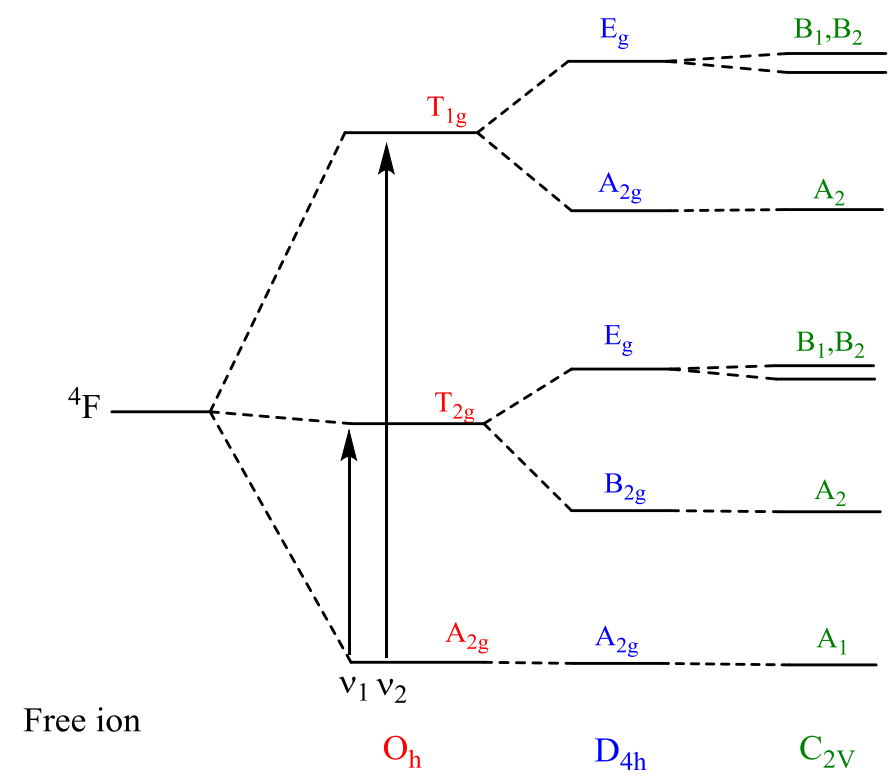

Scheme 9. Splitting of the ground state term ${ }^{5} \mathrm{~F}$ ( $\mathrm{d}^{3}$ free ion) (arrows show spin allowed transitions in an octahedral $\left(\mathrm{O}_{\mathrm{h}}\right)$ environment).

Additional pyrazole ligand in $\mathbf{7}$ causes shifting to higher energy, compared to $\mathbf{1}$, which is consistent with the stronger ligand field of an additional nitrogen atom. Similar energy shifts have been observed for $\mathrm{Cr}^{\mathrm{II}} \mathrm{L}_{2} \mathrm{Cl}_{2}$ and $\mathrm{Cr}^{\mathrm{II}} \mathrm{L}_{4} \mathrm{Cl}_{2}$ ( $\mathrm{L}=$ pyrazole, dimethylpyrazole and imidazole). ${ }^{64}$ Solvent effect on charge transfer bands have been experimentally and theoretically studied. ${ }^{72,73}$ Absorption spectra in various solvents were recorded for complex 1, where an inverse linear dependence of charge transfer (CT) energy and solvent dielectric constant is obtained, same as other chromium(III) complexes (Figure 24). ${ }^{72}$ 


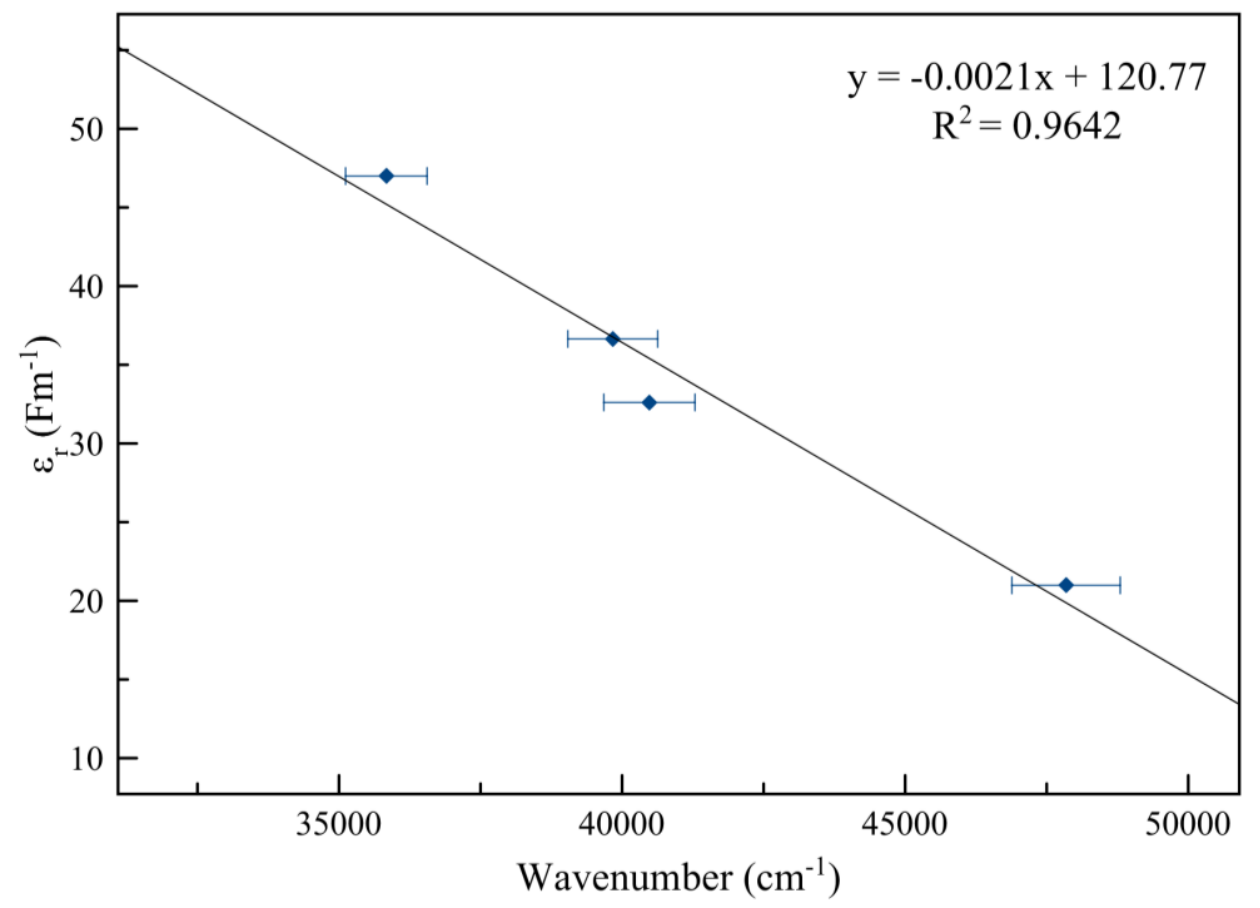

Figure 24. Dielectric constant $\left(\mathrm{Fm}^{-1}\right)$ of solvent as a function of charge transfer (CT) band energy $\left(\mathrm{cm}^{-1}\right)$ for complex 1 .

\subsubsection{Nuclear magnetic resonance and electron paramagnetic resonance}

Paramagnetic complexes have small electron spin relaxation times that causes a resonance broadening-flattening in the NMR and sometimes the spectrum disappears. ${ }^{74}$ The effect of the paramagnetic environment to the spin relaxation is timescale dependent, which is reduced when the lifetime of the electron spin relaxation is short, allowing to record a NMR spectrum. ${ }^{54}$ Electron paramagnetic resonance (EPR) is a technique that probes transitions between electron-spin quantum states $\left(\mathrm{m}_{S}\right)$, rather than nuclear-spin quantum states $\left(\mathrm{m}_{I}\right)$ observed by NMR. ${ }^{75}$ Electron paramagnetic resonance is used to study the spin-state in paramagnetic complexes. ${ }^{76}$ The technique is used to characterize spin-state, to confirm the spin-state determined by magnetic susceptibility, or to 
determine the localization or delocalization of spin in a metal complex. For some compounds with intermediate electron-spin relaxation rate, both the NMR and the EPR are possible to record, because the relaxation is slow enough for an EPR and fast enough for NMR spectrum to be recorded. ${ }^{77}$

\subsubsection{Nuclear magnetic resonance of $\mathrm{Cr}^{\mathrm{III}}$ monomers}

Chromium(III), $\mathrm{d}^{3}$ ions have an electronic spin of $\mathrm{S}=3 / 2$ and typically a very small zero-field splitting parameter (D); the electronic configuration determines their relaxation properties. The most efficient relaxation mechanism for high-spin $\mathrm{Cr}^{3+}$ complexes is often the modulation of transient zero-field splitting (ZFS) ${ }^{78}$ The ZFS has strong influence on the resonance of nuclear spins in solution, this effect has been theoretically studied for transition metal complexes. ${ }^{79,80}$

Some mononuclear chromium(III) complexes with pincer-type ligands containing a central pyridine moiety have no detectable signals in the in the range from -300 to $+300 \mathrm{ppm}$, due to their fast relaxation rate. ${ }^{81}$ In the case of complex $\left[\mathrm{mer}-\mathrm{CrCl}_{3}(\mathrm{pzH})_{3}\right]$ (1), NMR signals were observed. Spectra of 1 should contain two distinct pyrazole environments, one resonance for the protons of the pyrazoles trans to each other and the other for the pyrazole in the cis position. Unbound pyrazole (pzH) shows singlet resonance $12.82 \mathrm{ppm}$ for $\mathrm{H}^{1}-\mathrm{N}$, doublet at $7.59 \mathrm{ppm}$ for $\mathrm{H}^{3 / 5}$, and a triplet at $6.25 \mathrm{ppm}$ for $\mathrm{H}^{4}$. Unlike free pyrazole, $\mathrm{H}^{3}$ and $\mathrm{H}^{5}$ on the mer-Cr ${ }^{\mathrm{III}}$ complex are not equivalent due to the metal coordination; a total of eight resonances should appear on the NMR for complex 1. 
Contrary to the expected, 1 showed fewer resonances in acetone- $\mathrm{d}_{6}$ and acetonitrile- $\mathrm{d}_{3}$. Spectra of 1 showed peaks at $7.60 \mathrm{ppm}$ and $6.30 \mathrm{ppm}$ with integration 1:0.5, respectively. Line broadening and signal/noise ratio of the observed peak at -9.00 ppm causes integration problems. The broad peak of $\mathbf{1}$ at $-9.00 \mathrm{ppm}$ is absent in the spectrum 3, suggesting assignment to the $\mathrm{H}^{4}$ proton (Figure 25). In complex $\mathbf{3}$, a new resonance at $2.97 \mathrm{ppm}$, corresponds to the 4-Me group. The NMR spectra of complexes 4, 5 and $\mathbf{6}$ are depicted on Figure 26. Complex $\mathbf{4}$ and $\mathbf{5}$ have two resonances, whereas $\mathbf{6}$ showed one distinct peak. ${ }^{\ddagger}$

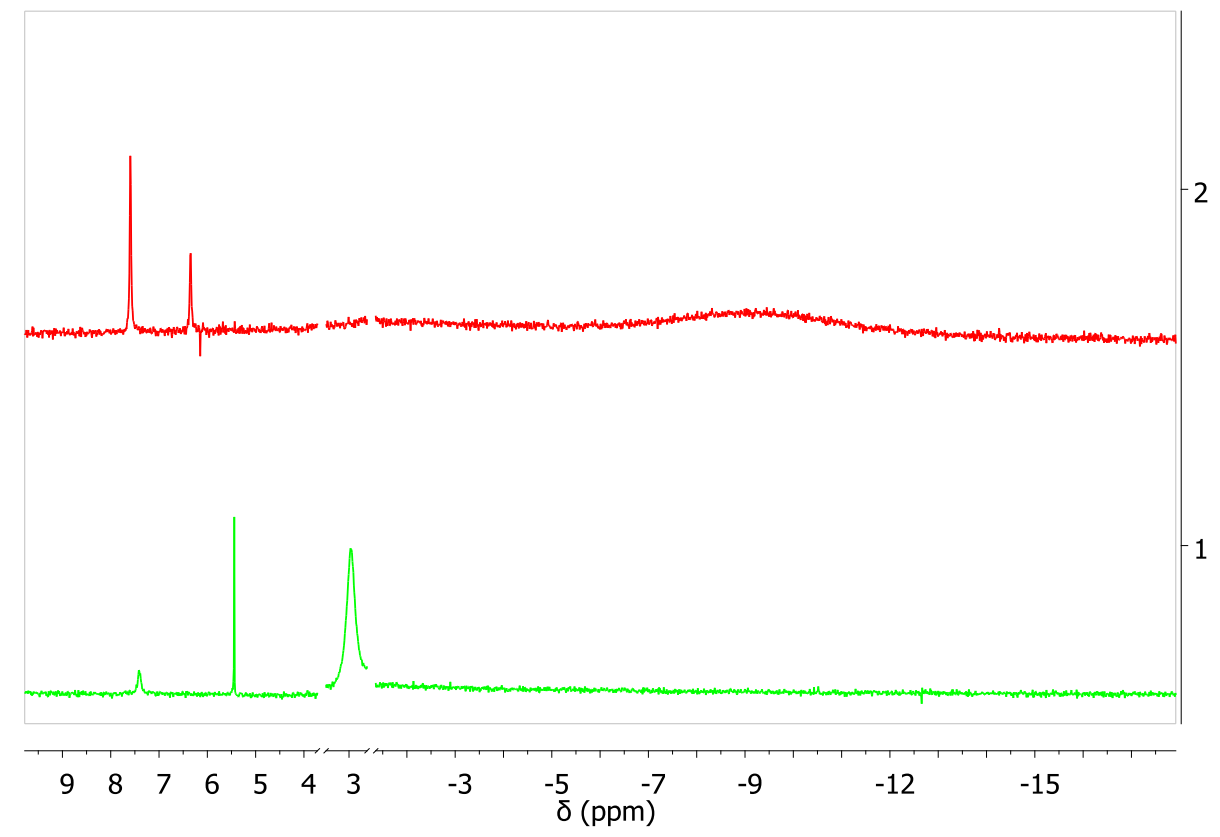

Figure 25. ${ }^{1} \mathrm{H}$ NMR of complex $\mathbf{1}$ (red) and 3 (green) in Acetonitrile-d $\mathrm{d}_{3}$ at $400 \mathrm{MHz}$. Spectra was referenced to the residual solvent proton resonance.

\footnotetext{
${ }^{\ddagger}$ Complex $\left[\right.$ mer- $\left.\mathrm{CrCl}_{3}(3-\mathrm{Me}-\mathrm{pzH})_{3}\right](2)$ had poor solubility in acetone and acetonitrile, peak assignment was not successful.
} 


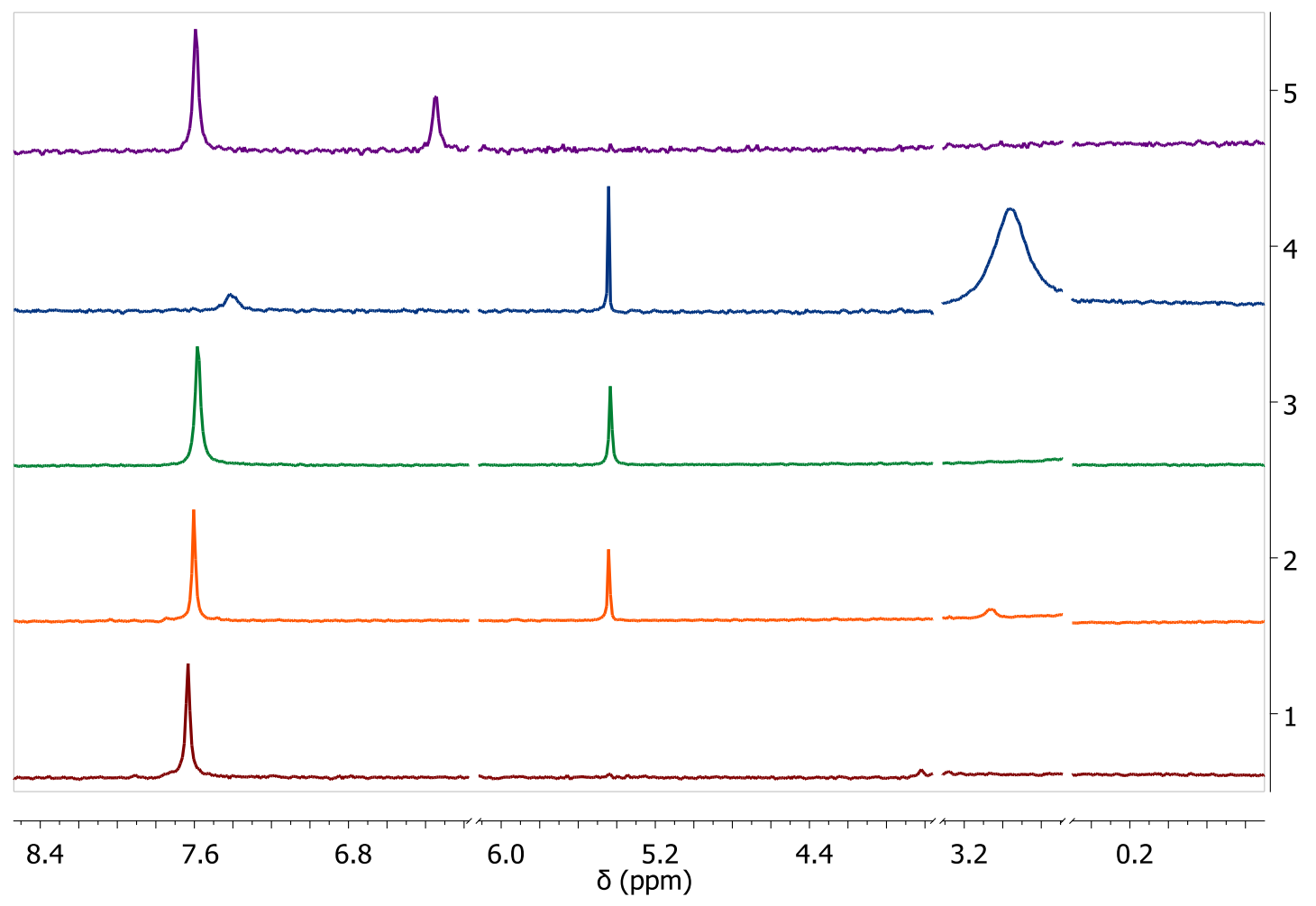

Figure 26. ${ }^{1} \mathrm{H}$ NMR of complex 1 (purple), 3 (blue), 4 (green), 5 (orange) and $\mathbf{6}$ (red) in Acetonitrile- $\mathrm{d}_{3}$ (red) at $400 \mathrm{MHz}$.

Paramagnetic upfield shift and line broadening in observed for complex 1. A similar case has been reported for the mononuclear chromium(III) tris-(8hydroxyquinolinate) complex that shows signals with large paramagnetic shifts to high frequencies and spectral broadening. ${ }^{82}$ Chemical shifts are determined by the nature of metal-ligand interaction. ${ }^{83}$ Shifts might come from either through-space dipolar interaction (pseudo-contact) or direct delocalization of electron density from the metal (contact shift). ${ }^{84}$ Contact and pseudo contact interactions cause a paramagnetic chemical shift effect on complex $\mathbf{1}$.

To further comprehend the NMR spectra of mononuclear chromium complexes, variable temperature NMR was recorded. Variable temperature NMR of paramagnetic 
complexes should show temperature dependence on chemical shift, while the line width should remain constant. ${ }^{85}$ Variable temperature NMR spectra of complex $\mathbf{1}$ were recorded in acetone- $\mathrm{d}_{6}$ solution over the $-60{ }^{\circ} \mathrm{C}$ to $+23{ }^{\circ} \mathrm{C}$ range (Figure 28). All resonances showed temperature dependent downfield shift upon cooling except for broad peak at $9.00 \mathrm{ppm}(\mathrm{F})$, which was shifted upfield upon cooling. The intensity of peak at $7.60 \mathrm{ppm}$ (AB) decreases and two new peaks at 7.40 (A) and 7.80 ppm (B) appeared. While the intensity of peak at $6.30 \mathrm{ppm}$ (D) decreases, the intensity of the $6.20 \mathrm{ppm}$ peak (C) increases upon cooling. The set of peaks around $7.30 \mathrm{ppm}$ (A and B) showed coalescence at room temperature. However, peaks at $6.20 \mathrm{ppm}(\mathrm{C})$ and $6.30 \mathrm{ppm}(\mathrm{D})$ remain at room temperature. Signals $\mathrm{E}$ and $\mathrm{F}$ are attributed to $\mathrm{H}^{4}$ of the pyrazole, peak assignments remains unclear because of line broadening, signals are absent for 4 . Curie temperature dependence is observed for proton signals for complex 1. Curie temperature dependence can be determined from the linear plot of chemical shift as a function of inverse temperature in $\mathrm{K}$ that should have positive slope for downfield shift and negative slope for upfield shift upon cooling (Figure 29). ${ }^{86,87}$

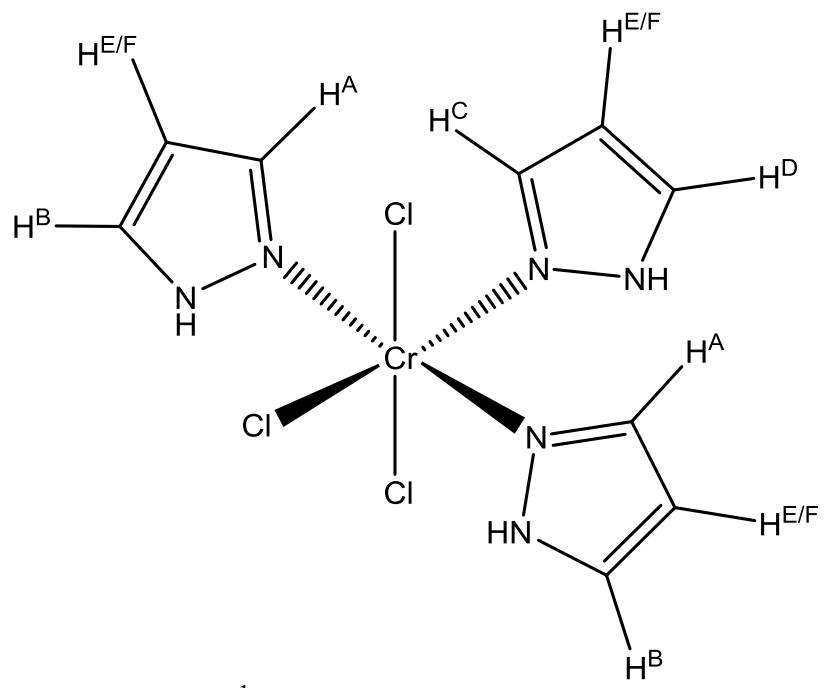

Figure 27. ${ }^{1} \mathrm{H}$ NMR peak assignment for $\mathbf{1}$. 


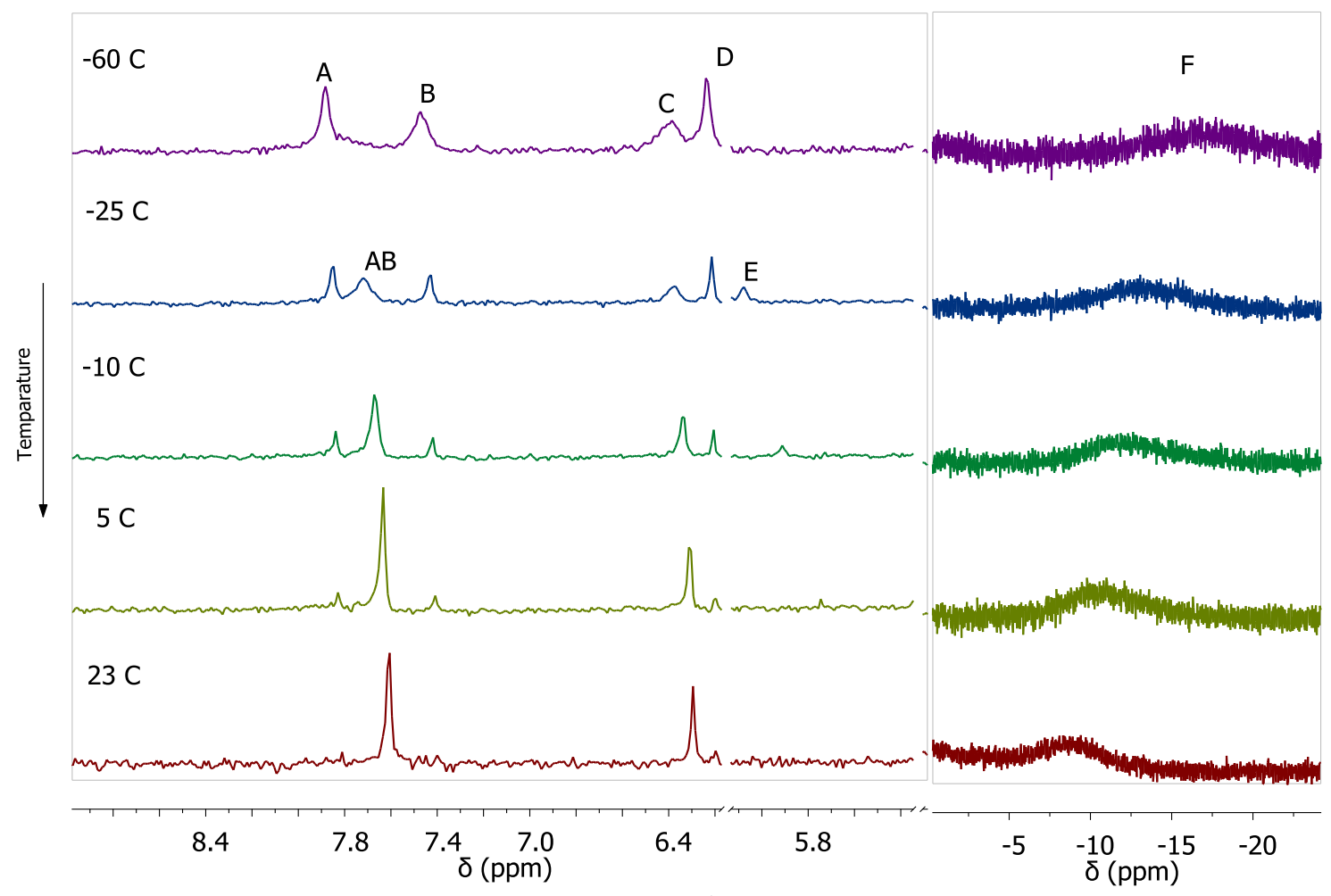

Figure 28. Variable temperature $400 \mathrm{MHz}{ }^{1} \mathrm{H}$ NMR of complex 1 in acetone- $\mathrm{d}_{6}$.

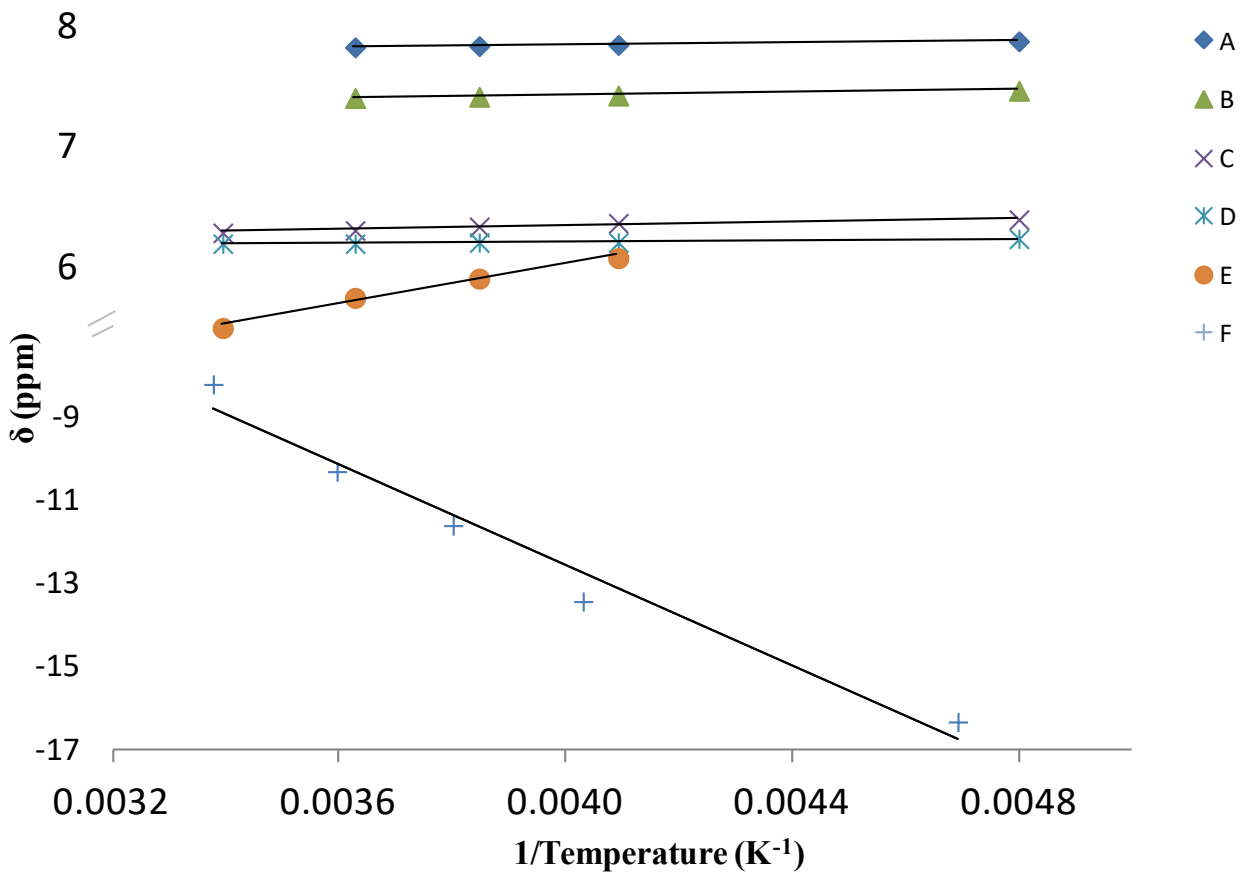

Figure 29. Temperature dependence of $\mathrm{H}$ chemical shifts of complex $\mathbf{1}$. 
Variable temperature spectra of complex 4 were recorded in acetone- $\mathrm{d}_{6}$ solution over the $-50{ }^{\circ} \mathrm{C}$ to $+23{ }^{\circ} \mathrm{C}$ range (Figure 31), showing similar behavior compared to $\mathbf{1}$. Disappearance of peaks E and F (of $\mathbf{1}$ ) is consistent with their assignment to the $\mathrm{H}^{4}$ of the pyrazole. Resonances showed temperature dependence, increasing the downfield chemical shift and $\Delta v$ (difference in chemical shift) upon cooling. The intensity of peak at $7.71 \mathrm{ppm}(\mathrm{AB})$ decreases while intensities of peaks at 7.45 (A) and $7.94 \mathrm{ppm}(\mathrm{B})$ increases. Intensity of peak at $5.61 \mathrm{ppm}$ (D) decreases and intensity of peak at $5.94 \mathrm{ppm}$ (C) increases. The set of peaks around $7.3 \mathrm{ppm}(\mathrm{A}$ and $\mathrm{B}$ ) did not show coalescence at room temperature. Coalescence temperature $\left(T_{c}\right)$ of peaks A and B is approximately 30 ${ }^{\circ} \mathrm{C}$. In contrast, the set of peaks at around $6 \mathrm{ppm}(\mathrm{C}$ and $\mathrm{D})$ showed $\mathrm{T}_{\mathrm{c}}$ at room temperature $\left(23^{\circ} \mathrm{C}\right)$.

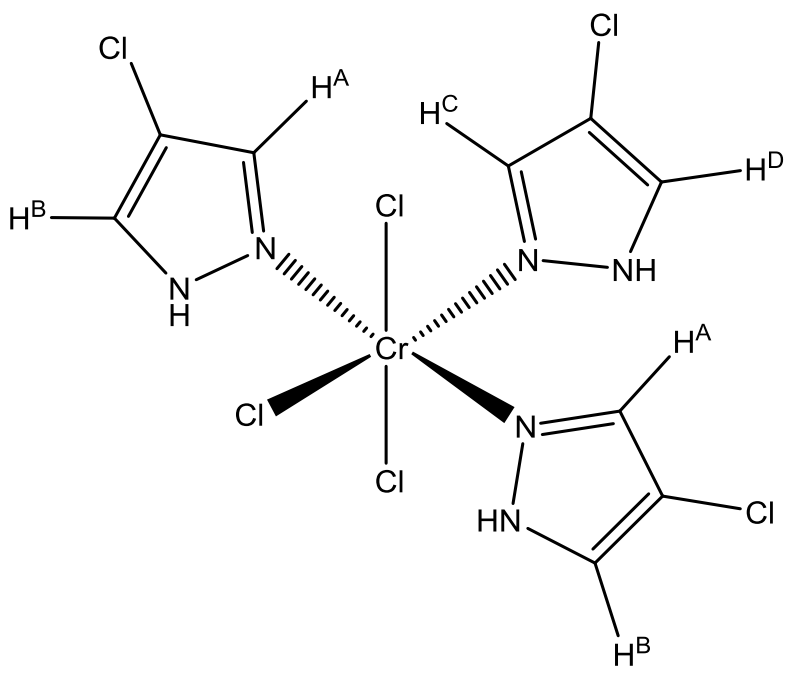

Figure 30. ${ }^{1} \mathrm{H}$ NMR peak assignment for 4. 


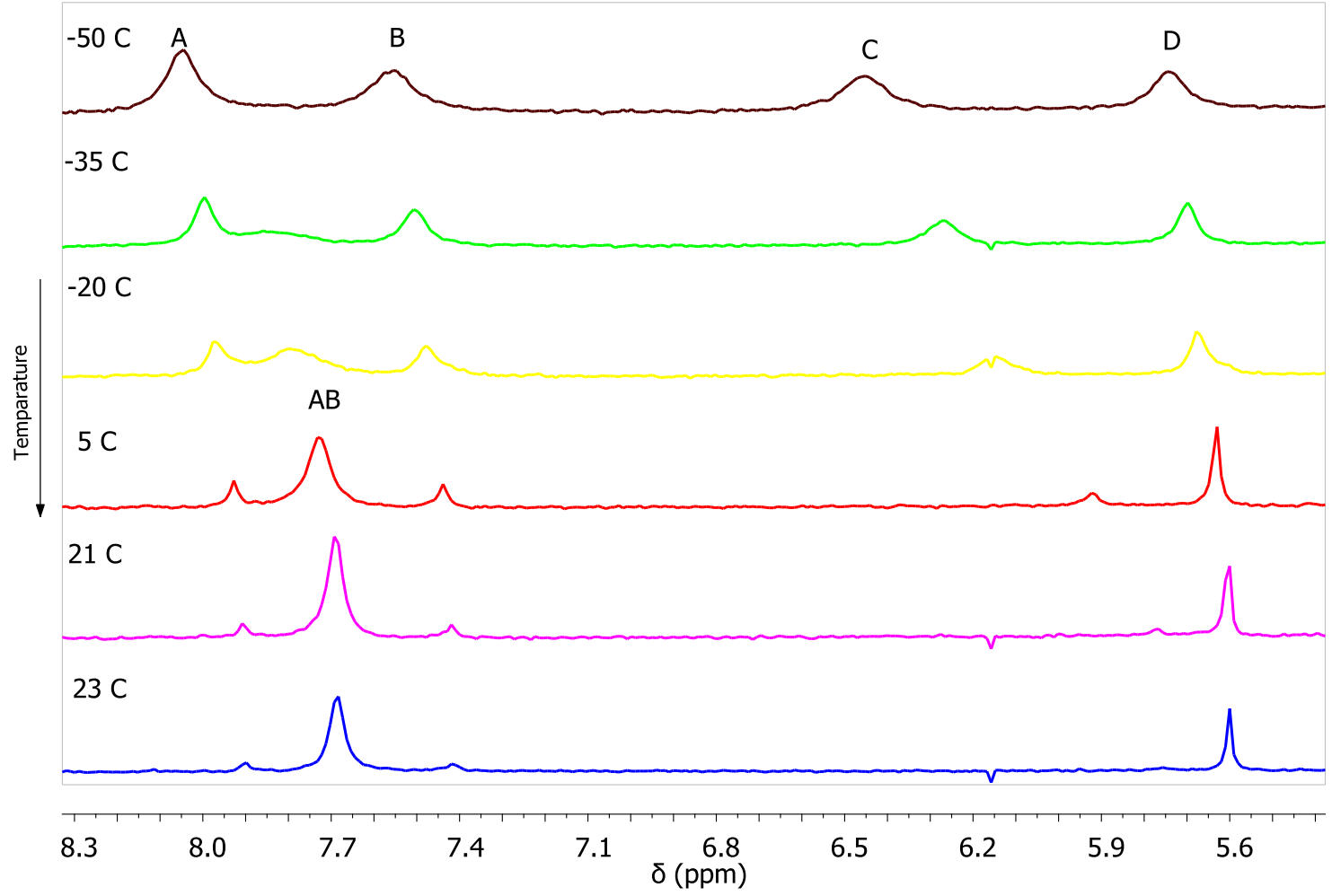

Figure 31. Variable temperature $\left(-50\right.$ to $\left.+23{ }^{\circ} \mathrm{C}\right) 400 \mathrm{MHz}{ }^{1} \mathrm{H}$ NMR of complex 4 in acetone- $\mathrm{d}_{6}$.

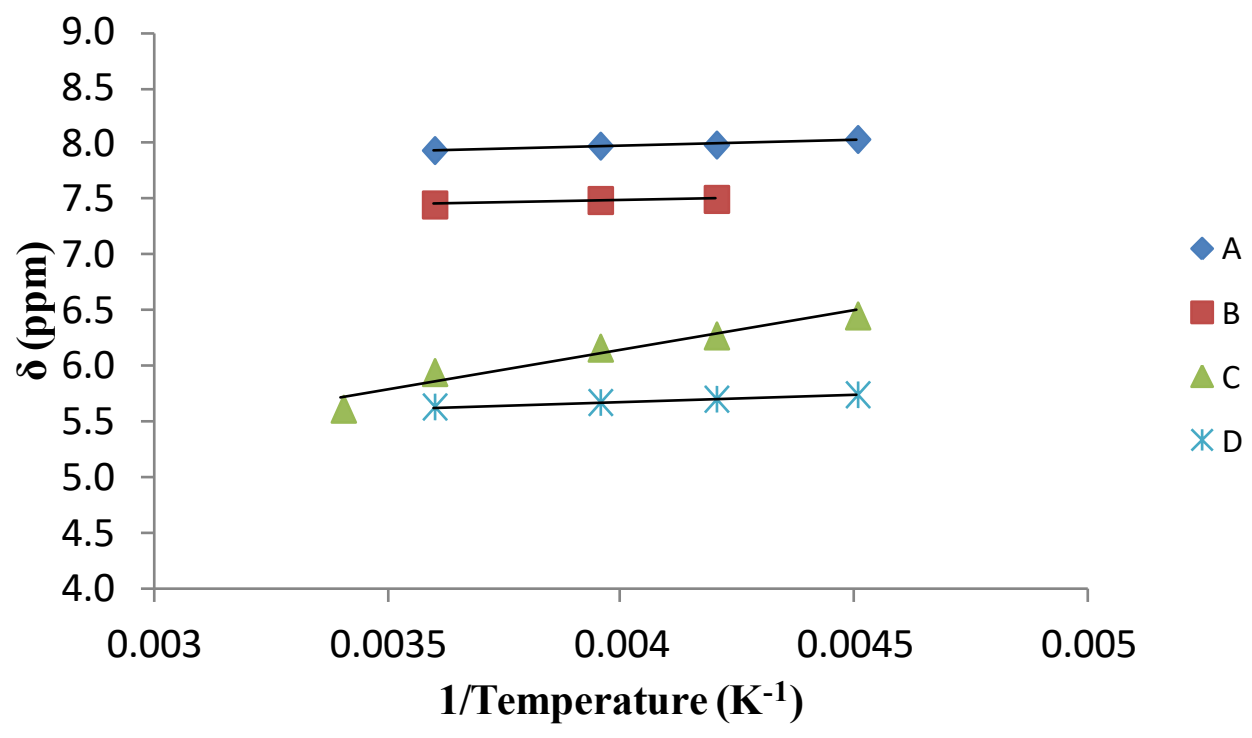

Figure 32. Temperature dependence of $\mathrm{H}$ chemical shifts of complex 4. 
Raising the temperature, for complexes $\mathbf{1}$ and $\mathbf{4}$, caused proton shifts to become coalesced into a single line. At low temperatures the rate of pyrazole tautomerization is low ${ }^{\dagger}$, causing separate signals for protons at position $\mathrm{H}^{3}$ and $\mathrm{H}^{5}$ of the pyrazole to be observed separetely. ${ }^{88}$ The presence of four resonances, instead of eight resonances, in the spectra is consistent of corresponding pyrazole sites: pyrazole trans to a pyrazole and pyrazole trans to a chloride. At room temperature, for both $\mathbf{1}$ and $\mathbf{4}$, peaks around 7.5 ppm and peaks around $6 \mathrm{ppm}$ have 1:2 integration, consistent with the previous assignment. Similar temperature behaviors should be expected for complexes 3, 5 - 6 .

\subsubsection{Electronic paramagnetic resonance of $\mathrm{Cr}^{\mathrm{III}}$ monomers}

The X-band electron paramagnetic resonance (EPR) of chromium(III) monomers with formula $\left[m e r-\mathrm{CrCl}_{3}(4-\mathrm{H}-\mathrm{pzH})_{3}\right]$ (1) and $\left[m e r-\mathrm{CrCl}_{3}(4-\mathrm{Cl}-\mathrm{pzH})_{3}\right]$ (4) were run by collaboration with Joshua Telser (Roosevelt University, Chicago) (Figure 33). The Xband EPR shows broad hyperfine lines typical for a high-spin center from a ground state $\mathrm{S}=3 / 2$ with a small zero-field splitting (ZFS). Simulation of the experimental data will help elucidate EPR parameters like the axial zero-field splitting (D) and the gyromagnetic ratio (g), a distribution in the parameters is expected due to slight structural differences between complexes. ${ }^{89}$

\footnotetext{
${ }^{\dagger}$ Energy barrier is calculated from $\Delta G^{\neq}=4.575 \times 10^{-3} * T *\left(\log \frac{T}{k}+10.318\right)$, where $\mathrm{T}$ is temperature (in $\mathrm{K}$ ), $\mathrm{k}$ is the rate constant (in s $\mathrm{s}^{-1}$ ). Rate constant is defined by $k=2.22 v_{X Y}$, where $v_{\mathrm{AB}}$ is the chemical shift (in Hz) between peaks $\mathrm{X}$ and $\mathrm{Y}$. ( $1 ; \Delta \mathrm{G}_{\mathrm{AB}}^{\neq}=13.9 \mathrm{kcal} / \mathrm{mol}, \Delta \mathrm{G}_{\mathrm{CD}}^{\neq}=14.5 \mathrm{kcal} / \mathrm{mol} ; \mathbf{4}, \Delta \mathrm{G}^{\neq}{ }_{\mathrm{AB}}=14.0$ $\left.\mathrm{kcal} / \mathrm{mol}, \Delta \mathrm{G}_{\mathrm{CD}}^{\ddagger}=13.4 \mathrm{kcal} / \mathrm{mol}\right)$
} 


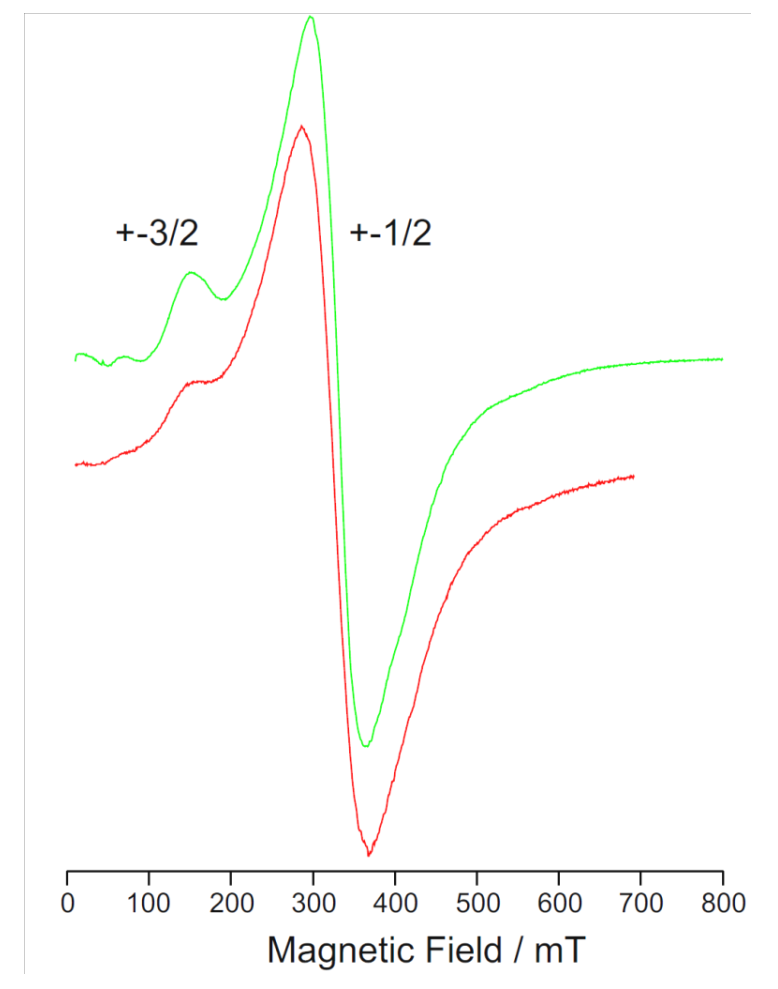

Figure 33. X-Band EPR of $\mathbf{1}$ (red) and $\mathbf{4}$ (green) $(9.376 \mathrm{GHz}), 10 \mathrm{~K}$.

The Q-band EPR spectra of acetonitrile $(\mathrm{MeCN})$ solutions of $\mathbf{1}, \mathbf{3}$, and 4 were recorded in collaboration with Dr. Athanassios K. Boudalis (University of Strasbourg, France). The spectra revealed a derivative main feature around $1220 \mathrm{mT}(g \sim 1.99)$ accompanied by broader and weaker satellite features. These features were attributed to weak zero-field splittings of the single ions, but their broad features could not be reproduced by such a simple model. It was then considered that the system undergoes strain effects, which induce distributions of the effective spin Hamiltonian parameters ( $g$ and/or $D$-strains). Due to the relevance of ZFS in the appearance of the satellite features, only a $D$-strain model was assumed to account for parameter distributions, considering the $g$-tensor components as monodisperse. The $D$ parameter was considered as following a normal distribution. 


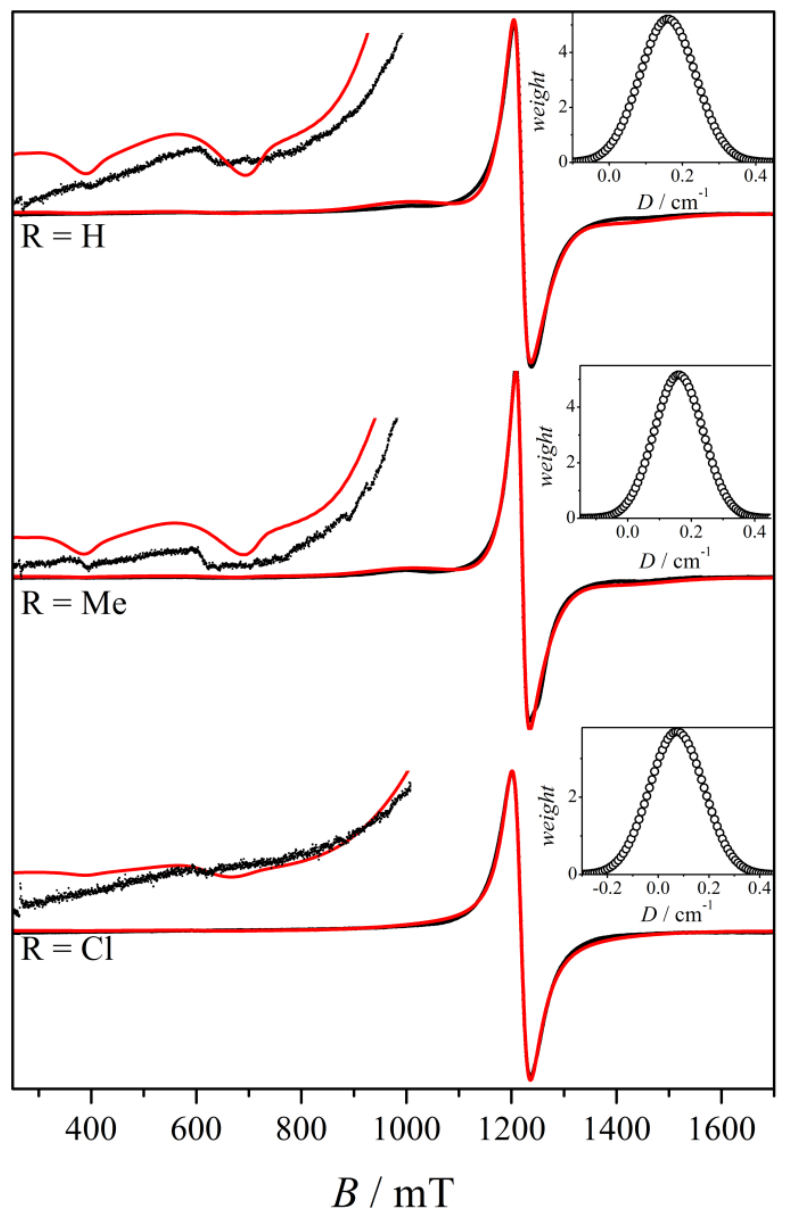

Figure 34. Q-band EPR experimental (black lines) and calculated (red lines) spectra of frozen $\mathrm{MeCN}$ solutions. The insets show the distribution of the $D$ parameter.

Table 10. Best-fit parameters for the Q-band EPR spectra of complexes.

\begin{tabular}{cccccc} 
Compound & $g_{\|}$ & $g_{\perp}$ & $\sigma\left(\mathrm{G}_{\mathrm{pp}}\right)$ & $|D|\left(\mathrm{cm}^{-1}\right)$ & $\sigma D\left(\mathrm{~cm}^{-1}\right)$ \\
\hline $\mathbf{1}$ & 1.99 & 1.99 & 18.1 & 0.16 & 0.18 \\
$\mathbf{3}$ & 1.99 & 1.99 & 15.8 & 0.15 & 0.17 \\
$\mathbf{4}$ & 1.99 & 1.99 & 27.9 & 0.073 & 0.25 \\
\hline
\end{tabular}

[Note: $\sigma$ is the intrinsic linewidth]. 
For this case, the expression for the $g$ factor is defined by:

$$
g=g_{e}-\frac{8 \lambda}{\Delta}
$$

where $\Delta$ is $10 \mathrm{Dq}$ (from Table 9), the energy difference from ${ }^{4} \mathrm{~A}_{2 \mathrm{~g}}$ and ${ }^{4} \mathrm{~T}_{2 \mathrm{~g}}$ levels. ${ }^{90}$ Spinorbit coupling constants $(\lambda)$ are calculated for compound 1, 3, and 4 taking into account that for the $\mathrm{Cr}^{+3}$ free ion $\lambda_{0}=+91 \mathrm{~cm}^{-1}$. The $\pi$-acceptor character of the pyrazole ligands is reflected on the reduction of the spin-orbit constants, where the spin orbit reduction factor $(k)$ is defined by $\lambda=k^{2} \lambda_{0}$. Similar effect had been observed for complexes with imidazole and pyridine ligands. ${ }^{65,91}$

Table 11. Spin-orbit coupling constants $\left(\mathrm{cm}^{-1}\right)$ for $\mathbf{1}, \mathbf{3}$, ad $\mathbf{4}$.

\begin{tabular}{ccccc} 
Compound & $\Delta\left(\mathrm{cm}^{-1}\right)$ & $\lambda\left(\mathrm{cm}^{-1}\right)$ & $\lambda / \lambda_{0}$ & $k$ \\
\hline $\mathbf{1}$ & 16287 & 25.1 & 0.276 & 0.525 \\
$\mathbf{3}$ & 16695 & 25.7 & 0.283 & 0.532 \\
$\mathbf{4}$ & 15674 & 24.1 & 0.265 & 0.515
\end{tabular}

The ZFS parameter $|\mathrm{D}|$ for mononuclear chromium(III) complexes with monodentate ligands typically falls in the range of $0.06-0.1 \mathrm{~cm}^{-1}$ and the corresponding g values at approximately $1.98-1.99$, which is comparable with the obtained $|\mathrm{D}|$ and $g$ values for $4 .^{92,93}$ Increase in $|\mathrm{D}|$ values can be attributed to a larger spin-orbit constant from the ligand in $\mathbf{1}$ and $\mathbf{3}$. 


\subsubsection{Base addition to mononuclear $\mathrm{Cr}^{\mathrm{III}}$ pyrazole complexes}

Higher nuclearity complexes are expected to form from the deprotonation of coordinated pyrazole ligands. Mononuclear complexes with formula $\left[\mathrm{mer}-\mathrm{CrCl}_{3}(\mathrm{pz} * \mathrm{H})_{3}\right]$ were reacted with a variety of bases in organic and inorganic solvents to deprotonate the coordinated pyrazoles and possibly accomplish higher nuclearity complexes. Change in color is observed from green to pink in the reaction of $\left[m e r-\mathrm{CrCl}_{3}(\mathrm{pzH})_{3}\right]$ (1) with triethylamine in acetonitrile. A time-dependant UV-Vis experiment shows two isosbestic points at $427 \mathrm{~nm}$ and $496 \mathrm{~nm}$. A third "isosbestic point" at $583 \mathrm{~nm}$ is blurred, implying the presence of a minor impurity that absorbs close to that wavelength. ${ }^{94}$ Failure to isolate pure product has hampered all attempts of base addition reactions in various solvents and isolation methods.

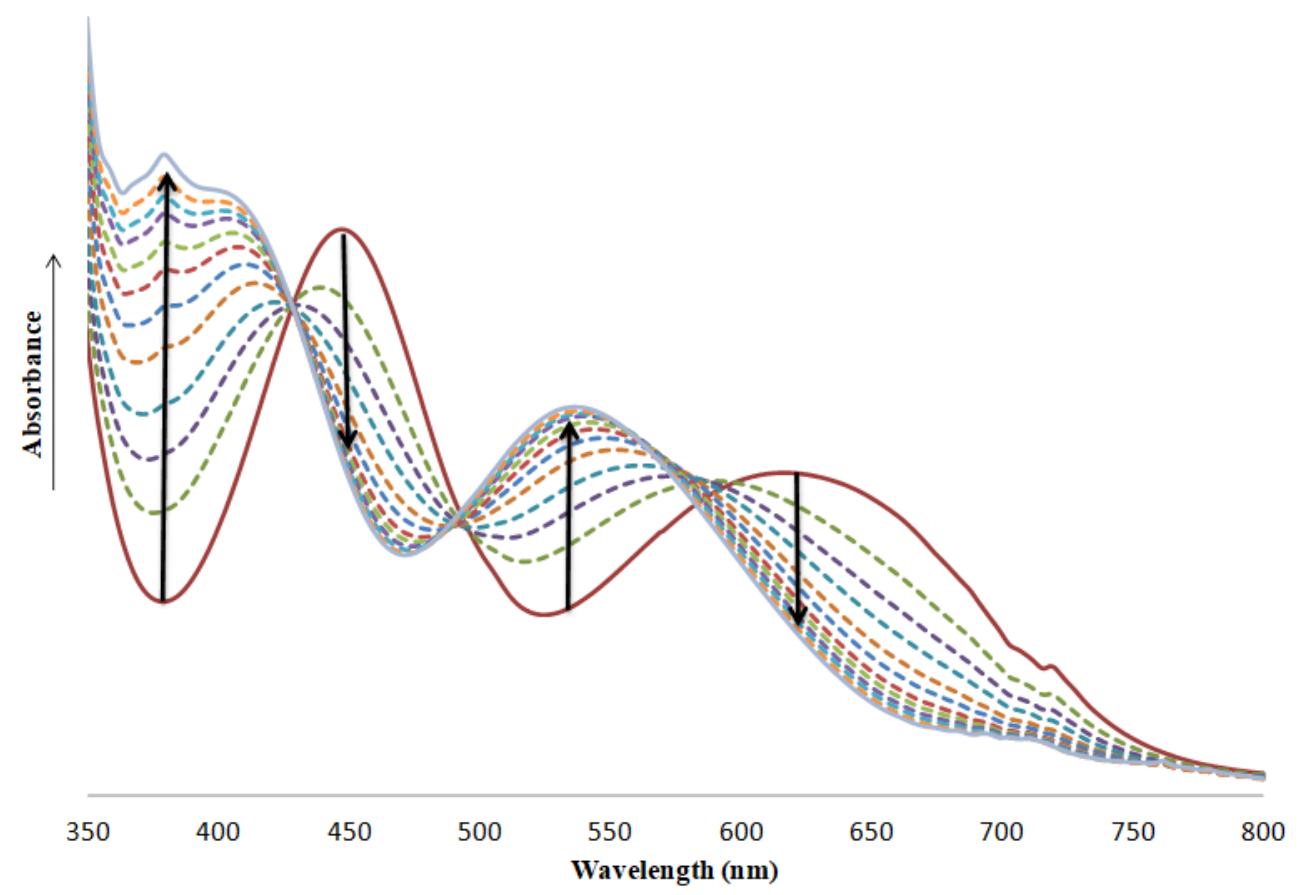

Figure 35. Time-dependant UV-Vis spectra for the reaction of $\left[\right.$ mer- $\left.\mathrm{CrCl}_{3}(\mathrm{pzH})_{3}\right](\mathbf{1})$ with triethylamine in acetonitrile. 


\subsubsection{Other products from mononuclear $\mathrm{Cr}^{\mathrm{III}}$ pyrazole syntheses}

Further study of mononuclear chromium complexes syntheses has provided insight on the difficulty of product isolation from base addition reactions. From the reaction mixture of $\mathrm{CrCl}_{3} \cdot 6 \mathrm{H}_{2} \mathrm{O}$ and 3-Me-pzH in dichloromethane (DCM), where green crystals of $\left[\right.$ mer- $\left.\mathrm{CrCl}_{3}(3-\mathrm{Me}-\mathrm{pzH})_{3}\right]$ (2) and $\left[\right.$ trans $\left.-\mathrm{CrCl}_{3}(3-\mathrm{Me}-\mathrm{pzH})_{3}\right] \mathrm{Cl}$ (8) were isolated, trace amount of $\left[\mathrm{Cr}_{3}^{\mathrm{III}}{ }_{3}\left(\mu_{3}-\mathrm{O}\right)(\mu-\mathrm{OH})_{3}(3-\mathrm{Me}-\mathrm{pzH})_{9}\right] \mathrm{Cl}_{4}(9)$ was also obtained as pink crystals. Bulk synthesis of (9) was not successful from the stoichiometrically optimized reaction. Isolation of analogous material using similar reaction conditions with other pyrazole ligands was then attempted.

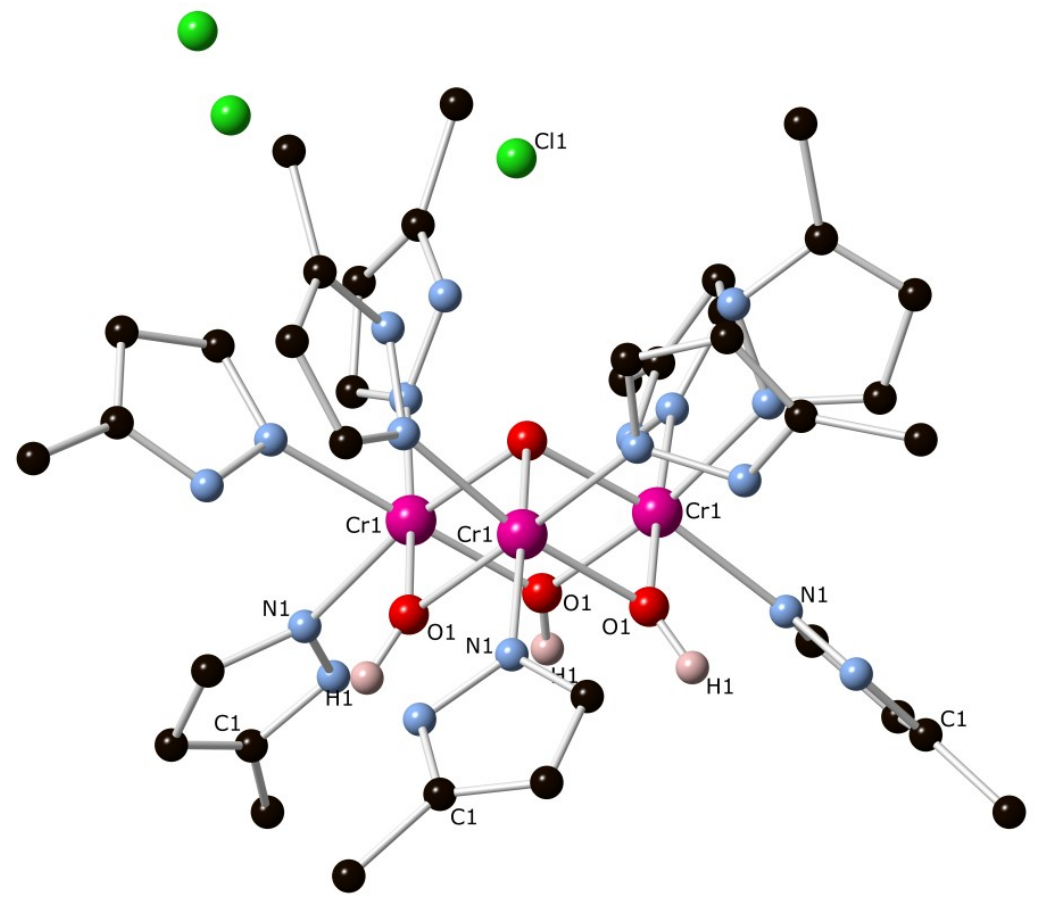

Figure 36. Ball and stick representation of $\left[\mathrm{Cr}_{3}^{\mathrm{III}}\left(\mu_{3}-\mathrm{O}\right)(\mu-\mathrm{OH})_{3}(3-\mathrm{Me}-\mathrm{pzH})_{9}\right] \mathrm{Cl}_{4}(9)$. Some hydrogen atoms are omitted for clarity. 
The use of 4-Me-pyrazole ligand was explored using similar reaction conditions, as complex (9), from which the analogous trinuclear complex with $\left[\mathrm{Cr}_{3}\left(\mu_{3}-\mathrm{O}\right)(\mu-\mathrm{OH})_{3}\right]$ core was not isolated. Instead, green crystals of $\left[\right.$ mer- $\left.\mathrm{Cr}_{3} \mathrm{Cl}_{3}(4-\mathrm{Me}-\mathrm{pzH})_{3}\right]$ (3) were obtained. Additionally, purple crystals of dinuclear complex with formula $\left[\mathrm{Cr}_{2}^{\mathrm{III}}{ }_{2}(\mu-\right.$ $\left.\mathrm{OH})(\mu-4-\mathrm{Me}-\mathrm{pz})(4-\mathrm{Me}-\mathrm{pzH})_{4} \mathrm{Cl}_{4}\right](\mathbf{1 0})$ and pink crystals of $\left[\mathrm{Cr}^{\mathrm{III}}(\mu-\mathrm{OH})(\mu-4-\mathrm{Me}-\mathrm{pz})_{2}(4-\right.$ Me-pzH) $\left.{ }_{4} \mathrm{Cl}_{2}\right] \mathrm{Cl}(\mathbf{1 1})$ were obtained in a very low yield.

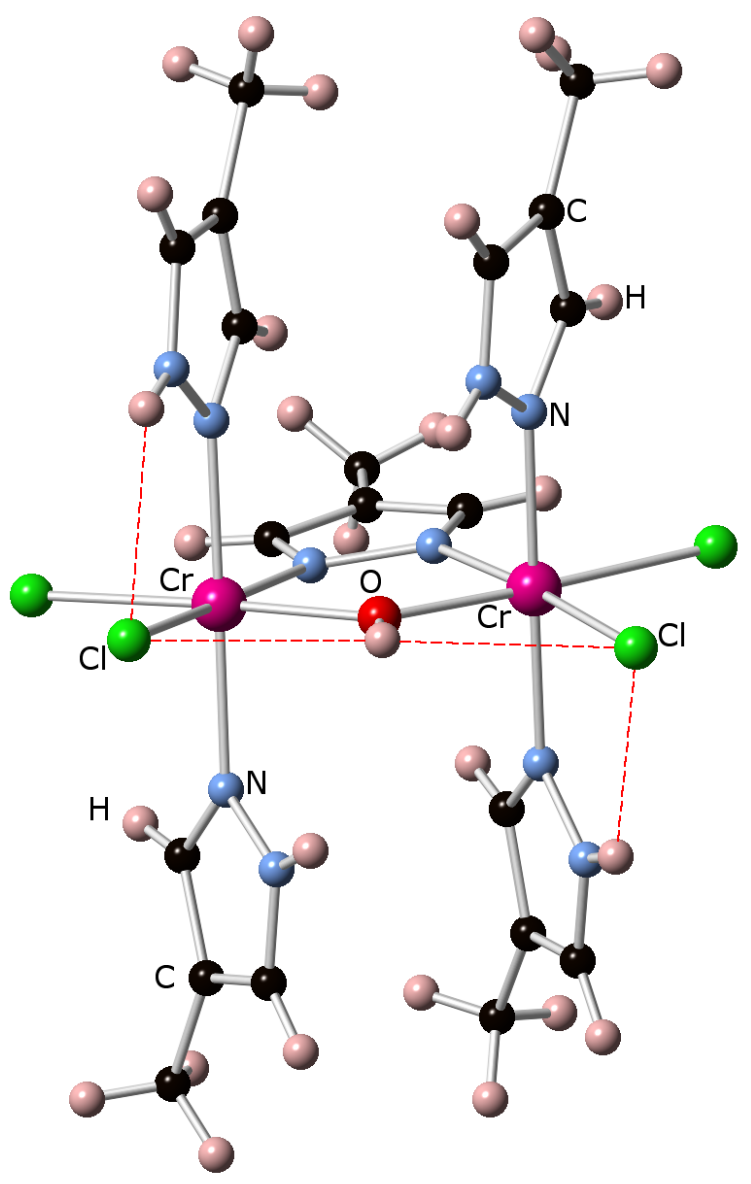

Figure 37. Ball and stick representation of $\left[\mathrm{Cr}^{\mathrm{III}}{ }_{2}(\mu-\mathrm{OH})(\mu-4-\mathrm{Me}-\mathrm{pz})(4-\mathrm{Me}-\mathrm{pzH})_{4} \mathrm{Cl}_{4}\right]$ (10) Dashed red lines represent H-bonds. 


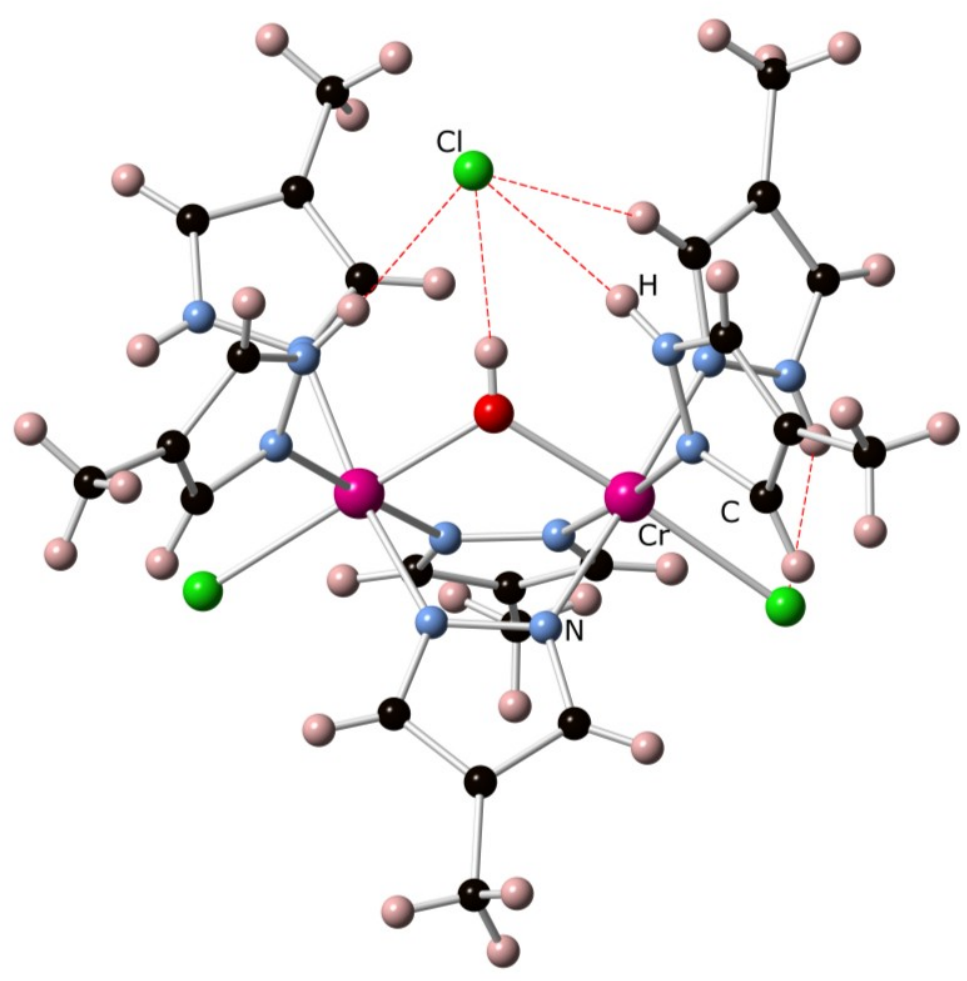

Figure 38. Ball and stick representation of $\left[\mathrm{Cr}^{\mathrm{III}}{ }_{2}(\mu-\mathrm{OH})(\mu-4-\mathrm{Me}-\mathrm{pz})_{2}(4-\mathrm{Me}-\mathrm{pzH})_{4} \mathrm{Cl}_{2}\right] \mathrm{Cl}$ (11). Dashed red lines represent H-bonds.

To address the problem of low yields for the aforementioned dinuclear complexes syntheses, anhydrous $\mathrm{CrCl}_{2}$ and 4-R-pyrazole $(\mathrm{R}=\mathrm{Me}, \mathrm{H}, \mathrm{Cl})$ were reacted in $\mathrm{DCM}$. Reactions yielded mononuclear complex of form $\left[\right.$ mer $\left.-\mathrm{Cr}_{3} \mathrm{Cl}_{3}(4-\mathrm{R}-\mathrm{pzH})_{3}\right]$ as the major product and traces of dinuclear complex with general formula $\left[\mathrm{Cr}^{\mathrm{III}}{ }_{2}(\mu-\mathrm{OH})(\mu-4-\mathrm{R}-\right.$ $\left.\mathrm{pz})_{2}(4-\mathrm{R}-\mathrm{pzH})_{4} \mathrm{Cl}_{2}\right] \mathrm{Cl}, \mathrm{R}=\mathrm{Me}(\mathbf{1 1}), \mathrm{H}(\mathbf{1 2})$ and $\mathrm{Cl}(\mathbf{1 3})$. 


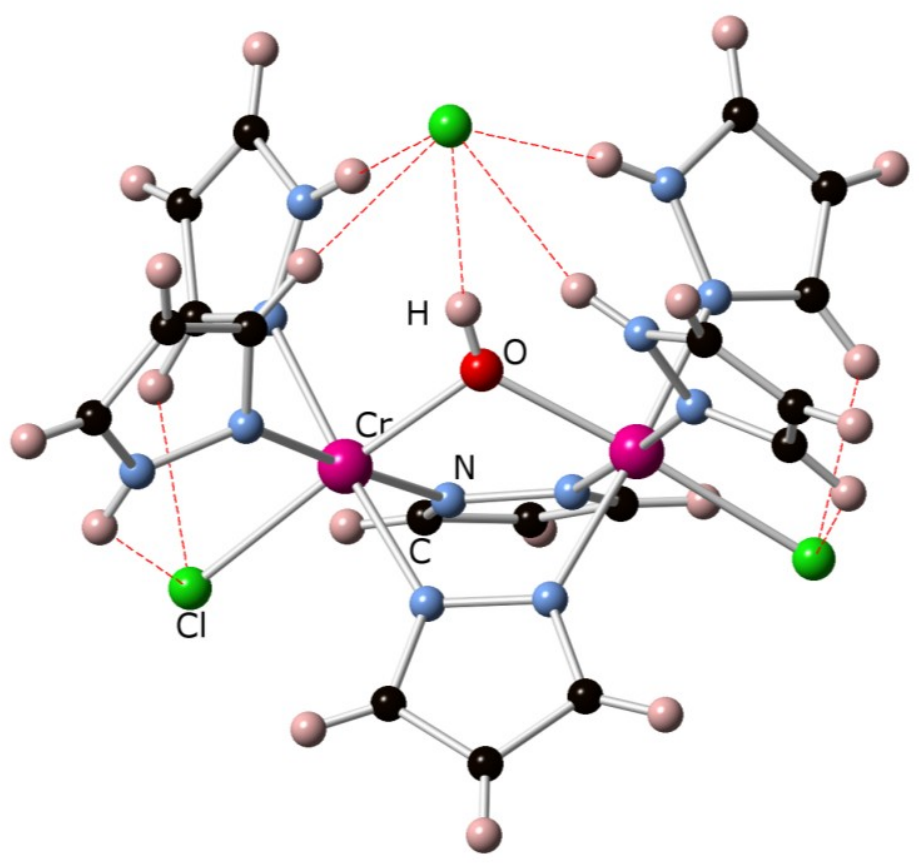

Figure 39. Ball and stick representation of $\left[\mathrm{Cr}^{\mathrm{III}}(\mu-\mathrm{OH})(\mu-\mathrm{pz})_{2}(\mathrm{pzH})_{4} \mathrm{Cl}_{2}\right] \mathrm{Cl}(\mathbf{1 2})$. Dashed red lines represent $\mathrm{H}$-bonds.

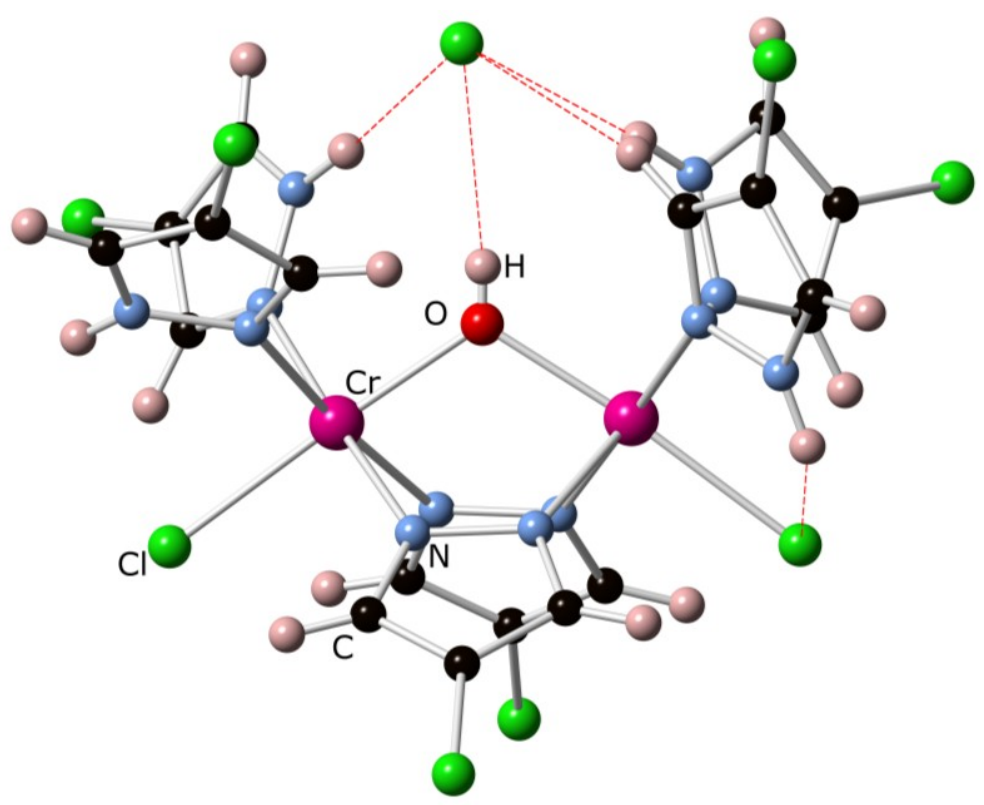

Figure 40. Ball and stick representation of $\left[\mathrm{Cr}^{\mathrm{III}}{ }_{2}(\mu-\mathrm{OH})(\mu-4-\mathrm{Cl}-\mathrm{pz})_{2}(4-\mathrm{Cl}-\mathrm{pzH})_{4} \mathrm{Cl}_{2}\right] \mathrm{Cl}$ (13). Dashed red lines represent H-bonds. 
The described trinuclear and dinuclear pyrazolate complexes can be synthesized from the same reaction mixture from which the mononuclear complexes with mer-and trans- configuration were obtained. Metal coordination shows an increase in pyrazole acidity, since no base addition yielded dinuclear pyrazolate complexes. In all cases, efforts to improve the yield of dinuclear and trinuclear species were unsuccessful, due to the formation of stable mer- complexes. Equilibrium between mononuclear, dinuclear, and trinuclear complexes in solution is the source of complexity in isolating polynuclear products after the addition of base to complexes of mer- configuration.

Analogous dinuclear chromium acetate complexes with $\left[\mathrm{Cr}_{2}(\mu-\mathrm{OH})(\mu-\right.$ $\left.\left.\mathrm{O}_{2} \mathrm{CR}\right)_{2}(\mathrm{~L})_{6}\right]^{3+}$ motif have been shown to be intermediates of formation of oxo-centered trinuclear complexes with form $\left[\mathrm{Cr}_{3}\left(\mu_{3}-\mathrm{O}\right)\left(\mu-\mathrm{O}_{2} \mathrm{CR}\right)_{6}(\mathrm{~L})_{3}\right]^{+}{ }^{+5-97}$ Following that most trinuclear chromium acetate complexes are achieved by thermal treatment routes; the trinuclear motif with formula $\left[\mathrm{Cr}_{3}^{\mathrm{III}}\left(\mu_{3}-\mathrm{O}\right)\left(\mu-\mathrm{pz}^{*}\right)_{6} \mathrm{~L}_{3}\right]$ should be achievable with the use of high temperatures following the addition of base. To prevent the formation of mercomplexes, chromium source without chloride was considered.

\subsubsection{Crystallographic description of trinuclear and dinuclear complexes}

Crystallographic data collection and refinement parameters for 9-13 are summarized in Table 16. Complex 9 crystallized in cubic $P a-3$ space group with one third of the molecule per asymmetric unit and 4/3 $\mathrm{Cl}^{-}$counter ions. Complex 10 crystallized in trigonal $P-3 c 1$ space group with one half molecule per asymmetric unit. Complexes 11, 12, and 13 are isostructural and crystallized in the $P 2_{1} / c$ space group with a whole molecule per asymmetric unit. 
Complex 9 has three 6-coordinate octahedral $\mathrm{Cr}^{\mathrm{III}}$ centers contained on a plane with $\mathrm{Cr} \cdots \mathrm{Cr}$ distance $2.952(2) \AA$ and also coordinated to three 4-Me-pzH ligands. Bridging $\mu_{3}-\mathrm{O}$ and one $\mathrm{Cl}^{-}$counter ion are located on a 3-fold rotation axis, $\mathrm{Cr}-\mathrm{O}_{\mu}$ bond length 1.965(4) $\AA$. Adjacent chromium centers are bridged by $\mu-\mathrm{OH}$, with $\mathrm{Cr}-\mathrm{O}_{\mu}$ bond length of 1.945(4) Å. Complex 9 crystallized with four chloride counter ions showing hydrogen bonding with pyrazole ligands.

Complex 10 contains two 6-coordinate octahedral $\mathrm{Cr}^{\mathrm{III}}$ centers bridged by a $\mu-\mathrm{OH}$ and a $\mu-4-\mathrm{Me}-\mathrm{pz}$. Each chromium center is also coordinated to two 4-Me-pzH ligands and two chloride atoms. In contrast, complexes 11, 12, and 13 contain two bridging pyrazolate ligands and one terminally coordinated chloride per $\mathrm{Cr}$ center. Complex $\mathbf{1 0}$ is neutral, while 11, 12, and 13 co-crystallized with a chloride counter anion. Selected bond distances are listed in Table 12. There is a considerable metal-to-metal distance reduction upon the increase number of bridging pyrazolate ligand. No obvious difference in $\mathrm{Cr} \cdots \mathrm{Cr}$ distance is observed within dinuclear complexes with 4-Me-pzH and 4-H-pzH, in contrast to the elongated $\mathrm{Cr} \cdots \mathrm{Cr}$ distance of the 4-Cl-pzH complex. Analogous dinuclear complexes are known with carboxylate ligands, bond lengths and angles are summarized in Table 13. Pyrazolate complexes have a reduced $\mathrm{Cr} \cdots \mathrm{Cr}$ distances and $\mathrm{Cr}-\mathrm{OH}-\mathrm{Cr}$ angles, associated with their higher rigidity and reduced bite angle of the pyrazolate compared to the carboxylate ligand. However, the $\mathrm{Cr} \cdots \mathrm{Cr}$ distances of 11, 12 and 13 are still too long for metal-metal bonding. 
Table 12. Selected bond lengths $(\AA)$ and angles $\left(^{\circ}\right)$ for dinuclear chromium pyrazolate complexes.

\begin{tabular}{ccccc} 
& \multicolumn{4}{c}{ Compound } \\
\cline { 2 - 5 } Bond & $\mathbf{1 0}$ & $\mathbf{1 1}$ & $\mathbf{1 2}$ & $\mathbf{1 3}$ \\
\hline $\mathrm{Cr} \cdots \mathrm{Cr}$ & $3.4685(4)$ & $3.2482(2)$ & $3.2402(2)$ & $3.2649(5)$ \\
$\mathrm{Cr}-\mathrm{Cl}$ & $2.2993(2)$ & $2.3216(1)$ & $2.3113(1)$ & $2.3026(4)$ \\
& & $2.3079(2)$ & $2.3159(1)$ & $2.3250(3)$ \\
$\mathrm{Cr}-\mathrm{N}(\mu)$ & $2.0123(1)$ & $2.0208(1)-2.0261(1)$ & $2.0190(1)-2.0831(1)$ & $2.0250(3)-2.386(2)$ \\
$\mathrm{Cr}-\mathrm{N}$ & $2.0759(2)$ & $2.0671(2)-2.0869(1)$ & $2.0735(1)-2.0881(2)$ & $2.0754(3)-2.1053(2)$ \\
& $2.0573(2)$ & & & \\
$\mathrm{Cr}-\mathrm{O}$ & $1.9554(2)$ & $1.9406(1)-1.9495(1)$ & $1.9462(1)$ & $1.9472(2)$ \\
& & & $1.9417(1)$ & $1.9532(3)$ \\
$\mathrm{Cr}-\mathrm{OH}-\mathrm{Cr}$ & $124.977(5)$ & $113.228(4)$ & $112.902(2)$ & $113.66(1)$
\end{tabular}

Table 13. Bond lengths $(\AA)$ and angles $\left(^{\circ}\right)$ for selected $\mathrm{Cr}^{\mathrm{III}}$ carboxylate complexes

\begin{tabular}{lccc} 
& \multicolumn{2}{c}{ Bond length $(\AA)$} & Angle ( $\left.{ }^{\circ}\right)$ \\
\cline { 2 - 4 } Complex & $\mathbf{C r} \cdots \mathbf{C r}$ & $\mathbf{C r}-\boldsymbol{\mu O}$ & $\mathbf{C r}-\mathbf{O H}-\mathbf{C r}$ \\
\hline$\left[\mathrm{Cr}_{2}(\operatorname{tren})_{2}(\mu-\mathrm{OH})\left(\mu-\mathrm{O}_{3} \mathrm{C}\right)\right]\left(\mathrm{ClO}_{4}\right)_{3}{ }^{98}$ & 3.560 & $1.944(2)$ & $131.5(3)$ \\
{$\left[\mathrm{Cr}_{2}\left(\mathrm{OH}_{2}\right)_{8}(\mu-\mathrm{OH})\left(\mu-\mathrm{O}_{2} \mathrm{CCH}_{3}\right)\right]\left(\left(\mathrm{CH}_{3}\right)_{3} \mathrm{C}_{6} \mathrm{H}_{2} \mathrm{SO}_{3}\right)_{4}{ }^{97}$} & $3.55(1)$ & $1.92(1)$ & $133.1(7)$ \\
$\left.\left[\mathrm{Cr}_{2}\left(\mathrm{OH}_{2}\right)_{6}(\mu-\mathrm{OH})\left(\mu-\mathrm{O}_{2} \mathrm{CH}\right)_{2}\right]\left(\mathrm{p}-\mathrm{CH}_{3}\right)_{3} \mathrm{C}_{6} \mathrm{H}_{2} \mathrm{SO}_{3}\right)_{4}{ }^{96}$ & $3.381(1)$ & $1.920(4)$ & $123.4(2)$
\end{tabular}

\subsection{Conclusions}

Complexes with formula $\left[m e r-\mathrm{CrCl}_{3}\left(\mathrm{pz}^{*} \mathrm{H}\right)_{3}\right](\mathrm{pzH}=$ pyrazole ligand; $\mathrm{pz} * \mathrm{H}=3-$ Me-pzH, 4-Me-pzH, 4-Cl-pzH, 4-Br-pzH, 4-I-pzH) and [trans- $\left.\mathrm{CrCl}_{2}\left(\mathrm{pz}^{*} \mathrm{H}\right)_{4}\right] \mathrm{Cl}\left(\mathrm{pz}^{*} \mathrm{H}=\right.$ pzH, 3-Me-pzH) were synthesized and characterized. Complexes are both NMR and EPR active. Variable temperature NMR elucidated that fewer number of resonance peaks is caused by tautomerism in solution. The EPR data show broad hyperfine lines typical for a high-spin chromium center. The ZFS parameter $|\mathrm{D}|$ for mononuclear chromium(III) complexes 1, 3 and 4 was determined and falls within range compared to other chromium(III) complexes with monodentate ligands Increase in $|\mathrm{D}|$ values are attributed to a larger spin-orbit constant from the ligand in $\mathbf{1}$ and $\mathbf{3}$. Polynuclear complexes were not 
isolated from base addition to mononuclear chromium complexes. Trinuclear complex with formula $\left[\mathrm{Cr}_{3}^{\mathrm{III}}\left(\mu_{3}-\mathrm{O}\right)(\mu-\mathrm{OH})_{3}(3-\mathrm{Me}-\mathrm{pzH})_{9}\right] \mathrm{Cl}_{4}$, dinuclear complexes with formula $\left[\mathrm{Cr}^{\mathrm{III}}{ }_{2}(\mu-\mathrm{OH})(\mu-4-\mathrm{Me}-\mathrm{pz})(4-\mathrm{Me}-\mathrm{pz})_{4} \mathrm{Cl}_{4}\right]$ and $\left[\mathrm{Cr}^{\mathrm{III}}{ }_{2}(\mu-\mathrm{OH})(\mu-4-\mathrm{R}-\mathrm{pz})_{2}(4-\mathrm{R}-\mathrm{pz})_{4} \mathrm{Cl}_{2}\right] \mathrm{Cl}(\mathrm{R}$ $=\mathrm{Me}, \mathrm{H}$ and, $\mathrm{Cl}$ ) were isolated as side products of mononuclear complex syntheses. Equilibrium of mentioned complexes in solution with the mononuclear complexes might have prevented the isolation of pure polynuclear complexes from their reaction with base. The use of chromium sources without chloride and thermally assisted synthesis may improve the yields of the aforementioned trinuclear and dinuclear complexes. Analysis of magnetic data from complexes with formula $\left[\mathrm{Cr}_{3} \mathrm{III}_{3}\left(\mu_{3}-\mathrm{O}\right)(\mu-\mathrm{OH})_{3}(\mathrm{pzH})_{9}\right]^{+4}$ could elucidate the existence of a metal-to-metal bond. As previously mentioned, $\mathrm{Cr}-\mathrm{Cr}$ bonds range between $1.74-2.69 \AA$, which make this complex the top limit of its kind, given that the observed $\mathrm{Cr} \cdots \mathrm{Cr}$ distance was 2.952(2) $\AA$.

\subsection{Experimental section}

\subsubsection{Materials}

Reagent grade chemicals were purchased from Fisher scientific, Aldrich Chemical Co, Alfa Aesar or ACROS Organics. Reactions were performed at room temperature. Elemental analyses of crystalline material were performed by Galbraith Laboratories, Knoxville, TN.

\subsubsection{Instrumentation}

Electrochemical experiments were performed with a BAS CV $50 \mathrm{~W}$ voltammetric analyzer in $0.1 \mathrm{M} \mathrm{Bu}_{4} \mathrm{NPF}_{6} / \mathrm{CH}_{2} \mathrm{Cl}_{2}$ using a non-aqueous $\mathrm{Ag} / \mathrm{AgNO}_{3}$ reference electrode for which the ferricenium/ferrocene couple occurs at $0.200 \mathrm{~V}$, glassy carbon auxiliary 
electrode, and glassy carbon working electrode. ${ }^{1} \mathrm{H}$ NMR spectra were recorded on a 400 Bruker NMR spectrometer and were referenced, using the residual solvent resonances. FT-IR and UV-Vis spectra were recorded at room temperature with a Perkin Elmer Spectrum 100 FT-IR S and a Varian Cary 3000 spectrometer, respectively.

\subsubsection{Synthesis and characterization}

\subsubsection{Synthesis of $\left[m e r-\mathrm{CrCl}_{3}(\mathrm{pzH})_{3}\right](1)$.}

Method A: A $25 \mathrm{~mL}$ flask was charged with $124.4 \mathrm{mg}(0.466 \mathrm{mmol})$ of $\mathrm{CrCl}_{3} \cdot 6 \mathrm{H}_{2} \mathrm{O}$ and dissolved with $15 \mathrm{~mL}$ of THF followed by addition of $159.9 \mathrm{mg}(2.35 \mathrm{mmol})$ of pyrazole (pzH). The solution was left stirring for 24 hours. Dark green crystals of (1) were obtained from slow evaporation of solvent; crystal yield, $107 \mathrm{mg}$ (66 \%). Elemental analysis calculated for $\mathrm{C}_{9} \mathrm{H}_{12} \mathrm{Cl}_{3} \mathrm{CrN}_{6}$ : C, 29.81;

H, 3.34; N, 23.18. Found: C, 29.46; H, 3.35; N, 22.98. FTIR ( $\mathrm{cm}^{-1}$,solid): 669 m, 712 s, 765 s, 868 w, 908 w, 944 w, 1046 s, 1118 s, 1160 w, 1261 w, 1345 m, $1401 \mathrm{w}, 1470 \mathrm{~m}, 1514 \mathrm{w}, 3143 \mathrm{w}, 3307 \mathrm{~m}, 3354 \mathrm{w}$. UV-Vis (MeOH) $\lambda_{\max }$ (ع); $\mathrm{nm}\left(\mathrm{M}^{-1} \mathrm{~cm}^{-1}\right): 448$ (62.0), 614 (37.0). ${ }^{1} \mathrm{H}$ NMR (400 MHz, $\left.\mathrm{CD}_{3} \mathrm{CN}\right) \delta$ $7.70(1), 6.30(0.5),-9.00(11)$.

Method B: $153 \mathrm{mg}(1.25 \mathrm{mmol})$ of $\mathrm{CrCl}_{2}$ were suspended in $10 \mathrm{~mL}$ of DCM, followed by the addition of $345.5 \mathrm{mg}(5.07 \mathrm{mmol})$ of pyrazole. Green crystals of (1) are isolated from diethyl ether vapor diffusion into a DCM solution. Pink crystals of $\left[\mathrm{Cr}^{\mathrm{III}}{ }_{2}(\mu-\mathrm{OH})(\mu-\mathrm{pz})_{2}(\mathrm{pzH})_{4} \mathrm{Cl}_{2}\right] \mathrm{Cl}$ (12) were isolated from evaporation of diethyl ether/DCM solution. 


\subsubsection{Synthesis of $\left[m e r-\mathrm{CrCl}_{3}(3-\mathrm{Me}-\mathrm{pzH})_{3}\right](2)$.}

Method A: A $25 \mathrm{~mL}$ flask was charged with $106.0 \mathrm{mg}(0.86 \mathrm{mmol})$ of $\mathrm{CrCl}_{2}$ and dissolved with $10 \mathrm{~mL}$ of methanol at room temperature. Translucent green solution was obtained to which $220.0 \mu \mathrm{L}(2.60 \mathrm{mmol})$ of 3-Methyl-pyrazole (3-Me-pzH) were added drop-wise and left stirring for 24 hours. Product was isolated from reduced pressure vaporization of solvent. Dark green single crystals of (2) were obtained from hexane solvent layering in a DCM solution. Elemental analysis calculated for $\mathrm{C}_{12} \mathrm{H}_{18} \mathrm{Cl}_{3} \mathrm{CrN}_{6}$ : $\mathrm{C}, 35.62 ; \mathrm{H}, 4.48$; N, 20.77. Found: C, 35.31; H, 4.88; N, 20.08. FTIR ( $\mathrm{cm}^{-1}$, solid): 675 vs, 791 vs, $808 \mathrm{~s}, 956 \mathrm{~s}, 1016 \mathrm{w}, 1105 \mathrm{vs}, 1283 \mathrm{w}, 1411 \mathrm{w}, 1444 \mathrm{w}, 1487 \mathrm{w}, 1559 \mathrm{~m}$, $3135 \mathrm{vw}, 3312 \mathrm{~m}$. UV-Vis $(\mathrm{MeOH}) \lambda_{\max }(\varepsilon) ; \mathrm{nm}\left(\mathrm{M}^{-1} \mathrm{~cm}^{-1}\right): 446$ (41.4), 608 (38.6).

After removal of green crystals from the reaction mixture of (2), trace mount of pink single crystals of $\left[\right.$ trans- $\left.\mathrm{CrCl}_{2}(3-\mathrm{Me}-\mathrm{pzH})_{4}\right] \mathrm{Cl}(\mathbf{8})$ were obtained from evaporation of a 1:1 dichloromethane/hexane mixture.

Method B: A $25 \mathrm{~mL}$ flask was charged with $299.7 \mathrm{mg}(1.12 \mathrm{mmol})$ of $\mathrm{CrCl}_{3} \cdot 6 \mathrm{H}_{2} \mathrm{O}$, followed by addition of $10 \mathrm{~mL}$ of DCM. To the resulting suspension, 360 $\mu \mathrm{L}(4.42 \mathrm{mmol})$ of 3-Me-pzH was added. Green crystals of (2) were obtained from slow evaporation of solvent after filtration. Trace amounts of $\left[\mathrm{Cr}_{3}{ }_{3}{ }_{3}\left(\mu_{3}-\mathrm{O}\right)(\mu-\mathrm{OH})_{3}(3-\mathrm{Me}-\mathrm{pzH})_{9}\right] \mathrm{Cl}_{4}$ (9), were also collected as blue crystals. 


\subsubsection{Synthesis of $\left[m e r-\mathrm{CrCl}_{3}(4-\mathrm{Me}-\mathrm{pzH})_{3}\right](3)$.}

Method A: A translucent green solution was obtained from dissolving $118.7 \mathrm{mg}(0.445$ mmol) of $\mathrm{CrCl}_{3} \cdot 6 \mathrm{H}_{2} \mathrm{O}$ in $15 \mathrm{~mL}$ of THF. A $2 \mathrm{~mL}$ solution of $189 \mu \mathrm{g}(2.233$ mmol) of 4-Methyl-pyrazole (4-Me-pzH) in THF was then added drop wise. Green single crystals of (3) were obtained from slow evaporation of solvent; crystal yield $54 \mathrm{mg}(30 \%)$. Elemental analysis calculated for $\mathrm{C}_{12} \mathrm{H}_{18} \mathrm{Cl}_{3} \mathrm{CrN}_{6}$ : C, 35.62; H, 4.48; N, 20.77. Found: C, 35.68; H, 4.43; N, 20.53. FTIR $\left(\mathrm{cm}^{-1}\right.$, solid): 658 w, 693 m, 744 w, 966 m, 1001 s, 1071 s, 1118 s, 1237 w, 1292 w, $1334 \mathrm{w}, 1390 \mathrm{w}, 1477 \mathrm{~m}, 1692 \mathrm{w}, 2931 \mathrm{w}, 3120 \mathrm{w}, 3280 \mathrm{~s}, 3305$ w. UV-Vis $(\mathrm{MeOH}) \lambda_{\max }(\varepsilon) ; \mathrm{nm}\left(\mathrm{M}^{-1} \mathrm{~cm}^{-1}\right): 439$ (55.0), 599 (43.0). ${ }^{1} \mathrm{H}$ NMR (400 MHz, $\left.\mathrm{CD}_{3} \mathrm{CN}\right) \delta 7.41(0.5), 5.44(1), 2.97(17)$.

Method B: A round bottom flask was charged with $109.7 \mathrm{mg}(0.411 \mathrm{mmol})$ of $\mathrm{CrCl}_{3} \cdot 6 \mathrm{H}_{2} \mathrm{O}$ followed by $5 \mathrm{~mL}$ of DCM. To the suspension, $104.8 \mu \mathrm{L}(1.287$ mmol) of 4-Me-pzH was added, followed by reflux for 4 hours. After evaporation of solvent, green crystals of (3) were obtained from DCM/ ether vapor diffusion. Green crystals and pink solution were observed from the crystallization set up. Traces of purple crystals of $\left[\mathrm{Cr}^{\mathrm{III}}{ }_{2}(\mu-\mathrm{OH})(\mu-4-\mathrm{Me}-\right.$ pz)(4-Me-pzH $\left.)_{4} \mathrm{Cl}_{4}\right](\mathbf{1 0})$ and pink crystals of $\left[\mathrm{Cr}^{\mathrm{III}}{ }_{2}(\mu-\mathrm{OH})(\mu-4-\mathrm{Me}-\mathrm{pz})_{2}(4-\right.$ Me-pzH $\left.)_{4} \mathrm{Cl}_{2}\right] \mathrm{Cl}(\mathbf{1 1})$ were collected from slow evaporation of pink solution. 


\subsubsection{Synthesis if $\left[\right.$ mer- $\left.\mathrm{CrCl}_{3}(4-\mathrm{Cl}-\mathrm{pzH})_{3}\right](4)$.}

Method A: A $25 \mathrm{~mL}$ flask was charged with $50.6 \mathrm{mg}(0.190 \mathrm{mmol})$ of $\mathrm{CrCl}_{3} \cdot 6 \mathrm{H}_{2} \mathrm{O}$ and dissolved with $15 \mathrm{~mL}$ of THF. To the obtained green solution, $99.7 \mathrm{mg}(0.97$ mmol) of 4-Chloro-pyrazole (4-Cl-pzH) was added and left to stir for 24 hours. Solvent was removed under reduced pressure and dark green single crystals of (4) were obtained from diethyl ether vapor diffusion in DCM solution; crystal yield $162 \mathrm{mg}(69 \%)$. Elemental analysis calculated for $\mathrm{C}_{9} \mathrm{H}_{9} \mathrm{Cl}_{6} \mathrm{CrN}_{6}: \mathrm{C}, 23.20 ; \mathrm{H}, 1.95 ; \mathrm{N}, 18.04$. Found: $\mathrm{C}, 23.18 ; \mathrm{H}, 2.12 ; \mathrm{N}$, 17.15. FTIR ( $\mathrm{cm}^{-1}$, solid): 679 vs, $847 \mathrm{~s}, 964$ vs, 1050 vs, 1113 vs, $1203 \mathrm{~m}$, 1259 m, 1339 m, 1391 m, 1463 m, 1530 m, 1691 w, 3124 w, 3263 m, 3331 w. UV-Vis $(\mathrm{MeOH}) \lambda_{\max }(\varepsilon) ; \mathrm{nm}\left(\mathrm{M}^{-1} \mathrm{~cm}^{-1}\right): 448$ (65.0), 618 (30.0). ${ }^{1} \mathrm{H}$ NMR (400 MHz, $\left.\mathrm{CD}_{3} \mathrm{CN}\right) \delta 7.58(1), 5.43(0.4)$.

Method B: A $25 \mathrm{~mL}$ flask was charged with $122 \mathrm{mg}(1.00 \mathrm{mmol})$ of $\mathrm{CrCl}_{2}$ followed by $10 \mathrm{~mL}$ of DCM. To the resulting suspension, $254.8 \mathrm{mg}(2.50 \mathrm{mmol})$ of $4-\mathrm{Cl}-$ pzH was added. Green crystals and pink solution were obtained after diffusing diethyl ether to the DCM solution. Slow evaporation of pink solution yielded trace amounts of pink crystals of $\left[\mathrm{Cr}^{\mathrm{III}} 2(\mu-\mathrm{OH})(\mu-4-\mathrm{Cl}-\right.$ pz) $\left.)_{2}(4-\mathrm{Cl}-\mathrm{pzH})_{4} \mathrm{Cl}_{2}\right] \mathrm{Cl}$ (13). 


\subsubsection{Synthesis of $\left[m e r-\mathrm{CrCl}_{3}(4-\mathrm{Br}-\mathrm{pzH})_{3}\right](5)$}

A $25 \mathrm{~mL}$ flask was charged with $119.8 \mathrm{mg}(0.500 \mathrm{mmol})$ of $\mathrm{CrCl}_{3} \cdot 6 \mathrm{H}_{2} \mathrm{O}$ and dissolved with $15 \mathrm{~mL}$ of THF. To the obtained green solution, $264.5 \mathrm{mg}(1.806 \mathrm{mmol})$ of 4-Bromo-pyrazole (4-Br-pzH) was added and left to stir for 24 hours. Green single crystals of (5) were obtained from slow evaporation of solvent; crystal yield $75 \mathrm{mg}$ (28\%). Elemental analysis calculated for $\mathrm{C}_{9} \mathrm{H}_{9} \mathrm{Br}_{3} \mathrm{Cl}_{3} \mathrm{CrN}_{6} \cdot 0.3 \mathrm{C}_{4} \mathrm{H}_{8} \mathrm{O}: \mathrm{C}, 19.73 ; \mathrm{H}, 1.85$; N, 13.54. Found: C, 19.10; H, 1.71; N, 12.68. FTIR (cm ${ }^{-1}$, solid): $671 \mathrm{~s}, 877 \mathrm{~s}, 821 \mathrm{~m}$, 856 s, 877 m, 945 s, 1046 s, 1118 s, 1188 w, 1210 w, 1260 w, 1343 w, 1388 s, 1460 w, $3133 \mathrm{w}, 3252 \mathrm{~m}, 3306 \mathrm{w}, 3360 \mathrm{w}$. UV-Vis $(\mathrm{MeOH}) \lambda_{\max }(\varepsilon) ; \mathrm{nm}\left(\mathrm{M}^{-1} \mathrm{~cm}^{-1}\right): 451(43.0)$, 626 (27.0). ${ }^{1} \mathrm{H}$ NMR (400 MHz, $\left.\mathrm{CD}_{3} \mathrm{CN}\right) \delta 7.60$ (1), 5.44 (0.5).

\subsubsection{6. $\quad$ Synthesis of $\left[m e r-\mathrm{CrCl}_{3}(4-\mathrm{I}-\mathrm{pzH})_{3}\right](6)$.}

A translucent green solution was obtained after dissolving $111.3 \mathrm{mg}(0.418$ mmol) of $\mathrm{CrCl}_{3} \cdot 6 \mathrm{H}_{2} \mathrm{O}$ with $15 \mathrm{~mL}$ of THF in a $25 \mathrm{~mL}$ flask. Then $404.3 \mathrm{mg}(2.08 \mathrm{mmol})$ of 4-Iodo-pyrazole (4-I-pzH) was added to the stirring solution and left to react for 24 hours. Solvent was removed by reduced pressure. Dark green single crystals of (6) were obtained from diethyl ether vapor diffusion to a DCM solution; crystal yield $31.6 \mathrm{mg}$ (10\%). Anal Elemental analysis calculated for $\mathrm{C}_{9} \mathrm{H}_{9} \mathrm{Cl}_{3} \mathrm{I}_{3} \mathrm{CrN}_{6} \cdot 1.15$ $\mathrm{C}_{4} \mathrm{H}_{8} \mathrm{O}\left(\mathrm{C}_{13.6} \mathrm{H}_{18.2} \mathrm{Cl}_{3} \mathrm{CrI}_{3} \mathrm{~N}_{6} \mathrm{O}_{1.15}\right)$ : C, 19.84; H, 2.23; N, 10.21. Found: C, 19.74; H, 2.29; N, 10.07. FTIR ( $\mathrm{cm}^{-1}$, solid): 703 s, 839 m, 858 w, 939 vs, 963 w, 1052 vs, 1118 s, 1190 w, 1247 w, 1330 w, 1379 w, 1458 w, 1510 vw, 1772 vw, 2969 vw, 3132 w, 3233 m. UVVis $(\mathrm{MeOH}) \lambda_{\max }(\varepsilon) ; \mathrm{nm}\left(\mathrm{M}^{-1} \mathrm{~cm}^{-1}\right): 452$ (56.95), 618 (31.32). ${ }^{1} \mathrm{H}$ NMR $(400 \mathrm{MHz}$, $\left.\mathrm{CD}_{3} \mathrm{CN}\right) \delta 7.63$. 


\subsubsection{Synthesis of $\left[\right.$ trans $\left.-\mathrm{CrCl}_{2}(\mathrm{pzH})_{4}\right] \mathrm{Cl}(7)$.}

A $25 \mathrm{~mL}$ flask was charged with $489.0 \mathrm{mg}(4.00 \mathrm{mmol})$ of $\mathrm{CrCl}_{2}$ and dissolved in $10 \mathrm{~mL}$ of MeOH. To the translucent green solution, $1.0927 \mathrm{~g}(16.0 \mathrm{mmol})$ pyrazole $(\mathrm{pzH})$ was added. Reaction mixture was left to stir and react for 24 hours. After filtration, the solvent was removed under reduced pressure. Purple/pink single crystals of (7) were obtained from solvent laver diffusion of hexane to a DCM solution. Anal. Calcd for $\left[\mathrm{CrCl}_{2} \mathrm{pzH}_{4}\right] \mathrm{Cl}\left(\mathrm{C}_{12} \mathrm{H}_{16} \mathrm{Cl}_{3} \mathrm{CrN}_{8}\right): \mathrm{C}, 33.47 ; \mathrm{H}, 3.74 ; \mathrm{N}, 26.02$. Found: $\mathrm{C}, 34.10 ; \mathrm{H}, 3.65 ;$ N, 25.87. FTIR (cm ${ }^{-1}$, solid): $761 \mathrm{~s}, 878 \mathrm{w}, 909 \mathrm{w}, 949 \mathrm{w}, 1046 \mathrm{vs}, 1115 \mathrm{~m}, 1255 \mathrm{w}, 1277$ w, 1349 m, 1379 m, 1405 w, 1605 m, 1525 wm 1626 w, 2934 w, 2977 w, 3133 b. UVVis $(\mathrm{MeOH}) \lambda_{\max }(\varepsilon) ; \mathrm{nm}\left(\mathrm{M}^{-1} \mathrm{~cm}^{-1}\right): 410(47), 546(30)$.

\subsubsection{Crystal structure and structure refinement data}

Single crystals X-ray diffraction data were measured on a Bruker D8 QUEST CMOS system equipped with a TRIUMPH curved-crystal monochromator and a Mo Ka fine-focus tube or a Bruker APEX II area detector with graphite monochromated Mo Ka radiation $(\lambda=0.71073 \AA)$. Frames were integrated with the Bruker SAINT software package using a narrow-frame algorithm. Absorption effects were corrected using the multi-scan method (SADABS). Using Olex $2^{99}$, structures were solved by intrinsic or direct methods with ShelXT ${ }^{100}$ and refined with ShelXL ${ }^{101}$ using full-matrix least-squares minimization. All non-hydrogen atoms were refined anisotropically. Hydrogen atoms positions were calculated using the riding model. Complex 4 showed a positional disorder in one $\mathrm{Cl}$ atom and complex $\mathbf{6}$ showed a crystallographic positional disorder in 
all I atoms, resolved with the PART instruction. Disordered interstitial THF solvent molecule in $\mathbf{6}$ was resolved with SQUEEZE.

\subsubsection{EPR measurements}

Q-band EPR was recorded on an EMX plus spectrometer fitted with an EMX premium Q microwave bridge and an ER5106QTW microwave resonator operating in the $\mathrm{TE}_{012}$ mode and controlled by the Bruker Xenon software. For low-temperetaure experiments, the resonator was fitted in an Oxford CF935 dynamic continuous flow cryostat. The spectra were fitted with Easyspin V 5.2 using home-made routines. Experimental conditions: $f_{\mathrm{EPR}}=34.00 \mathrm{GHz}$, mod. ampl. $=5 \mathrm{G}_{\mathrm{pp}}, P_{\mathrm{EPR}}=1.15 \mathrm{~mW} . \mathrm{R}=\mathrm{H}$ : $T=80 \mathrm{~K} . \mathrm{R}=\mathrm{Me}: T=79 \mathrm{~K} . \mathrm{R}=\mathrm{Cl}: T=82 \mathrm{~K}$. 
Table 14. Structure refinement parameters for complexes $\mathbf{1}$ - 6.

\begin{tabular}{|c|c|c|c|c|c|c|}
\hline Compound & $(1)$ & $(2)$ & (3) & (4) & (5) & (6) \\
\hline Empirical formula & $\mathrm{C}_{9} \mathrm{H}_{12} \mathrm{Cl}_{3} \mathrm{CrN}_{6}$ & $\mathrm{C}_{12} \mathrm{H}_{18} \mathrm{Cl}_{3} \mathrm{CrN}_{6}$ & $\mathrm{C}_{12} \mathrm{H}_{18} \mathrm{Cl}_{3} \mathrm{CrN}_{6}$ & $\mathrm{C}_{9} \mathrm{H}_{9} \mathrm{Cl}_{6} \mathrm{CrN}_{6}$ & $\mathrm{C}_{9} \mathrm{H}_{9} \mathrm{Br}_{3} \mathrm{Cl}_{3} \mathrm{CrN}_{6}$ & $\mathrm{C}_{13} \mathrm{H}_{17} \mathrm{Cl}_{3} \mathrm{CrI}_{3} \mathrm{~N}_{6} \mathrm{O}$ \\
\hline Formula weight & 362.60 & 404.67 & 404.67 & 465.92 & 599.30 & 810.47 \\
\hline Temperature/K & 297.03 & 296.15 & 273.15 & 273.15 & 273.15 & 295 \\
\hline Crystal system & monoclinic & orthorhombic & orthorhombic & triclinic & monoclinic & triclinic \\
\hline Space group & $C 2 / c$ & $P_{n a 2}$ & $P 2_{1}{ }_{2} 2_{1}$ & $P-1$ & $P 2_{1} / c$ & $P-1$ \\
\hline $\mathbf{a} / \mathbf{A}$ & $9.0315(6)$ & $17.46(1)$ & $11.356(2)$ & $6.792(3)$ & $8.868(6)$ & $9.5178(8)$ \\
\hline $\mathbf{b} / \mathbf{A}$ & $14.2944(9)$ & $6.801(5)$ & $11.590(2)$ & $10.395(3)$ & $9.913(6)$ & $10.6190(9)$ \\
\hline $\mathbf{c} / \mathbf{A}$ & $11.318(1)$ & $14.86(1)$ & $13.632(3)$ & $12.218(4)$ & $20.66(1)$ & $12.613(1)$ \\
\hline $\boldsymbol{\alpha} / /^{\circ}$ & 90 & 90 & 90 & $78.81(2)$ & 90 & $78.787(2)$ \\
\hline$\beta /{ }^{\circ}$ & $97.307(1)$ & 90 & 90 & $89.62(2)$ & $100.47(2)$ & $82.592(2)$ \\
\hline$\gamma /{ }^{\circ}$ & 90 & 90 & 90 & $88.19(2)$ & 90 & $86.424(2)$ \\
\hline Volume $/ \AA^{3}$ & $1449.2(2)$ & $1764(2)$ & $1794.2(6)$ & $845.7(5)$ & $1786(2)$ & $1239.1(2)$ \\
\hline $\mathbf{Z}$ & 4 & 4 & 4 & 2 & 4 & 2 \\
\hline$\rho c a l c g / \mathrm{cm}^{3}$ & 1.662 & 1.524 & 1.498 & 1.830 & 2.229 & 2.172 \\
\hline$\mu / \mathrm{mm}^{-1}$ & 1.337 & 1.107 & 1.088 & 1.626 & 7.803 & 4.519 \\
\hline \multirow[t]{2}{*}{ Crystal size $/ \mathbf{m m}^{3}$} & $0.304 \times 0.193 \times$ & $0.1 \times 0.07 \times 0.06$ & $0.206 \times 0.098 \times$ & $0.199 \times 0.122 \times$ & $0.239 \times 0.172 \times$ & $0.259 \times 0.094 \times$ \\
\hline & 0.147 & & 0.093 & 0.081 & 0.027 & 0.073 \\
\hline $\begin{array}{l}\text { Reflections } \\
\text { collected } / 2 \Theta \max \left({ }^{\circ}\right)\end{array}$ & $9746 / 56.662$ & $18160 / 53.254$ & $30063 / 52.902$ & $16370 / 52.608$ & $28963 / 52.952$ & $17118 / 56.78$ \\
\hline $\begin{array}{l}\text { Data/restraints/ } \\
\text { parameters }\end{array}$ & $1805 / 1 / 115$ & $3704 / 1 / 203$ & $3684 / 0 / 203$ & $3424 / 0 / 244$ & $3678 / 0 / 199$ & $6164 / 0 / 288$ \\
\hline Goodness-of-fit on $F^{2}$ & 1.132 & 1.025 & 1.028 & 1.045 & 1.028 & 1.055 \\
\hline R1, wR2 [I>=2 $(\mathrm{I})]$ & $0.0282 / 0.0728$ & $0.0272 / 0.0595$ & $0.0428 / 0.0815$ & $0.0270 / 0.0629$ & $0.0366 / 0.0836$ & $0.0363 / 0.0883$ \\
\hline R1, wR2 [all data] & $0.0324 / 0.0763$ & $0.0359 / 0.0636$ & $0.0678 / 0.0894$ & $0.0358 / 0.0669$ & $0.0515 / 0.0913$ & $0.0555 / 0.0951$ \\
\hline
\end{tabular}


Table 15. Structure refinement parameters for complexes 7 - 8 .

\begin{tabular}{|c|c|c|}
\hline Compound & (7) & (8) \\
\hline Empirical formula & $\mathrm{C}_{12} \mathrm{H}_{16} \mathrm{Cl}_{3} \mathrm{CrN}_{8}$ & $\mathrm{C}_{16} \mathrm{H}_{24} \mathrm{Cl}_{3} \mathrm{CrN}_{8}$ \\
\hline Formula weight & 430.68 & 486.78 \\
\hline Temperature/K & 302.21 & 149.63 \\
\hline Crystal system & triclinic & monoclinic \\
\hline Space group & $P-1$ & $C 2 / c$ \\
\hline $\mathbf{a} / \AA$ & $8.0428(3)$ & $12.8962(9)$ \\
\hline $\mathbf{b} / \AA \AA \AA$ & $8.4370(4)$ & $13.132(1)$ \\
\hline $\mathbf{c} / \AA ̊$ & $14.9426(6)$ & $14.185(1)$ \\
\hline $\boldsymbol{\alpha} /{ }^{\circ}$ & $76.697(1)$ & 90 \\
\hline$\beta /{ }^{\circ}$ & $89.927(1)$ & $109.644(2)$ \\
\hline$\gamma /{ }^{\circ}$ & $68.369(1)$ & 90 \\
\hline Volume $/ \AA^{3}$ & $913.34(7)$ & $2262.4(3)$ \\
\hline $\mathbf{Z}$ & 2 & 4 \\
\hline$\rho c a l c g / \mathrm{cm}^{3}$ & 1.566 & 1.429 \\
\hline$\mu / \mathbf{m m}^{-1}$ & 1.077 & 0.879 \\
\hline Crystal size $/ \mathbf{m m}^{3}$ & $0.141 \times 0.101 \times 0.096$ & $0.36 \times 0.148 \times 0.135$ \\
\hline $\begin{array}{l}\text { Reflections } \\
\text { collected } / 2 \Theta \max \left({ }^{\circ}\right)\end{array}$ & $19464 / 52.84$ & $14958 / 56.848$ \\
\hline Data/restraints/parameters & $3729 / 0 / 220$ & $2839 / 0 / 139$ \\
\hline Goodness-of-fit on $\mathbf{F}^{2}$ & 1.099 & 1.043 \\
\hline R1，wR2 [I $>=2 \sigma(I)]$ & $0.0432 / 0.0898$ & $0.0480 / 0.1335$ \\
\hline R1, wR2 [all data] & $0.0591 / 0.0965$ & $0.0575 / 0.1433$ \\
\hline
\end{tabular}


Table 16. Structure refinement parameters for complexes 9 - 13 .

\begin{tabular}{|c|c|c|c|c|c|}
\hline Compound & (9) & (10) & (11) & (12) & (13) \\
\hline Empirical formula & $\mathrm{C}_{36} \mathrm{H}_{63} \mathrm{Cl}_{4} \mathrm{Cr}_{3} \mathrm{~N}_{18} \mathrm{O}_{7}$ & $\mathrm{C}_{120} \mathrm{H}_{180.01} \mathrm{Cl}_{24} \mathrm{Cr}_{12} \mathrm{~N}_{60} \mathrm{O}_{6}$ & $\mathrm{C}_{100} \mathrm{H}_{140} \mathrm{Cl}_{20} \mathrm{Cr}_{8} \mathrm{~N}_{48} \mathrm{O}_{4}$ & $\mathrm{C}_{9} \mathrm{H}_{11.5} \mathrm{Cl}_{1.5} \mathrm{CrN}_{6} \mathrm{O}_{0.5}$ & $\mathrm{C}_{72} \mathrm{H}_{68} \mathrm{Cl}_{36} \mathrm{Cr}_{8} \mathrm{~N}_{48} \mathrm{O}_{4}$ \\
\hline Formula weight & 1157.85 & 4034.19 & 3203.59 & 316.92 & 3361.94 \\
\hline Temperature/K & 295 & 273.15 & 273.15 & 273.15 & 273.15 \\
\hline Crystal system & cubic & trigonal & monoclinic & monoclinic & monoclinic \\
\hline Space group & $P a-3$ & $P-3 c 1$ & $P 2_{1} / c$ & $P 2_{1} / c$ & $P 2_{1} / c$ \\
\hline $\mathbf{a} / \AA$ & $22.6174(3)$ & $21.349(3)$ & $14.379(1)$ & $11.4398(9)$ & $14.350(2)$ \\
\hline $\mathbf{b} / \mathbf{A}$ & $22.6174(3)$ & 21.349 & $16.118(1)$ & $15.327(1)$ & $15.959(3)$ \\
\hline $\mathbf{c} / \AA$ & $22.6174(3)$ & $13.788(2)$ & $17.104(1)$ & $15.813(1)$ & $17.356(3)$ \\
\hline$\alpha / /^{\circ}$ & 90 & 90 & 90 & 90 & 90 \\
\hline$\beta /{ }^{\circ}$ & 90 & 90 & $95.513(2)$ & $93.818(2)$ & $96.769(5)$ \\
\hline$\gamma /{ }^{\circ}$ & 90 & 120 & 90 & 90 & 90 \\
\hline Volume $/ \AA^{3}$ & $11569.9(5)$ & $5442(2)$ & $3945.8(5)$ & $2766.4(4)$ & $3947(1)$ \\
\hline $\mathbf{Z}$ & 8 & 1 & 1 & 8 & 1 \\
\hline$\rho_{\text {calc }} \mathbf{g} / \mathrm{cm}^{3}$ & 1.329 & 1.231 & 1.348 & 1.522 & 1.414 \\
\hline $\boldsymbol{\mu} / \mathbf{m m}^{-1}$ & 0.794 & 0.921 & 0.925 & 1.111 & 1.190 \\
\hline $\mathbf{F}(000)$ & 4808.0 & 2064.0 & 1640.0 & 1288.0 & 1672.0 \\
\hline Crystal size $/ \mathbf{m m}^{3}$ & $0.126 \times 0.083 \times 0.06$ & $0.151 \times 0.131 \times 0.053$ & $0.126 \times 0.083 \times 0.059$ & $0.133 \times 0.104 \times 0.077$ & $0.156 \times 0.144 \times 0.056$ \\
\hline $\begin{array}{l}2 \Theta \text { range for data } \\
\text { collection/ }{ }^{\circ}\end{array}$ & 5.974 to 52.702 & 5.83 to 49.446 & 5.798 to 49.574 & 5.808 to 52.902 & 5.718 to 52.702 \\
\hline Reflections collected & 187939 & 80864 & 60939 & 53854 & 82500 \\
\hline $\begin{array}{l}\text { Data/restraints/para } \\
\text { meters }\end{array}$ & $3940 / 0 / 211$ & $3101 / 1 / 173$ & $6759 / 0 / 416$ & $5672 / 10 / 366$ & $8001 / 0 / 383$ \\
\hline $\begin{array}{l}\text { Goodness-of-fit on } \\
\mathrm{F}^{2}\end{array}$ & 1.147 & 1.075 & 1.021 & 1.030 & 1.040 \\
\hline $\mathrm{R}_{1}, \mathrm{wR}_{2}[\mathrm{I}>=\mathbf{2 \sigma}(\mathrm{I})]$ & $0.0919 / 0.2367$ & $0.0662 / 0.1970$ & $0.0597 / 0.1172$ & $0.0563 / 0.1190$ & $0.0494 / 0.1317$ \\
\hline $\mathbf{R}_{1}, \mathbf{w R}_{2}$ [all data] & $0.1525 / 0.2668$ & $0.0954 / 0.2145$ & $0.1134 / 0.1354$ & $0.0978 / 0.1347$ & $0.0713 / 0.1432$ \\
\hline
\end{tabular}




\section{Chapter 3: Chromium mixed-ligand complexes with $\mathrm{Cr}_{3}\left(\mu_{3}-\mathrm{O}\right)$ cores}

\section{Synthesis of trinuclear chromium mixed-ligand formate-pyrazolate complexes}

\subsection{Introduction}

Mixed pyrazolate-carboxylate complex with formula $\left[\mathrm{Co}_{3} \mathrm{O}(\mu-\mathrm{OAc})_{3}(\mu-\right.$ $\left.\mathrm{pz})_{3}(\mathrm{pzH})_{3}\right]\left(\mathrm{PF}_{6}\right)$ has been previously synthesized and characterized. ${ }^{102}$ Paramagnetic shifts in the NMR spectra were not observed as consequence of the diamagnetic nature of the all LS-Co(III) trinuclear centers. Mixed ligand complexes of cobalt show a reversible reduction and an irreversible oxidation. Increasing the amount of bridging pyrazolate ligands in these complexes alters their redox potential.

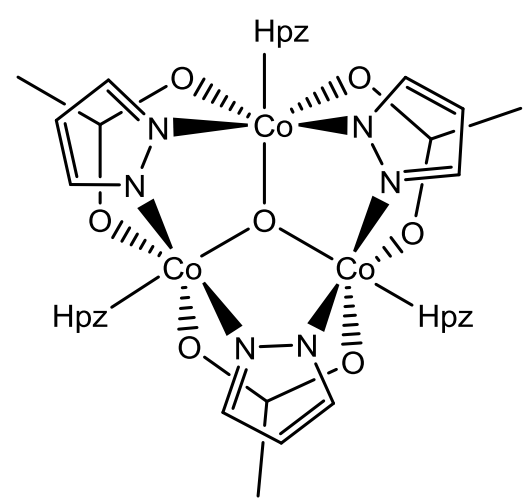

Scheme 10. Structure of $\left[\mathrm{Co}_{3}\left(\mu_{3}-\mathrm{O}\right)(\mu-\mathrm{OAc})_{3}(\mu-\mathrm{pz})_{3}(\mathrm{pzH})_{3}\right]^{-102}$

Here we present the synthesis of new chromium mixed-ligand formate-pyrazolate complexes, their crystal structure, electronic absorption spectra, and NMR studies. 


\subsection{Results and discussion}

\subsubsection{Synthesis}

The use of high boiling point solvent and the use of $\mathrm{Cr}\left(\mathrm{NO}_{3}\right)_{3} \cdot 9 \mathrm{H}_{2} \mathrm{O}$ yielded higher nuclearity complexes. Hydrolysis of DMF and deprotonation of the pyrazole produced trinuclear formate-pyrazolate mixed-ligand complexes with molecular formula

$\left[\mathrm{Cr}_{3}^{\mathrm{III}}\left(\mu_{3}-\mathrm{O}\right)(\mu-4-\mathrm{Me}-\mathrm{pz})_{3}\left(\mu-\mathrm{O}_{2} \mathrm{CH}\right)_{3}(\mathrm{DMF})_{3}\right]\left(\mathrm{PF}_{6}\right) \quad$ (14), $\quad\left[\mathrm{Cr}_{3}^{\mathrm{III}}\left(\mu_{3}-\mathrm{O}\right)(\mu-\mathrm{pz})_{3}(\mu-\right.$ $\left.\left.\mathrm{O}_{2} \mathrm{CH}\right)_{3}(\mathrm{DMF})_{3}\right]\left(\mathrm{PF}_{6}\right)(\mathbf{1 5})$, and $\left[\mathrm{Cr}_{3}^{\mathrm{III}}{ }_{3}\left(\mu_{3}-\mathrm{O}\right)(\mu-4-\mathrm{Cl}-\mathrm{pz})_{3}\left(\mu-\mathrm{O}_{2} \mathrm{CH}\right)_{3}(\mathrm{DMF})_{3}\right]\left(\mathrm{NO}_{3}\right)$ (16). Synthetic method was designed from reported chromium carboxylate complex synthesis. ${ }^{103}$ Both, the microwave and thermally assisted syntheses produced the complexes; the latter required longer reaction time. Low yields are characteristic of these syntheses. The use of $\mathrm{Cr}\left(\mathrm{NO}_{3}\right)_{3} \cdot 9 \mathrm{H}_{2} \mathrm{O}$ prevented the formation of mononuclear complexes with form $\left[\right.$ mer- $\left.\mathrm{CrCl}_{3}\left(\mathrm{pzH}^{*}\right)_{3}\right]$.

\subsubsection{Crystallographic data}

Structures of complexes 14,15 , and 16 were determined by single-crystal XRD; refinement parameters are summarized in Table 22. Complexes $\mathbf{1 4}$ and $\mathbf{1 5}$ crystallized with one third of a molecule in the asymmetric unit, whereas complex 16 crystallized with a whole molecule in the asymmetric unit. Complexes 13 and 15 crystallized in trigonal $R-3$ and $P-31 c$ space groups, respectively. Complex 16 crystallized in monoclinic $P 2_{1} / c$ space group. The presence of monoanionic counter ion and the $\mathrm{Cr} \cdots \mu_{3}-\mathrm{O}$ bonds distances are consistent with all $\mathrm{Cr}^{\mathrm{III}}$ complexes. Complexes 14 and $\mathbf{1 5}$ crystallized with $\mathrm{PF}_{6}^{-}$and complex 16 with $\mathrm{NO}_{3}^{-}$counter ion. Complexes also crystallized with dimethylamine, product of the hydrolysis of DMF. 
Three six-coordinate chromium centers are bridged by an oxygen atom forming a $\mathrm{Cr}_{3}\left(\mu_{3}-\mathrm{O}\right)$ core. Complexes $\mathbf{1 4}$ and $\mathbf{1 5}$ have a 3-fold axis though the $\mu_{3}-\mathrm{O}$ atom. The $\mathrm{Cr}_{3}\left(\mu_{3}-\mathrm{O}\right)$ core is supported by six bridging ligands and three terminally coordinated DMF molecules. Formate and pyrazolate ligands face opposite directions, causing structural differences to the all-carboxylate complexes. For all complexes, the average $\mathrm{Cr}-\mathrm{N}$ bond lengths in the $\mu$-pyrazolate are shorter than the $\mathrm{Cr}-\mathrm{O}$ in the $\mu$-formate (Table 17). The addition of pyrazolate bridging ligands shortens the $\mathrm{Cr} \cdots \mathrm{Cr}$ distance compared the carboxylate analogs because of the ligand's rigidity differences (Table 18). The central $\mu_{3}-\mathrm{O}$ atom slightly protrudes from the $\mathrm{Cr}_{3}$ plane towards the formate ligands in the mixed-ligand complexes because of their electron deficient properties compared to the pyrazolate groups. In contrast, in the all-carboxylate trimers, the central $\mu_{3}-\mathrm{O}$ atom is located on the $\mathrm{Cr}_{3}$ plane. The distances between $\mu_{3}-\mathrm{O}$ atom and the $\mathrm{Cr}_{3}$ plane are $0.23460(1), 0.23395(2)$, and $0.22426(2) \AA$ in $\mathbf{1 4}, \mathbf{1 5}$, and 16, respectively.

Table 17. Selected interatomic distances $(\AA)$ for complexes 14 - 16.

\begin{tabular}{lccc} 
& \multicolumn{3}{c}{ Compound } \\
\cline { 2 - 4 } \multicolumn{1}{c}{ Bond } & $\mathbf{1 4}$ & $\mathbf{1 5}$ & $\mathbf{1 6}$ \\
\hline $\mathrm{Cr}-\mu_{3}-\mathrm{O}$ & $1.873(1)$ & $1.874(2)$ & $1.871(8)-1.883(8)$ \\
$\mathrm{Cr} \cdots \mathrm{Cr}$ & $3.2190(2)$ & $3.2198(3)$ & $3.2235(3)-3.2372(3)$ \\
$\mathrm{Cr}-\mathrm{N}$ & $2.011(5)-2.031(6)$ & $2.00(1)-2.03(1)$ & $2.00(1)-2.04(1)$ \\
$\mu_{3}-\mathrm{O} \cdots \mathrm{Cr}_{\text {plane }}$ & $0.23460(1)$ & $0.23395(2)$ & $0.22426(2)$
\end{tabular}

Table 18. $\mathrm{Cr} \cdots \mathrm{Cr}$ distances $(\AA)$ and angles $\left(^{\circ}\right)$ for selected trinuclear chromium carboxylate complexes.

\begin{tabular}{lccc} 
& \multicolumn{1}{c}{ Distance $(\AA)$} & Angle $\left(^{\circ}\right)$ & \\
\cline { 2 - 4 } \multicolumn{1}{c}{ Complex } & $\mathbf{C r} \cdots \mathbf{C r}$ & $\mathbf{C r}-\boldsymbol{\mu}_{3^{-}-\mathbf{O}}$ & Ref \\
\hline$\left[\mathrm{Cr}_{3} \mathrm{O}\left(\mathrm{O}_{2} \mathrm{CPh}\right)_{5}\left(\mathrm{H}_{2} \mathrm{~N}-\mathrm{sao}\right)(\mathrm{EtOH})_{2}\right]$ & $3.359(1), 3.312(1), 3.210(1)$ & $1.905(3)$ & 104 \\
{$\left[\mathrm{Cr}_{3} \mathrm{O}\left(\mu-\mathrm{O}_{2} \mathrm{CCH}_{2} \mathrm{CH}\right)_{6}(\mathrm{Hpz})_{3}\right]^{+}$} & $3.284(1)-3.305(1)$ & $1.900(6)$ & 105 \\
{$\left[\mathrm{Cr}_{3} \mathrm{O}\left(\mu-\mathrm{O}_{2} \mathrm{CPh}(\mathrm{OH})\right)_{7}\left(\mathrm{H}_{2} \mathrm{O}\right)_{2}\right]$} & $3.310(2), 3.301(2), 3.294(1)$ & $1.906(4)$ & 106 \\
{$\left[\mathrm{Cr}_{3} \mathrm{O}\left(\mu-\mathrm{C}_{3} \mathrm{H}_{5} \mathrm{O}_{2}\right)_{6}\left(\mathrm{H}_{2} \mathrm{O}\right)_{3}\right]^{+}$} & $3.256(1)-3.288(1)$ & $1.891(3)$ & 107
\end{tabular}




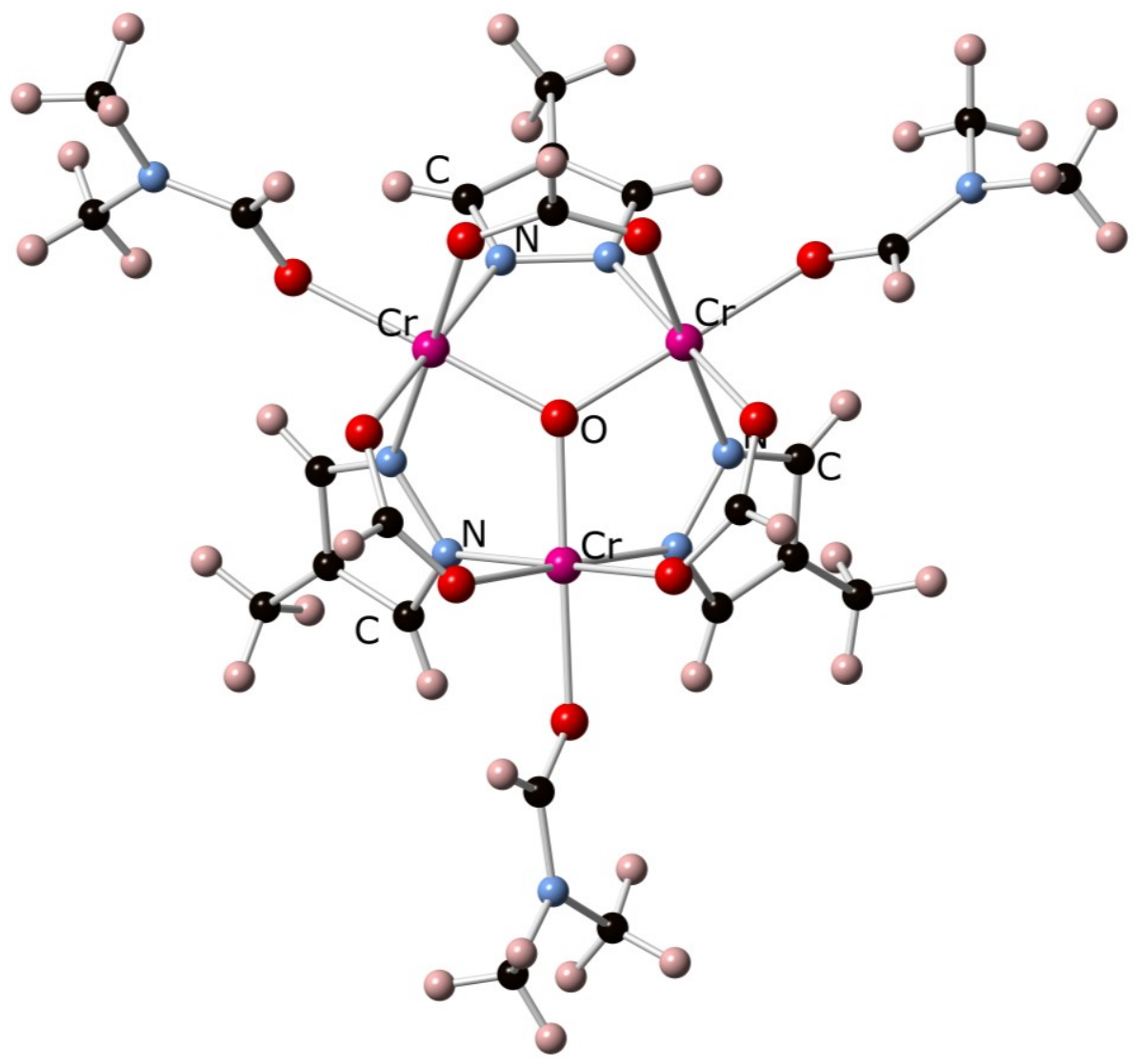

Figure 41. Ball and stick representation structure of $\left[\mathrm{Cr}_{3}^{\mathrm{III}}\left(\mu_{3}-\mathrm{O}\right)(\mu-4-\mathrm{Me}-\mathrm{pz})_{3}(\mu-\right.$ $\left.\left.\mathrm{O}_{2} \mathrm{CH}\right)_{3}(\mathrm{DMF})_{3}\right]^{+}(\mathbf{1 4})$. 


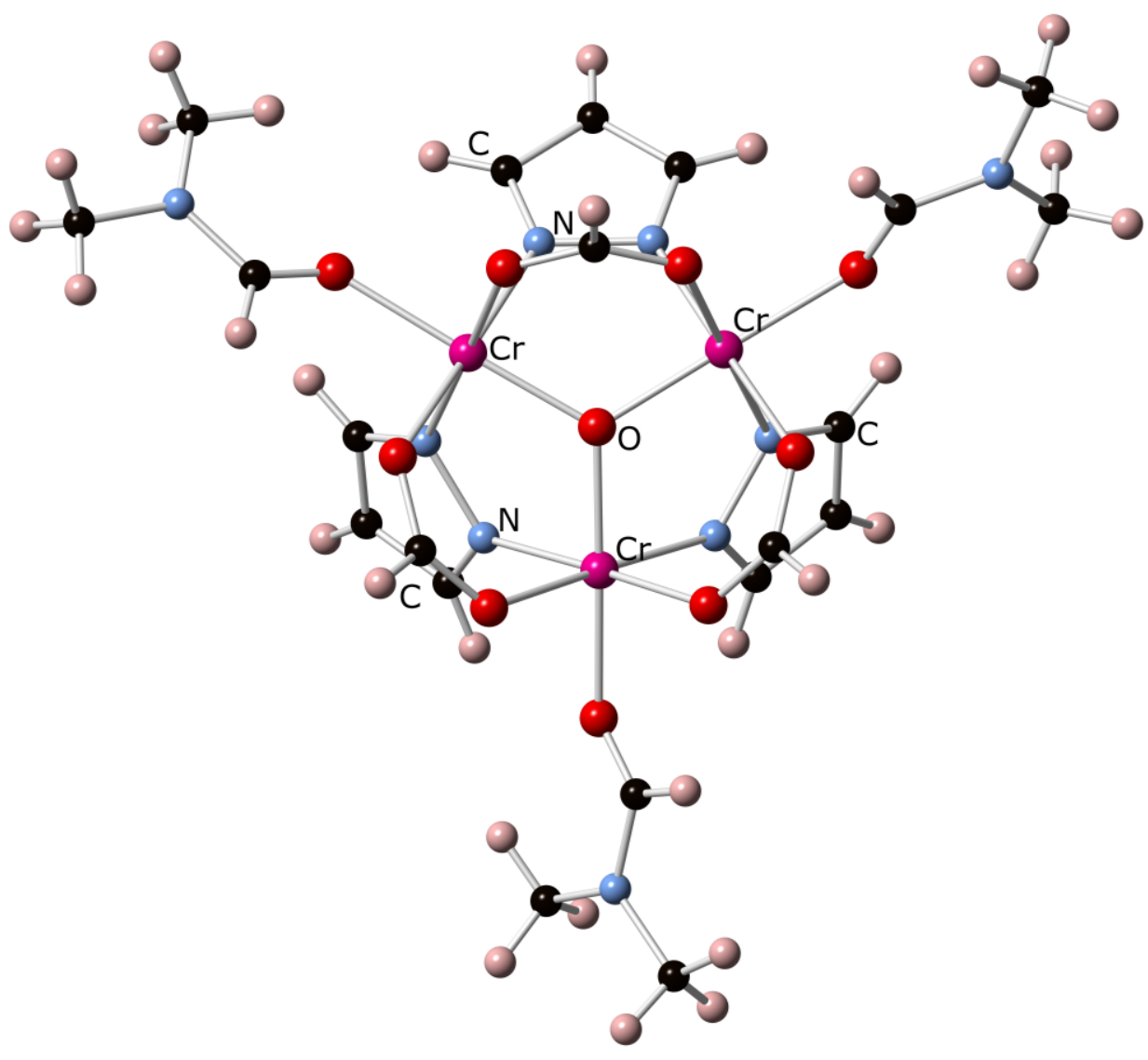

Figure 42. Ball and stick representation structure of $\left[\mathrm{Cr}_{3}^{\mathrm{III}}{ }_{3}\left(\mu_{3}-\mathrm{O}\right)(\mu-\mathrm{pz})_{3}(\mu-\right.$ $\left.\left.\mathrm{O}_{2} \mathrm{CH}\right)_{3}(\mathrm{DMF})_{3}\right]^{+}(\mathbf{1 5})$. 


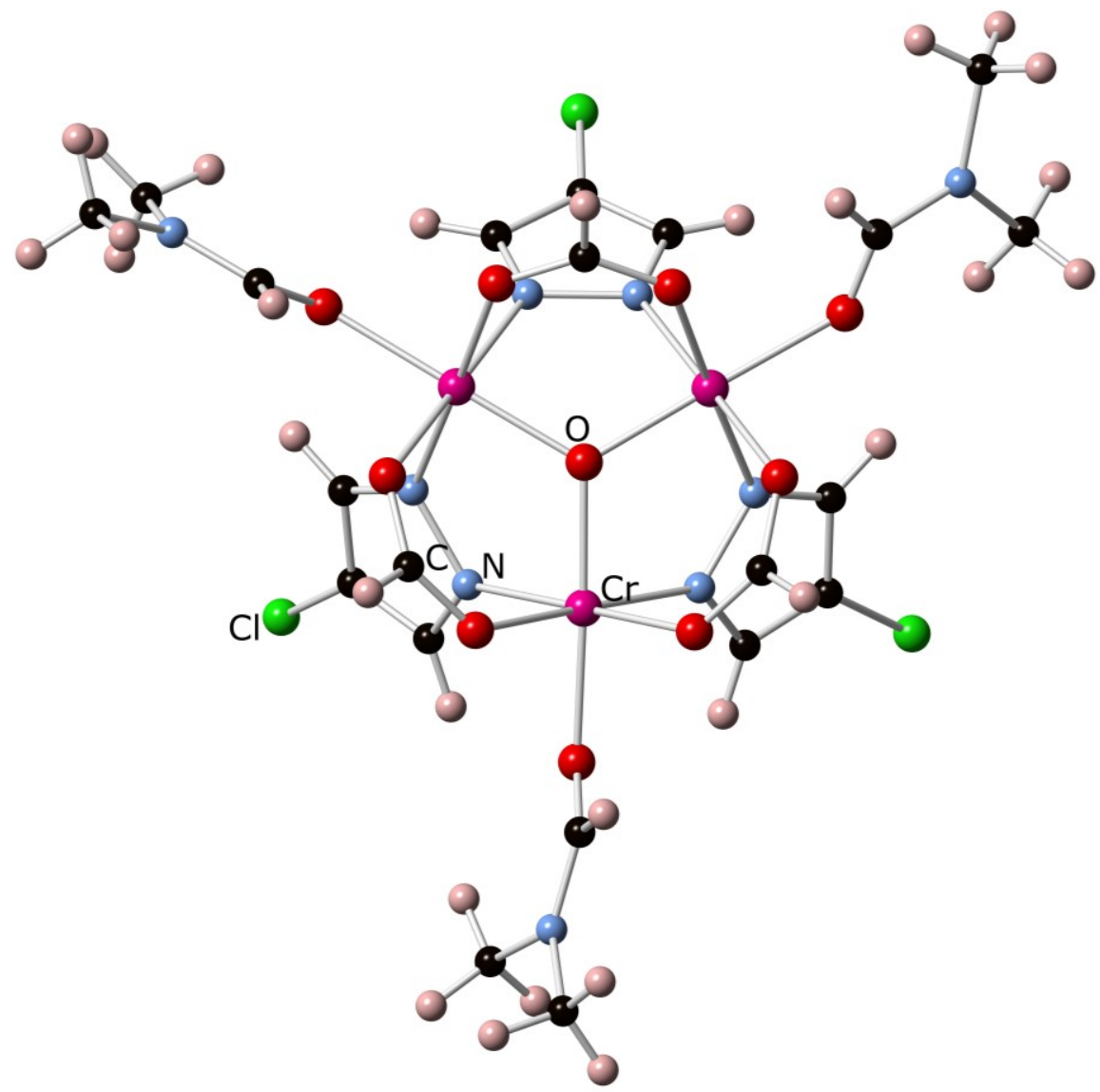

Figure 43. Ball and stick representation structure of $\left[\mathrm{Cr}_{3}^{\mathrm{III}}{ }_{3}\left(\mu_{3}-\mathrm{O}\right)(\mu-4-\mathrm{Cl}-\mathrm{pz})_{3}(\mu-\right.$ $\left.\left.\mathrm{O}_{2} \mathrm{CH}\right)_{3}(\mathrm{DMF})_{3}\right]^{+}$(16). 


\subsubsection{Electrochemistry and absorption spectra}

The presence of pyrazolate ligands and the various accessible oxidation states of chromium lead us to assume that these complexes would have reversible electrochemical properties, similar to the cobalt(II) analog. Contrary to expectations, trinuclear mixedligand chromium(III) complexes with formula $\left[\mathrm{Cr}_{3}^{\mathrm{III}}{ }_{3}\left(\mu_{3}-\mathrm{O}\right)(\mu-4-\mathrm{R}-\mathrm{pz})_{3}(\mu-\right.$ $\left.\left.\mathrm{O}_{2} \mathrm{CH}\right)_{3}(\mathrm{DMF})_{3}\right]^{+}(\mathrm{R}=\mathrm{Me}, \mathrm{H}, \mathrm{Cl})$ showed no reversible processes in the $-1 \mathrm{~V}$ to $1 \mathrm{~V}$ window in DCM.

The electronic spectra of trinuclear oxo-bridged chromium(III) complexes have been studied extensively with different acetate ligands. Usually, these exhibit two spinallowed bands corresponding to ${ }^{4} \mathrm{~A}_{2 \mathrm{~g}}-{ }^{4} \mathrm{~T}_{2 \mathrm{~g}}(\mathrm{~F})$ and ${ }^{4} \mathrm{~A}_{2 \mathrm{~g}}-{ }^{4} \mathrm{~T}_{1 \mathrm{~g}}(\mathrm{~F})$ transition, where small energy shifts are observed from the variation of bridging ligands. ${ }^{108,109} \mathrm{UV}-\mathrm{Vis}$ of $\mathbf{1 4} \mathbf{- 1 6}$ shows two allowed transitions with similar energy listed in Table 20. Small energy shifts are observed from the variation of the pyrazole substitution.

Table 19. Electronic absorption spectral $\left(\mathrm{cm}^{-1}\right)$ data for trinuclear mixed-ligand acetate complexes. ${ }^{108}$

\begin{tabular}{|c|c|c|}
\hline \multirow[b]{2}{*}{ Complex } & \multicolumn{2}{|c|}{ Observed transition from ${ }^{4} \mathrm{~A}_{2 \mathrm{~g}}(\mathrm{~F})$ to } \\
\hline & $\begin{array}{c}{ }^{4} \mathrm{~T}_{2 \mathrm{~g}}(\mathrm{~F}) \\
\left(v_{1}, 10 \mathrm{Dq}\right)\end{array}$ & $\begin{array}{c}{ }^{4} \mathrm{~T}_{1 \mathrm{~g}}(\mathrm{~F}) \\
\left(\mathrm{v}_{2}\right)\end{array}$ \\
\hline$\left[\mathrm{Cr}_{3} \mathrm{O}(\mathrm{OAc})_{3}\left(\mathrm{OOCC}_{13} \mathrm{H}_{27}\right)_{3}\right](\mathrm{OAc}) \cdot 3 \mathrm{MeOH}$ & 17155 & 22620 \\
\hline$\left[\mathrm{Cr}_{3} \mathrm{O}(\mathrm{OAc})_{3}\left(\mathrm{OOCC}_{15} \mathrm{H}_{31}\right)_{3}\right](\mathrm{OAc}) \cdot 3 \mathrm{MeOH}$ & 16775 & 22545 \\
\hline$\left[\mathrm{Cr}_{3} \mathrm{O}(\mathrm{OAc})_{3}\left(\mathrm{OOCC}_{17} \mathrm{H}_{35}\right)_{3}\right](\mathrm{OAc}) \cdot 3 \mathrm{MeOH}$ & 16795 & 23055 \\
\hline$\left[\mathrm{Cr}_{3} \mathrm{O}(\mathrm{SOCPh})_{3}\left(\mathrm{OOCC}_{13} \mathrm{H}_{27}\right)_{3}\right](\mathrm{OAc}) \cdot 3 \mathrm{MeOH}$ & 17800 & 22850 \\
\hline$\left[\mathrm{Cr}_{3} \mathrm{O}(\mathrm{SOCPh})_{3}\left(\mathrm{OOCC}_{15} \mathrm{H}_{31}\right)_{3}\right](\mathrm{OAc}) \cdot 3 \mathrm{MeOH}$ & 16730 & 23220 \\
\hline$\left[\mathrm{Cr}_{3} \mathrm{O}(\mathrm{SOCPh})_{3}\left(\mathrm{OOCC}_{17} \mathrm{H}_{35}\right)_{3}\right](\mathrm{OAc}) \cdot 3 \mathrm{MeOH}$ & 16830 & 22860 \\
\hline
\end{tabular}


Table 20. Electronic absorption data $\left(\mathrm{cm}^{-1}\right)$ for $\mathbf{1 4}$ - 16.

\begin{tabular}{ccc}
\multicolumn{1}{c}{ Complex } & \multicolumn{2}{c}{ Observed transition } \\
& $\left(v_{1}, 10 \mathrm{Dq}\right)$ & $\left(v_{2}\right)$ \\
\hline$\left[\mathrm{Cr}^{\mathrm{III}}{ }_{3}\left(\mu_{3}-\mathrm{O}\right)(\mu-\mathrm{pz})_{3}\left(\mu-\mathrm{O}_{2} \mathrm{CH}\right)_{3}(\mathrm{DMF})_{3}\right]\left(\mathrm{PF}_{6}\right)$ & 18587 & 24096 \\
{$\left[\mathrm{Cr}^{\mathrm{III}}{ }_{3}\left(\mu_{3}-\mathrm{O}\right)(\mu-4-\mathrm{Me}-\mathrm{pz})_{3}\left(\mu-\mathrm{O}_{2} \mathrm{CH}\right)_{3}(\mathrm{DMF})_{3}\right]\left(\mathrm{PF}_{6}\right)$} & 18248 & 24154 \\
{$\left[\mathrm{Cr}_{3}{ }_{3}\left(\mu_{3}-\mathrm{O}\right)(\mu-4-\mathrm{Cl}-\mathrm{pz})_{3}\left(\mu-\mathrm{O}_{2} \mathrm{CH}\right)_{3}(\mathrm{DMF})_{3}\right]\left(\mathrm{NO}_{3}\right)$} & 18518 & 23980
\end{tabular}

\subsubsection{Nuclear magnetic resonance}

There are many examples of trinuclear $\mathrm{Cr}^{\mathrm{III}}$ carboxylate complexes that are NMR active due to the intermediate spin relaxation rate that makes their NMR spectra possible to record. Nuclear magnetic resonance (NMR) has been used to study the chemical structure and formation mechanisms of assemblies with general formula $\left[\mathrm{Cr}^{\mathrm{III}}{ }_{3}\left(\mu_{3}-\mathrm{O}\right)(\mu-\right.$ $\left.\left.\mathrm{O}_{2} \mathrm{CR}\right)_{6}(\mathrm{~L})_{3}\right]$. The octahedrally-coordinated $\mathrm{Cr}(\mathrm{III})$ centers in trinuclear complexes, are paramagnetic with a magnetic moment of $3.14 \mu_{\mathrm{B}}$, compared to the calculated $3.87 \mu_{\mathrm{B}}$ for mononuclear species. ${ }^{110}$ Reduction of magnetic moment as a result of antiferromagnetic coupling between metal centers allows NMR spectra to be observed. Results show that coordinated bridging acetate ligands have paramagnetically shifted signals compared to free acetate. ${ }^{95}$

Spectra for complexes 14 - $\mathbf{1 6}$ showed two broad peaks shifted downfield and a broad peak shifted upfield. Peak integration ratio of 3:1 confirms signals shifted furthest downfield corresponding to the coordinated DMF methyl groups and the broad peak at around $1.7 \mathrm{ppm}$ to the $\mathrm{H}^{3} / \mathrm{H}^{5}$ proton of the bridging pyrazolate. The disappearance of peak at $27.7 \mathrm{ppm}$ for complex 14 and appearance of $-43.09 \mathrm{ppm}$ for complex 15 confirms the assignment of the 4-Me and $\mathrm{H}^{4}$ protons, respectively (Figure 45). Spectra of 14 and 15 showed additional peaks attributed to impurities and other synthesis solvents, peak assignments was supported with spectra of 16 and are listed in Table 21. 


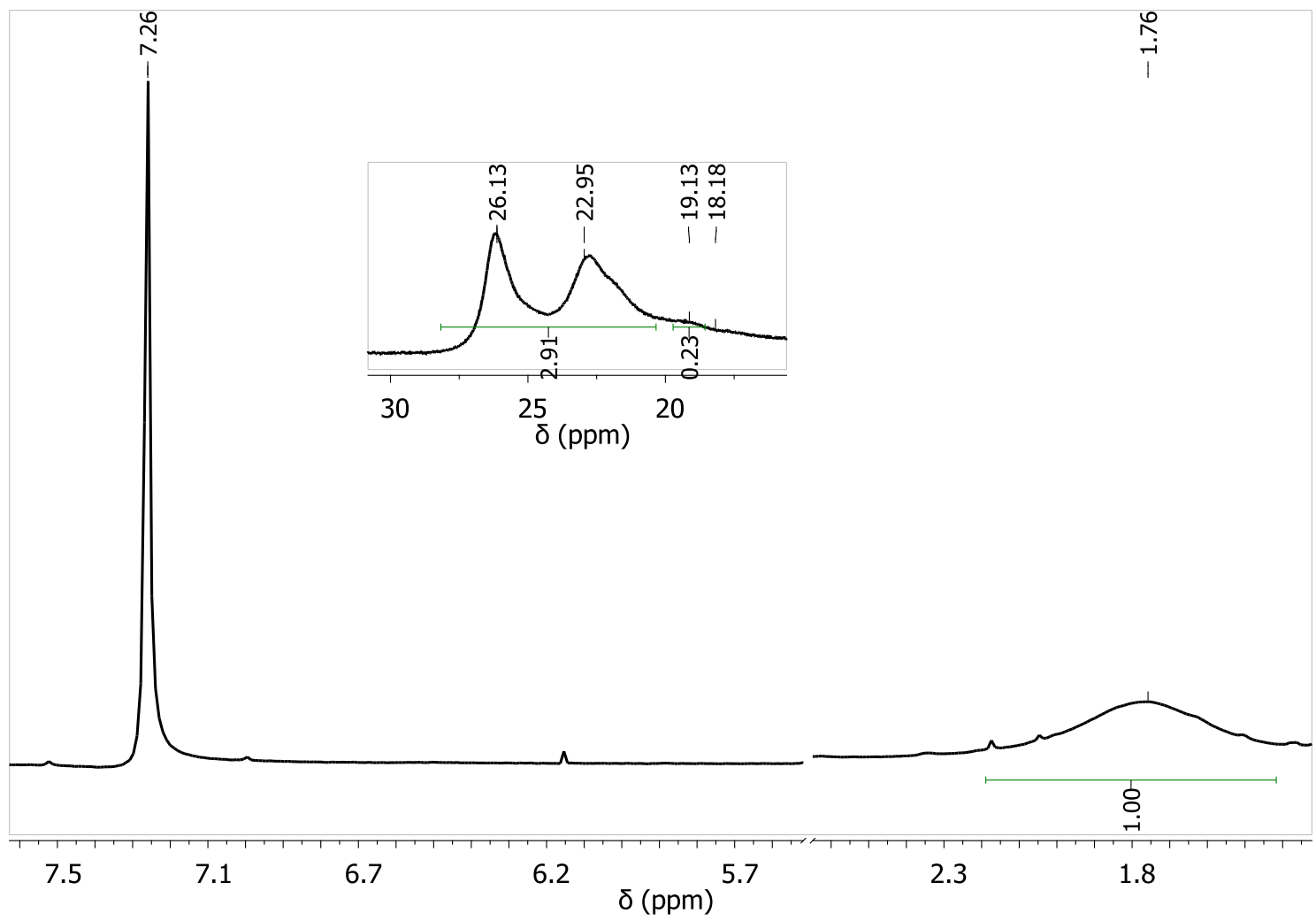

Figure 44. ${ }^{1} \mathrm{H}$ NMR of complex 16 in $\mathrm{CDCl}_{3}$ at $400 \mathrm{MHz}$. Spectrum referenced to the residual solvent proton resonance.

Table 21. ${ }^{1} \mathrm{H}$ NMR chemical shifts for complexes $\mathbf{1 4}, \mathbf{1 5}$, and 16 in ppm.

\begin{tabular}{cl|cccc} 
Compound & \multicolumn{2}{c}{ Me-DMF } & $\mathrm{H}^{3} / \mathrm{H}^{5}-\mathrm{pzH}$ & $\mathrm{H}^{4}-\mathrm{pzH}$ & 4-Me-pzH \\
\hline 14 & 23.01 & 26.18 & 1.60 & - & 27.70 \\
15 & 23.01 & 26.01 & 1.78 & -43.09 & - \\
16 & 22.95 & 26.13 & 1.76 & - & -
\end{tabular}



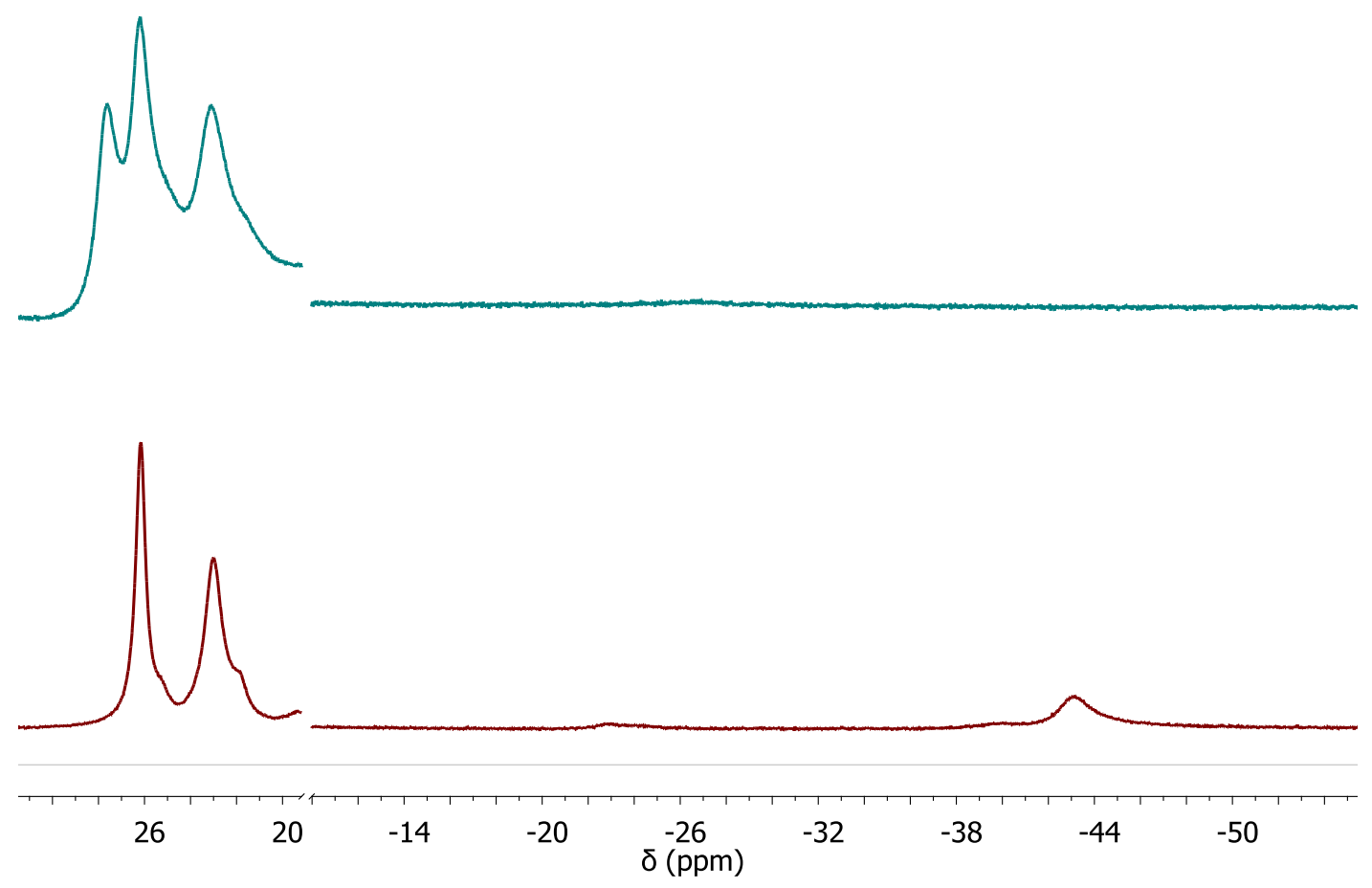

Figure 45. ${ }^{1} \mathrm{H}$ NMR of complex 14 (top) and 15 (bottom) in $\mathrm{CDCl}_{3}$ at $400 \mathrm{MHz}$. Spectra referenced to the residual solvent proton resonance.

The extent of paramagnetic shifts in inorganic compounds is determined by the nature of metal-ligand interaction. ${ }^{83}$ Shifts might come from either pseudo-contact or contact shift interactions. ${ }^{84}$ Similar to the analogous all-carboxylate complexes, the mixed-ligand pyrazolate-formate $\mathrm{Cr}^{\mathrm{III}}$ complexes show that contact interactions are the predominant pathway, which are dominated by electron spin delocalization from the metal atom to the ligands. ${ }^{110}$ Spin delocalization can follow the $\sigma$ (through $\sigma$ bonds) or $\pi$ (through $\pi$ bonds) mechanisms. Spin delocalization in analogous bridging carboxylate complexes is known to follows both the $\sigma$ or $\pi$ mechanism; with the $\pi$ mechanism being the more predominant. ${ }^{11}$ 
Substitution of the methyl group (14) by a proton (15) results in the methyl proton signal being shifted in the opposite direction of the proton, consistent with a $\pi$-spin delocalization. Similar effect has been observed for the ${ }^{1} \mathrm{H}$ and ${ }^{2} \mathrm{H}$ NMR of [Cr $\left.\mathrm{Cr}_{3} \mathrm{O}\left(\mathrm{O}_{2} \mathrm{CR}\right)_{6} \mathrm{~L}_{3}\right]$ ( $\mathrm{R}=\mathrm{Me}$, Ethyl, $\mathrm{Ph}$, 4-Me-Ph and $\mathrm{L}=\mathrm{H}_{2} \mathrm{O}$, py, 2-Mepy, 3-Mepy, 4Mepy). ${ }^{110}$ Methyl groups from the coordinated DMF have the longest bond distance to the metal center and are shifted farthest downfield. Similar behavior is observed for trinuclear $\mathrm{Cr}^{\mathrm{III}}$ complexes with picoline ligands, where the magnitude of paramagnetic shifts show no direct dependence on the bond distance between the metal and ligand. ${ }^{112}$ Satellite peak at $20.0 \mathrm{ppm}$ should correspond to the remaining proton of the terminally coordinated DMF molecules, following the $\sigma$ spin delocalization, while remaining satellite peak at $-22.5 \mathrm{ppm}$ corresponds to proton of bridging formate ligands.

\subsection{Conclusions}

The reaction of $\mathrm{Cr}\left(\mathrm{NO}_{3}\right)_{3} \cdot 9 \mathrm{H}_{2} \mathrm{O}$ and 4-R-pyrazole $(\mathrm{R}=\mathrm{H}, \mathrm{Me}, \mathrm{Cl})$ in DMF yielded new trinuclear mixed-ligand pyrazolate-formate $\mathrm{Cr}^{\mathrm{III}}$ complexes. Solvent served as a base for pyrazole deprotonation. Solvent are also part of the final product where DMF molecules are terminally coordinated to the chromium metal centers. Hydrolysis provided formate bridging ligands and dimethylamine that co-crystallized with the final product. Paramagnetic complexes were characterized using NMR, where the alternating chemical shifts on the pyrazole ligand was indicative of delocalization of unpaired electron density from the metal to the ligands. Mixed-ligand complexes do not show electrochemical properties due to lability of formate ligands. All-pyrazolate chromium complexes should be attainable with the use of a non hydrolyzing solvent. 


\subsection{Experimental section}

\subsubsection{Materials}

Chromium nitrate nonahydrate, pyrazole ligands 4-R-pz $(\mathrm{R}=\mathrm{H}, \mathrm{Me}, \mathrm{Cl})$ and DMF solvent were purchased from Fisher Scientific. All syntheses were carried out using a CEM Discover SP-Microwave synthesizer, at $130{ }^{\circ} \mathrm{C}$ with 100 watts of microwave power for 10 minutes.

\subsubsection{Instrumentation}

Refer to section 2.4.2 for details of instrumentation.

\subsubsection{Synthesis and characterization}

\subsubsection{Synthesis of $\left[\mathrm{Cr}_{3}\left(\mu_{3}-\mathrm{O}\right)\left(\mu-\mathrm{O}_{2} \mathrm{CH}\right)_{3}(\mu-4-\mathrm{Me}-\mathrm{pz})_{3}(\mathrm{DMF})_{3}\right] \mathrm{PF}_{6}$ (14)}

A microwave-fitted test tube was charged with $209.1 \mathrm{mg}(0.522 \mathrm{mmol})$ of $\mathrm{Cr}\left(\mathrm{NO}_{3}\right)_{3} \cdot 9 \mathrm{H}_{2} \mathrm{O}$ and $129.2 \mu \mathrm{L}(1.569 \mathrm{mmol})$ of 4-Me-pzH. Purple solution was obtained after dissolution of reagents with approximately $1 \mathrm{~mL}$ of DMF. Dark pink solution was obtained after microwave; $202 \mathrm{mg}$ of $\mathrm{TBAPF}_{6}$ were added, followed by addition of water and extraction with DCM. X-Ray suitable crystals were obtained from hexane layer

diffusion into a DCM solution. ${ }^{1} \mathrm{H}$ NMR $\left(400 \mathrm{MHz}, \mathrm{CDCl}_{3}\right) / \mathrm{ppm}: \delta 1.60\left(\mathrm{~s}, 6 \mathrm{H}, \mathrm{H}^{3} / \mathrm{H}^{5}\right)$, 23.30 (s, 9H, DMF-Me), 26.18 (s, 9H, DMF-Me), 27.72 (s, 9H, 4-Me). 


\subsubsection{Synthesis of $\left[\mathrm{Cr}_{3}\left(\mu_{3}-\mathrm{O}\right)\left(\mu-\mathrm{O}_{2} \mathrm{CH}\right)_{3}(\mu-\mathrm{pz})_{3}(\mathrm{DMF})_{3}\right] \mathrm{PF}_{6}(15)$}

A microwave-fitted test tube was charged with $282.2 \mathrm{mg}(0.705 \mathrm{mmol})$ of $\mathrm{Cr}\left(\mathrm{NO}_{3}\right)_{3} \cdot 9 \mathrm{H}_{2} \mathrm{O}$ and $144.2 \mathrm{mg}(2.118 \mathrm{mmol})$ of pyrazole. Purple solution was obtained after dissolution of reagents with approximately $1 \mathrm{~mL}$ of DMF. Reaction was set at 130 ${ }^{\circ} \mathrm{C}$ with 100 watts of microwave power for 10 minutes. Dark pink solution was obtained after microwave; $136 \mathrm{mg}$ of $\mathrm{TBAPF}_{6}$ were added, followed by addition of water and extraction with DCM. X-Ray suitable crystals were obtained from diethyl ether diffusion into a DCM solution. ${ }^{1} \mathrm{H}$ NMR (400 MHz, $\left.\mathrm{CDCl}_{3}\right) / \mathrm{ppm}$ : $\delta-41.22\left(\mathrm{~s}, 3 \mathrm{H}, \mathrm{H}^{4}\right), 1.78(\mathrm{~s}, 6 \mathrm{H}$, $\left.\mathrm{H}^{3} / \mathrm{H}^{5}\right), 23.03$ (s, 9H, DMF-Me), 26.17 (s, 9H, DMF-Me).

\subsubsection{Synthesis of $\left[\mathrm{Cr}_{3}\left(\mu_{3}-\mathrm{O}\right)\left(\mu-\mathrm{O}_{2} \mathrm{CH}\right)_{3}(\mu-4-\mathrm{Cl}-\mathrm{pz})_{3}(\mathrm{DMF})_{3}\right] \mathrm{PF}_{6}(16)$}

A microwave-fitted test tube was charged with $225.5 \mathrm{mg}(0.563 \mathrm{mmol})$ of $\mathrm{Cr}\left(\mathrm{NO}_{3}\right)_{3} \cdot 9 \mathrm{H}_{2} \mathrm{O}$ and $172.6 \mathrm{mg}(1.692 \mathrm{mmol})$ of 4-Cl-pzH. Purple solution was obtained after dissolution of reagents with approximately $1 \mathrm{~mL}$ of DMF. Pink solution after microwave was precipitated with diethyl ether and dried in vacuum. X-Ray suitable crystals were obtained from diethyl ether diffusion into a DCM solution. ${ }^{1} \mathrm{H}$ NMR (400 MHz, $\mathrm{CDCl}_{3}$ )/ppm: $\delta 1.78\left(\mathrm{~s}, 6 \mathrm{H}, \mathrm{H}^{3} / \mathrm{H}^{5}\right), 22.85$ (s, 9H, DMF-Me), 26.24 (s, 9H, DMF$\mathrm{Me})$.

\subsubsection{Crystal structure}

Refer to section 2.4.4 for details on data refinement. 
Table 22. Structure refinement parameters for complexes 14 - 16.

\begin{tabular}{|c|c|c|c|}
\hline Compound & (14) & (15) & (16) \\
\hline Empirical formula & $\mathrm{C}_{30} \mathrm{H}_{60} \mathrm{Cr}_{3} \mathrm{~F}_{6} \mathrm{~N}_{10} \mathrm{O}_{10} \mathrm{P}$ & $\mathrm{C}_{27} \mathrm{H}_{49} \mathrm{Cr}_{3} \mathrm{~F}_{6} \mathrm{~N}_{10} \mathrm{O}_{10} \mathrm{P}$ & $\mathrm{C}_{21} \mathrm{H}_{30} \mathrm{Cl}_{3} \mathrm{Cr}_{3} \mathrm{~N}_{10} \mathrm{O}_{13}$ \\
\hline Formula weight & 1021.86 & 974.74 & 892.90 \\
\hline Temperature/K & $293(2)$ & 150.9 & 200.0 \\
\hline Crystal system & trigonal & trigonal & monoclinic \\
\hline Space group & $R-3$ & $P-31 c$ & $P 2_{1} / c$ \\
\hline $\mathbf{a} / \AA$ & $12.7744(7)$ & $12.5372(9)$ & $16.720(1)$ \\
\hline $\mathbf{b} / \AA$ & $12.7744(7)$ & $12.5372(9)$ & $20.108(2)$ \\
\hline $\mathbf{c} / \AA$ & $47.259(3)$ & $28.642(2)$ & $12.920(1)$ \\
\hline $\boldsymbol{\alpha} / /^{\circ}$ & 90 & 90 & 90 \\
\hline$\beta / /^{\circ}$ & 90 & 90 & $107.880(2)$ \\
\hline$\gamma /{ }^{\circ}$ & 120 & 120 & 90 \\
\hline Volume $/ \AA^{3}$ & $6678.8(8)$ & $3898.9(6)$ & $4134.2(6)$ \\
\hline $\mathbf{Z}$ & 5.99994 & 3.99996 & 4 \\
\hline$\rho_{\text {calc }} g / \mathrm{cm}^{3}$ & 1.524 & 1.661 & 1.435 \\
\hline$\mu / \mathbf{m m}^{-1}$ & 0.841 & 0.956 & 1.031 \\
\hline $\mathbf{F}(000)$ & 3186.0 & 2008.0 & 1812.0 \\
\hline Crystal size $/ \mathbf{m m}^{3}$ & $0.219 \times 0.13 \times 0.09$ & $0.22 \times 0.152 \times 0.134$ & $0.323 \times 0.245 \times 0.213$ \\
\hline $2 \Theta$ range for data collection/ & 5.668 to 52.762 & 6.5 to 49.446 & 6.258 to 50.054 \\
\hline Reflections collected & 27971 & 54327 & 48299 \\
\hline Data/restraints/parameters & $3048 / 6 / 186$ & $2231 / 0 / 179$ & $7256 / 0 / 457$ \\
\hline Goodness-of-fit on $\mathbf{F}^{2}$ & 1.124 & 1.077 & 1.022 \\
\hline $\mathbf{R}_{1}, \mathbf{w R}_{2}[\mathbf{I}>=\mathbf{2 \sigma}(\mathrm{I})]$ & $0.0831 / 0.2030$ & $0.0970 / 0.2354$ & $0.0862 / 0.2175$ \\
\hline $\mathbf{R}_{1}, \mathbf{w R}_{2}$ [all data] & $0.1131 / 0.2162$ & $0.1383 / 0.2649$ & $0.1488 / 0.2643$ \\
\hline
\end{tabular}




\section{Chapter 4: Chromium pyrazolate complexes with $\mathrm{Cr}_{3}\left(\mu_{3}-\mathrm{O}\right)$ cores}

\section{Pyrazolate-supported $\mathrm{Cr}_{3}\left(\mu_{3}-\mathrm{O}\right)$ cores}

\subsection{Introduction}

The structural parallel between transition-metal carboxylate and pyrazolate complexes with the same nuclearity have been explored with $\mathrm{Pd},{ }^{29,30} \mathrm{Pt}^{29} \mathrm{Fe},{ }^{33}$ and $\mathrm{Cu} .{ }^{113}$ The metal-core motif of complex remains almost unchanged when one or more bridging carboxylate ligands are replaced by pyrazolates. ${ }^{102}$ The electronic structure of a metal complex along with the metal-to-metal electronic and magnetic communication are affected by the donor capacity and orbital symmetry of bridging ligands. ${ }^{114}$

To date, reported chromium(III) carboxylate complexes are not electrochemically active. Chromium heterocyclic thionates share a similar core structure as the trinuclear complexes of form $\left[\mathrm{Cr}_{3}^{\mathrm{III}}\left(\mu_{3}-\mathrm{O}\right)\left(\mu-\mathrm{O}_{2} \mathrm{CR}\right)_{6}(\mathrm{~L})_{3}\right]$, with a $\mu_{3}-\mathrm{O}$ central core, which show electrochemical properties. ${ }^{115}$ Mixed-valent complexes of various transition metals have been used to determine the vibronic interactions and its effect in double exchange in complexes of iron, manganese, cobalt and chromium. ${ }^{55}$ In the case of chromium, mixedvalent carboxylate complex with cyanopyridine affords a $\mathrm{d}^{3}-\mathrm{d}^{3}-\mathrm{d}^{4}$ configuration, which is the simplest electronic configuration accessible so far with the $\mathrm{Cr}_{3}\left(\mu_{3}-\mathrm{O}\right)$ motif. ${ }^{116}$ Pyrazolate complexes of chromium with $\mathrm{Cr}_{3}\left(\mu_{3}-\mathrm{O}\right)$ cores should have structural similarities to that of all-carboxylate and electrochemical properties similar to that of trinuclear thionates. 


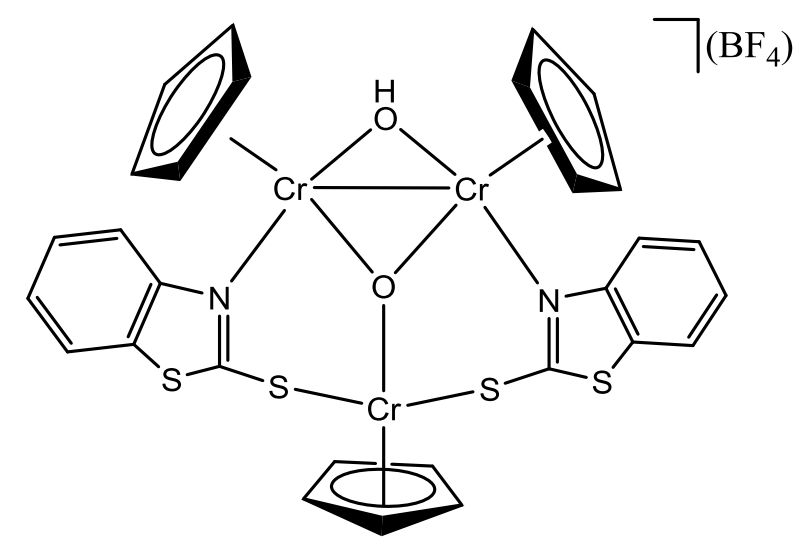

Scheme 11. $\left[\mathrm{Cp}_{3} \mathrm{Cr}_{3}(\mu-\mathrm{OH})\left(\mu_{3}-\mathrm{O}\right)\left(\mu-\eta^{2}-\mathrm{S}_{2} \mathrm{CN}\left(\mathrm{C}_{6} \mathrm{H}_{4}\right)\right)_{2}\right] \mathrm{BF}_{4}{ }^{115}$

Here we present the synthesis and characterization of the first all-pyrazolate chromium(III) complexes. This new family of complexes shows reversible oxidation processes, being the first electrochemically active trinuclear chromium complexes that access a $\mathrm{d}^{3}-\mathrm{d}^{3}-\mathrm{d}^{2}$ configuration.

\subsection{Results and discussion}

\subsubsection{Synthesis and crystal structure}

Reaction of $\mathrm{Cr}\left(\mathrm{NO}_{3}\right)_{3} \cdot 9 \mathrm{H}_{2} \mathrm{O}$, 4-Cl-pzH, $\mathrm{Et}_{3} \mathrm{~N}$, and $\mathrm{Ph}_{4} \mathrm{PCl}$ in butyronitrile at $100^{\circ} \mathrm{C}$ results in a pink solution. Pink single crystals of product $\left(\mathrm{Ph}_{4} \mathrm{P}\right)_{2}\left[\mathrm{Cr}_{3}\left(\mu_{3}-\mathrm{O}\right)(\mu-4-\right.$ Cl-pz $\left.{ }_{6} \mathrm{Cl}_{3}\right](\mathbf{1 7})$ were recrystallized from $\mathrm{MeOH}$ slow evaporation or $\mathrm{DCM} / \mathrm{Et}_{2} \mathrm{O}$ vapor diffusion. One pot synthesis yielded copious amount of green precipitate, which can be $\mathrm{CrCl}_{3}$ or $\left[\right.$ mer- $\left.\mathrm{CrCl}_{3}(4-\mathrm{Cl}-\mathrm{pzH})_{3}\right]$. Reaction was optimized by heating the $\mathrm{Cr}\left(\mathrm{NO}_{3}\right)_{3} \cdot 9 \mathrm{H}_{2} \mathrm{O}$, 4-Cl-pzH, and base until color change, forming an intermediate trinuclear complex of form $\left[\mathrm{Cr}_{3}{ }_{3}{ }_{3}\left(\mu_{3}-\mathrm{O}\right)(\mu-4-\mathrm{Cl}-\mathrm{pz})_{6} \mathrm{X}_{3}\right]$. Final compound is produced after addition of $\mathrm{Cl}^{-}$or $\mathrm{Br}^{-}$terminal ligand, for $\mathbf{1 7}$ and $\mathbf{1 8}$, respectively. 
Crystallographic structure refinement data for $\mathbf{1 7}$ and $\mathbf{1 8}$ are listed in Table 25. Crystal structures of $\mathbf{1 7}$ and $\mathbf{1 8}$ contain three octahedral $\mathrm{Cr}^{\mathrm{III}}$ centers bridged by a $\mu_{3-}$ oxygen atom, forming a $\mathrm{Cr}_{3}\left(\mu_{3}-\mathrm{O}\right)$ core, isostructural to the analogous $\mathrm{Fe}_{3}\left(\mu_{3}-\mathrm{O}\right)$ core. $\mathrm{Six}$ bridging pyrazolate ligands and three terminal ligands support the $\mathrm{Cr}_{3}\left(\mu_{3}-\mathrm{O}\right)$ core. Complexes 17 and 18 crystallized in a orthorhombic Pbcn space group with half molecule and a single $\mathrm{Ph}_{4} \mathrm{P}^{+}$counterion in the asymmetric unit. At room temperature complexes have a 2 -fold axis running along the $\mathrm{O}-\mathrm{Cr}-\mathrm{Cl}$ bonds, with two long and one short $\mathrm{Cr} \cdots \mathrm{Cr}$ distances and $\mathrm{Cr}-\mathrm{O}$ bonds listed in Table 23. Both $\mathrm{Cr} \cdots \mathrm{Cr}$ distance and $\mathrm{Cr}-\mathrm{O}$ bond lengths are shorter compared to $\left[\mathrm{Fe}_{3}\left(\mu_{3}-\mathrm{O}\right)\left(\mu-4-\mathrm{NO}_{2}-\mathrm{pz}\right)_{6} \mathrm{Cl}_{3}\right]^{2-}[3.267(1)$ and 3.280(1) $\AA]^{33}$ and the reported carboxylate analogs (Table 24). At low temperature, the symmetry is reduced to $\mathrm{Pna}_{2}$ for $\mathbf{1 7}$ and 18. Low temperatures limit the thermal motion within the structure causing the 2-fold symmetry axis running through the $\mathrm{O}-\mathrm{Cr}-\mathrm{X}$ $[\mathrm{X}=\mathrm{Cl}(\mathbf{1 7}), \mathrm{Br}(\mathbf{1 8})]$ to disappear.

Table 23. Selected bond distances $(\AA)$ and angles $\left(^{\circ}\right)$ for $\mathbf{1 7}$ and $\mathbf{1 8 .}$

\begin{tabular}{ccccc} 
& \multicolumn{5}{c}{ Compound } \\
\cline { 2 - 5 } Bond & $\mathbf{2 9 3 ~ K}$ & $\mathbf{1 0 0 ~ K}$ & $\mathbf{2 9 6 ~ K}$ & $\mathbf{1 5 0 ~ K}$ \\
\cline { 2 - 5 } $\mathrm{Cr} \cdots \mathrm{Cr}$ & $3.198(2)$ & $3.2052(6)$ & $3.1896(1)$ & $3.203(1)$ \\
& $3.204(1)$ & $3.2172(6)$ & $3.2042(1)$ & $3.201(1)$ \\
& & $3.2014(7)$ & & $3.213(1)$ \\
$\mathrm{Cr}-\mathrm{X}$ & $2.323(2)$ & $2.326(4)$ & $2.47753(8)$ & $2.470(1)$ \\
& $2.325(2)$ & $2.322(4)$ & $2.4757(1)$ & $2.473(1)$ \\
& & $2.318(4)$ & & $2.475(1)$ \\
$\mathrm{Cr}-\mathrm{N}$ & $2.034(4)-2.065(4)$ & $2.04(1)-2.08(1)$ & $2.0395(1)-2.0781(1)$ & $2.041(6)-2.072(6)$ \\
$\mathrm{Cr}-\mathrm{O}$ & $1.843(4)$ & $1.864(9)$ & $1.84878(7)$ & $1.853(4)$ \\
& $1.852(2)$ & $1.847(7)$ & $1.84643(6)$ & $1.843(4)$ \\
& & $1.846(10)$ & & $1.858(4)$ \\
$\mathrm{Cr}-\mathrm{O}-\mathrm{Cr}$ & $120.3(1)$ & $119.21(2)$ & $120.264(1)$ & $120.5(2)$ \\
& $119.5(3)$ & $120.35(1)$ & $119.471(3)$ & $120.2(2)$ \\
& & $120.37(1)$ & & $119.3(2)$
\end{tabular}


Table 24. $\mathrm{Cr} \cdots \mathrm{Cr}(\AA)$ distance for selected all-carboxylate chromium complexes.

\begin{tabular}{|c|c|c|c|}
\hline \multirow[b]{2}{*}{ Complex } & \multicolumn{2}{|c|}{ Distance $(\AA)$} & \multirow[b]{2}{*}{ Ref } \\
\hline & $\mathrm{Cr} \cdots \mathrm{Cr}$ & $\mathrm{Cr}-\mathrm{O}\left(\mu_{3}\right)$ & \\
\hline$\left[\mathrm{Cr}_{3} \mathrm{O}\left(\mu-\mathrm{O}_{2} \mathrm{CCH}_{2} \mathrm{CH}_{3}\right)_{6}(\mathrm{Hpz})_{3}\right]^{+}$ & $3.284(1)-3.305(1)$ & $1.895(2)-1.907(2)$ & 105 \\
\hline$\left[\mathrm{Cr}_{3} \mathrm{O}\left(\mu-\mathrm{O}_{2} \mathrm{CCH}_{2} \mathrm{CH}_{3}\right)_{6}\left(\mathrm{H}_{2} \mathrm{O}\right)_{3}\right]^{+}$ & $3.2863-3.289$ & $1.891(3)$ & 107 \\
\hline$\left[\mathrm{Cr}_{3} \mathrm{O}\left(\mu-\mathrm{O}_{2} \mathrm{CCH}_{3}\right)_{6}\left(\mathrm{H}_{2} \mathrm{O}\right)_{3}\right]^{+}$ & $3.278(1)-3.288(1)$ & $1.885(3)-1.902(4)$ & 117 \\
\hline$\left[\mathrm{Cr}_{3} \mathrm{O}\left(\mu-\mathrm{O}_{2} \mathrm{CH}\right)_{6}\left(\mathrm{H}_{2} \mathrm{O}\right)_{3}\right]^{+}$ & $3.257(8)$ & $1.881(5)$ & 118 \\
\hline
\end{tabular}

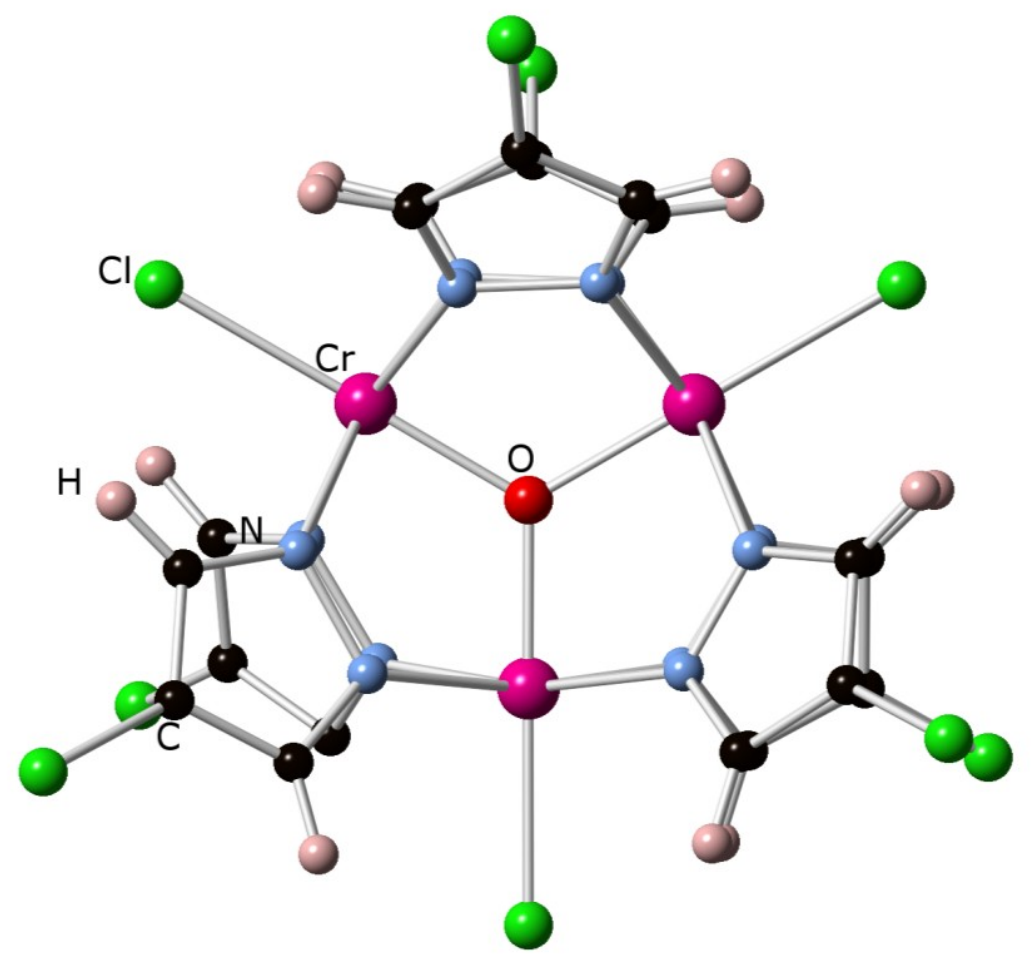

Figure 46. Ball-and-stick representation $\left[\mathrm{Cr}_{3}\left(\mu_{3}-\mathrm{O}\right)\left(\mu-4-\mathrm{Cl}-\mathrm{pz}_{6} \mathrm{Cl}_{3}\right]^{-2}(\mathbf{1 7})\right.$. Counter ions are omitted for clarity. 


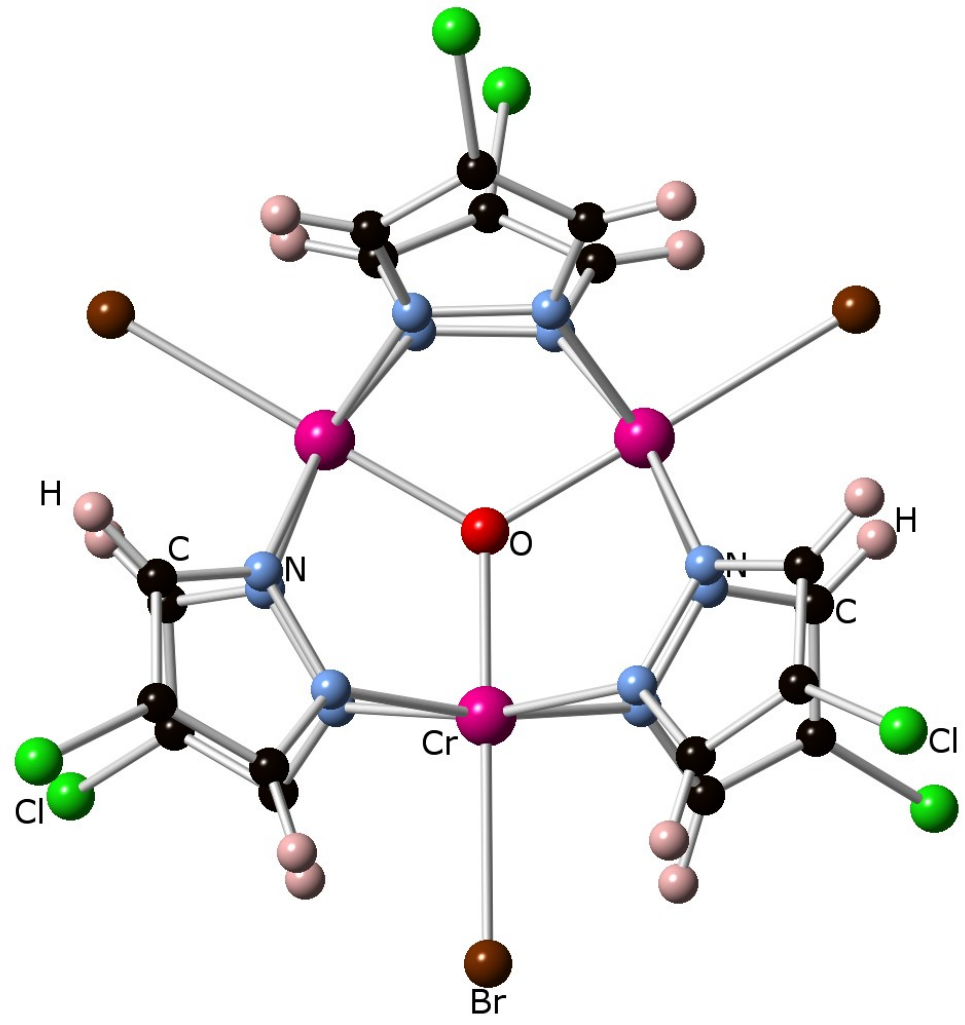

Figure 47. Ball-and-stick representation $\left[\mathrm{Cr}_{3}\left(\mu_{3}-\mathrm{O}\right)(\mu-4-\mathrm{Cl}-\mathrm{pz})_{6} \mathrm{Br}_{3}\right]^{-2}(\mathbf{1 8})$. Counter ions are omitted for clarity.

\subsubsection{Electrochemistry}

Cyclic voltammogram (CV) and differential pulse voltammogram (PDV) were collected for complex 17. Since analogous iron pyrazolate complexes have redox properties and chromium exists in various oxidation states, we expect complex 17 to show reversible electrochemical processes. The $\mathrm{CV}$ of $\left(\mathrm{Ph}_{4} \mathrm{P}\right)_{2}\left[\mathrm{Cr}_{3}\left(\mu_{3}-\mathrm{O}\right)(\mu-4-\mathrm{Cl}-\mathrm{pz})_{6} \mathrm{Cl}_{3}\right]$ (17) shows a reversible oxidation process for a $\mathrm{Cr}_{3}^{\mathrm{III}} / \mathrm{Cr}^{\mathrm{IV}} \mathrm{Cr}^{\mathrm{III}}{ }_{2}$ species at $0.502 \mathrm{~V}$ (Figure 48). The peak-to-peak separation $\left(\Delta \mathrm{E}_{\mathrm{p}}\right)$ for this reversible process was $62 \mathrm{mV}$, which corresponds to a one-electron ${ }^{\dagger}$ transfer process. $^{119,120}$ Oxidation potential is similar to that of $\left[\mathrm{Cp}_{3} \mathrm{Cr}_{3}\left(\mu_{2}-\mathrm{OH}\right)\left(\mu_{3}-\mathrm{O}\right)\left(\mu_{2}-\eta^{2}-\mathrm{S}_{2} \mathrm{CN}\left(\mathrm{C}_{6} \mathrm{H}_{4}\right)\right)_{2}\right] \mathrm{BF}_{4}\left(\mathrm{E}_{1 / 2}=+0.59 \mathrm{~V} v s \mathrm{Fc}^{+} / \mathrm{Fc}\right){ }^{115}$

\footnotetext{
${ }^{\dagger}$ For a reversible process, $\mathrm{n}$ (number of electrons) can be calculated from: $\Delta \mathrm{E}_{\mathrm{p}}=\mathrm{E}_{\mathrm{pa}}-\mathrm{E}_{\mathrm{pc}} \approx 0.059 / \mathrm{n}$
} 


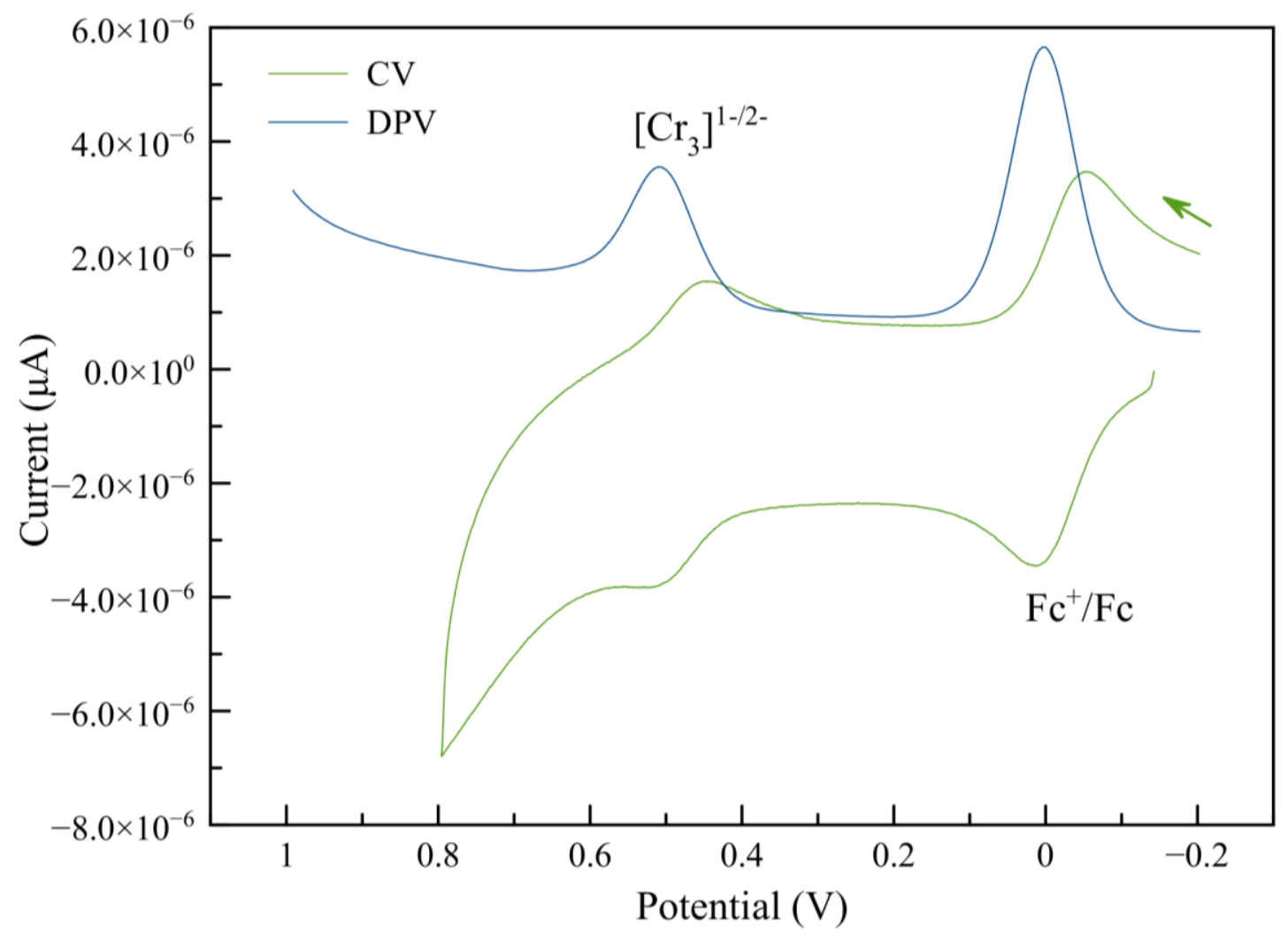

Figure 48. Differential Pulse Voltammogram (DPV) (blue) and Cyclic Voltammogram (CV) (green) of $17 v s . \mathrm{Fc}^{+} / \mathrm{Fc} .\left[\mathrm{Cr}_{3}\right]^{1-2-}\left(\mathrm{E}_{1 / 2}=0.502 \mathrm{~V}\right) .150 \mathrm{mV} / \mathrm{s}$ sweep.

Cyclic voltammogram (CV) and differential pulse voltammogram (PDV) of $\left(\mathrm{Ph}_{4} \mathrm{P}\right)_{2}\left[\mathrm{Cr}_{3}\left(\mu_{3}-\mathrm{O}\right)\left(\mu-4-\mathrm{Cl}-\mathrm{pz}_{6} \mathrm{Br}_{3}\right]\right.$ (18) are illustrated in Figure 49. An additional oxidation processes is observed for complex 18. Irregular DPV peaks are suggestive of irreversible or quasi reversible processes. Two reversible oxidation processes will access $\mathrm{Cr}_{3} \mathrm{III}_{3} / \mathrm{Cr}^{\mathrm{IV}} \mathrm{Cr}^{\mathrm{IIII}}{ }_{2}\left(\mathrm{E}_{1 / 2}=0.332 \mathrm{~V}\right)$ and $\mathrm{Cr}^{\mathrm{IIII}} / \mathrm{Cr}^{\mathrm{IV}}{ }_{2} \mathrm{Cr}^{\mathrm{III}}\left(\mathrm{E}_{1 / 2}=0.584 \mathrm{~V}\right)$ species. The reduction of potential is indicative that the substitution of $\mathrm{Cl}^{-}$with $\mathrm{Br}^{-}$causes the oxidation to become easier and a second oxidation process to be accessible. 


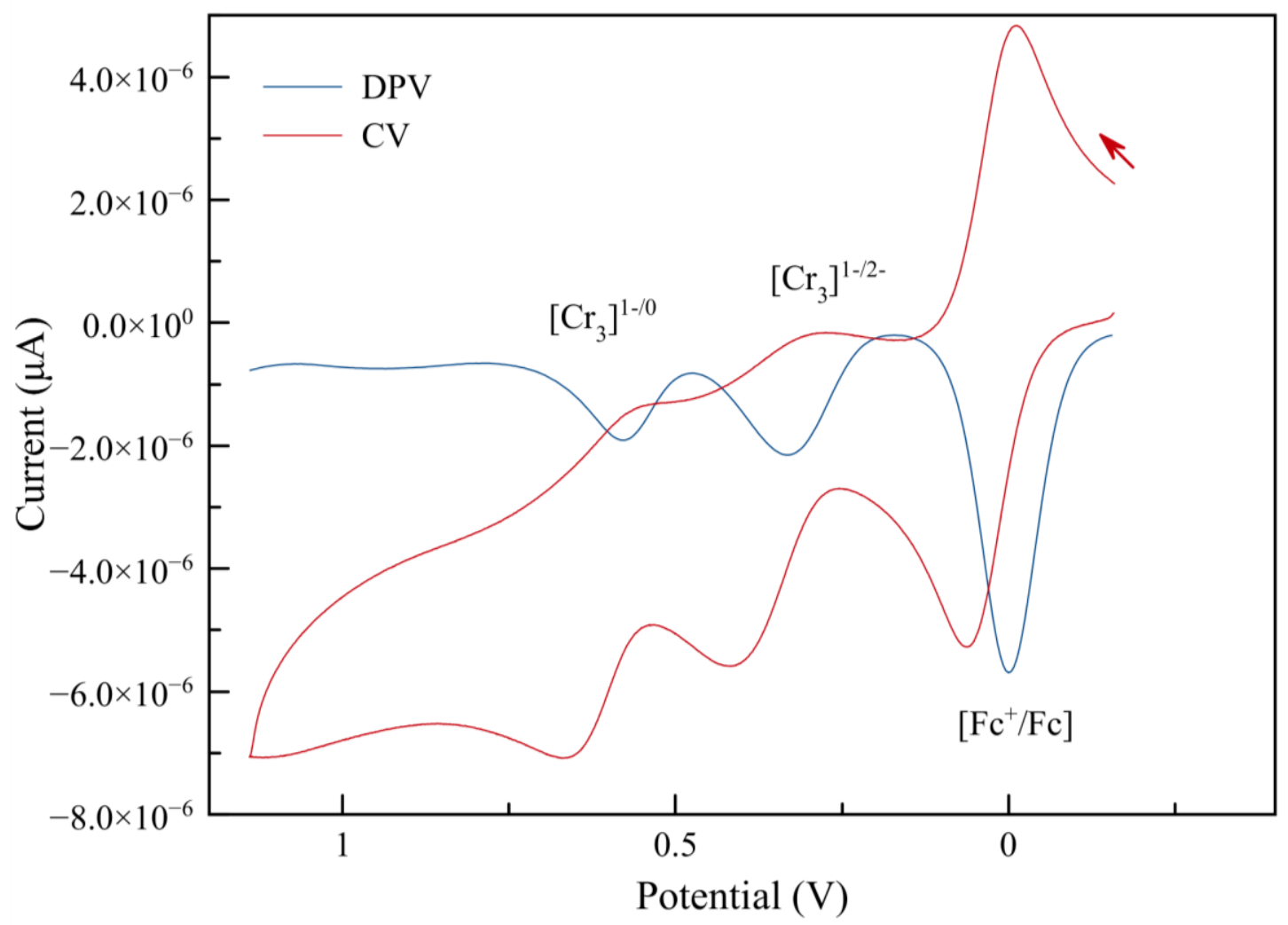

Figure 49. Differential Pulse Voltammogram (DPV) (blue) and Cyclic Voltammogram (CV) (red) of $18 v s . \mathrm{Fc}^{+} / \mathrm{Fc} .\left[\mathrm{Cr}_{3}\right]^{1-/ 2-}\left(\mathrm{E}_{1 / 2}=0.332 \mathrm{~V}\right),\left[\mathrm{Cr}_{3}\right]^{1-0}\left(\mathrm{E}_{1 / 2}=0.584 \mathrm{~V}\right)$

Different heights of cathodic and anodic peaks from the CV suggest these processes are not fully reversible. Differential pulse voltammetry in forward and reverse (Figure 50), showed both oxidation processes in both directions, indicating that the processes are not fully reversible in the CV timescale. In the forward DPV, the anodic sweep confirms both oxidation peaks, with the same height. In the reverse DPV, a cathodic sweep is applied, and the two peaks are observed with different peak heights, suggesting that the second oxidation process is not fully reversible. 


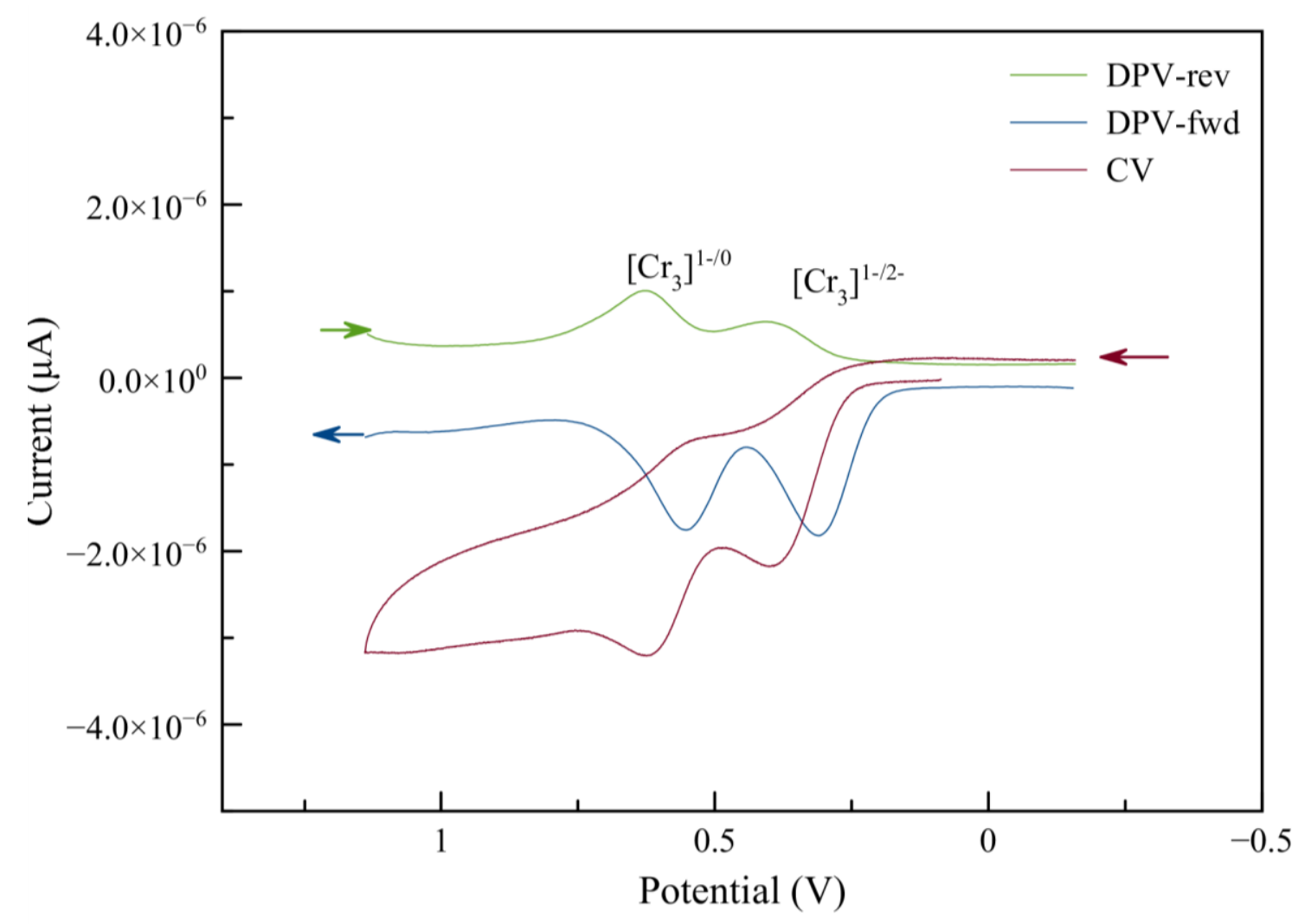

Figure 50. CV (red) and DPV (forward, blue; reverse, green) of $\mathbf{1 8 .}$

\subsubsection{Absorption Spectra}

Absorption spectra of $\mathbf{1 7}$ and $\mathbf{1 8}$ shows two broad bands around $18700 \mathrm{~cm}^{-1}\left(v_{1}\right)$ and $24800 \mathrm{~cm}^{-1}\left(\mathrm{v}_{2}\right)$, similar to previously studied trinuclear $\mathrm{Cr}^{\mathrm{III}}$ pyrazolate-formate mixed-ligand complexes. These correspond to ${ }^{4} \mathrm{~A}_{2 \mathrm{~g}}-{ }^{4} \mathrm{~T}_{2 \mathrm{~g}}(\mathrm{~F})$ and ${ }^{4} \mathrm{~A}_{2 \mathrm{~g}}-{ }^{4} \mathrm{~T}_{1 \mathrm{~g}}(\mathrm{~F})$ transitions, respectively. Shifts to higher energy on both bands are observed in the allpyrazolate complexes compared to the mixed-ligand complexes. An intense broad band corresponding to $\mathrm{Ph}_{4} \mathrm{P}^{+}$overlaps with $\mathrm{v}_{2}$. For pyrazolate complexes, ${ }^{4} \mathrm{~A}_{2 \mathrm{~g}}-{ }^{4} \mathrm{~T}_{2 \mathrm{~g}}(\mathrm{~F})$ transition is observed at $18690 \mathrm{~cm}^{-1}$ (17) and $18870 \mathrm{~cm}^{-1}$ (18). Energy shifts can be attributed to the terminal ligand substitution. 


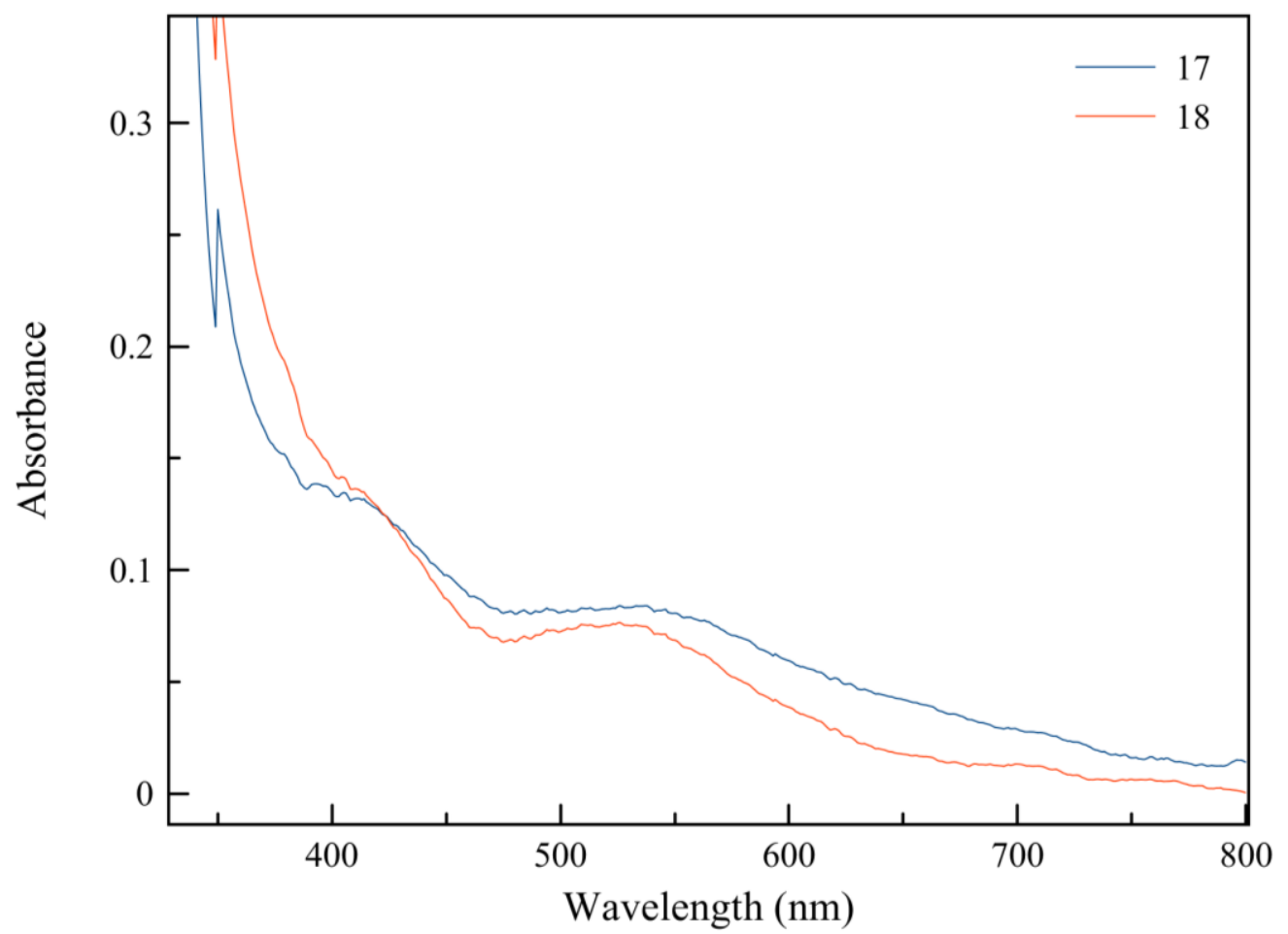

Figure 51. UV-VIS spectra for $\mathbf{1 7}$ and $\mathbf{1 8}$ in DCM.

\subsection{Conclusions}

The use of non-hydrolysable and high boiling point solvent yielded an allpyrazolate complex with formula $\left(\mathrm{Ph}_{4} \mathrm{P}\right)_{2}\left[\mathrm{Cr}_{3}\left(\mu_{3}-\mathrm{O}\right)(\mu-4-\mathrm{Cl}-\mathrm{pz})_{6} \mathrm{Cl}_{3}\right] \quad$ (17) and $\left(\mathrm{Ph}_{4} \mathrm{P}\right)_{2}\left[\mathrm{Cr}_{3}\left(\mu_{3}-\mathrm{O}\right)(\mu-4-\mathrm{Cl}-\mathrm{pz})_{6} \mathrm{Br}_{3}\right]$ (18). Reversible oxidation processes were observed for both complexes, where the potential depends on the identity of the terminal ligand. Oxidation potential is reduced from the $\mathrm{Cl}$ (17) substituted complex to the $\mathrm{Br}(\mathbf{1 8})$ substituted complex. Second quasi-reversible oxidation process is observed for 18. These systems are the first example of electrochemically amendable trinuclear pyrazolate complex with a $\left\{\mathrm{Cr}_{3} \mathrm{O}\right\}$ core. 


\subsection{Experimental section}

\subsubsection{Materials}

Chromium nitrate nonahydrate, 4-Cl-pyrazole, $\mathrm{Ph}_{4} \mathrm{PCl}$ and butyronitrile solvent were purchased from Fisher Scientific.

\subsubsection{Instrumentation}

Refer to section 2.4 .2 for instrumentation details.

\subsubsection{Synthesis}

\subsubsection{Synthesis of $\left(\mathrm{Ph}_{4} \mathrm{P}\right)_{2}\left[\mathrm{Cr}_{3}\left(\mu_{3}-\mathrm{O}\right)(\mu-4-\mathrm{Cl}-\mathrm{pz})_{6} \mathrm{Cl}_{3}\right](17)$}

A $10 \mathrm{~mL}$ round bottom flask was charged with $235.8 \mathrm{mg}(0.590 \mathrm{mmol})$ of $\mathrm{Cr}\left(\mathrm{NO}_{3}\right)_{3} \cdot 9 \mathrm{H}_{2} \mathrm{O}, 181.6 \mathrm{mg}(1.780 \mathrm{mmol})$ of $4-\mathrm{Cl}-\mathrm{pzH}$ and $205.5 \mu \mathrm{L}(1.474 \mathrm{mmol})$ of $\mathrm{Et}_{3} \mathrm{~N}$. Reaction mixture was heated to $100^{\circ} \mathrm{C}$ for 1 hour, until color changed to pink was observed. To the resulting solution, $443.6 \mathrm{mg}(1.164 \mathrm{mmol})$ of $\mathrm{Ph}_{4} \mathrm{PCl}$ was added and heated for 30 minutes. Pink solution was recovered after filtration and solvent was removed under reduced pressure. Reaction mixture was washed with ethanol followed by $\mathrm{Et}_{2} \mathrm{O}$. X-Ray suitable crystals were obtained from $\mathrm{MeOH}$ slow evaporation or $\mathrm{DCM} / \mathrm{Et}_{2} \mathrm{O}$ vapor diffusion. 


\subsubsection{Synthesis of $\left(\mathrm{Ph}_{4} \mathrm{P}\right)_{2}\left[\mathrm{Cr}_{3}\left(\mu_{3}-\mathrm{O}\right)(\mu-4-\mathrm{Cl}-\mathrm{pz})_{6} \mathrm{Br}_{3}\right](18)$}

A $10 \mathrm{~mL}$ round bottom flask was charged with $201.2 \mathrm{mg}(0.503 \mathrm{mmol})$ of $\mathrm{Cr}\left(\mathrm{NO}_{3}\right)_{3} \cdot 9 \mathrm{H}_{2} \mathrm{O}, 154.3 \mathrm{mg}(1.513 \mathrm{mmol})$ of $4-\mathrm{Cl}-\mathrm{pzH}$ and $175.5 \mu \mathrm{L}(1.257 \mathrm{mmol})$ of $\mathrm{Et}_{3} \mathrm{~N}$. Reaction mixture was heated to $100^{\circ} \mathrm{C}$ for 1 hour, until color changed to pink was observed. To the resulting solution, $420.9 \mathrm{mg}(1.003 \mathrm{mmol})$ of $\mathrm{Ph}_{4} \mathrm{PBr}$ was added and heated for 30 minutes. Pink solution was recovered after filtration and solvent was

removed under reduced pressure. Reaction mixture was washed with ethanol followed by $\mathrm{Et}_{2} \mathrm{O}$. X-Ray suitable crystals were obtained $\mathrm{DCM} / \mathrm{Et}_{2} \mathrm{O}$ vapor diffusion.

\subsubsection{Crystallographic data}

Refer to section 2.4 .2 for structure refinement details. 
Table 25. Structure refinement parameters of $\mathbf{1 7}$ and $\mathbf{1 8 .}$

\begin{tabular}{|c|c|c|c|c|}
\hline \multirow{2}{*}{$\frac{\text { Compound }}{\text { Temperature/K }}$} & \multicolumn{2}{|c|}{ (17) } & \multicolumn{2}{|c|}{ (18) } \\
\hline & 293 & 100.15 & 296.41 & 150.15 \\
\hline Empirical formula & $\mathrm{C}_{66} \mathrm{H}_{52} \mathrm{Cl}_{9} \mathrm{Cr}_{3} \mathrm{~N}_{12} \mathrm{OP}_{2}$ & $\mathrm{C}_{67} \mathrm{H}_{54} \mathrm{Cl}_{11} \mathrm{Cr}_{3} \mathrm{~N}_{12} \mathrm{OP}_{2}$ & $\mathrm{C}_{67} \mathrm{H}_{54} \mathrm{Br}_{3} \mathrm{Cl}_{8} \mathrm{Cr}_{3} \mathrm{~N}_{12} \mathrm{OP}$ & ${ }_{2} \mathrm{C}_{67} \mathrm{H}_{54} \mathrm{Br}_{3} \mathrm{Cl}_{8} \mathrm{Cr}_{3} \mathrm{~N}_{11} \mathrm{O}_{2} \mathrm{P}_{2}$ \\
\hline Formula weight & 1566.18 & 1651.11 & 1784.49 & 1786.48 \\
\hline Crystal system & orthorhombic & orthorhombic & orthorhombic & orthorhombic \\
\hline Space group & Pbcn & $\operatorname{Pna}_{1}$ & Pbcn & $\operatorname{Pna}_{1}$ \\
\hline $\mathbf{a} / \AA$ & $16.926(2)$ & $23.746(5)$ & $17.1340(7)$ & $24.040(1)$ \\
\hline $\mathbf{b} / \AA$ & $17.664(2)$ & $23.746(5)$ & $17.9303(7)$ & $17.8794(8)$ \\
\hline $\mathbf{c} / \AA ̊$ & $24.054(3)$ & $16.981(4)$ & $24.288(1)$ & $16.9017(7)$ \\
\hline$\alpha /{ }^{\circ}$ & 90 & 90 & 90 & 90 \\
\hline$\beta /{ }^{\circ}$ & 90 & 90 & 90 & 90 \\
\hline$\gamma /{ }^{\circ}$ & 90 & 90 & 90 & 90 \\
\hline Volume $/ \AA^{3}$ & $7191(1)$ & $7073(3)$ & $7461.6(5)$ & $7264.7(5)$ \\
\hline $\mathbf{Z}$ & 4 & 4 & 4 & 4 \\
\hline$\rho_{\text {calc }} g / \mathbf{c m}^{3}$ & 1.447 & 1.551 & 1.589 & 1.633 \\
\hline$\mu / \mathbf{m m}^{-1}$ & 0.874 & 0.967 & 2.415 & 2.482 \\
\hline$F(000)$ & 3180.0 & 3348.0 & 3564.0 & 3568.0 \\
\hline Crystal size $/ \mathbf{m m}^{3}$ & $0.198 \times 0.078 \times 0.052$ & $0.282 \times 0.077 \times 0.075$ & $0.24 \times 0.113 \times 0.112$ & $0.25 \times 0.072 \times 0.063$ \\
\hline $2 \Theta$ range for data collection/ & 5.724 to 49.626 & 5.776 to 49.606 & 5.82 to 52.964 & 5.894 to 52.938 \\
\hline Reflections collected & 136294 & 96314 & 162357 & 160232 \\
\hline Data/restraints/parameters & $6198 / 21 / 486$ & $12054 / 1 / 866$ & $7708 / 0 / 445$ & $14916 / 1 / 866$ \\
\hline Goodness-of-fit on $F^{2}$ & 1.083 & 1.058 & 1.200 & 1.046 \\
\hline$R_{1}, w_{2}[I>=2 \sigma(I)]$ & $0.0678,0.1422$ & $0.0713,0.1491$ & $0.0804,0.1573$ & $0.0472,0.0947$ \\
\hline $\mathbf{R}_{1}, \mathbf{w R}_{2}$ [all data] & $0.1173,0.1626$ & $0.1207,0.1685$ & $0.1185,0.1699$ & $0.0707,0.1035$ \\
\hline Flack parameter & & $0.51(6)$ & & $0.403(9)$ \\
\hline
\end{tabular}




\section{Chapter 5: Iron pyrazolate complexes with $\mathrm{Fe}_{3}\left(\mu_{3}-\mathrm{O}\right)$ cores}

\section{Pyrazolate-supported $\mathrm{Fe}_{3}\left(\mu_{3}-\mathrm{O}\right)$ cores}

\subsection{Introduction}

Spin-crossover (SCO) materials are good candidates for sensing and memory storage devices. ${ }^{121}$ External stimulus can cause a SCO transition, where the material undergoes a change in physical and chemical properties. The reorganization of electron causes a change in net magnetization, color, and, bond distances. Ligand orientation and orbital effects on transition metal complexes had been described by Crystal Field Theory. ${ }^{122}$ The SCO properties depend greatly on the ligand field surrounding the metal center. Studies of high nuclearity $\mathrm{Fe}(\mathrm{II})$ complexes show a thermally induced paramagnetic-diamagnetic transition from $\mathrm{S}=2$ to $\mathrm{S}=0 .{ }^{123,124}$ In addition, multiple examples of $\mathrm{Fe}(\mathrm{II})$ complexes show reversible $\mathrm{SCO}$ processes upon photo-excitation using UV-Vis or X-Ray radiation. ${ }^{125,126}$ Spin transition from high-spin (HS) to low-spin (LS) have been observed at the molecular lever for $\left[\mathrm{Mn}^{\mathrm{III}}(\mathrm{taa})\right]\left[\mathrm{H}_{3} \operatorname{taa}=\operatorname{tris}(1-(2\right.$-azolyl)2-azabuten-4-yl)amine] after applying a magnetic field. ${ }^{127}$ Several other examples involving mononuclear complexes have been reported. ${ }^{128}$

The first example of a redox induced spin transition cascade was reported using trinuclear complex with formula $\left[\mathrm{Fe}_{3}\left(\mu_{3}-\mathrm{O}\right)\left(4-\mathrm{NO}_{2}-\mathrm{pz}\right)_{6}(\mathrm{NCS})_{3}\right]^{2-}$. The cascade of HS to LS electron reorganization arises from the one-electron reduction of the all-ferric thiocyanate complex to its mixed-valent $\left[\mathrm{Fe}_{3}\right]^{3-}$ trianionic analogue. This was supported ${ }^{57} \mathrm{Fe}-\mathrm{Mössbauer,}{ }^{1} \mathrm{H}-\mathrm{NMR}$, and UV-Vis-NIR spectroscopy. 


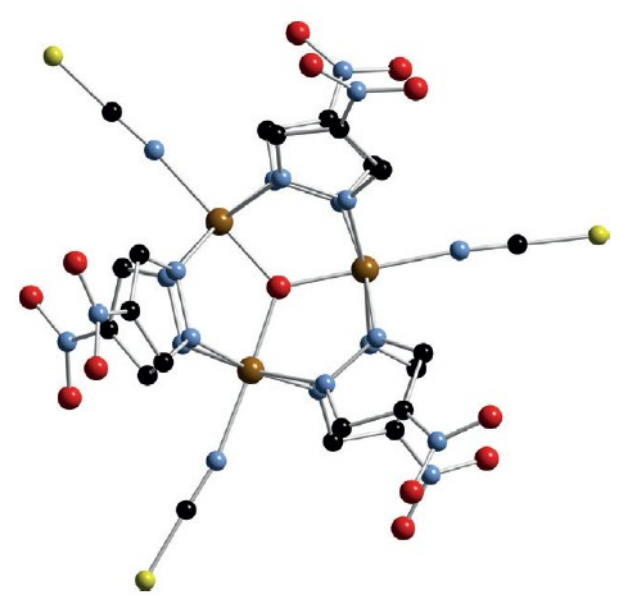

Figure 52. Ball-and-stick representation of $\left[\mathrm{Fe}_{3}\left(\mu_{3}-\mathrm{O}\right)\left(4-\mathrm{NO}_{2}-\mathrm{pz}\right)_{6}(\mathrm{SCN})_{3}\right]^{2-}$.

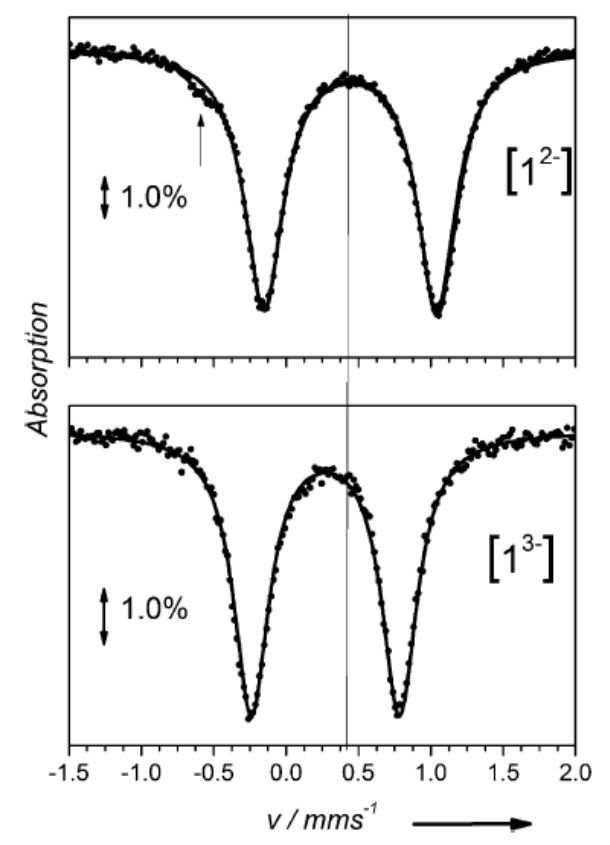

Figure 53. ${ }^{57} \mathrm{Fe}-\mathrm{Mössbauer}$ spectra of the all ferric of $\left[\mathrm{Fe}_{3}\left(\mu_{3}-\mathrm{O}\right)\left(4-\mathrm{NO}_{2}-\mathrm{pz}\right)_{6}(\mathrm{SCN})_{3}\right]^{2-}$ (top) and the one electron reduced of $\left[\mathrm{Fe}_{3}\left(\mu_{3}-\mathrm{O}\right)\left(4-\mathrm{NO}_{2}-\mathrm{pz}\right)_{6}(\mathrm{SCN})_{3}\right]^{3-}$.

Here we present the synthesis of complexes with formula $\left[\mathrm{Fe}_{3}\left(\mu_{3}-\mathrm{O}\right)\left(4-\mathrm{NO}_{2}\right.\right.$ pz $\left.)_{6} \mathrm{~L}_{3}\right]^{2-}\left(\mathrm{L}=\mathrm{NCO}^{-}, \mathrm{N}_{3}^{-}\right)$. Iron timers with such ligands are expected to have similar properties as the reported $\left[\mathrm{Fe}_{3}\left(\mu_{3}-\mathrm{O}\right)\left(\mu-4-\mathrm{NO}_{2}-\mathrm{pz}\right)_{6}(\mathrm{NCS})_{3}\right]^{2-}$ since $\mathrm{NCO}^{-}$and $\mathrm{N}_{3}^{-}$ligands have similar electron withdrawing properties as $\mathrm{SCN}^{-}$. 


\subsection{Results and discussion}

\subsubsection{Synthesis and crystal structure description}

Reaction of $\left[\mathrm{Fe}_{3}\left(\mu_{3}-\mathrm{O}\right)\left(4-\mathrm{NO}_{2}-\mathrm{pz}\right)_{6} \mathrm{Cl}_{3}\right]^{2-}$ with excess of $\mathrm{NaNCO}$ and $\mathrm{NaN}_{3}$ yielded two new complexes with formula $\left[\mathrm{Fe}_{3}\left(\mu_{3}-\mathrm{O}\right)\left(4-\mathrm{NO}_{2}-\mathrm{pz}\right)_{6}(\mathrm{NCO})_{3}\right]$ (19) and $\left[\mathrm{Fe}_{3}\left(\mu_{3}-\mathrm{O}\right)\left(4-\mathrm{NO}_{2}-\mathrm{pz}\right)_{6}\left(\mathrm{~N}_{3}\right)_{3}\right](\mathbf{2 0})$. Structures of 19 and $\mathbf{2 0}$ contain three octahedral $\mathrm{Fe}^{\mathrm{III}}$

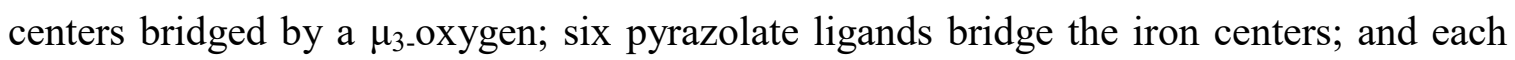
iron center is bonded to a terminal ligand. The $\mathrm{Fe}-\mathrm{O}$ bonds and $\mathrm{Fe}{ }^{\cdots} \mathrm{Fe}$ distances are in agreement with an all-ferric trinuclear $\mathrm{Fe}_{3}^{\mathrm{III}}{ }_{3}$ complex. Linear geometry of the terminal $\mathrm{NCO}^{-}$ligand is consistent with N-bonded NCO.

Complex 19 and 20 crystallized with a whole molecule in the asymmetric unit. Complex 19 and 20 crystallized in a monoclinic $P 2_{l} / n$ and $P 2_{l} / C$ space group, respectively. Selected bond lengths and crystallographic refinement details are summarized in Table 26 and Table 28, respectively.

Table 26. Selected bond length for $\mathbf{1 9}$ and $\mathbf{2 0}$ in $\AA$.

\begin{tabular}{ccc} 
& \multicolumn{3}{c}{ Compound } \\
\cline { 2 - 3 } Bond & $\mathbf{1 9}$ & $\mathbf{2 0}$ \\
\hline $\mathrm{Fe} \cdots \mathrm{Fe}$ & $3.266-3.271$ & $3.239-3.288$ \\
$\mathrm{Fe}-\mathrm{O}$ & $1.874(3)-1.896(3)$ & $1.858(3)-1.868(3)$ \\
$\mathrm{Fe}-\mathrm{N}_{\text {terminal }}$ & $1.947-1.966$ & $1.913-2.081$
\end{tabular}




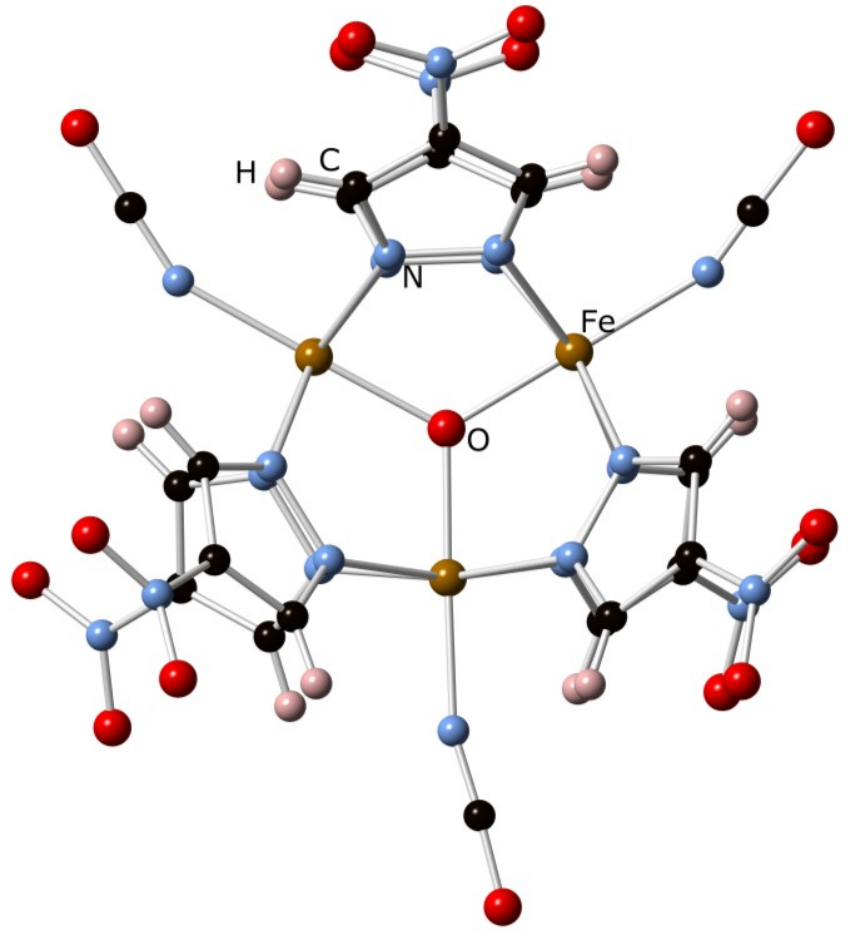

Figure 54. Ball and stick representation of $\left[\mathrm{Fe}_{3}\left(\mu_{3}-\mathrm{O}\right)\left(4-\mathrm{NO}_{2}-\mathrm{pz}\right)_{6}(\mathrm{NCO})_{3}\right]^{2-}(19)$. $\mathrm{TBA}^{+}$ counter ion and hydrogen atoms are omitted for clarity.

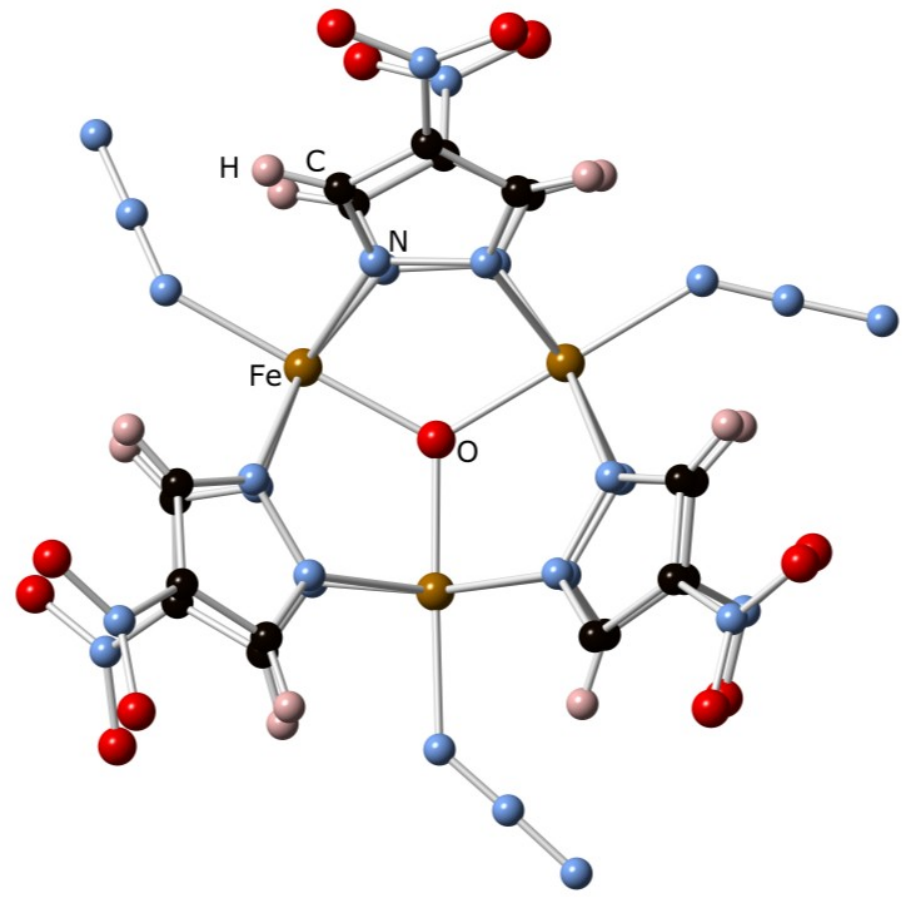

Figure 55. Ball and stick representation of $\left[\mathrm{Fe}_{3}\left(\mu_{3}-\mathrm{O}\right)\left(4-\mathrm{NO}_{2}-\mathrm{pz}\right)_{6}\left(\mathrm{~N}_{3}\right)_{3}\right]^{2-}(\mathbf{2 0}) . \mathrm{Ph}_{4} \mathrm{P}^{+}$ counter ions and hydrogen atoms are omitted for clarity. 


\subsubsection{Electrochemistry}

Cyclic voltammogram (CV) and differential pulse voltammogram (PDV) were collected for complexes 19 and $\mathbf{2 0}$. Owing to the similarities on electron withdrawing capacity of $\mathrm{NCO}$ and $\mathrm{N}_{3}$, compared to $\mathrm{NCS}$, we expect these complexes to show similar electrochemical behavior.

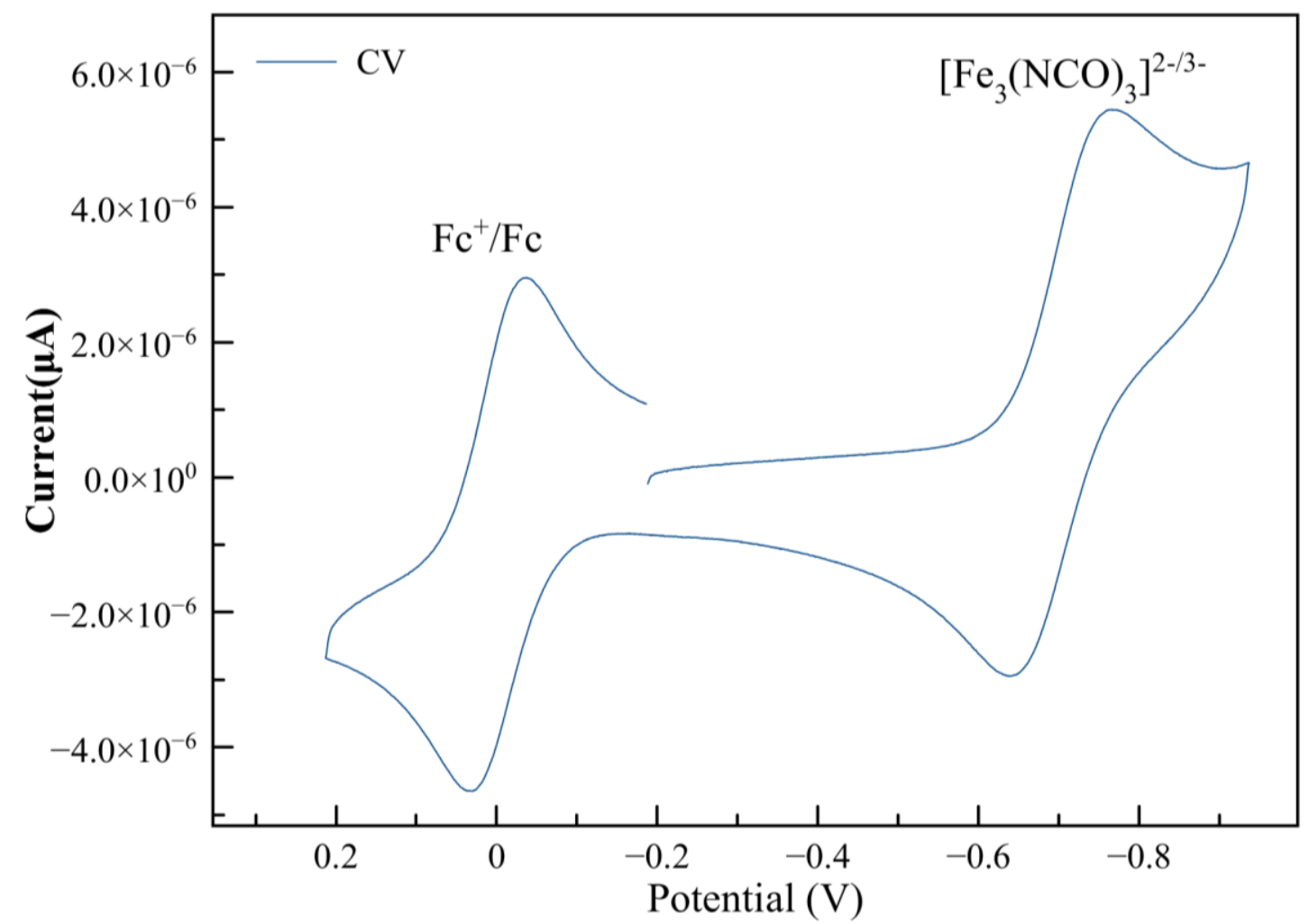

Figure 56. CV of 19 vs. $\mathrm{Fc}^{+} / \mathrm{Fc}$. of $\left[\mathrm{Fe}_{3}\left(\mu_{3}-\mathrm{O}\right)\left(4-\mathrm{NO}_{2}-\mathrm{pz}\right)_{6}(\mathrm{NCO})_{3}\right]^{2-/ 3-}\left(\mathrm{E}_{1 / 2}=-0.70 \mathrm{~V}\right)$

The CV of $(\mathrm{TBA})_{2}\left[\mathrm{Fe}_{3}\left(\mu_{3}-\mathrm{O}\right)\left(4-\mathrm{NO}_{2}-\mathrm{pz}\right)_{6}(\mathrm{NCO})_{3}\right](19)$ and $\left(\mathrm{Ph}_{4} \mathrm{P}\right)_{2}\left[\mathrm{Fe}_{3}\left(\mu_{3}-\mathrm{O}\right)(4-\right.$ $\left.\left.\mathrm{NO}_{2}-\mathrm{pz}\right)_{6}\left(\mathrm{~N}_{3}\right)_{3}\right](\mathbf{2 0})$ are illustrated in Figure 56 and Figure 57, respectively. Complex 19 shows a one-electron reversible reduction process for a $\left[\mathrm{Fe}_{3}(\mathrm{NCO})_{3}\right]^{2-/ 3-}$ species at $-0.70 \mathrm{~V}$. Complex 20 shows a one-electron reversible reduction process at $-0.70 \mathrm{~V}$ 
corresponding to the reduction pair $\left[\mathrm{Fe}_{3}\left(\mathrm{~N}_{3}\right)_{3}\right]^{2-/ 3-}$. Expected reversible reduction processes were observed for both complexes at more cathodic potential, $-0.70 \mathrm{~V}$, than the thiocyanate complex $(-0.36 \mathrm{~V})$.

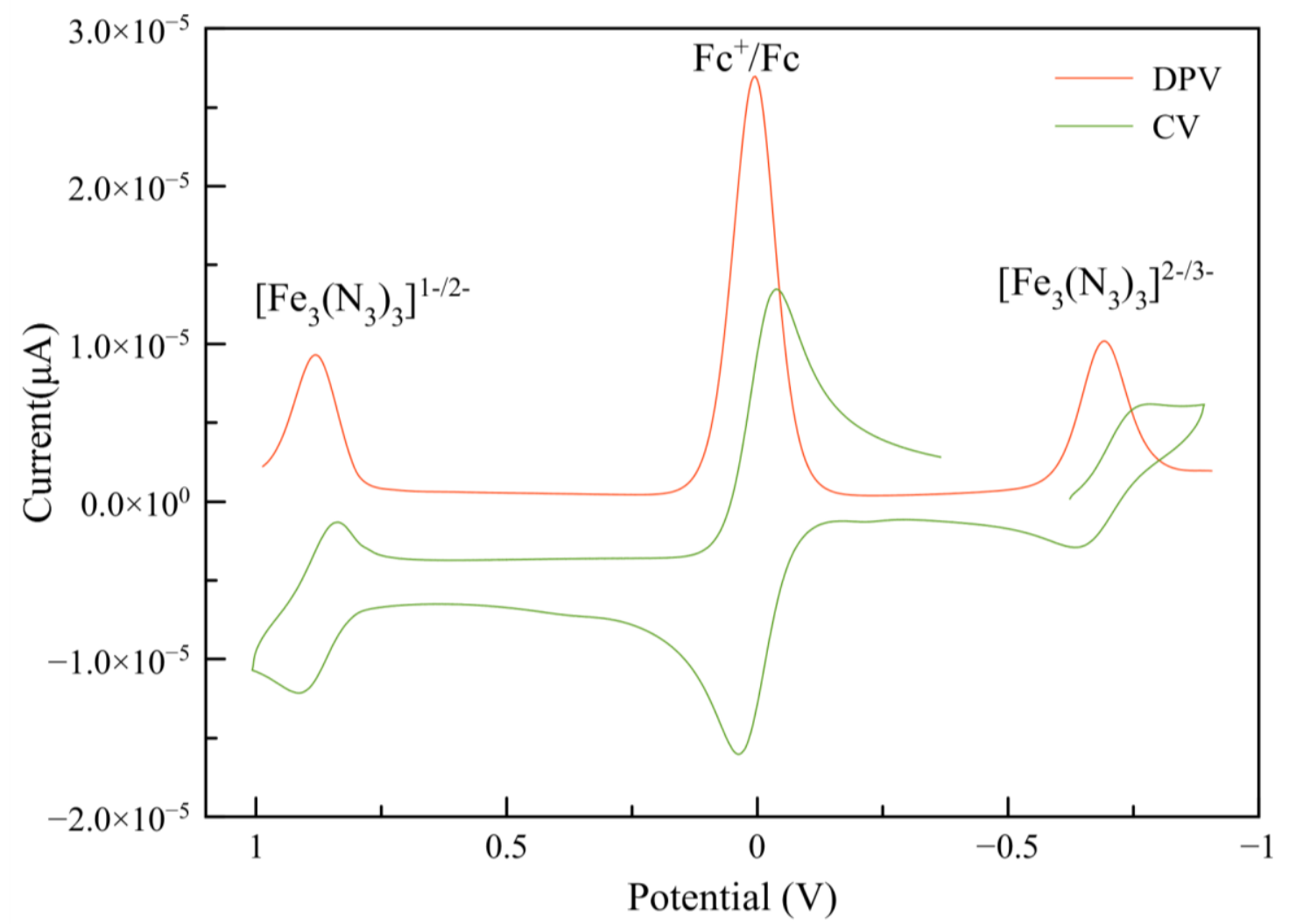

Figure 57. DPV (red) and CV (green) of $\mathbf{2 0} v s . \mathrm{Fc}^{+} / \mathrm{Fc}$. of $\left[\mathrm{Fe}_{3}\left(\mu_{3}-\mathrm{O}\right)\left(4-\mathrm{NO}_{2}-\mathrm{pz}\right)_{6}\left(\mathrm{~N}_{3}\right)_{3}\right]^{1-}$ ${ }^{12-}\left(\mathrm{E}_{1 / 2}=0.87 \mathrm{~V}\right)$ and of $\left[\mathrm{Fe}_{3}\left(\mu_{3}-\mathrm{O}\right)\left(4-\mathrm{NO}_{2}-\mathrm{pz}\right)_{6}\left(\mathrm{~N}_{3}\right)_{3}\right]^{2-/ 3-}\left(\mathrm{E}_{1 / 2}=-0.70 \mathrm{~V}\right)$.

Moreover, an unprecedented reversible oxidation process is observed for $\mathbf{2 0}$ at $0.87 \mathrm{~V}$ for the oxidation pair $\left[\mathrm{Fe}_{3}\left(\mathrm{~N}_{3}\right)_{3}\right]^{1-2-}$. Simultaneous oxidation and reduction processes have not been previously observed and it is uncommon for trinuclear pyrazolate complexes. Compound 20 oxidizes to $\left[\mathrm{Fe}_{3}\left(\mu_{3}-\mathrm{O}\right)\left(4-\mathrm{NO}_{2}-\mathrm{pz}\right)_{6}\left(\mathrm{~N}_{3}\right)_{3}\right]^{-}$, a mixedvalent, formally $\mathrm{Fe}^{3+}{ }_{2} / \mathrm{Fe}^{4+}$ species. 


\subsubsection{UV-Vis-NIR}

All ferric $\left[\mathrm{Fe}_{3}\left(\mu_{3}-\mathrm{O}\right)\left(4-\mathrm{NO}_{2}-\mathrm{pz}\right)_{6}(\mathrm{NCO})_{3}\right]^{-2}$ (19) was chemically reduced using tetrabutylammonium tetrahydroborate $\left(\mathrm{TBABH}_{4}\right)$. Solution color change was indicative of reaction. After reaction was filtered, a black solid and orange solution as obtained. The UV-Vis-NIR of product did not show IVCT band in the NIR region of spectra or any difference to the UV-Vis of the all-ferric starting material, indicative of a failed reaction.

All ferric $\left[\mathrm{Fe}_{3}\left(\mu_{3}-\mathrm{O}\right)\left(4-\mathrm{NO}_{2}-\mathrm{pz}\right)_{6}\left(\mathrm{~N}_{3}\right)_{3}\right]^{-2}$ (20) was chemically reduced using $\mathrm{TBABH}_{4}$. The UV-Vis-NIR of 20 (Figure 58) shows a blue shift on CT bands after reduction, consistent with Metal-to-Ligand CT bands. An IVCT band at $9081 \mathrm{~cm}^{-1}$ in the NIR region of the spectrum (inset) is characteristic of a partially delocalized mixed-valent species in solution. Band broadness suggests charge delocalization upon reduction, having all iron centers with the same oxidation state $\left(\mathrm{Fe}^{2.66+}\right)$. The empirical parameter, $\Gamma$, 0.30 was calculated for the IVCT band, typical of a weakly coupled Class II mixed-valent species..$^{\dagger}$

\footnotetext{
${ }^{\dagger}$ Parameter is calculated following Hush theory from: $\Gamma=1-\frac{\Delta v}{\Delta v_{1 / 2}^{0}}$

Class I, no interaction, $\Gamma=0$; Class II, weakly coupled, $0<\Gamma<0.5$; Class III, strongly delocalized, $\Gamma>0.5$
} 


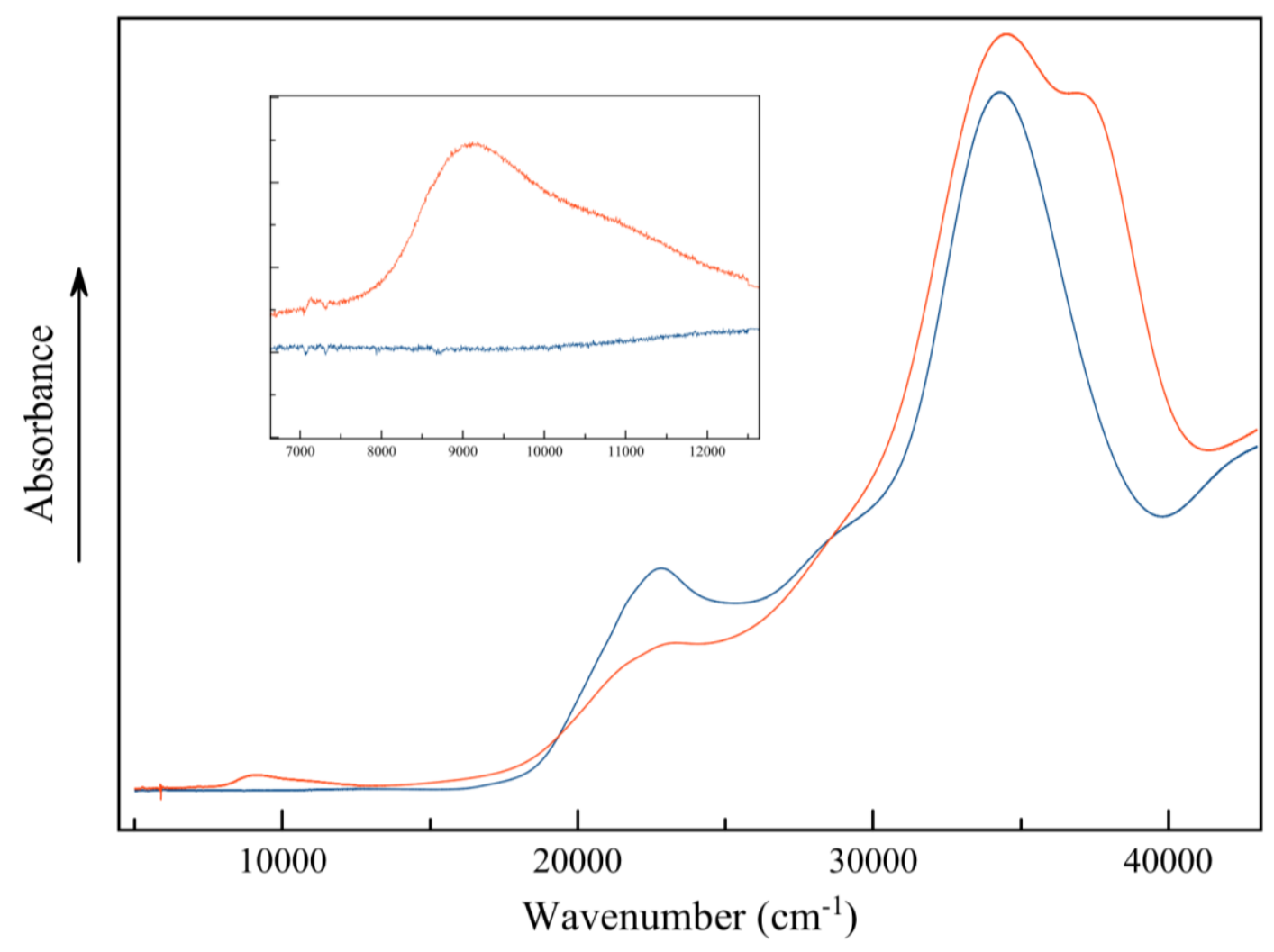

Figure 58. UV-Vis- NIR of $\left[\mathrm{Fe}_{3}\left(\mu_{3}-\mathrm{O}\right)\left(4-\mathrm{NO}_{2}-\mathrm{pz}\right)_{6}\left(\mathrm{~N}_{3}\right)_{3}\right]^{-2}$ (red) and product of reduction with $\mathrm{TBABH}_{4}$ (blue).

Chemical oxidization using ammonium cerium(V) nitrate was performed and the UV-Vis-NIR spectra was recorded (Figure 59). The all ferric (TBA) $2\left[\mathrm{Fe}_{3}\left(\mu_{3}-\mathrm{O}\right)\left(4-\mathrm{NO}_{2}{ }^{-}\right.\right.$ pz $\left.)_{6}\left(\mathrm{~N}_{3}\right)_{3}\right]$ shows two charge transfer band peaks at $22815 \mathrm{~cm}^{-1}$ and $34325 \mathrm{~cm}^{-1}$. After chemical oxidation, the band at $22815 \mathrm{~cm}^{-1}$ was shifted under the broad band at 36990 $\mathrm{cm}^{-1}$. Expected IVCT band in the NIR was not observed, probably due to the presence or a charge localized system or incomplete oxidation. 


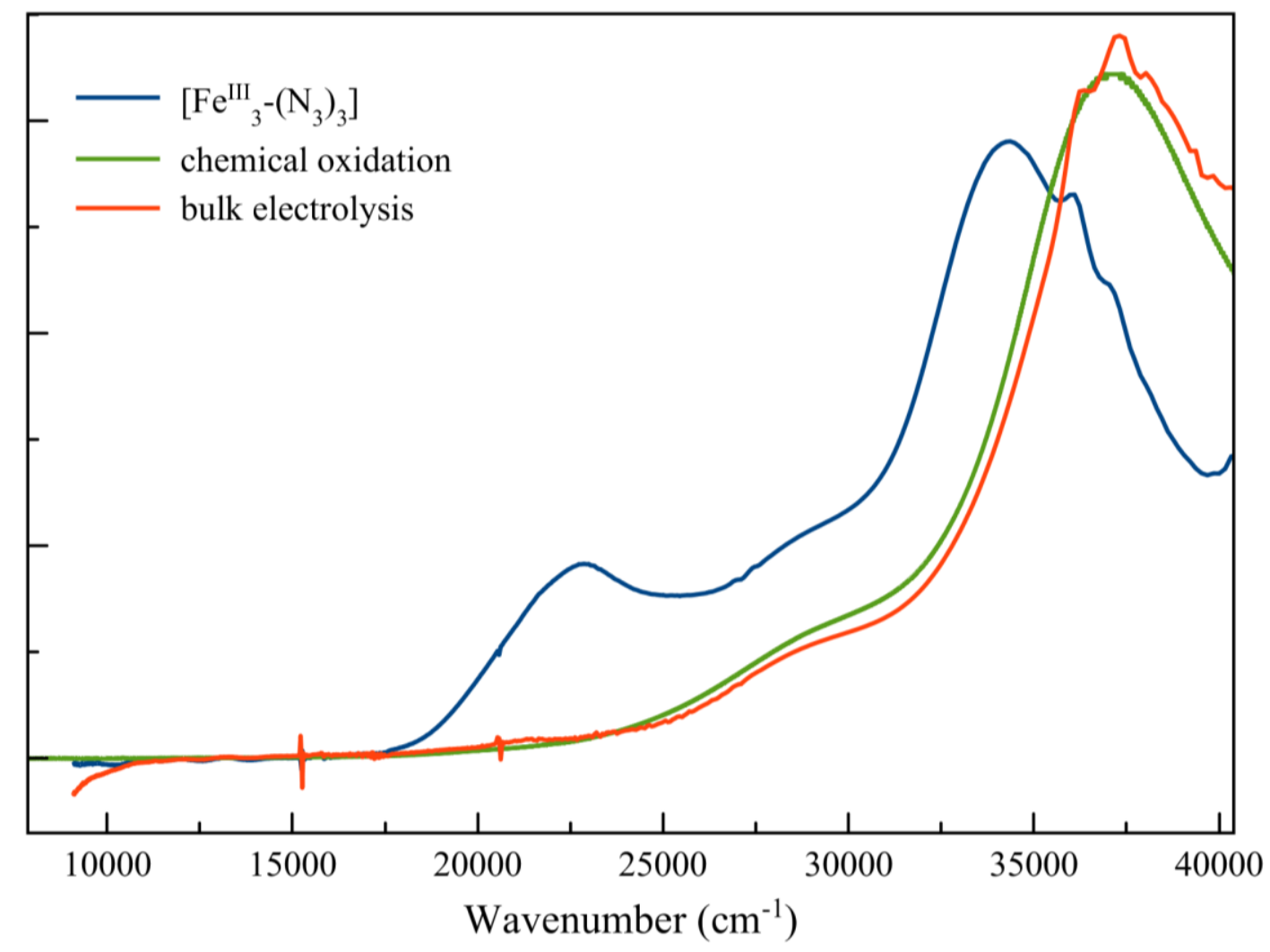

Figure 59. UV-Vis- NIR of $(\mathrm{TBA})_{2}\left[\mathrm{Fe}_{3}\left(\mu_{3}-\mathrm{O}\right)\left(4-\mathrm{NO}_{2}-\mathrm{pz}\right)_{6}\left(\mathrm{~N}_{3}\right)_{3}\right]$ (blue), product from oxidation with ammonium cerium(V) nitrate (green) and bulk electrolysis (orange).

Bulk electrolysis was performed to complex $\mathbf{2 0}$ to electrochemically oxidize the material and study the spectroscopic properties of the product. Electrochemical measurements are coupled to an in situ spectroscopic measurements in order to probe intermediates of reaction and/or products. ${ }^{129}$ Spectra was obtained from a $0.1 \mathrm{M} \mathrm{TBAPF}_{6}$ solution of 20 in DCM, where a $1.25 \mathrm{~V}$ potential was applied for 4 hours achieving the bulk electrolysis of the sample (glassy carbon working electrode, $\mathrm{Ag} / \mathrm{AgCl}$ reference electrode, graphite auxiliary electrode). Spectra after bulk electrolysis is consistent with the spectra obtained after chemical oxidation (Figure 59). 


\subsubsection{Infrared spectrum}

Characteristic stretch for $\mathrm{N}_{3}^{-}$ligand is obtained from infrared spectroscopy. The mixed-valent complex obtained from chemical reduction or oxidation can be characterized as localized, partially localized or delocalized within the three metal centers. Double stretch in the IR spectrum after chemical oxidation (Figure 60) might be indicative of charge localization in the IR timescale. Coinciding peak with starting material at $2059 \mathrm{~cm}^{-1}$ might be indicative of incomplete oxidation. Decrease in stretch intensity can also suggest terminal ligand substitution with nitrate. Chemical reduction of 20 causes $\mathrm{N}_{3}{ }^{-}$stretch to shift to lower energy, pointing to a bond weakening caused by additional $\pi$ back-bonding from the metal to the terminal ligand.

Table 27. IR stretch frequency $\left(\mathrm{cm}^{-1}\right)$ of coordinated azide ligands.

\begin{tabular}{cc} 
Species & $v\left(\mathrm{~cm}^{-1}\right)$ \\
\hline $\mathrm{Fe}^{\mathrm{III}}{ }_{2} \mathrm{Fe}^{\mathrm{IV}}$ & 2059 and 2134 \\
$\mathrm{Fe}^{\mathrm{III}}$ & 2059 \\
$\mathrm{Fe}^{\mathrm{III}}{ }_{2} \mathrm{Fe}^{\mathrm{II}}$ & 2042
\end{tabular}

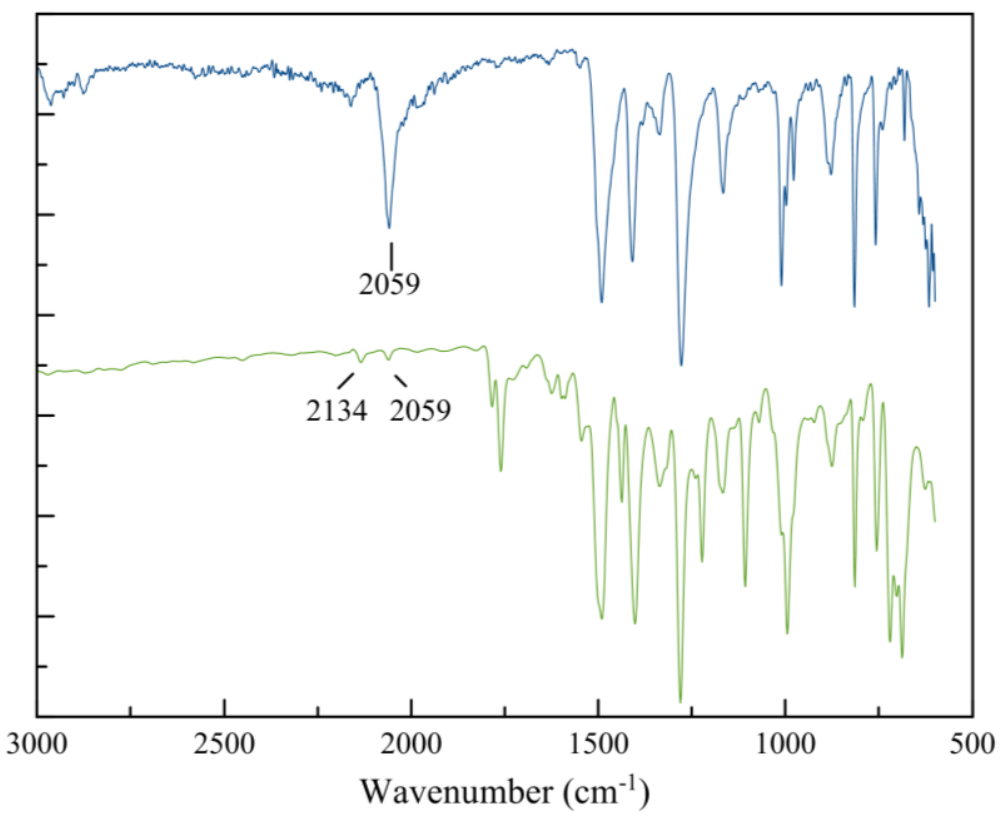

Figure 60. IR spectra of $\mathbf{2 0}$ (blue) and chemical oxidation of $\mathbf{2 0}$ (green). 


\subsubsection{Nuclear magnetic resonance}

Previous magnetic studies of trinuclear pyrazolate complexes have determined a paramagnetic ground state with $S=1 / 2 \cdot{ }^{33}$ Chemical reduction or oxidation of the trinuclear complex results in a new diamagnetic ground state $S=0$. Complex 20 (Figure 61), reduced, and oxidized product of $\mathbf{2 0}$ were characterized using ${ }^{1} \mathrm{H}$ NMR. Broad resonance at $32.09 \mathrm{ppm}$ corresponds to the paramagnetically shifted proton signal for the $\mathrm{H}^{3} / \mathrm{H}^{5}$ position of the pyrazole in 20. After chemical reduction, broad peak at $2.01 \mathrm{ppm}$ is observed while peak at 32.09 ppm disappears, consistent with a diamagnetic product. After chemical oxidation, shifted broad band at $30.7 \mathrm{ppm}$ and new signal at $8.62 \mathrm{ppm}$ are observed, two proton environments after oxidation suggest charge localization on the mixed-valent $\mathrm{Fe}^{\mathrm{III}}{ }_{2} \mathrm{Fe}^{\mathrm{IV}}$ system.

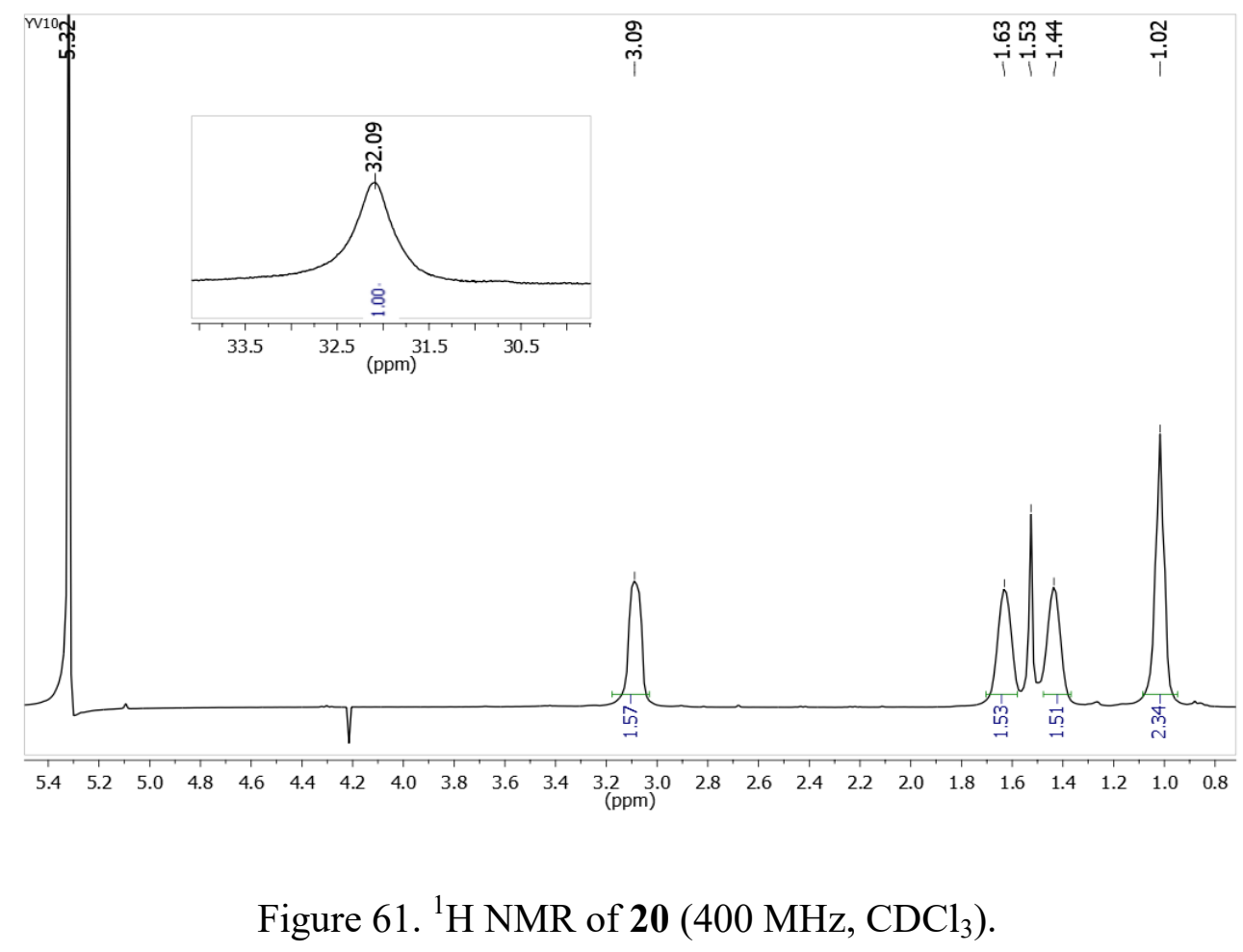




\subsection{6. ${ }^{57}$ Fe- Mössbauer}

Mössbauer spectra were collected from powdered samples of $\mathbf{2 0}$ and reduced product at $80 \mathrm{~K}$. Representative spectra are shown in Figure 62. Spectrum is similar to other $\left[\mathrm{Fe}_{3}\left(\mu_{3}-\mathrm{O}\right)\left(4-\mathrm{NO}_{2}-\mathrm{pz}\right)_{6} \mathrm{~L}_{3}\right]^{2-}\left(\mathrm{L}=\mathrm{Cl}^{-}, \mathrm{Br}^{-}, \mathrm{SCN}^{-}\right.$, py, 4-Me-py) complexes, characterized by quadrupole doublets. ${ }^{33-35}$ The spectra for $\mathbf{2 0}$ is highly characteristic of high-spin ferric ions, with an isomer shift, $\delta=0.45 \mathrm{mms}^{-1}$ and quadrupole splitting $\Delta \mathrm{E}_{\mathrm{Q}}=$ $1.05 \mathrm{mms}^{-1}$. After chemical reduction a doublet is also observed, suggesting delocalization of additional electron over the three iron centers. Both, the isomer shift $(\delta$ $\left.=0.40 \mathrm{mms}^{-1}\right)$ and quadrupole splitting $\left(\Delta \mathrm{E}_{\mathrm{Q}}=0.83 \mathrm{mms}^{-1}\right)$ are reduced after chemical reduction of 20, indicative of an electronic structural change after reduction. The -0.05 $\mathrm{mms}^{-1}$ decrease in isomer shift can suggest a high-to-low spin electronic reorganization as observed with the $\left[\mathrm{Fe}_{3}(\mathrm{SCN})_{3}\right]$ complex. ${ }^{34}$

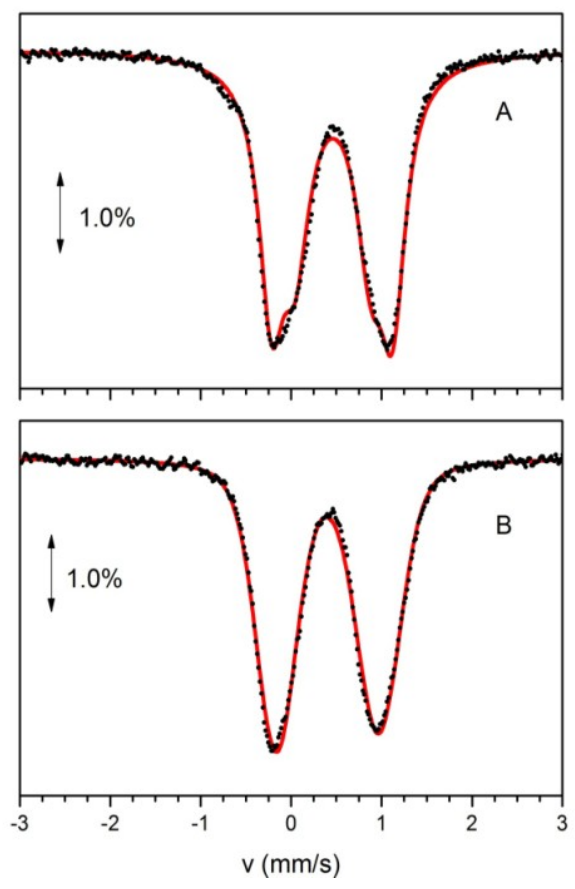

Figure 62. ${ }^{57} \mathrm{Fe}$ Mössbauer spectra of a powdered sample of 20 (A) and reduced product (B) at $80 \mathrm{~K}$. 


\subsection{Conclusions}

The all-ferric complexes $\left[\mathrm{Fe}_{3}\left(\mu_{3}-\mathrm{O}\right)\left(\mu-4-\mathrm{NO}_{2}-\mathrm{pz}\right)_{6} \mathrm{~L}_{3}\right]^{2-}\left(\mathrm{L}=\mathrm{NCO}^{-}, \mathrm{N}_{3}\right)$ were synthesized by substitution of terminal $\mathrm{Cl}^{-}$ligands of the parent compound $\left[\mathrm{Fe}_{3}\left(\mu_{3}-\mathrm{O}\right)\left(\mu-4-\mathrm{NO}_{2}-\right.\right.$ pz) $\left.{ }_{6} \mathrm{Cl}_{3}\right]^{2-}$ using $\mathrm{NaNCO}$ and $\mathrm{NaN}_{3}$. Expected reversible reduction processes were observed for both complexes at more cathodic potential, $-0.70 \mathrm{~V}$, than the thiocyanate complex $(-0.36 \mathrm{~V})$. Compound 20 shows a unique reversible oxidation process at $0.82 \mathrm{~V}$ (vs. $\left.\mathrm{Fc}^{+} / \mathrm{Fc}\right)$ to $\left[\mathrm{Fe}_{3}\left(\mu_{3}-\mathrm{O}\right)\left(\mu-4-\mathrm{NO}_{2}-\mathrm{pz}\right)_{6}\left(\mathrm{~N}_{3}\right)_{3}\right]^{-}$, a mixed-valent, formally $\mathrm{Fe}^{3+}{ }_{2} / \mathrm{Fe}^{4+}$ species. Chemical reduction of $\mathbf{1 9}$ was unsuccessful, whereas reduction of $\mathbf{2 0}$ shows distinct IVCT band in NIR region of spectra, indicative of mixed-valent specie. Mössbauer of the reduced product of $\mathbf{2 0}$ suggests a high-to-low spin electronic reorganization similar to the $\left[\mathrm{Fe}_{3}\left(\mu_{3}-\mathrm{O}\right)\left(\mu-4-\mathrm{NO}_{2}-\mathrm{pz}\right)_{6}(\mathrm{SCN})_{3}\right]$ complex. ${ }^{34}$ Two distinct signals in ${ }^{1} \mathrm{H}$ NMR and IR spectra after chemical oxidation of $\mathbf{2 0}$ suggest incomplete oxidation or charge localization in a mixed-valent $\mathrm{Fe}^{\mathrm{III}}{ }_{2} \mathrm{Fe}^{\mathrm{IV}}$ system. Attempts with excess oxidant have not shown differing results.

\subsection{Experimental section}

\subsubsection{Materials}

Reagent grade chemicals were purchased from Fisher scientific, Aldrich Chemical Co, Alfa Aesar or ACROS Organics. Pyrazole ligand ${ }^{130}$ and $\left[\mathrm{Fe}_{3}\left(\mu_{3}-\mathrm{O}\right)\left(4-\mathrm{NO}_{2}-\mathrm{pz}\right)_{6} \mathrm{Cl}_{3}\right]^{2-}$ complex $^{33}$ were synthesized from previously reported methods. Reactions were performed at room temperature.

\subsubsection{Instrumentation}

Refer to section 2.4.2 for instrumentation details. 


\subsubsection{Synthesis and characterization}

\subsubsection{Synthesis of $\left(\mathrm{TBA}_{2}\left[\mathrm{Fe}_{3}\left(\mu_{3}-\mathrm{O}\right)\left(4-\mathrm{NO}_{2}-\mathrm{pz}\right)_{6}(\mathrm{NCO})_{3}\right](19)\right.$}

A $30 \mathrm{~mL}$ vial was charged with $74 \mathrm{mg}(0.051 \mathrm{mmol})(\mathrm{TBA})_{2}\left[\mathrm{Fe}_{3}\left(\mu_{3}-\mathrm{O}\right)\left(4-\mathrm{NO}_{2}-\right.\right.$ pz) ${ }_{6} \mathrm{Cl}_{3}$ ], dissolved with $10 \mathrm{~mL}$ of DCM, followed by addition of $15.30 \mathrm{mg}(2.35 \mathrm{mmol})$ of $\mathrm{NaNCO}$. The reaction mixture was stirred for 48 hours. Unreacted $\mathrm{NaNCO}$ and $\mathrm{NaCl}$ were filtered as white solid. Single crystals were obtained from hexane layer diffusion into a DCM solution of product. FTIR ( $\mathrm{cm}^{-1}$, solid): 2183 .

\subsubsection{Synthesis of $(\mathrm{TBA})_{2}\left[\mathrm{Fe}_{3}\left(\mu_{3}-\mathrm{O}\right)\left(4-\mathrm{NO}_{2}-\mathrm{pz}\right)_{6}\left(\mathrm{~N}_{3}\right)_{3}\right](20)$}

A $30 \mathrm{~mL}$ vial was charged with $73 \mathrm{mg}(0.051 \mathrm{mmol})(\mathrm{TBA})_{2}\left[\mathrm{Fe}_{3}\left(\mu_{3}-\mathrm{O}\right)\left(4-\mathrm{NO}_{2}-\right.\right.$ pz) ${ }_{6} \mathrm{Cl}_{3}$ ], dissolved with $10 \mathrm{~mL}$ of DCM, followed by addition of $151.3 \mathrm{mg}(2.33 \mathrm{mmol})$ of $\mathrm{NaN}_{3}$. Reaction mixture was stirred for 24 hours and then filtered. Red plate single crystals were obtained from hexane layer diffusion into a DCM solution of product. FTIR (cm ${ }^{-1}$, solid): 2059. ${ }^{1} \mathrm{H}$ NMR (400 MHz, $\left.\mathrm{CD}_{2} \mathrm{Cl}_{2}\right) \delta 32.09\left(\mathrm{~s}, \mathrm{H}^{3}\right.$ and $\left.\mathrm{H}^{5}\right)$.

Complex was also obtained with $\mathrm{Ph}_{4} \mathrm{P}^{+}$counterion using similar condition but starting with the parent compound $\left(\mathrm{Ph}_{4} \mathrm{P}\right)_{2}\left[\mathrm{Fe}_{3}\left(\mu_{3}-\mathrm{O}\right)\left(4-\mathrm{NO}_{2}-\mathrm{pz}\right)_{6} \mathrm{Cl}_{3}\right]$.Complex was used for crystal structure determination since $\mathrm{TBA}^{+}$ions were disordered.

\subsubsection{Reduction of (20)}

Synthesis was done under inert atmosphere. A $30 \mathrm{~mL}$ flash was charged with 81 $\mathrm{mg}(0.055 \mathrm{mmol})$ of $(\mathrm{TBA})_{2}\left[\mathrm{Fe}_{3}\left(\mu_{3}-\mathrm{O}\right)\left(4-\mathrm{NO}_{2}-\mathrm{pz}\right)_{6}\left(\mathrm{~N}_{3}\right)_{3}\right]$ and dissolved in $10 \mathrm{~mL}$ of DCM. To the red solution, $18 \mathrm{mg}(0.07 \mathrm{mmol})$ of $\mathrm{TBABH}_{4}$ was added followed by an immediate color change to brown. After 40 minutes of stirring, the reaction was filtered. FTIR (cm ${ }^{-1}$, solid): 2042. ${ }^{1} \mathrm{H}$ NMR (400 $\left.\mathrm{MHz}, \mathrm{CDCl}_{3}\right) \delta 2.01\left(\mathrm{~s}, \mathrm{H}^{3}\right.$ and $\left.\mathrm{H}^{5}\right)$. 


\subsubsection{Oxidation of (20)}

A $25 \mathrm{~mL}$ flask was charged with $14.6 \mathrm{mg}(0.01 \mathrm{mmol})(\mathrm{TBA})_{2}\left[\mathrm{Fe}_{3}\left(\mu_{3}-\mathrm{O}\right)\left(4-\mathrm{NO}_{2}-\right.\right.$ $\left.\mathrm{pz})_{6}\left(\mathrm{~N}_{3}\right)_{3}\right]$ and dissolved with $10 \mathrm{~mL}$ of DCM. To the orange solution, $5.7 \mathrm{mg}(0.01$ mmol) of $\left[\left(\mathrm{NH}_{4}\right)_{2} \mathrm{Ce}\left(\mathrm{NO}_{3}\right)_{6}\right]$ were added and left to stir for 4 days. FTIR ( $\mathrm{cm}^{-1}$, solid): 2134. ${ }^{1} \mathrm{H}$ NMR (400 MHz, $\left.\mathrm{CD}_{2} \mathrm{Cl}_{2}\right) \delta 32.09$ and $8.60\left(\mathrm{~s}, \mathrm{H}^{3}\right.$ and $\left.\mathrm{H}^{5}\right)$.

\subsubsection{Crystal structure}

Refer to section 2.4.2 for structure refinement details. Disordered DCM solvent molecule in $\mathbf{2 0}$ was resolved by the SQUEEZE instruction.

Table 28. Structure refinement for complexes $\mathbf{1 8}$ and 19.

\begin{tabular}{|c|c|c|}
\hline Compound & (19) & (20) \\
\hline Empirical formula & $\mathrm{C}_{53} \mathrm{H}_{84} \mathrm{Fe}_{3} \mathrm{~N}_{23} \mathrm{O}_{16}$ & $\mathrm{C}_{66} \mathrm{H}_{51} \mathrm{Fe}_{3} \mathrm{~N}_{27} \mathrm{O}_{13} \mathrm{P}_{2}$ \\
\hline Formula weight & 1466.98 & 1659.82 \\
\hline Temperature/K & 273.15 & 293 \\
\hline Crystal system & monoclinic & monoclinic \\
\hline Space group & $P 2_{1} / n$ & $P 2_{l} / \mathrm{c}$ \\
\hline $\mathbf{a} / \AA ̊ \AA$ & $16.174(2)$ & $17.080(3)$ \\
\hline $\mathbf{b} / \AA$ & $27.200(3)$ & $16.665(3)$ \\
\hline $\mathbf{c} / \AA ̊$ & $17.853(2)$ & $30.856(6)$ \\
\hline$\alpha /{ }^{\circ}$ & 90 & 90 \\
\hline$\beta /{ }^{\circ}$ & $90.897(3)$ & $97.43(3)$ \\
\hline$\gamma /{ }^{\circ}$ & 90 & 90 \\
\hline Volume $/ \AA^{3}$ & $7853(2)$ & $8709(3)$ \\
\hline $\mathbf{Z}$ & 4 & 4 \\
\hline$\rho_{\text {calc }} \mathbf{g} / \mathrm{cm}^{3}$ & 1.241 & 1.266 \\
\hline$\mu / \mathbf{m m}^{-1}$ & 0.616 & 0.599 \\
\hline $\mathbf{F}(000)$ & 3076.0 & 3392.0 \\
\hline Crystal size $/ \mathrm{mm}^{3}$ & $0.317 \times 0.176 \times 0.114$ & $0.426 \times 0.324 \times 0.142$ \\
\hline $2 \Theta$ range for data collection $/{ }^{\circ}$ & 5.618 to 52.958 & 5.706 to 53.188 \\
\hline Reflections collected & 160914 & 104661 \\
\hline Data/restraints/parameters & $16121 / 0 / 864$ & $17927 / 0 / 1000$ \\
\hline Goodness-of-fit on $\mathbf{F}^{2}$ & 0.996 & 0.993 \\
\hline $\mathbf{R}_{1}, \mathbf{w R}_{2}[\mathrm{I}>=\mathbf{2 \sigma}(\mathrm{I})]$ & $0.0946,0.1677$ & $0.0746,0.2022$ \\
\hline $\mathbf{R}_{1}, \mathbf{w R}_{2}$ [all data] & $0.2437,0.2171$ & $0.1320,0.2439$ \\
\hline
\end{tabular}




\section{Conclusions and future work}

\section{Chromium pyrazole/pyrazolate:}

In order to be able to access materials that would simplify the analysis of magnetic data of mixed-valent trinuclear and octanuclear iron pyrazolate complexes, the synthesis of redox active chromium polynuclear complexes was in order. Results are summarized in Scheme 12. Stable mononuclear complexes of form $\left[m e r-\mathrm{Cr}_{3} \mathrm{Cl}_{3}\left(\mathrm{pzH}^{*}\right)_{3}\right]$ $\left(\mathrm{pzH}^{*}=\mathrm{pzH}, 3-\mathrm{Me}-\mathrm{pzH}, 4-\mathrm{Me}-\mathrm{pzH}, 4-\mathrm{Cl}-\mathrm{pzH}, 4-\mathrm{I}-\mathrm{pzH}, 4-\mathrm{Br}-\mathrm{pzH}\right)$ and [trans$\left.\mathrm{Cr}_{3} \mathrm{Cl}_{2}\left(\mathrm{pzH}^{*}\right)_{4}\right] \mathrm{Cl}\left(\mathrm{pzH}^{*}=\mathrm{pzH}, 3-\mathrm{Me}-\mathrm{pzH}\right)$ formed from the use of hydrated or anhydrous chromium chloride salts. Due to intermediate spin relaxation of the aforementioned mononuclear complexes, they were NMR and EPR active. Variable temperature NMR was able to elucidate that peaks arise from two pyrazole environments, pyrazole trans to a pyrazole and pyrazole trans to a chloride. Pyrazole tautomerization becomes slow at low temperatures, where individual signals are observed for the $\mathrm{H}^{3} / \mathrm{H}^{5}$ positions of the pyrazole.

Analogous to iron pyrazolate chemistry, where the reaction of mononuclear complexes with base yields octanuclear complexes, monomers of chromium were reacted with base and proven unsuccessful. Trace amounts of trinuclear complex $\left[\mathrm{Cr}_{3}^{\mathrm{III}}{ }_{3}\left(\mu_{3}-\mathrm{O}\right)(\mu-\right.$ $\mathrm{OH})_{3}(3-\mathrm{Me}-\mathrm{pzH})_{9} \mathrm{Cl}_{4}$ and dinuclear chromium species of formula $\mathrm{Cr}_{2}^{\mathrm{III}}(\mu-\mathrm{OH})(\mu-4-\mathrm{Me}-$ pz)(4-Me-pzH $\left.\left.)_{4} \mathrm{Cl}_{2}\right] \mathrm{Cl}_{4}\right]$ and $\left.\left[\mathrm{Cr}_{2}^{\mathrm{III}}(\mu-\mathrm{OH})(\mu-4-\mathrm{R}-\mathrm{pz})_{2}(4-\mathrm{R}-\mathrm{pzH})_{4} \mathrm{Cl}_{2}\right] \mathrm{Cl}\right](\mathrm{R}=\mathrm{pzH}, 4-\mathrm{Me}-$ $\mathrm{pzH}$, 4-Cl-pzH) are isolated from the mononuclear chromium pyrazole synthesis, providing the source of complexity in product isolation.

The use of chromium nitrate nonahydrate proved to be efficient in avoiding the formation of stable complexes of form $\left[\right.$ mer $\left.-\mathrm{Cr}_{3} \mathrm{Cl}_{3}\left(\mathrm{pzH}^{*}\right)_{3}\right]$ and to obtain higher 
nuclearity complexes. The hydrolysis of DMF accessed new redox inactive trinuclear mixed-ligand formate-pyrazolate chromium complexes with form $\left[\mathrm{Cr}_{3}^{\mathrm{III}}\left(\mu_{3}-\mathrm{O}\right)(\mu-4-\mathrm{R}-\right.$ $\left.\mathrm{pz})_{3}\left(\mu-\mathrm{O}_{2} \mathrm{CH}\right)_{3}(\mathrm{DMF})_{3}\right]^{-}(\mathrm{R}=\mathrm{H}, \mathrm{Me}, \mathrm{Cl})$. From the obtained complexes, a nonhydrolyzing solvent use was in order to obtain all-pyrazolate complexes.

Thermally assisted synthesis using butyronitrile afforded $\left(\mathrm{Ph}_{4} \mathrm{P}\right)_{2}\left[\mathrm{Cr}_{3}\left(\mu_{3}-\mathrm{O}\right)(\mu-4-\right.$ $\left.\mathrm{Cl}-\mathrm{pz})_{6}\right]^{2-}\left(\mathrm{X}=\mathrm{Cl}^{-}, \mathrm{Br}^{-}\right)$. The two step synthesis produces an intermediate with form $\left\{\mathrm{Cr}_{3}\left(\mu_{3}-\mathrm{O}\right)(\mu-4-\mathrm{Cl}-\mathrm{pz})_{6} \mathrm{X}_{3}\right\}^{2-}$, where the terminal ligand can be solvent molecules or $\mathrm{NO}_{3}{ }^{-}$ anions, addition of terminal ligand source affords the final product. Electrochemical studies of $\left[\mathrm{Cr}_{3}\left(\mu_{3}-\mathrm{O}\right)(\mu-4-\mathrm{Cl}-\mathrm{pz})_{6} \mathrm{Cl}_{3}\right]^{2-}$ showed a one electron oxidation process at $\mathrm{E}_{1 / 2}=$ $0.502 \mathrm{~V}$, producing a mixed-valent, formally $\mathrm{Cr}_{3}^{\mathrm{III}} / \mathrm{Cr}^{\mathrm{IV}} \mathrm{Cr}_{2}^{\mathrm{III}}$ species. Electrochemical studies of $\left[\mathrm{Cr}_{3}\left(\mu_{3}-\mathrm{O}\right)(\mu-4-\mathrm{Cl}-\mathrm{pz})_{6} \mathrm{Br}_{3}\right]^{2-}$ showed two oxidation processes, where the first process $\left(\mathrm{E}_{1 / 2}=0.332 \mathrm{~V}\right)$ became an easier oxidation and a second process $\left(\mathrm{E}_{1 / 2}=0.584\right.$ V) became accessible, generating $\mathrm{Cr}_{3}^{\mathrm{III}} / \mathrm{Cr}^{\mathrm{IV}} \mathrm{Cr}^{\mathrm{III}}{ }_{2}$ and $\mathrm{Cr}_{3}^{\mathrm{III}} / \mathrm{Cr}^{\mathrm{IV}}{ }_{2} \mathrm{Cr}^{\mathrm{III}}$ species, respectively.

\section{Iron pyrazolate:}

Upon the one electron reduction of $\left[\mathrm{Fe}_{3}\left(\mu_{3}-\mathrm{O}\right)\left(4-\mathrm{NO}_{2}-\mathrm{pz}\right)_{6}(\mathrm{SCN})_{3}\right]^{2-}$ complex, a spin cascade is produced, resulting in a HS to LS electronic reorganization of the complex. To obtain complexes that share similar properties, $\left[\mathrm{Fe}_{3}\left(\mu_{3}-\mathrm{O}\right)\left(4-\mathrm{NO}_{2}-\mathrm{pz}\right)_{6} \mathrm{~L}_{3}\right]^{2-}$ $\left(\mathrm{L}=\mathrm{N}_{3}^{-}, \mathrm{CNO}^{-}\right)$were synthesized. Electrochemical properties of both complexes were studies, both showed a reversible one electron reduction at $-0.70 \mathrm{~V}$, harder reduction compared to the $\mathrm{SCN}^{-}$complex $(-0.36 \mathrm{~V})$. Most interestingly, $\left[\mathrm{Fe}_{3}\left(\mu_{3}-\mathrm{O}\right)\left(\mu-4-\mathrm{NO}_{2}-\right.\right.$ $\left.\mathrm{pz})_{6}\left(\mathrm{~N}_{3}\right)_{3}\right]^{2-}$ showed a unique oxidation process $(0.82 \mathrm{~V})$ that can access $\left[\mathrm{Fe}_{3}\left(\mu_{3}-\mathrm{O}\right)(\mu-4-\right.$ $\left.\left.\mathrm{NO}_{2}-\mathrm{pz}\right)_{6}\left(\mathrm{~N}_{3}\right)_{3}\right]^{-}$, a mixed-valent, formally $\mathrm{Fe}^{3+}{ }_{2} / \mathrm{Fe}^{4+}$ species. 
Mössbauer data of $\left[\mathrm{Fe}_{3}\left(\mu_{3}-\mathrm{O}\right)\left(\mu-4-\mathrm{NO}_{2}-\mathrm{pz}\right)_{6}\left(\mathrm{~N}_{3}\right)_{3}\right]^{3-}$ is consistent with a all-ferric complex. After chemical reduction with $\mathrm{TBABH}_{4}$, the single doublet with a reduced isomer shift $\left(\delta=0.40 \mathrm{mms}^{-1}\right)$ and quadrupole splitting $\left(\Delta \mathrm{E}_{\mathrm{Q}}=0.83 \mathrm{mms}^{-1}\right)$ indicates a charge delocalization within the complex and a LS species. This experiment is suggestive of a spin crossover from $\mathrm{HS}$ to $\mathrm{LS}$, similar to the previously reported $\left[\mathrm{Fe}_{3}\left(\mu_{3}-\mathrm{O}\right)\left(4-\mathrm{NO}_{2}-\right.\right.$ $\left.\mathrm{pz})_{6}(\mathrm{SCN})_{3}\right]^{2-}$ complex.

\section{Future work}

- Further study of terminal ligand effect on electrochemical properties is to follow. Same reaction conditions and the addition of desired terminal ligand should result in new complexes (e.g. $\mathrm{SCN}^{-}, \mathrm{N}_{3}^{-}, \mathrm{CN}^{-}$, py)

- Following up on the redox activity of chromium pyrazolate complexes, chemical oxidation should afford mixed-valent species. Changes in the UV-Vis-NIR spectra should be expected, where shifts in CT bands or IVCT would be affected by terminal ligand identity, as seen for trinuclear pyrazolate complexes.

- Since mixed-ligand formate-pyrazolate complexes were synthesized with the 4-R-pzH $(\mathrm{R}=\mathrm{H}, \mathrm{Me}, \mathrm{Cl})$, the all-pyrazolate complex with pyrazole and 4-Me-pyrazole should be obtained with the synthesis method presented here. Studying such complexes would give insight of the effects of pyrazole substitution on the electrochemical properties. Such studies are not accessible for trinuclear iron, since complexes are only obtained with the 4- $\mathrm{NO}_{4}-\mathrm{pzH}$ ligand.

- Mössbauer spectroscopy of mixed-valent species from chemical oxidation of $\left[\mathrm{Fe}_{3}\left(\mu_{3^{-}}\right.\right.$ $\left.\mathrm{O})\left(\mu-4-\mathrm{NO}_{2}-\mathrm{pz}\right)_{6}\left(\mathrm{~N}_{3}\right)_{3}\right]^{1-}$ is in order to elucidate charge localization. 


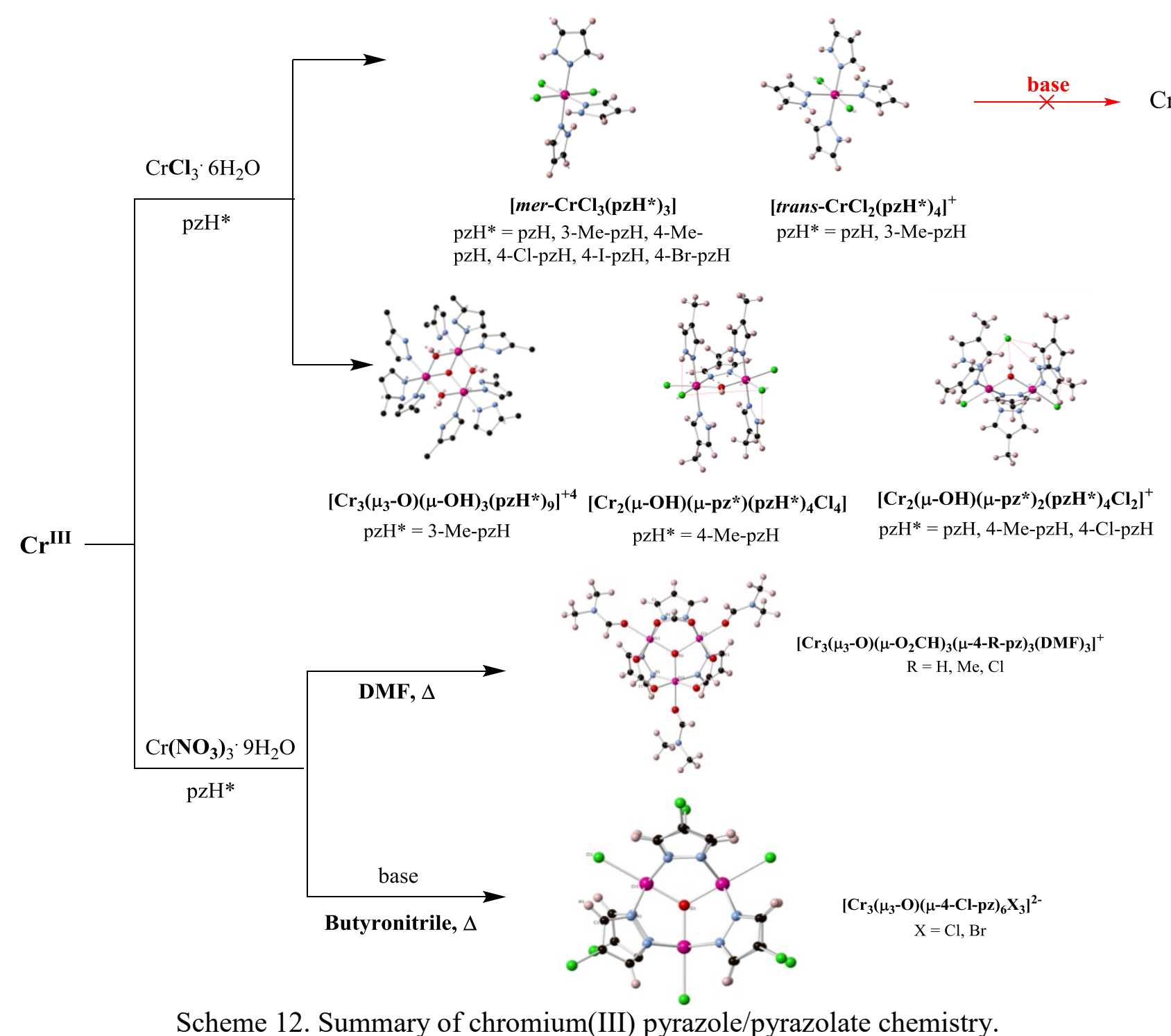


References

(1) Memarzadeh, K.; Vargas, M.; Huang, J.; Fan, J.; Allaker, R. Nano Metallic-Oxides as Antimicrobials for Implant Coatings. Key Eng. Mat. 2012, 489-494.

(2) Anpo, M. Utilization of TiO2 Photocatalysts in Green Chemistry. Pure Appl. Chem. 2000, 72, 1265-1270.

(3) Batzill, M. Fundamental Aspects of Surface Engineering of Transition Metal Oxide Photocatalysts. Energy Environ. Sci. 2011, 3275-3286.

(4) Burr, G. W.; Kurdi, B. N.; Scott, J. C.; Lam, C. H.; Gopalakrishnan, K. Overview of Candidate Device Technologies for Storage-Class Memory. IBM J. Res. Dev. 2008, 52, 449-464.

(5) Kung, H. H. Transition Metal Oxides: Surface Chemistry and Catalysis; Delmon, D.; Yates, J. T., Eds.; Studies in Surface Science and Catalysis; 1st ed.; Elsevier Science: New York, NY, 1989.

(6) Ding, Y.-H. R.; Hixson, K. K.; Aklujkar, M. A.; Lipton, M. S.; Smith, R. D.; Lovley, D. R.; Mester, T. Proteome of Geobacter Sulfurreducens Grown with Fe(III) Oxide or Fe(III) Citrate as the Electron Acceptor. BBA - Proteins Proteomics. 2008, 1784, 1935-1941.

(7) Mayo, S. L.; Ellis, W. R.; Crutchley, R. T.; Gray, H. B. Long-Range Electron Transfer in Heme Proteins. Science. 1986, 233, 948-952.

(8) Reynolds, J. G.; Coyle, C. L.; Holm, R. H. Electron Exchange Kinetics of [Fe4S4(SR)4]2-/ [Fe4S4(SR)4]3-and [Fe4Se4(SR)4]2-/[Fe4Se4(SR)4]3-Systems. Estimates of the Intrinsic Self-Exchange Rate Constant of 4-Fe Sites in Oxidized and Reduced Ferredoxins. J. Am. Chem. Soc. 1980, 102, 4350-4355.

(9) Lancaster, K.; Odom, S. A.; Jones, S. C.; Thayumanavan, S.; Marder, S. R.; Brédas, J. L.; Coropceanu, V.; Barlow, S. Intramolecular Electron-Transfer Rates in Mixed-Valence Triarylamines: Measurement by Variable-Temperature ESR Spectroscopy and Comparison with Optical Data. J. Am. Chem. Soc. 2009, 131, $1717-1723$.

(10) Brendan, P.; Spectroscopy, T.; Charge, M.; Macpherson, B. P.; Bernhardt, P. V; Hauser, A. Article Time-Resolved Spectroscopy of the Metal-to-Metal Charge Transfer Excited State in Dinuclear Cyano-Bridged Mixed-Valence Complexes. Inorg. Chem. 2005, 44, 5530-5536.

(11) Chisholm, M. H.; Patmore, N. J. Studies of Electronic Coupling and Mixed Valency in Metal-Metal Quadruply Bonded Complexes Linked by Dicarboxylate and Closely Related Ligands. Acc. Chem. Res. 2007, 40, 19-27. 
(12) Coey, J. M. D.; Viret, M.; Von Molnár, S. Mixed-Valence Manganites. Adv. Phys. 2009, 58, 571-697.

(13) Jordan E. Katz; Zhang, X.; Attenkofer, K.; Chapman, K. W.; Frandsen, C.; Zarzycki, P.; Rosso, K. M.; Falcone, R. W.; Waychunas, G. a.; Gilbert, B.; et al. Electron Small Polarons and Their Mobility in Iron (Oxyhydr)Oxide Nanoparticles. Science. 2012, 337, 1200-1203.

(14) Sengupta, K.; Chatterjee, S.; Samanta, S.; Bandyopadhyay, S.; Dey, A. Resonance Raman and Electrocatalytic Behavior of Thiolate and Imidazole Bound Iron Porphyrin Complexes on Self Assembled Monolayers: Functional Modeling of Cytochrome P450. Inorg. Chem. 2013, 52, 2000-2014.

(15) Zheng, S.; Berto, T. C.; Dahl, E. W.; Hoffman, M. B.; Speelman, A. L.; Lehnert, $\mathrm{N}$. The Functional Model Complex [Fe2(BPMP)(OPr)(NO)2](BPh4)2provides Insight into the Mechanism of Flavodiiron NO Reductases. J. Am. Chem. Soc. 2013, 135, 4902-4905.

(16) Feringa, B. L.; Gelling, O.-J.; Rispens, M. T.; Lubben, M. Self-Assembly of Mono- and Dinuclear Metal Complexes; Oxidation Catalysis and Metalloenzyme Models. In Transition Metals in Supramolecular Chemistry. NATO ASI Series (Series C: Mathematical and Physical Sciences); Fabbrizzi, L.; Poggi, A., Eds.; Springer: Dordrecht, 1994; Vol. 448, pp. 171-190.

(17) Tshuva, E. Y.; Lippard, S. J. Synthetic Models for Non-Heme CarboxylateBridged Diiron Metalloproteins: Strategies and Tactics. Chem. Rev. 2004, 104, 987-1012.

(18) Trofimenko, S. The Coordination Chemistry of Pyrazole-Derived Ligands. Chem. Rev. 1972, 72, 497-509.

(19) Milios, C. J.; Stamatatos, T. C.; Perlepes, S. P. The Coordination Chemistry of Pyridyl Oximes. Polyhedron 2006, 25, 134-194.

(20) Christou, G. Single-Molecule Magnets: A Molecular Approach to Nanoscale Magnetic Materials. Polyhedron 2005, 24, 2065-2075.

(21) Viciano-Chumillas, M.; Tanase, S.; De Jongh, L. J.; Reedijk, J. Coordination Versatility of Pyrazole-Based Ligands towards High-Nuclearity Transition-Metal and Rare-Earth Clusters. Eur. J. Inorg. Chem. 2010, 3403-3418.

(22) Wallar, B. J.; Lipscomb, J. D. Dioxygen Activation by Enzymes Containing Binuclear Non-Heme Iron Clusters. Chem. Rev. 1996, 96, 2625-2658.

(23) Mauerer, B.; Crane, J.; Schuler, J.; Wieghardt, K.; Nuber, B. A Hemerythrin Model Complex with Catalase Activity. Angew. Chem. Int. Ed. Engl. 1993, 32, 289-291. 
(24) La Monica, G.; Ardizzoia, G. A. The Role of the Pyrazolate Ligand in Building Polynuclear Transition Metal Systems. Prog. Inorg. Chem. 1997, 46, 151-238.

(25) Mani, F. Model Systems Containing Pyrazole Chelates and Related Groups: Recent Developments and Perspectives. Coord. Chem. Rev. 1992, 325-359.

(26) Faria, J. V.; Vegi, P. F.; Miguita, A. G. C.; dos Santos, M. S.; Boechat, N.; Bernardino, A. M. R. Recently Reported Biological Activities of Pyrazole Compounds. Bioorg. Med. Chem. 2017, 25, 5891-5903.

(27) Ganguly, Swastika; Jacob, S. K. Therapeutic Outlook of Pyrazole Analogs: A Mini Review. Mini-Reviews Med. Chem. 2017, 17, 959-983.

(28) Halcrow, M. A. Pyrazoles and Pyrazolides-Flexible Synthons in Self-Assembly. Dalton Trans. 2009, 12, 2059-2073.

(29) Umakoshi, K.; Yamauchi, Y.; Nakamiya, K.; Kojima, T.; Yamasaki, M.; Kawano, H.; Masayoshi Onishi. Pyrazolato-Bridged Polynuclear Palladium and Platinum Complexes. Synthesis, Structure, and Reactivity. Inorg. Chem. 2003, 42, 39073916.

(30) Baran, P.; Marrero, C. M.; Pérez, S.; Raptis, R. G. Stepwise, Ring-Closure Synthesis and Characterization of a Homoleptic Palladium(II)-Pyrazolato Cyclic Trimer. Chem. Commun. 2002, 1012-1013.

(31) Miras, H. N.; Chakraborty, I.; Raptis, R. G. Tri-, Deca-and Dodecanuclear Co(III)pyrazolate Metallacyclesw. Chem. Commun. 2010, 46, 2569-2571.

(32) Bond, A. M.; Clark, R. J. H.; Humphrey, D. G.; Panayiotopoulos, P.; Skelton, B. W.; White, A. H. Synthesis, Characterisation and Electrochemical Reductions of Oxo-Centred, Carboxylate-Bridged Triiron Complexes, [Fe3 (M3 -O)-( $\mu$ O2CR)6L3]X ( $\mathrm{R}=\mathrm{Me}$, But, $\mathrm{Ph}, \mathrm{CH} 2 \mathrm{Cl}, \mathrm{CCl} 3, \mathrm{CH} 2 \mathrm{CN}$ Or4-NO2C6 H ; L = Py, 3-H2Npy, 4-H2Npy, 3-NCpy, 4-NCpy or 4-CH2 CHpy; X = . Dalt. Trans. 1998, $1845-1852$.

(33) Piñero, D.; Baran, P.; Boca, R.; Herchel, R.; Klein, M.; Raptis, R. G.; Renz, F.; Sanakis, Y. A Pyrazolate-Supported Fe(3)(M3-O) Core: Structural, Spectroscopic, Electrochemical, and Magnetic Study. Inorg. Chem. 2007, 46, 10981-10989.

(34) Govor, E. V.; Al-Ameed, K.; Chakraborty, I.; Coste, C. S.; Govor, O.; Sanakis, Y.; McGrady, J. E.; Raptis, R. G. A Redox-Induced Spin-State Cascade in a MixedValent Fe3(M3-O) Triangle. Angew. Chemie - Int. Ed. 2017, 56, 582-586.

(35) Sameera, W. M. C.; Piñero, D. M.; Herchel, R.; Sanakis, Y.; McGrady, J. E.; Raptis, R. G.; Zueva, E. M. A Combined Experimental and Computational Study of the Magnetic Superexchange within a Triangular (M3-O)-Pyrazolato-FeIII3 Complex. Eur. J. Inorg. Chem. 2012, 21, 3500-3506. 
(36) Bancroft, P.; Albert, F.; Falvello, L. R. Synthesis and Characterization of Trinuclear Palladium Complexes. Polyhedron 1987, 615-621.

(37) Beattie, J. K.; Hambley, T. W.; Klepetko, J. A.; Masters, A. F.; Turner, P. The Chemistry of Cobalt Acetate: The Isolation and Crystal Structure of the Symmetric Trimer, Hexakis( $\mu$-Acetato)-M3-Oxotris(Pyridine)Tricobalt(III) Perchlorate Water Solvate, [Co3O(CH3CO2)6(C5H5N)3][CIO4] · H2O. Polyhedron 1996, 15, 2141-2150.

(38) Dobson, A.; Robinson, S. D. Carboxylato Complexes of the Platinum Group Metals. Platin. Met. Rev. 1976, 20, 56-63.

(39) Murrie, M.; Parsons, S.; E. P. Winpenny, R.; M. Atkinson, I.; Benelli, C. Turning up the Heat: Synthesis of Octanuclear Chromium(III) Carboxylates. Chem. Commun. 1999, 285-286.

(40) Baran, P.; Boča, R.; Chakraborty, I.; Giapintzakis, J.; Herchel, R.; Huang, Q.; McGrady, J. E.; Raptis, R. G.; Sanakis, Y.; Simopoulos, A. Synthesis, Characterization, and Study of Octanuclear Iron-Oxo Clusters Containing a Redox-Active Fe4O4-Cubane Core. Inorg. Chem. 2008, 47, 645-655.

(41) Keller, G. Rock and Mineral Properties. In Electromagnetic methods in applied geophysics; Nabighian, M., Ed.; Society of Exploration Geophysicists: Tulsa, OK, 1987; pp. 22-37.

(42) Peligot, E. Sur Un Nouvel Oxide de Chrome. C. R. Acad. Sci. 1844, 19, 609.

(43) van Niekerk, J. N.; Schoening, F. R. L.; de Wet, J. F. The Structure of Crystalline Chromous Acetate Revealing Paired Chromium Atoms. Acta Crystallogr. 1953, 6, 501-504.

(44) Cotton, F. A. Chromium Compounds. In Multiple Bonds between Metal Atoms; Cotton, F. A.; Murillo, C. A.; Walton, R. A., Eds.; Springer Science \& Business Media: New York, NY, 2005; pp. 35-68.

(45) Hsu, C. W.; Yu, J. S. K.; Yen, C. H.; Lee, G. H.; Wang, Y.; Tsai, Y. C. QuintuplyBonded Dichromium(I) Complexes Featuring Metal-Metal Bond Lengths of 1.74 Å. Angew. Chemie - Int. Ed. 2008, 47, 9933-9936.

(46) Sadique, A. R.; Heeg, M. J.; Winter, C. H. A Weak, Short Metal-Metal Bond in a Chromium(II) Amidinate Complex. J. Am. Chem. Soc. 2003, 125, 7774-7775.

(47) Albert Cotton, F.; Murillo, C. A.; Zhou, H. C. A Dichromium(II,II) Compound with a Strong Antiferromagnetic Coupling but Little or No Cr-Cr Bonding. Inorg. Chem. 2000, 39, 3728-3730.

(48) Edema, J. J. H.; Gambarotta, S.; Meetsma, A.; van Bolhuis, F.; Spek, A. L.; Smeets, W. J. J. The Unpredictable Structural Features of Chromium(II) Pyrrolyls: 
Synthesis and X-Ray Structures of Monomeric Square-Planar (V-2,5Me2C4H2N)2Cr(Py)2, Square-Pyramidal (H1-C4H4N)2Cr(Py)3, Dimeric [(7Azaindolyl)2Cr(DMF)]2, and Polymeric [(H1-2,5-Me2C4N2)4Cr. Inorg. Chem. 1990, 29, 2147-2153.

(49) Ndambuki, S.; Ziegler, T. A Theoretical Analysis of Supported Quintuple and Quadruple Chromium-Chromium Bonds. Inorg. Chem. 2013, 52, 3860-3869.

(50) Brynda, M.; Gagliardi, L.; Roos, B. O. Analysing the Chromium-Chromium Multiple Bonds Using Multiconfigurational Quantum Chemistry. Chem. Phys. Lett. 2009, 471, 1-10.

(51) Cotton, F. A.; Extine, M.; Gage, L. D. Sensitivity of the Chromium-Chromium Quadruple Bond in the Dichromium Tetracarboxylates to Axial Coordination and Changes in Inductive Effects. Inorg. Chem. 1978, 17, 172-176.

(52) Cotton, F. A.; Hillard, E. A.; Murillo, C. A.; Zhou, H. C. After 155 Years, a Crystalline Chromium Carboxylate with a Supershort Cr-Cr Bond. J. Am. Chem. Soc. 2000, 122, 416-417.

(53) El-Kadri, O. M.; Heeg, M. J.; Winter, C. H. Synthesis, Structure, and Properties of a Dimeric Chromium(II) Pyrazolato Complex with a Long Chromium-Chromium Distance. Maintenance of a Dimeric Structure in Solution and Interconversion between Dimeric and Monomeric Structures. Inorg. Chem. 2006, 45, 5278-5280.

(54) Demadis, K. D.; Hartshorn, C. M.; Meyer, T. J. The Localized-to-Delocalized Transition in Mixed-Valence Chemistry. Chem. Rev. 2001, 101, 2655-2686.

(55) Boldyrev, S. I.; Gamurar, V. Y.; Tsukerblat, B. S.; Palii, A. V. Vibronic Interaction in Multielectronic Mixed-Valence Trimeric Clusters. Mol. Phys. 1994, $81,621-654$.

(56) Bominaar, E. L.; A., B. S.; Girerd, J.-J. Double-Exchange and Vibronic Coupling in Mixed-Valence Systems. Electronic Structure of [Fe4S4]3+ Clusters in HighPotential Iron Protein and Related Models. J. Am. Chem. Soc. 1994, 116, 53625372.

(57) Belinskii, M. I. Electronic Interaction in Trimeric Mixed Valence Clusters. Mol. Phys. 1987, 60, 793-819.

(58) Govor, E. V.; Chakraborty, I.; Piñero, D. M.; Baran, P.; Sanakis, Y.; Raptis, R. G. Structural and 57Fe-Mössbauer Characterization of Mononuclear Ferrous and Ferric Pyrazole Complexes. Polyhedron 2012, 45, 55-60.

(59) McInnes, E. J. L.; Piligkos, S.; Timco, G. A.; Winpenny, R. E. P. Studies of Chromium Cages and Wheels. Coord. Chem. Rev. 2005, 249, 2577-2590. 
(60) McInnes, E. J. L.; Anson, C.; Powell, A. K.; Thomson, A. J.; Poussereau, S.; Sessoli, R. Solvothermal Synthesis of [Cr10 $(\mu-\mathrm{O} 2 \mathrm{CMe}) 10(\mu-\mathrm{OR}) 20]$ "chromic Wheels" with Antiferromagnetic $(\mathrm{R}=\mathrm{Et})$ and Ferromagnetic $(\mathrm{R}=\mathrm{Me})$ (Cr(III) $\cdots \mathrm{Cr}$ (III). Chem. Commun. 2001, 10, 89-90.

(61) Low, D. M.; Jones, L. F.; Bell, A.; Brechin, E. K.; Mallah, T.; Rivière, E.; Teat, S. J.; McInnes, E. J. L. Solvothermal Synthesis of a Tetradecametallic FeIII Cluster. Angew. Chemie Int. Ed. 2003, 42, 3781-3784.

(62) Low, D. M.; Brechin, E. K.; Helliwell, M.; Mallah, T.; Rivière, E.; McInnes, E. J. L. New Routes to High Nuclearity Cages: Dimerisation of a Manganese Triangle via Solvothermal Synthesis. Chem. Commun. 2003, 3, 2330-2331.

(63) Shaw, R.; Tidmarsh, I. S.; Laye, R. H.; Breeze, B.; Helliwell, M.; Brechin, E. K.; Heath, S. L.; Murrie, M.; Ochsenbein, S.; Güdel, H.-U.; et al. Supertetrahedral Decametallic Ni(II) Clusters Directed by M6-Tris-Alkoxides. Chem. Commun. 2004, 1418-1419.

(64) Mani, F.; Scapacci, G. Chromium (II) Complexes with Pyrazoles and Imidazoles as Ligands. Inorganica Chim. Acta 1976, 16, 163-166.

(65) Gonzalez Garmendia, M. J. J.; Losada, J.; Moran, M. Electron Paramagnetic Resonance and Electronic Spectroscopy Studies of Some Complexes of Cr(III) with Imidazoles. J. Inorg. Nucl. Chem. 1981, 43, 2269-2271.

(66) Bryan, R. F.; Greene, P. T.; Stokely, P. F.; Wilson, E. W. Crystal and Molecular Structure of Tris(Glycinato)Chromium(III) Monohydrate, Cr(C2H4NO2)3.H2O. Inorg. Chem. 1971, 10, 1468-1473.

(67) Prior, T. J.; Maples, D. L.; Maples, R. D.; Hoffert, W. A.; Parsell, T. H.; Silversides, J. D.; Archibald, S. J.; Hubin, T. J. Crystal Structures of Two CrossBridged Chromium(III) Tetraazamacrocycles. Acta Crystallogr. Sect. E Struct. Reports Online 2014, 70, 148-152.

(68) Bondi, A. Van Der Waals Volumes and Radii. J. Phys. Chem. 1964, 68, 441-451.

(69) Desiraju, G. R.; Parthasarathy, R. The Nature of Halogen-Halogen Interactions: Are Short Halogen Contacts Due to Specific Attractive Forces or Due to Close Packing of Nonspherical Atoms? J. Am. Chem. Soc. 1989, 111, 8725-8726.

(70) Ballhausen, C. J. Introduction to Ligand Field Theory; MeGraw-Hill Book Co.: New York, 1962.

(71) Lever, A. B. P. The Crystal Field Splitting Parameter Dq: Calculation and Significance. Adv. Chem. 1967, 62, 430-451.

(72) Staszak, Z. Solvent Effects on the Electronic Absorption Spectra of Cr(III) Complexes. Spectrosc. Lett. 1988, 21, 981-991. 
(73) Hush, N. S.; Reimers, J. R. Solvent Effects on the Electronic Spectra of Transition Metal Complexes. Chem. Rev. 2000, 100, 775-786.

(74) Satterlee, J. D. Fundamental Concepts of NMR in Paramagnetic Systems. Part II: Relaxation Effects. Concepts Magn. Reson. 1990, 2, 119-129.

(75) Hagen, W. R. Broadband Transmission EPR Spectroscopy. PLoS One 2013, 8, 115.

(76) Weil, J. A.; Bolton, J. R. Electron Paramagnetic Resonance: Elementary Theory and Practical Applications; 2nd ed.; Wiley: NJ, 2007.

(77) Keller, H. J.; Schwarzhans, K. E. Magnetic Resonance of Paramagnetic Complexes. Angew. Chem. Int. Ed 1970, 9, 196-205.

(78) Bertini, I.; Luchinat, C.; Parigi, G.; Ravera, E.; Bertini, I.; Luchinat, C.; Parigi, G.; Ravera, E. Transition Metal Ions: Shift and Relaxation. In NMR of Paramagnetic Molecules; 2017; pp. 175-253.

(79) Sharp, R. R. Effect of Zero Field Splitting Interactions on the Paramagnetic Relaxation Enhancement of Nuclear Spin Relaxation Rates in Solution. J. Chem. Phys. 1993, 98, 912-921.

(80) Abernathy, S. M.; Sharp, R. R. Role of Zero-Field Splitting Interactions in the NMR Paramagnetic Relaxation Enhancements Produced by Ni(II)(Acac) 2 (H 2 O) 2. J. Phys. Chem. A 1997, 101, 3692-3698.

(81) Gowda, A. S.; Petersen, J. L.; Milsmann, C. Redox Chemistry of Bis(Pyrrolyl)Pyridine Chromium and Molybdenum Complexes: An Experimental and Density Functional Theoretical Study. Inorg. Chem. 2018, 57, 1919-1934.

(82) Freitas, A. R.; Silva, M.; Ramos, M. L.; Justino, L. L. G.; Fonseca, S. M.; Barsan, M. M.; Brett, C. M. A.; Silva, M. R.; Burrows, H. D. Synthesis, Structure, and Spectral and Electrochemical Properties of Chromium(III) Tris-(8Hydroxyquinolinate). Dalt. Trans. 2015, 44, 11491-11503.

(83) McGarvey, B. R. Theory of Contact and Dipolar Nuclear Magnetic Resonance Shifts in Tetrahedral Nickel (II) Complexes. J. Am. Chem. Soc. 1972, 94, $1103-$ 1108 .

(84) Akitt, J. W. N.M.R. and Chemistry; Chapman and Hall: London, 1973.

(85) Blümel, J.; Herker, M.; Hiller, W.; Köhler, F. H. Study of Paramagnetic Chromocenes by Solid-State NMR Spectroscopy. Organometallics 1996, 15, 3474-3476.

(86) Louro, R. O.; Medina, M.; Aguiar, A. P.; Hervás, M.; De La Rosa, M.; GómezMoreno, C.; Turner, D. L.; Xavier, A. V. Structural and Magnetic Characterisation of the Haem Core of Ferricytochromes C6. J. Biol. Inorg. Chem. 1998, 3, 68-73. 
(87) Banci, L.; Bertini, I.; Luchinat, C.; Pierattelli, R.; Shokhirev, N. V.; Walker, F. A. Analysis of the Temperature Dependence of the 1H and 13C Isotropic Shifts of Horse Heart Ferricytochrome C: Explanation of Curie and Anti-Curie Temperature Dependence and Nonlinear Pseudocontact Shifts in a Common Two- Level Framework. J. Am. Chem. Soc. 1998, 120, 8472-8479.

(88) Carlson, H. The Validity of Approximate Equations for Kc in Dynamic Nuclear Magnetic Resonance. Chem. Commun 1971, 13, 656-657.

(89) Nesee, F. Spin-Hamiltonian Parameters for First Principle Calculations: Theoy and Application. In High Resolution EPR; Berliner, L.; Hanson, G., Eds.; Spriger, 2009; pp. 175-229.

(90) Abragam, A.; Bleanley, B. Electron Paramagnetic Resonance of Transition Ions; Claredon Press: Oxford, UK, 1970.

(91) Eilbeck, W. J.; Holmes, F.; Underhill, A. E. Cobalt(II), Nickel(II), and Copper(II) Complexes of Imidazole and Thiazole. J. Chem. Soc. A 1967, 757-761.

(92) Bonomo, R. P.; Di Bilio, A. J.; Riggi, F. EPR Investigation of Chromium (III) Complexes: Analysis of Their Frozen Solution and Magnetically Dilute Powder Spectra. Chem. Phys. 1991, 151, 323-333.

(93) Boča, R. Zero-Field Splitting in Metal Complexes. Coord. Chem. Rev. 2004, 248, 757-815.

(94) Sanjeev, R.; Jagannasham, V.; Vrath, R. V. Implications of a Novel Interpretation of the Isosbestic Point. Chem. New Zeal. 2012, 76, 133-135.

(95) Royer, A. C.; Russell, K.; Belmore, K.; Vincent, J. B. Formation of Oxo-Centered Trinuclear Chromium Carboxylate Complexes and Hydrolysis of $\mathrm{Cr} 3$ as Established by Paramagnetic 2H NMR Spectroscopy. J. Inorg. Biochem. 2014, $131,12-20$.

(96) Turowski, P. N.; Bino, A.; Lippard, S. J. M-Hydroxobis(M-formato)Hexaaquadichromium(III), an Intermediate in the Formation of Basic Chromium Carboxylates. Angew. Chemie Int. Ed. English 1990, 29, 811-812.

(97) Brudenell, S. J.; Crimp, S. J.; Higgs, J. K. E.; Moubaraki, B.; Murray, K. S.; Spiccia, L. Binuclear Chromium (III) Complexes Bridge by Hydroxide and Acetate Groups. Inorganica Chim. Acta 1996, 247, 35-41.

(98) Spiccia, L.; Fallon, G. D.; Markiewicz, A.; Murray, K. S.; Riesen, H. Synthesis, Structure, and Spectral and Magnetic Properties of ( $\mu$-Carbonato $)(\mu-$ Hydroxo)Bis[N, N'-(Bis(2-Aminoethyl)Ethane-1, 2-Diamine)Chromium(III)] Perchlorate. Inorg. Chem. 1992, 31, 1066-1072. 
(99) Dolomanov, O. V.; Bourhis, L. J.; Gildea, R. J.; Howard, J. A. K.; Puschmann, H. OLEX2: A Complete Structure Solution, Refinement and Analysis Programo. $J$. Appl. Cryst. 2009, 42, 339-341.

(100) Sheldrick, G. M. SHELXT - Integrated Space-Group and Crystal-Structure Determination. Acta Cryst. A71 2015, 3-8.

(101) Sheldrick, G. M. Crystal Structure Refinement with SHELXL. Acta Cryst. C71 2015, 3-8.

(102) Yoshida, J.; Kondo, S.; Yuge, H. A Synthetic Strategy for a New Series of OxoCentered Tricobalt Complexes with Mixed Bridging Ligands of Acetate and Pyrazolate Anions. Dalton Trans. 2013, 42, 2406-2413.

(103) Overgaard, J.; Iversen, B. B.; Palii, S. P.; Timco, G. A.; Gerbeleu, N. V.; Larsen, F. K. Host-Guest Chemistry of the Chromium-Wheel Complex [Cr8F8(TBuCO2)16]: Prediction of Inclusion Capabilities by Using an Electrostatic Potential Distribution Determined by Modeling Synchrotron X-Ray Structure Factors at 16 K. Chem. - A Eur. J. 2002, 8, 2775-2786.

(104) Tomsa, A. R.; Li, Y.; Blanchard, S.; Herson, P.; Boubekeur, K.; Gouzerh, P.; Proust, A. Oxo-Centered Trinuclear Chromium(III) Complexes with Both Carboxylate and Amidoximate Ligands. J. Clust. Sci. 2014, 25, 825-838.

(105) Botezat, O.; Filippova, I. G.; Hauser, J.; Krämer, K.; Decurtins, S.; Liu, S.-X.; Baca, S. G. Synthesis, Crystal Structure, and Properties of a $\mu_{3}$-OxoTrichromium(III) Propionate Cluster with Pyrazole. J. Coord. Chem. 2015, 8972, $1-15$.

(106) Dong, J.; Liu, B.; Yang, B. Synthesis, Crystal Structure and Magnetic Properties of Trinuclear Chromium(III) Basic Carboxylate Assembly: [Cr3O(SalH)7(H2O)2] (SalH2=salicylic Acid), a New Member of [Cr3O] Family. J. Mol. Struct. 2016, 1116, 311-316.

(107) Xia, W.-S.; Radosevich, J.; Ellern, A. Triaqua- $\mu 3$-Oxo-Hexa- $\mu 2$-Propionato- $\kappa$ $12 \mathrm{O}$ : O '-Trichromium(III) Nitrate Hemihydrate. Acta Crystallogr. Sect. E 2006, $62,1213-1215$.

(108) Baranwal, B. P.; Fatma, T. Synthesis and Spectral Characterization of Novel OxoBridged, Thiocarboxylato Complexes of Chromium(III). Russ. J. Coord. Chem. 2006, 32, 824-829.

(109) Baranwal, B. P.; Fatma, T. Synthesis and Characterization of Oxo-Bridged, Trinuclear, Six-Coordinate Mixed-Carboxylato Complexes of Chromium (III). 2005.

(110) Glass, M. M.; Belmore, K.; Vincent, J. B. Nuclear Magnetic Resonance Studies of Multinuclear Chromium Assemblies. Polyhedron 1993, 12, 133-140. 
(111) Arafa, I. M.; Goff, H. M.; David, S. S.; Murch, B. P.; Que, L. Hydrogen and Deuterium NMR Studies of Carboxylate Coordination to Iron(III) Complexes: Diverse Chemical Shift Values for Coordinated Carboxyl Residues. Inorg. Chem. 1987, 26, 2779-2784.

(112) Kingry, K. F.; Royer, A. C.; Vincent, J. B. Nuclear Magnetic Resonance Studies of Chromium(III) Pyridinecarboxylate Complexes. J. Inorg. Biochem. 1998, 72, 7988.

(113) Ardizzoia, G. A.; Cenini, S.; La Monica, G.; Masciocchi, N.; Maspero, A.; Moret, M. Syntheses, Structures, and Reactivity of Polynuclear Pyrazolato Copper(I) Complexes, Including an Ab-Initio XRPD Study of [Cu(Dmnpz)](3) $(\mathrm{Hdmnpz}=$ 3,5-Dimethyl-4-Nitropyrazole). Inorg. Chem. 1998, 37, 4284-4292.

(114) Mccleverty, J. A.; Ward, M. D. The Role of Bridging Ligands in Controlling Electronic and Magnetic Properties in Polynuclear Complexes. Acc. Chem. Res. 1998, 31, 842-851.

(115) Ng, V. W. L.; Seah, L. K.; Weng, K. L.; Lip, L. K.; Geok, K. T.; Lai, Y. G.; Webster, R. D.; Kuan, S. L.; Leong, W. K.; Koh, L. L.; et al. Heterocyclic Thionates as a New Class of Bridging Ligands in Oxo-Centered Triangular Cyclopentadienylchromium(III) Complexes. Inorg. Chem. 2005, 44, 5229-5240.

(116) Cotton, F. A.; Wang, W. New Trinuclear, Oxo-Centered, Basic Carboxylate Compounds of Transition Metals. 1. Trichromium(II,III,III) Compounds. Inorg. Chem. 1982, 21, 2675-2678.

(117) Anson, C. E.; Bourke, J. P.; Cannon, R. D.; Jayasooriya, U. a; Molinier, M.; Powell, a K. Crystal Structures of the Isomorphous Prototypic Oxo-Centered Trinuclear Complexes [Cr3O $(\mathrm{OOCCH} 3)(6)(\mathrm{H} 2 \mathrm{O})(3)] \mathrm{Cl}$ Center Dot $6 \mathrm{H}(2) \mathrm{O}$ and $[\mathrm{Fe} 3 \mathrm{O}(\mathrm{OOCCH} 3)(6)(\mathrm{H} 2 \mathrm{O})(3)] \mathrm{Cl}$ Center Dot 6H(2)O. Inorg. Chem. 1997, 36, $1265-1267$.

(118) Mizuno, N.; Uchida, S. Structures and Sorption Properties of Ionic Crystals of Polyoxometalates with Macrocation. Chem. Lett. 2006, 35, 688-693.

(119) Mabbott, G. A. Introduction to Cyclic Voltammetry. J. Chem. Educ. 1983, 60, 697-702.

(120) Kissenger, P. T.; Heineman, W. R. Cyclic Voltammetry. J. Chem. Educ. 1983, 60, $702-706$.

(121) Létard, J.-F.; Guionneau, P.; Goux-Capes, L. Towards Spin Crossover Applications BT - Spin Crossover in Transition Metal Compounds III. In; Gütlich, P.; Goodwin, H. A., Eds.; Springer Berlin Heidelberg: Berlin, Heidelberg, 2004; pp. 221-249. 
(122) Glen, R. E. Descriptive Inorganic, Coordination, and Solid-State Chemistry; 2nd ed.; Thomson LEarning: Canada, 2002.

(123) Atmania, C.; Hajja, F. El; Benmansoura, S.; Marchiviea, M.; Trikia, S.; Conana, F.; Patineca, V.; Handela, H.; Dupouya, G.; Gómez-García, C. J. Guidelines to Design New Spin Crossover Materials. Coord. Chem. Rev. 2010, 254, 1559-1569.

(124) Chorazy, S.; Stanek, J. J.; Kobylarczyk, J.; Ohkoshi, S.; Siekluckaa, B.; Podgajny, R. Modulation of the FeII Spin Crossover Effect in the Pentadecanuclear $\{\mathrm{Fe} 9[\mathrm{M}(\mathrm{CN}) 8] 6\}(\mathrm{M}=\mathrm{Re}, \mathrm{W})$ Clusters by Facial Coordination of Tridentate Polyamine Ligands. Dalt. Trans. 2017, 46, 8027.

(125) Homenya, P.; Heyer, L.; Renz, F. Electromagnetic Radiation as a Spin Crossover Stimulus. Pure Appl. Chem2 2015, 87, 293-300.

(126) Ohkoshi S.; Imoto K.; Tsunobuchi Y.; Takano S.; Tokoro H. Light-Induced SpinCrossover Magnet. Nat. Chem 2011, 3, 564-569.

(127) Her, J. L.; Matsuda, Y. H.; Nakano, M.; Niwa, Y.; Inada, Y. Magnetic FieldInduced Spin-Crossover Transition in [MnIII(Taa)] Studied by x-Ray Absorption Spectroscopy. J. Appl. Phys. 2010, 111, 1-4.

(128) Wang, J.-L.; Liu, Q.; Lv, X.-J.; Duan, C.-Y.; Liu, T. Thermal and Light Induced Spin Crossover in a Mononuclear Iron(II) Complex. Inorg. Chem. Commun. 2017, $85,37-40$.

(129) Plieth, W.; Wilson, G. S.; Gutierrez De La Fe, C. Spectroelectrochemistry : A Survey of in Situ Spectroscopic Techniques. Pure Appl. Chem. 1998, 70, 13951414.

(130) Maresca, K. P.; Rose, D. J.; Zubieta, J. Synthesis and Characterization of a Binuclear Rhenium Nitropyrazole Complex [Re2O3Cl2(PPh3)2(C3H2N3O2)2]. Inorganica Chim. Acta 1997, 260, 83-88. 


\section{Appendix}

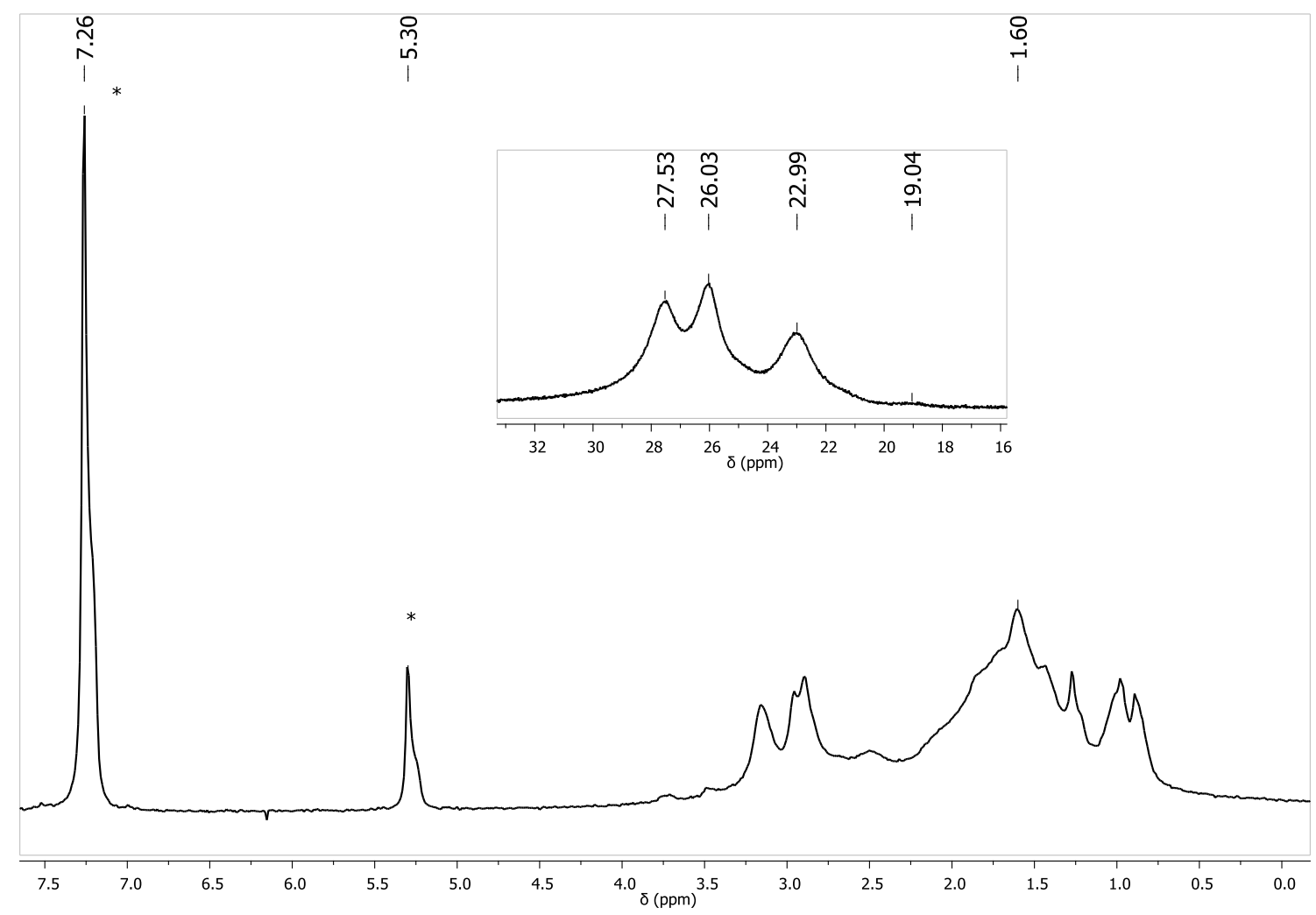

Figure A. $1{ }^{1} \mathrm{H}$ NMR of complex 14 in $\mathrm{CDCl}_{3}$ at $400 \mathrm{MHz}$. Spectra referenced to the residual solvent proton resonance. $(*=$ solvent residue) 


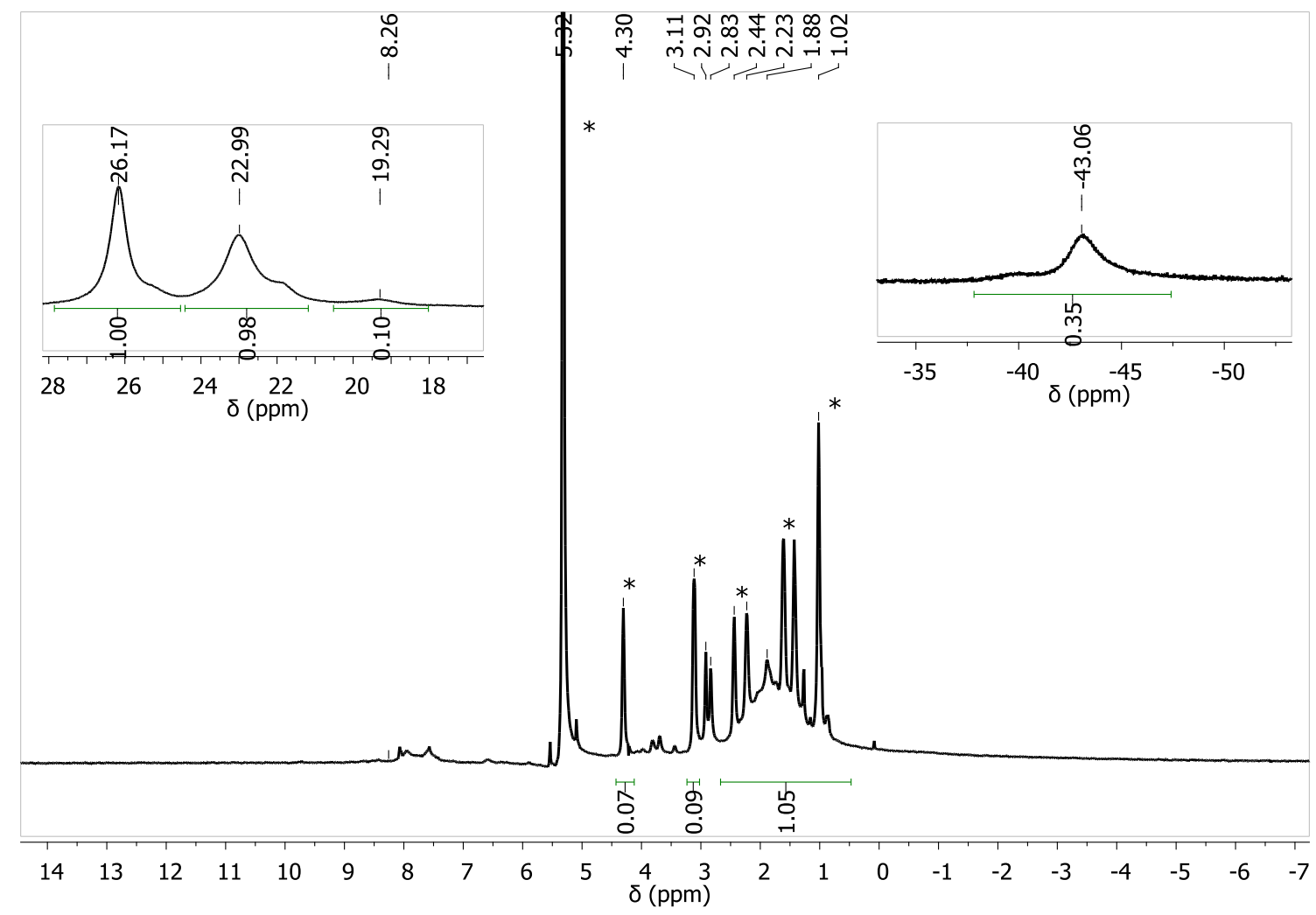

Figure A. $2{ }^{1} \mathrm{H}$ NMR of complex 15 in $\mathrm{CD}_{2} \mathrm{Cl}_{2}$ at $400 \mathrm{MHz}$. Spectra referenced to the residual solvent proton resonance. $(*=$ solvent residue or impurity) 


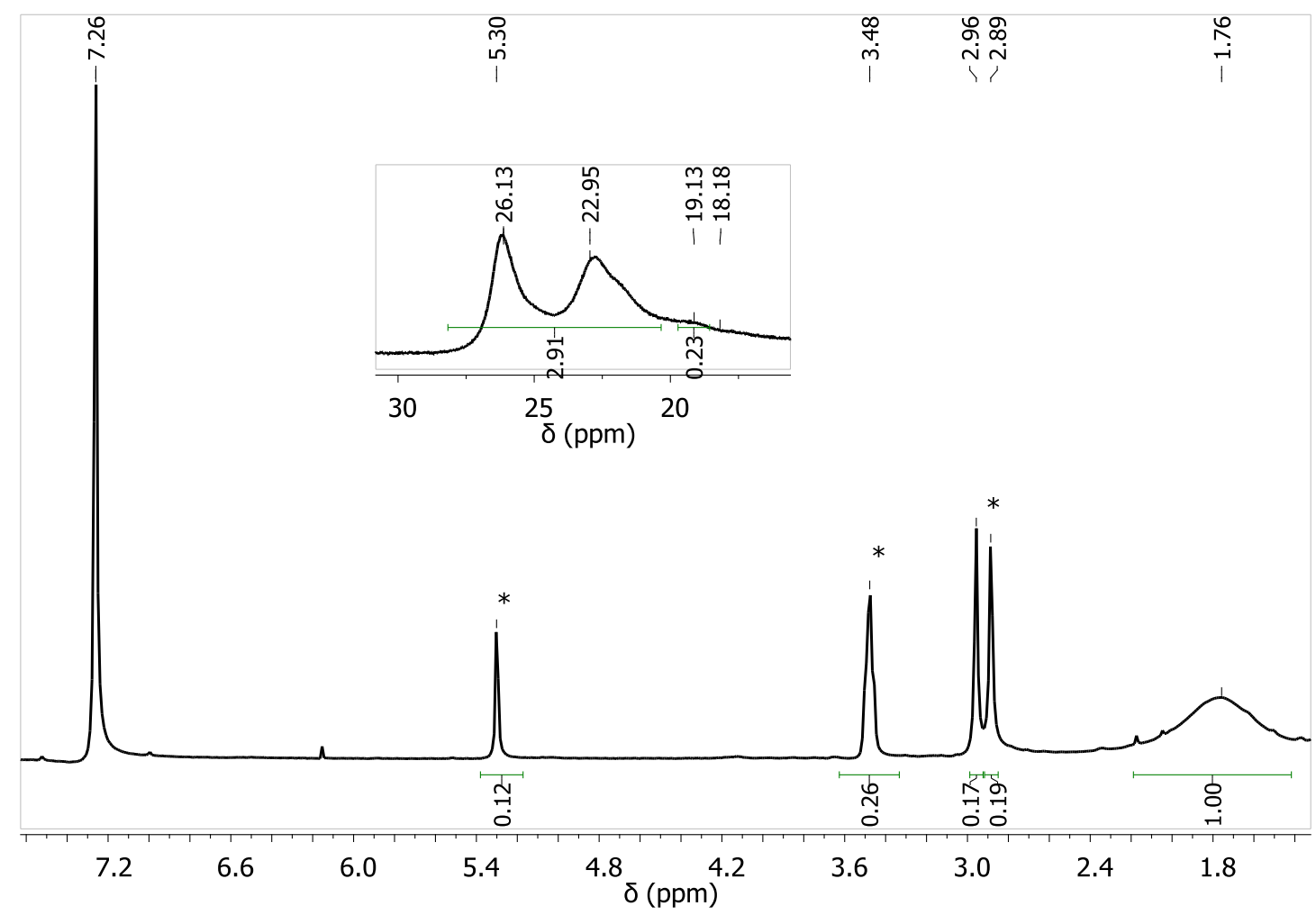

Figure A. $3{ }^{1} \mathrm{H}$ NMR of complex 16 in $\mathrm{CDCl}_{3}$ at $400 \mathrm{MHz}$. Spectra referenced to the residual solvent proton resonance. $(*=$ solvent residue or impurity) 


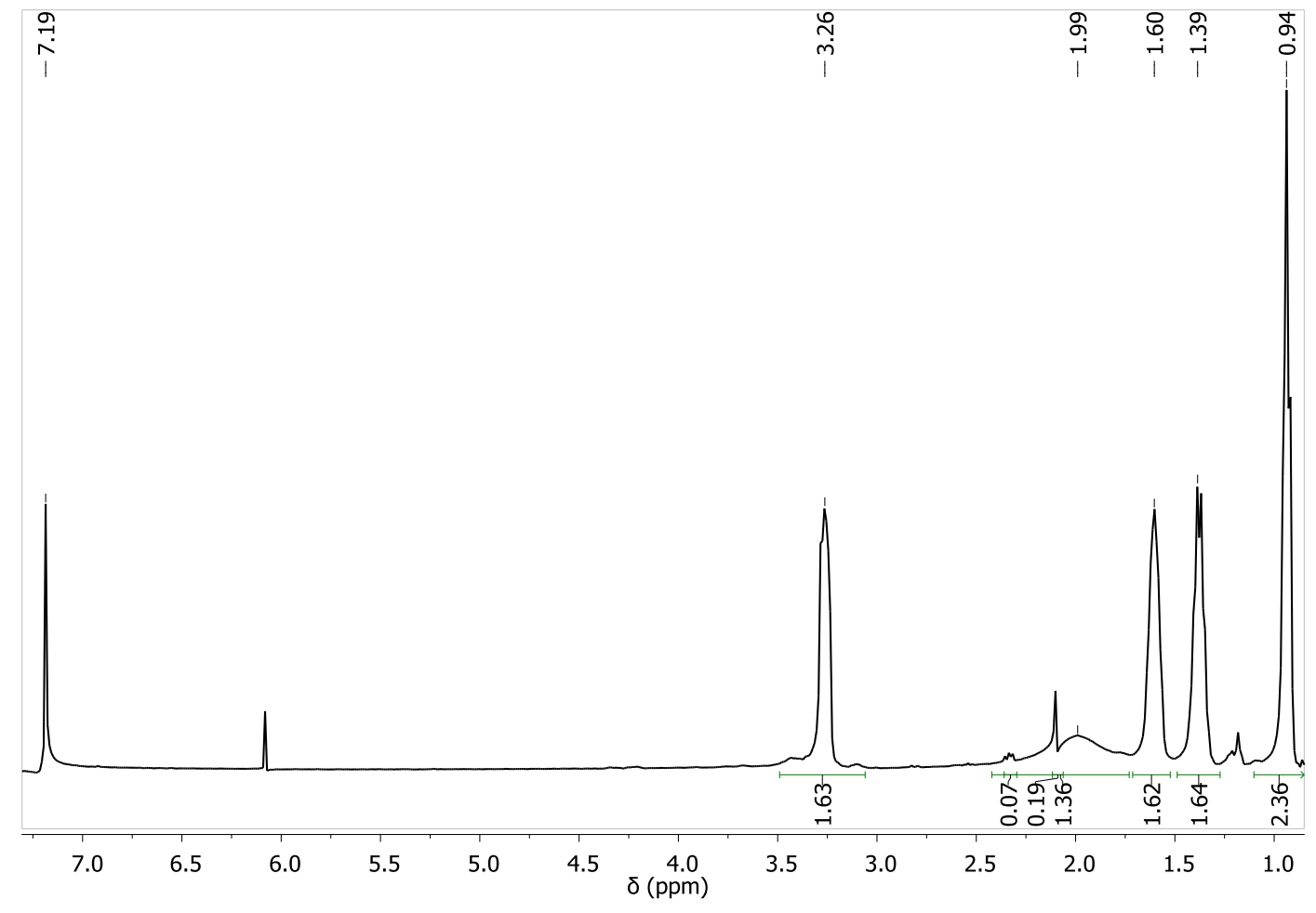

Figure A.4 $\mathrm{H}^{1} \mathrm{NMR}$ of reduction of 20. (400 MHz, $\mathrm{CDCl}_{3}$ ) 


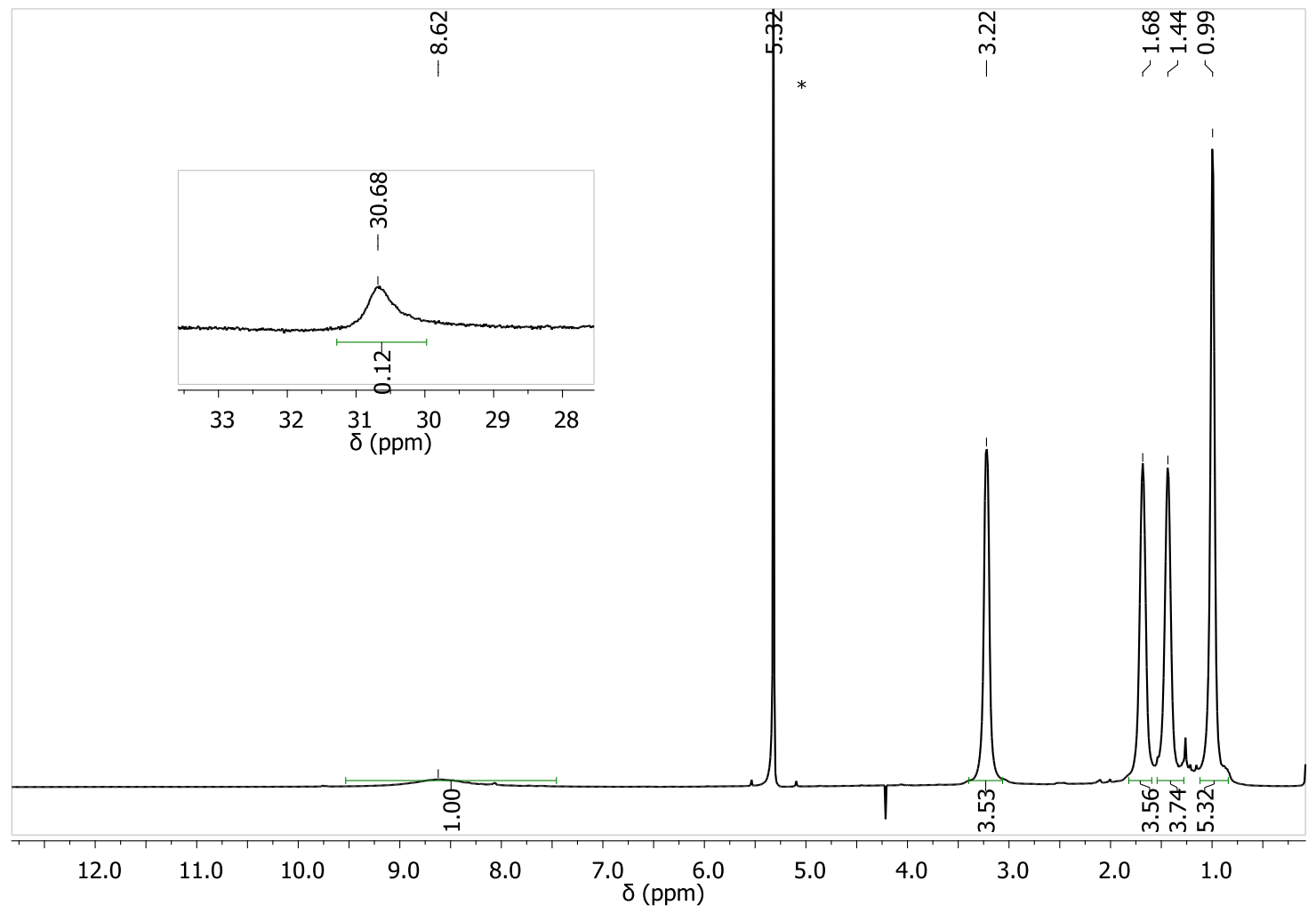

Figure A. $5 \mathrm{H}^{1} \mathrm{NMR}$ of oxidation of $20 .\left(400 \mathrm{MHz}, \mathrm{CD}_{2} \mathrm{Cl}_{2}\right)$ 
JESSICA MARIA LOPEZ PLA

$\begin{array}{ll} & \text { Born, Ceiba, Puerto Rico } \\ 2009 & \begin{array}{l}\text { Bachelor of Science in Industrial Chemistry } \\ \text { University of Puerto Rico } \\ \text { Humacao, PR, USA }\end{array} \\ & \\ 2010-2013 & \begin{array}{l}\text { Graduate teaching assistant } \\ \text { University of Puerto Rico - Río Piedras Campus } \\ \text { San Juan, PR, USA }\end{array} \\ & \text { Graduate teaching assistant } \\ 2013-2018 & \text { Florida International University } \\ & \text { Miami, FL } \\ 2015 & \text { Master of Science in Chemistry - Inorganic Chemistry } \\ & \text { Florida International University } \\ & \text { Miami, FL } \\ & \text { Doctoral Candidate } \\ & \text { Florida International University } \\ & \text { Miami, FL }\end{array}$

Selected Poster Presentations

- Jessica López Plá, Raphael G. Raptis. "Microwave assisted synthesis and characterization of Cr(III) pyrazolate-formate mixed ligand complexes", $92^{\text {nd }}$ Florida Annual Meeting and Exposition (FAME 2017), Florida Local Section of the ACS(FLACS), Tampa, FL, USA, May $4^{\text {th }}-6^{\text {th }}, 2017$.

- Jessica López Plá, Yesenia Vega, Raphael G. Raptis. "Synthesis and characterization of Pyrazolate-Supported $\mathrm{Fe}_{3}\left(\mu_{3}-\mathrm{O}\right)$ complexes and their redox properties", $93^{\text {rd }}$ Florida Annual Meeting and Exposition (FAME 2018), Florida Local Section of the ACS(FLACS), Tampa, FL, USA, May $3^{\text {rd }}-5^{\text {th }}, 2018$. 